\title{
Data Report for the Geologic and Scenic Quality Evaluation of Selected Sand and Gravel Sites on the Wind River Indian Reservation, Wyoming
}

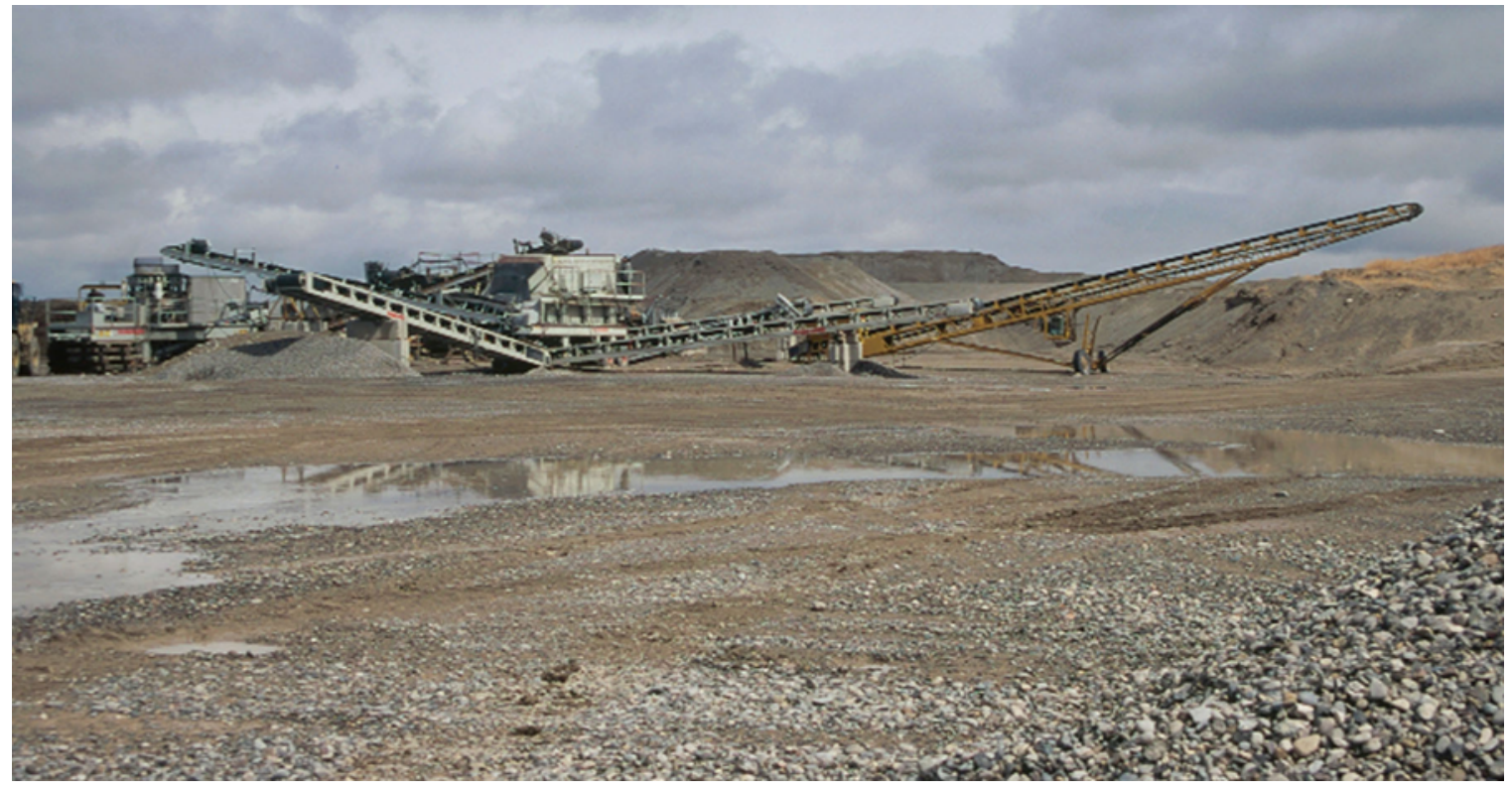

Open-File Report 2011-1302

U.S. Department of the Interior

U.S. Geological Survey 


\section{Data Report for the Geologic and Scenic Quality Evaluation of Selected Sand and Gravel Sites on the Wind River Indian Reservation, Wyoming}

By William H. Langer, Bradley S. Van Gosen, Belinda Arbogast, and David A. Lindsey

Open-File Report 2011-1302

U.S. Department of the Interior

U.S. Geological Survey 


\section{U.S. Department of the Interior KEN SALAZAR, Secretary}

\section{U.S. Geological Survey Marcia K. McNutt, Director}

U.S. Geological Survey, Reston, Virginia: 2011

For more information on the USGS-the Federal source for science about the Earth, its natural and living resources, natural hazards, and the environment, visit http://www.usgs.gov or call 1-888-ASK-USGS

For an overview of USGS information products, including maps, imagery, and publications, visit $h$ ttp://www.usgs.gov/pubprod

To order this and other USGS information products, visit http://store.usgs.gov

Any use of trade, product, or firm names is for descriptive purposes only and does not imply endorsement by the U.S. Government.

Although this report is in the public domain, permission must be secured from the individual copyright owners to reproduce any copyrighted materials contained within this report.

Suggested citation:

Langer, W.H., Van Gosen, B.S., Arbogast, Belinda, and Lindsey D.A., 2011, Data report for the geologic and scenic quality evaluation of selected sand and gravel sites on the Wind River Indian Reservation, Wyoming: U.S. Geological Survey Open-File Report 2011-1302, $158 \mathrm{p}$. 


\section{Executive Summary}

This data report contains the results for 12 sites investigated in April 2005 on the Wind River Indian Reservation, Wyoming, including:

- The U.S. Geological Survey (USGS) geologic studies and engineering tests.

- A conclusion and suggestions for the best use of sand and gravel materials.

- Calculations of available sand and gravel materials.

- A scenic quality landscape inventory and evaluation.

- A digital dataset of sand and gravel deposits on the Wind River Indian Reservation, Wyoming.

Appendix 1 contains the detailed information mentioned above for each site. Appendix 2 contains the photographic documentation that represents the scenic quality of each site. Appendix 3 contains the engineering test results from Inberg-Miller Engineers, Riverton, Wyoming.

The text of this report is presented in a Portable Document Format (pdf). Adobe Acrobat Reader or similar software is required to view it. The digital dataset is presented as a shapefile. Suitable GIS or CAD software is required to view it.

\section{Geologic Quality}

For this assessment, the estimates of the quantity and quality of aggregate resources are based largely on a generalized knowledge of the geologic character of the deposits and on limited engineering tests. Our estimates were based on an assumed continuity of materials made by comparing the geologic characteristics of the unknown parts of the deposit against other similar, better understood, parts of the deposit such as observations made in gravel pits or exposed edges of the terraces. It is recommended that a detailed examination of any deposit be made before developing a large-scale commercial operation on that deposit.

Sources of sand and gravel were evaluated regarding their potential for use as aggregate in Portland cement concrete, asphalt, and base course. All deposits evaluated generally meet the requirements for these three uses. Gravel from all the deposits will have to be crushed and screened if used for asphaltic concrete, and oversized gravel will have to be crushed and screened for use in Portland cement concrete. The final product may require washing for certain high-specification uses.

All deposits evaluated contain coatings of caliche (calcium carbonate- $\mathrm{CaCO}_{3}$ ), which may cement the particles. Some deposits contain large boulders. These factors may complicate the extraction and processing of sand and gravel. 
There is a special consideration regarding the use of Wind River terrace gravels for aggregate in Portland cement concrete. Certain varieties of quartz minerals present in rocks throughout the region are susceptible to the alkali-silica reaction (ASR) when used in Portland cement concrete. All the deposits evaluated contain potentially reactive quartz minerals.

\begin{tabular}{l|l|l|l|l}
\hline Evaluation & $\begin{array}{l}\text { Generally } \\
\text { Factors } \\
\text { suitable for use } \\
\text { as Portland } \\
\text { cement concrete, } \\
\text { asphalt, and base }\end{array}$ & $\begin{array}{l}\text { Thickness of } \\
\text { caliche may } \\
\text { complicate } \\
\text { excavation and } \\
\text { processing }\end{array}$ & $\begin{array}{l}\text { Presence of } \\
\text { large boulders } \\
\text { may complicate } \\
\text { excavation and } \\
\text { processing }\end{array}$ & $\begin{array}{l}\text { Increased } \\
\text { concern for } \\
\text { alkali-silica } \\
\text { reaction potential }\end{array}$ \\
\hline Site Name & $\begin{array}{l}\text { All evaluated } \\
\text { sites }\end{array}$ & $\begin{array}{l}\text { Airport } \\
\text { Kane Draw } \\
\text { Winkleman Dome } \\
\text { Willow Creek }\end{array}$ & $\begin{array}{l}\text { Red Rocks } \\
\text { Kane Draw } \\
\text { Kinear } \\
\text { Winkleman } \\
\text { Dome }\end{array}$ & $\begin{array}{l}\text { Winkleman } \\
\text { Dome }\end{array}$ \\
\hline
\end{tabular}

\section{Scenic Quality}

For this assessment, the scenic quality inventory focuses on features that occur naturally in the landscape and ranking proposed sites. The rankings can be used as a guide to analyze potential visual impacts of sand and gravel development at each site.

Information collected for this scenic quality classification indicates that two of the Wind River Indian Reservation sites are classified with a scenic quality rating of A (highest), four sites are rated B (moderate), and six sites are rated C (lowest). Scenic quality ratings are listed below for each site.

\begin{tabular}{l|l|l|l}
\hline $\begin{array}{l}\text { Scenic Qualty } \\
\text { Rating }\end{array}$ & \multicolumn{1}{|c}{ A } & \multicolumn{1}{c}{ B } & \multicolumn{1}{c}{ C } \\
\hline Site Name & $\begin{array}{l}\text { Red Rocks } \\
\text { Willow Creek }\end{array}$ & $\begin{array}{l}\text { Burma Hill } \\
\text { Crowheart Butte \#1 } \\
\text { Kane Draw } \\
\text { Le Clair }\end{array}$ & $\begin{array}{l}\text { Airport } \\
\text { E Boysen Causeway } \\
\text { Johnstown } \\
\text { Kinnear } \\
\text { Sheer } \\
\text { Winkleman Dome }\end{array}$ \\
\hline
\end{tabular}




\section{Contents}

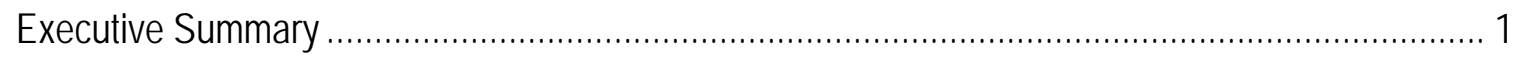

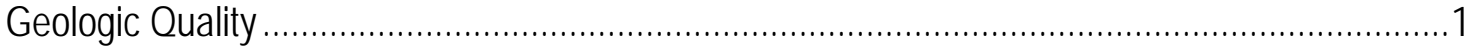

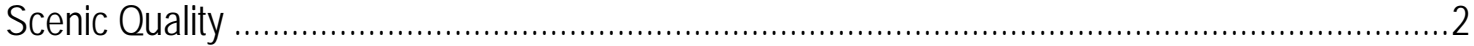

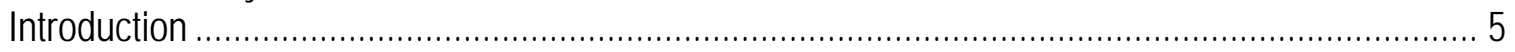

Acknowledgments .................................................................................................. 5

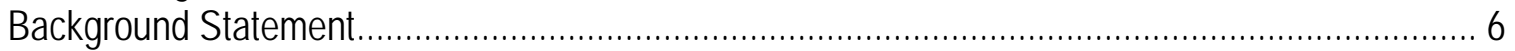

General Geology and Resources of the Wind River Indian Reservation...................................... 8

Geology of the Sand and Gravel Resources in River Terraces .............................................

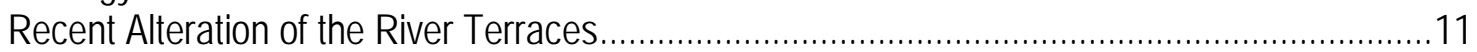

Geologic Investigations and Engineering Tests .............................................................12

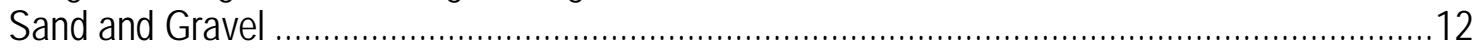

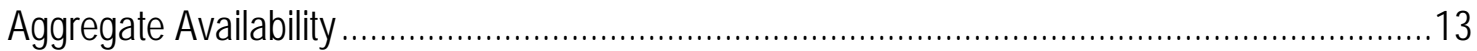

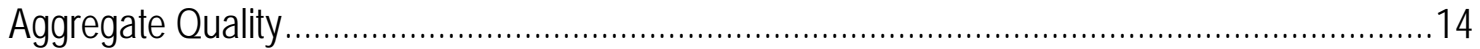

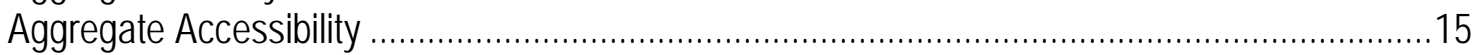

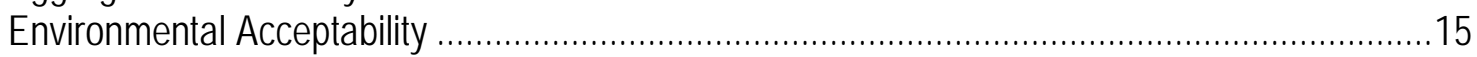

Scenic Quality Inventory ...............................................................................................16

Landform in the Wind River Reservation ....................................................................16

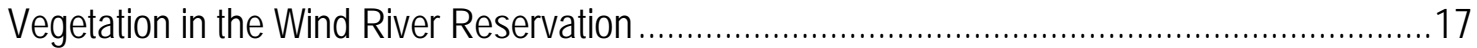

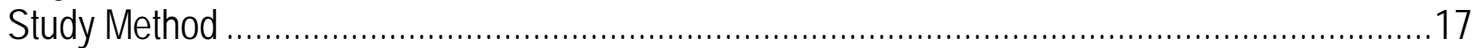

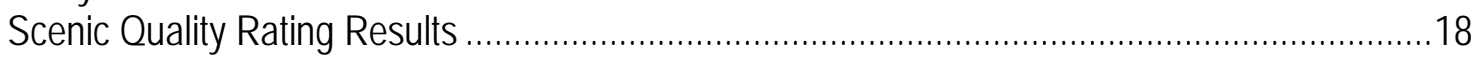

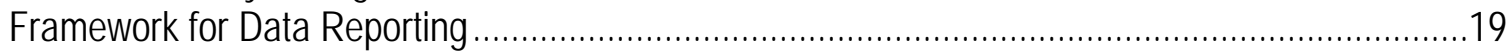

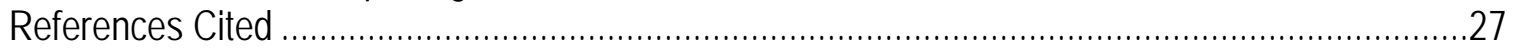

Glossary .................................................................................................................

Appendix A-Data Sheets Describing Geologic, Engineering, and Visual Assessment Observations

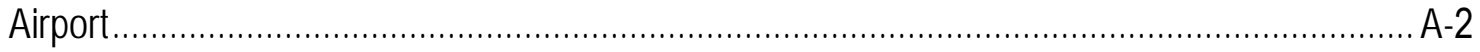

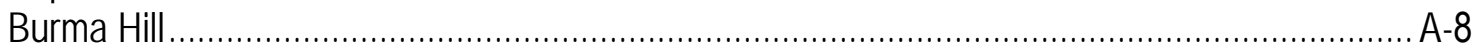

Crowheart Butte \#1

East Boysen Causeway ...................................................................................... A

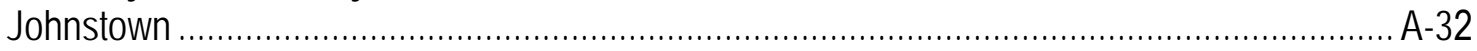

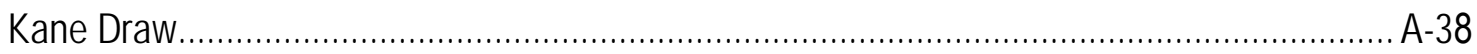

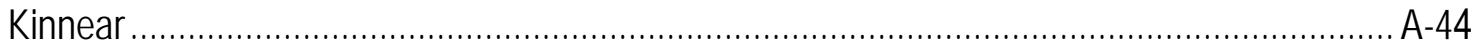

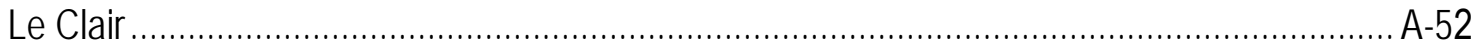

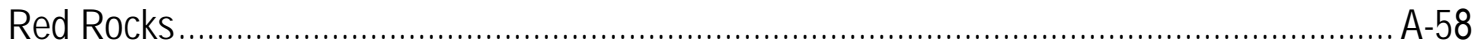

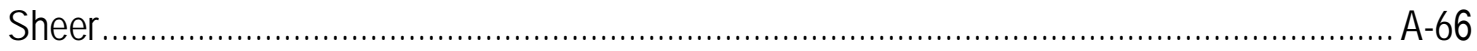

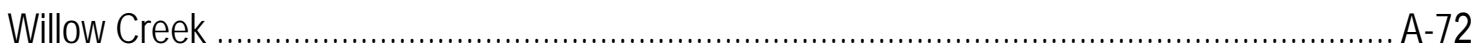

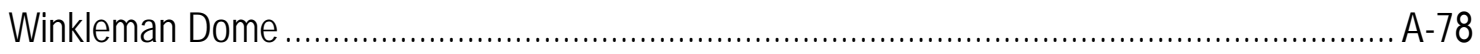

Appendix B-Photographic Documentation Representing Scenic Quality of Each Site

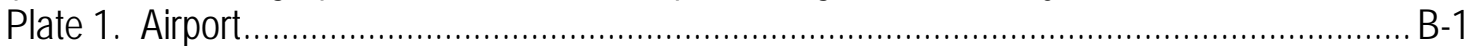

Plate 2. Burma Hill .........................................................................................

Plate 3. Crowheart Butte \#1 …….....................................................................

Plate 4. East Boysen Causeway ........................................................................ B-4

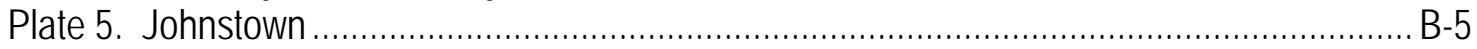

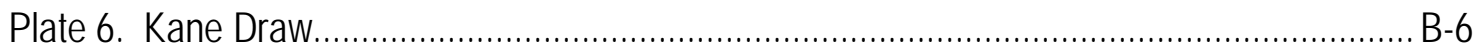

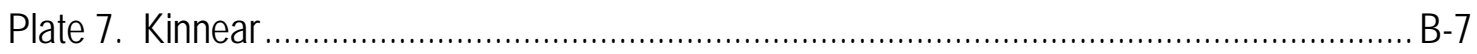

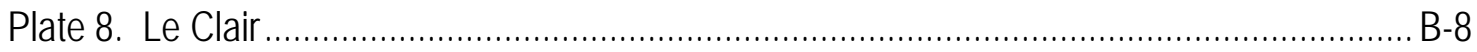




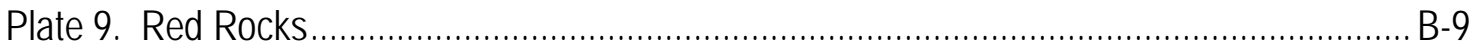

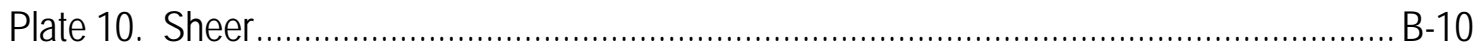

Plate 11. Willow Creek ............................................................................................... B-11

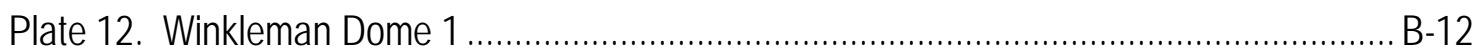

Plate 13. Winkleman Dome 2 ..................................................................................... B-13

Appendix C_Engineering Test Results from Inberg-Miller Engineers

Appendix D_Digital Dataset of Sand and Gravel Deposits on the Wind River Indian Reservation, Wyoming

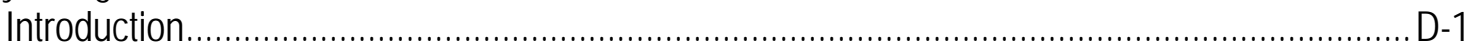

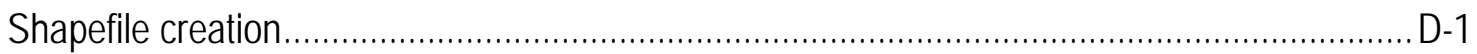

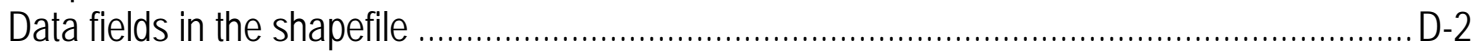

\section{Figures}

1. Map of the Wind River Indian Reservation (grey shaded area) with site locations...............7

2. The Wind River Reservation (outlined in black) features include the Wind River Basin, three mountain ranges in a general north-south direction, and the Wind River....................8

3. The prominent flat terrace tops (black arrows point to the treads) and gently sloping terrain with mountain backdrop compose a typical Wind River Indian Reservation landscape.

4. Geologist taking sample from pit face using a technique referred to as vertical trenching

5. Geologist dividing a large bulk sample using a technique referred to as "cone and quartering.

\section{Tables}

1. Sand and gravel sold or used by producers, and number of active sand and gravel operations in Wyoming................................................................................. 12

2. Construction sand and gravel sold or used in Wyoming in 2002 , by major use category...13

3. Scenic quality rating summary for 13 field sites in the Wind River Indian Reservation.......19

4. Framework for data reporting sand and gravel studies on the Wind River Indian Reservation 


\section{Introduction}

During April 2005, the U.S. Geological Survey (USGS) conducted field work on the Wind River Indian Reservation, Wyoming, to inventory and evaluate sand and gravel deposits underlying river terraces on tribal lands along the Wind River. The geologic approach conducted by the USGS places the results of previous and current engineering tests in a context more useful to the tribes, which will allow them to take advantage of a wealth of existing technical data. A scenic quality inventory was conducted simultaneously in order for the tribes to evaluate some of the visual impacts of developing aggregate resources. This document consists of two major products: (1) a report of the field study undertaken by the USGS for this project, and (2) a dataset of sand and gravel deposits on the Wind River Indian Reservation, Wyoming.

This report is structured primarily for the reader who starts with no knowledge of geology or landscape assessment. It also provides an accessible source of information for the geologist or land planner.

The specific objectives are several. One objective is to provide a geologic description for each site including the deposit location, geologic observations on sand and gravel deposits such as gravel rock type, particle roundness, general condition of the particles, overburden, deposit thickness, deleterious minerals, and river-terrace level.

A second objective is to provide engineering tests including gradation, Los Angeles (LA) abrasion, soundness, specific gravity, and absorption on 14 samples from 12 sites on tribal lands or on allotment land. The samples were delivered to a certified engineering laboratory for testing and the results are included in Appendix 3.

A third objective is to document and rate the scenic quality of the sites investigated in the project area. This includes a scenic quality field inventory, score, and classification. The purpose of the scenic quality inventory is to establish a consistent database describing the inherent scenic values of the natural landscape.

\section{Acknowledgments}

The USGS would like to thank Floyd Phillips, Bureau of Indian Affairs; Ed Womack, Bureau of Land Management; and John Enos, Shoshone Oil and Gas Commission, for their cooperation and help in undertaking this project. 


\section{Background Statement}

The U.S. Bureau of Land Management (BLM) solicited the USGS to conduct an evaluation of some of the gravel resources on the Wind River Indian Reservation, Wyo. The Wind River Indian Reservation is located in central Wyoming and includes portions of Fremont and Hot Springs counties. The reservation occupies about 3,500 square miles just east of the Continental Divide and is home of two Tribes, the Eastern Band of the Shoshones and the Northern Band of the Arapaho.

Currently, a number of active, inactive, and abandoned mines could be re-opened to provide sand and gravel. This would make better use of existing resources where disturbance has already occurred. After discussions with the BLM, it was agreed that the USGS would conduct a traditional geologic investigation of 12 sand and gravel deposits, and have engineering testing conducted on samples from those sites. The sites include: Airport, Burma Hill, Crowheart Butte \#1, East Boysen Causeway, Johnstown, Kane Draw, Kinnear, Le Clair, Sheer, Red Rocks, Willow Creek, and Winkleman Dome (fig. 1).

Landscape has many definitions. For the purpose of this report, it is the visual setting that deals with perception. It consists of the space surrounding the observer and what can be seen of a site from a point within or from a travel route (pedestrian or vehicular). Visual resource management is a program to identify and protect visual values of landscapes.

Mineral development, if not carefully planned, has the potential to modify the character of the landscape and create visual impacts. The development of proposed sand and gravel operations in the Wind River Reservation could affect visual resources and visual quality within the project area. It was therefore also agreed that the USGS would conduct scenic quality landscape evaluations as part of the field work. One premise is that visual (scenic) attractiveness is related to the essential character of a landscape. Landscape character, according to the Bureau of Land Management, (1986) includes three key factors: (1) landform/water; (2) vegetation; and (3) structure (human-made features of the landscape); each of which is described in terms of form, line, color, and texture. Resource managers, including the U.S. Forest Service and BLM, recognize a scenic quality evaluation of the visual landscape is not a stand-alone item, but is one part of a larger integrated program with other biological, physical, and social/cultural resources. An evaluation of the visual contrast which would occur between the existing landscape and the proposed project, and, if necessary, measures to reduce this contrast (and thus minimize adverse visual impacts) could be undertaken.

After a meeting with the BLM, the Bureau of Indian Affairs, and a representative from the Shoshone and Arapaho Tribes, it was agreed that the USGS would inventory and evaluate the sand and gravel deposits underlying river terraces on tribal lands along the Wind River and would provide: (1) a data report and (2) a dataset of sand and gravel deposits on the Wind River Indian Reservation, Wyoming. 
During April, 2005, fieldwork was undertaken to evaluate the sand and gravel resources on the Wind River Reservation. The field party consisted of geologists, Bill Langer (Contact Person, USGS, MS 973, BOX 25046, Denver, Colorado, 80225, Tel: 303-236-1249, email: blanger@usgs.gov), Brad Van Gosen, Dave Lindsey, and landscape architect Belinda Arbogast. Access to study area was along unimproved roads by four-wheel-drive vehicle or by walking.

This report was originally transmitted to the Bureau of Land Management as an Administrative report in January, 2006. Tables 1 and 2 have been updated since that original transmittal.

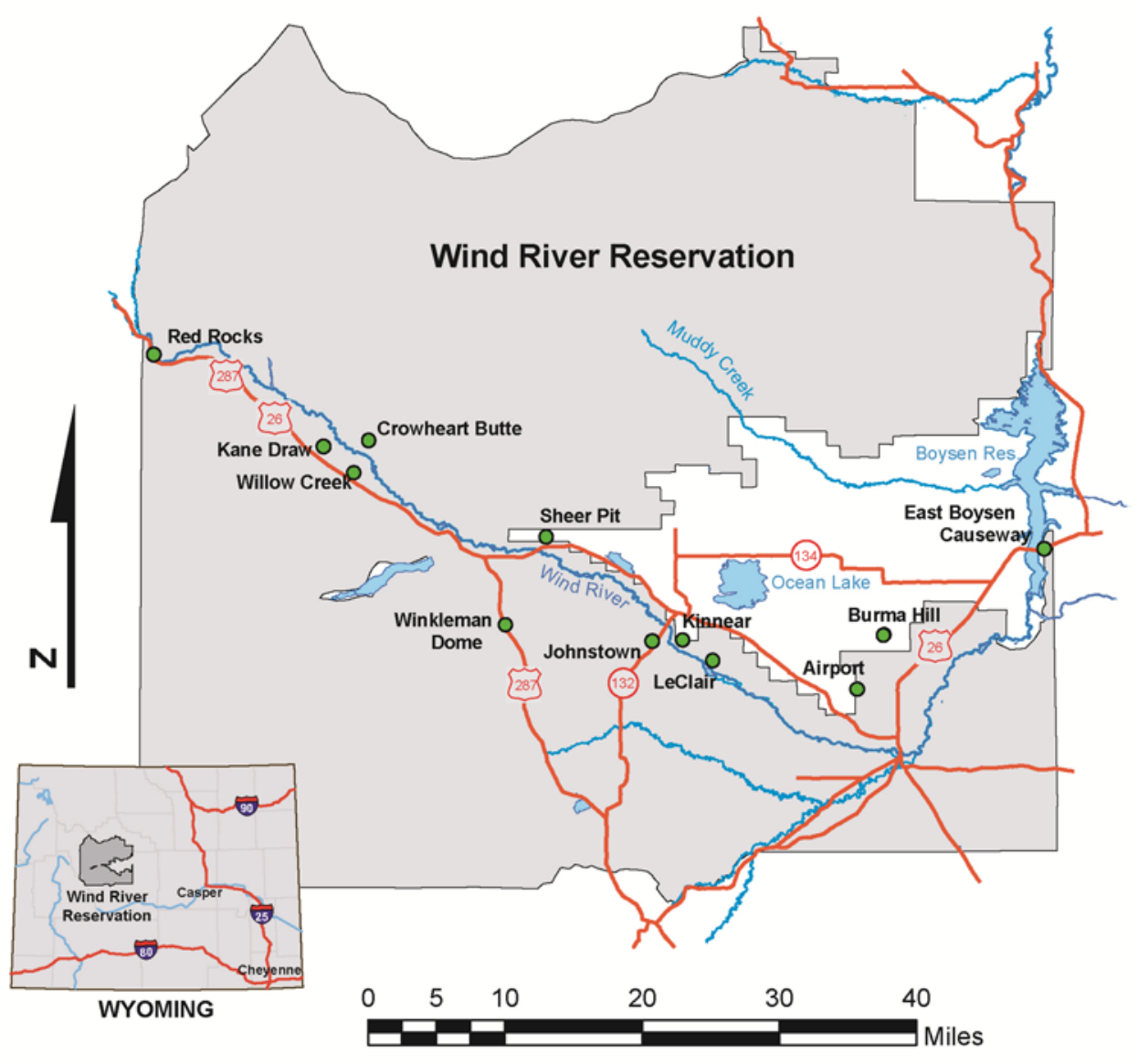

Figure 1. Map of the Wind River Reservation (grey shaded area) and site locations. 


\section{General Geology and Resources of the Wind River Indian Reservation}

The Wind River Indian Reservation lies in a complex structural setting that includes a large inter-mountain depositional basin — the Wind River Basin—bordered by large Rocky Mountain uplifts: the Wind River Range, the Absaroka Range, and the Owl Creek Mountains (fig. 2). During the Laramide Orogeny of North America, large faults along the mountain-basin boundaries offset rocks that formed earlier in the Precambrian, Paleozoic, and Mesozoic geologic eras, moving the rock units upward at least 39,000 feet (ft) (12 kilometers (km)) to form the Wind River Range and Owl Creek Mountains and adjacent Wind River Basin (Keefer, 1965a, 1965b; Keefer and Van Lieu, 1966; Willis and Groshong, 1993). Rocks now exposed in the mountains and their flanks include representatives of each of the major time periods: Precambrian, Paleozoic, Mesozoic, and Cenozoic eras. Only rocks of the Silurian time period are missing (Keefer and Van Lieu, 1966; McGreevy and others, 1969). The Precambrian-age rocks are primarily igneous intrusions and metamorphic rocks, while the overlying Paleozoic and Mesozoic rocks are layers of sedimentary rocks, including dolomite, limestone, sandstone, conglomerate, siltstone, and shale.

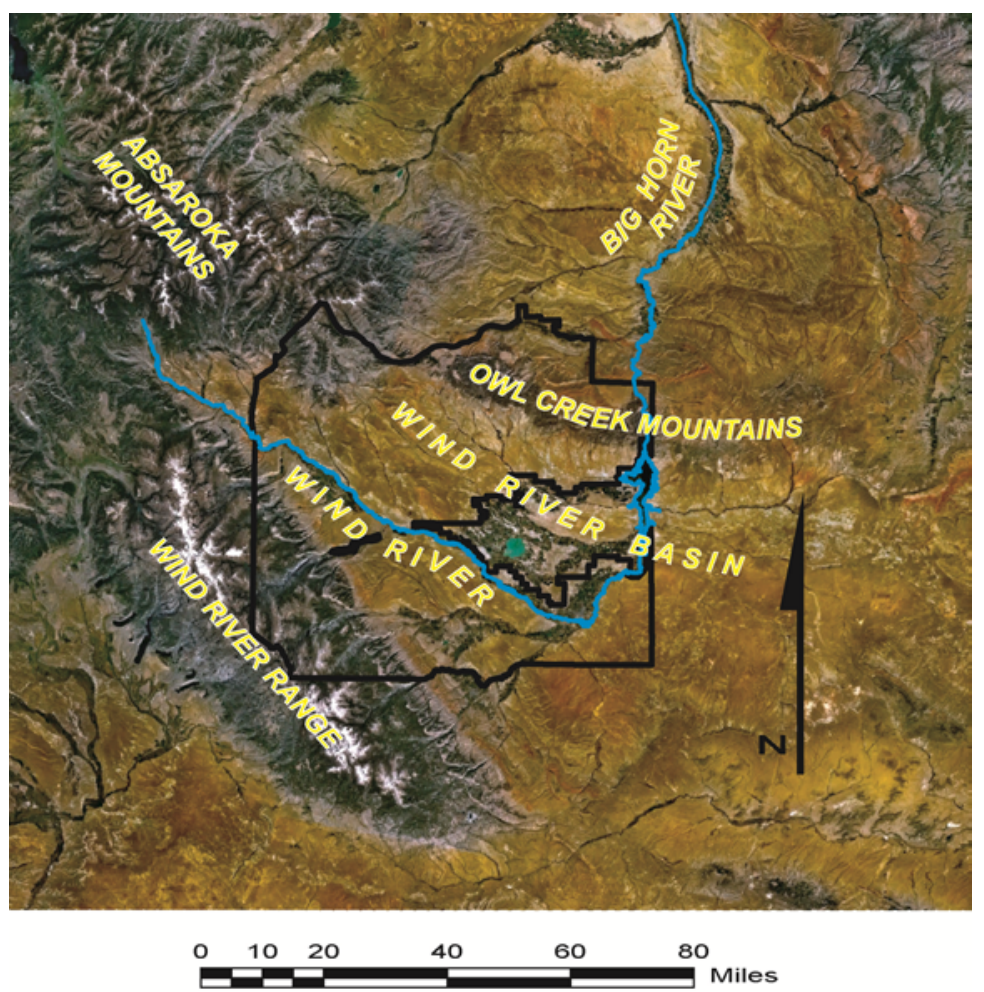

Figure 2. The Wind River Reservation (outlined in black) features include the Wind River Basin, three mountain ranges in a general north-south direction, and the Wind River. The Wind River becomes the Big Horn River just a few miles north of the reservation. 
The majority of the exposed rocks in the center of the Wind River Basin are those of the Wind River Formation (lower Eocene in age), which consists primarily of sandstone, conglomerate, siltstone, and shale (McGreevy and others, 1969, plate 2). The Wind River Formation is covered locally by Cenozoic age deposits of glaciers, ancient river terraces, landslides, slope wash and alluvium. Tertiary-age volcanic rocks are the dominant rock type of the Absaroka Range in the northwestern region of the Reservation.

Considerable energy resources are hosted by the Wind River Basin in the Reservation. Dome-like folds in the sedimentary layers trap numerous reservoirs of petroleum and natural gas, which continue to supply productive wells for several oil fields within the Reservation (Keefer and others, 1993). Coal beds underlie about half of the Reservation (Peterson, 1993) and potential coalbed methane resources also exist (Johnson and Flores, 1993; Johnson and others, 1993).

The varied geology of the Wind River Reservation also contains a number of nonmetallic mineral resources with potential for development. Sand and gravel resources occur in glacial deposits, slope wash, river terraces, and recent alluvium. Sand and gravel resources are especially plentiful within the large river terrace deposits in the basin, which are discussed below. Rock strata that contain bentonite, gypsum, phosphate rock, clay, dolomite, limestone, granite, pumicite, sandstone, and shale exist within the Reservation (Gersic, 1993). Development of these industrial minerals would depend on effective marketing, likely to local industries and users.

For an overview of the geologic rock units and a geologic map of the Reservation the reader is referred to McGreevy and others (1969). The geologic history of this area is described by Keefer (1965b).

\section{Geology of the Sand and Gravel Resources in River Terraces}

The Wind River Basin, including the Wind River Indian Reservation, contains considerable sand and gravel resources suitable for multiple uses as aggregate. These sand and gravel resources lie mainly in terraces of the ancient Wind River and its tributaries. The terraces were deposited as the rivers migrated across and cut downward into the basin over approximately the last 1,700,000 years (Chadwick and others, 1997). Cobbles, gravel, sand, and silt were moved by the rivers during high water flow events and deposited as terrace deposits adjacent to each river in their floodplain. As a result, the terraces contain mixtures of sand, cobbles, and gravel composed of various rock types that came from the surrounding upstream region. The terraces, typically capped by cobble, gravel, and sand deposits, now lie well above the present Wind River in the form of broad, gently dipping slopes bounded by bench or step-like ledges, or isolated remnants, such as buttes or flattish ridges, which were left behind by the erosion of the surrounding land (fig. 3). 


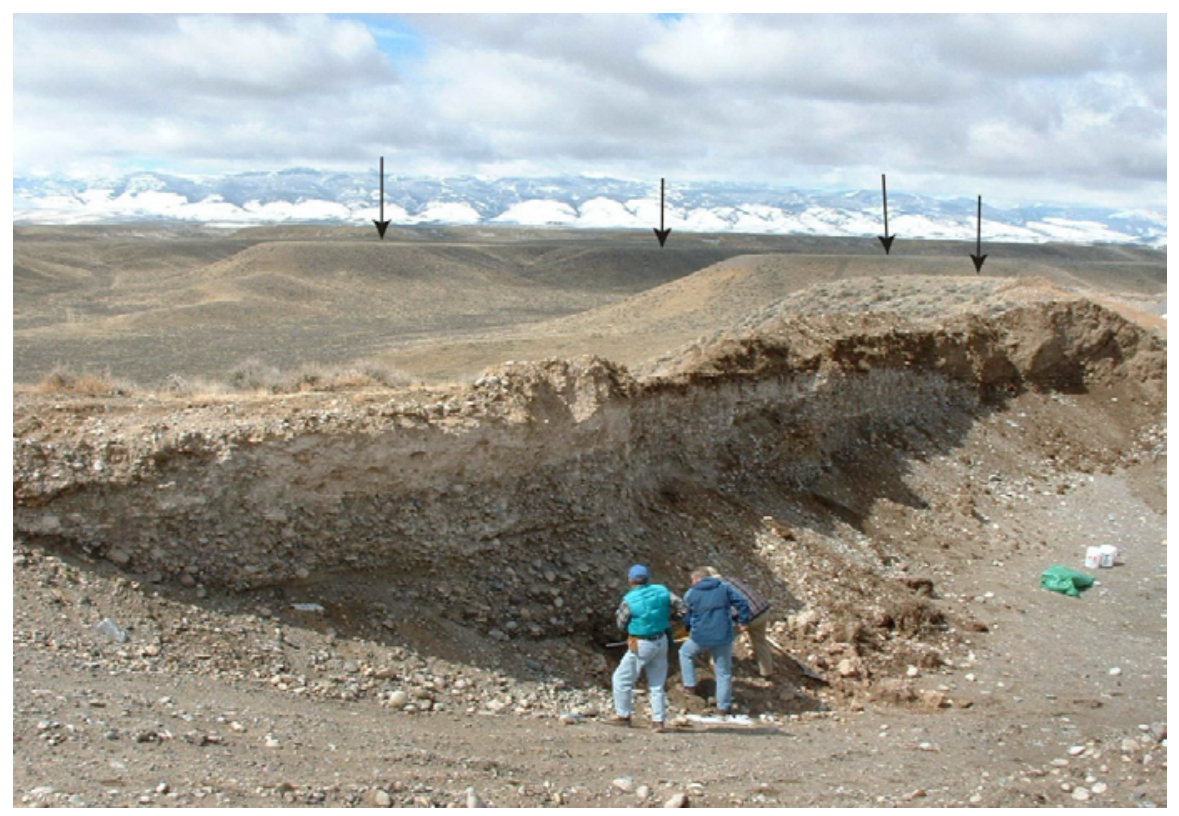

Figure 3. The prominent flat terrace tops (black arrows point to the treads) and gently sloping terrain with mountain backdrop compose a typical Wind River Indian Reservation landscape. At Winkleman Dome, USGS staff examines the exposed terrace scarp for geologic information concerning the sand and gravel. Photograph courtesy of Floyd Phillips.

The cobble-gravel-sand-silt deposits that cap the terraces in the Wind River Basin can be over $20 \mathrm{ft}$ thick, but typically range from about 12 to15 ft thick. The rock types found in the cobbles and gravel include sedimentary rocks derived from erosion of the basin, as well as sedimentary, igneous, and metamorphic rocks supplied by erosion of the mountain ranges that surround the basin (such as the Wind River and Absaroka Ranges and the Owl Creek Mountains). As a result, a wide variety of rock types (lithologies) are found in the terrace deposits, such as: (1) sedimentary rocks (sandstone, limestone, dolostone, and chert); (2) igneous rocks (volcanic rocks, granitic rocks, and dark magnesium-iron-rich (mafic) plutonic rocks); and (3) metamorphic rocks (granitic gneiss, mafic gneiss, quartzite, and quartz-rich veins).

At least a dozen terrace levels are preserved in the Wind River Basin, indicating a dozen or more major elevation levels for the Wind River and its tributaries as they eroded down into the basin (Morris and others, 1959; Chadwick and others, 1997). The terraces are arranged vertically in a step-wise manner with a stratigraphy that is counter intuitive to the arrangement of most sedimentary deposits (typically the oldest deposits lie at the bottom of the pile, youngest at the top). Rather, the down cutting rivers left the oldest individual terraces to rest at the highest elevations in the basin, while the lower terraces are progressively younger and younger as they step down towards the banks of the current Wind River that lies in the low points of the basin.

In addition to the Wind River and its tributaries, glaciers provided an important source of the rock material supplied to the basin and the river terraces. Glaciers of 
considerable size extended down from the Wind River Range into the western flanks of the basin during the Pleistocene glacial periods that affected North America. The remaining glacial deposits are well displayed near Bull Lake and northwestward for about 24 miles to the Dinwoody Lakes area (Richmond, 1964, 1965; Murphy and Richmond, 1965; Richmond and Murphy, 1965, 1989; McGreevy and others, 1969; Dahms and others, 2003, and references cited in Dahms and others, 2003). The glacial deposits of this area are classic remains of the glacial events in the Rocky Mountain region referred to as the Bull Lake (23,000-16,000 years before present) and Pinedale (>130,000-95,000 years before present) glacial advances (Chadwick and others, 1997).

These glacial events likely had much influence on the development of the river terraces in Wind River Basin over the last 130,000 years or more, such as: (1) the glaciers contributed significant rock debris and sediment loads to the basin, which were redistributed by the rivers and re-deposited as terraces; (2) the glaciers likely influenced the course and base level for the rivers in the area; and (3) retreat and melting of the glaciers during the late Pleistocene supplied significant water and additional sediment to the rivers in the basin.

\section{Recent Alteration of the River Terraces}

After the river terraces were deposited and left exposed, three primary processes affected their surfaces—soil development, weathering, and caliche formation.

Soil development within the upper intervals of the terraces ranges from negligible to several feet in thickness. The soil formation on each terrace was controlled by several factors that can vary from site to site, including local climate, elevation, exposure, drainage, and the primary rock types within the deposit (see Shroba, 1989). The soil horizon in the uppermost parts of the terrace, primarily a silt-clay-sand mixture, is usually considered a waste material that is removed and stored for later use in an aggregate mining operation (such as in site reclamation).

Following deposition, terrace deposits are subjected to natural weathering processes including physical weathering such as wetting, drying, freezing, thawing, and chemical weathering by acids dissolved in water percolating through the soil. Weathering processes can weaken some gravel particles, particularly granite, gneiss, and some volcanic gravels. Weathering processes can produce some deleterious materials including clays, which are altered feldspar minerals from granite and gneiss, or mica flakes, which remain after granite and gneiss is weathered. The degree of weathering of granite and volcanic clasts was observed and recorded in the field as part of this study.

Caliche is a calcium carbonate material $\left(\mathrm{CaCO}_{3}\right)$ similar in character and appearance to whitish cement, which commonly forms coatings and weak cement within the uppermost several feet of the sand-gravel-cobble terrace deposits in the Wind River Basin. During relatively dry climate cycles, precipitation can leach calcium from the soil and rocks in the ground (see Machette, 1985). Carbonate ions are then carried in the waters through pores and openings within the sand-gravel deposit. The calcium is 
re-deposited as a calcium carbonate (caliche, $\mathrm{CaCO}_{3}$ ) that coats or cements the sand grains, cobbles, and gravel. Caliche development observed in the sand-gravel deposits of the Wind River Indian Reservation extended to a depth of eight feet below the land surface, but typically extends to a depth of 1-2 ft. The carbonate stage (see Glossary) was observed and recorded in the field as part of this study.

\section{Geologic Investigations and Engineering Tests}

\section{Sand and Gravel}

Natural aggregate consists of sand, gravel, and crushed stone. Sand and gravel is a naturally occurring deposit that is commonly excavated with conventional earth-moving equipment and used as is or is further processed by crushing, screening, and washing. Crushed stone is a manufactured material created by drilling, blasting, and mining hard rock, which is crushed into gravel and sand-sized pieces. This report addresses only sand and gravel.

Sand and gravel is one of the most widely used mineral resources. The production of sand and gravel in Wyoming (table 1), as well as the number of operations providing that material, has generally increased every year until the recent downturn in the housing and construction market. It is expected that this upward trend eventually will resume. Meanwhile, it is becoming more difficult to find new sources of suitable quality aggregate in Wyoming (Harris, 2005). The value of sand and gravel depends in part on the product sold (table 2 ) and its proximity to market.

Table 1. Sand and gravel sold or used by producers, and number of active sand and gravel operations in Wyoming. Data from Bolen (1995-2009); Willett and Bolen (2011).

\begin{tabular}{|c|c|c|c|c|}
\hline Year & $\begin{array}{c}\text { Production of sand } \\
\text { and gravel (thousand } \\
\text { metric tons) }\end{array}$ & $\begin{array}{c}\text { Value } \\
\text { (thousand } \\
\text { dollars) }\end{array}$ & $\begin{array}{c}\text { Unit value } \\
\text { Per ton }\end{array}$ & $\begin{array}{c}\text { Number of active } \\
\text { operations }\end{array}$ \\
\hline 1995 & 3,860 & 17,500 & $\$ 4.55$ & 57 \\
\hline 1996 & 3,420 & 14,700 & $\$ 4.38$ & 49 \\
\hline 1997 & 3,090 & 12,300 & $\$ 3.99$ & 46 \\
\hline 1998 & 4,770 & 18,100 & $\$ 3.80$ & 52 \\
\hline 1999 & 4,410 & 17,200 & $\$ 3.91$ & 70 \\
\hline 2000 & 6,340 & 23,800 & $\$ 3.75$ & 78 \\
\hline 2001 & 7,200 & 35,100 & $\$ 4.87$ & 81 \\
\hline 2002 & 7,710 & 32,100 & $\$ 4.16$ & 86 \\
\hline 2003 & 8,290 & 36,400 & $\$ 4.39$ & 100 \\
\hline 2004 & 8,690 & 38,900 & $\$ 4.48$ & 87 \\
\hline 2005 & 11,700 & 52,400 & $\$ 4.49$ & 87 \\
\hline 2006 & 17,200 & 74,600 & $\$ 4.35$ & 129 \\
\hline 2007 & 19,100 & 95,800 & $\$ 5.02$ & 150 \\
\hline 2008 & 17,500 & 103,000 & $\$ 5.88$ & 134 \\
\hline 2009 & 17,200 & 92,200 & $\$ 5.36$ & 146 \\
\hline 2010 & 15,000 & 69,300 & $\$ 4.26$ & No data \\
\hline
\end{tabular}


Table 2. Construction sand and gravel sold or used in Wyoming in 2002, by major use category. Data from U.S. Geological Survey (2007).

\begin{tabular}{|l|c|c|c|}
\hline \multicolumn{1}{|c|}{ Use (2007) } & $\begin{array}{c}\text { Quantity } \\
\text { (thousand metric tons) }\end{array}$ & $\begin{array}{c}\text { Value } \\
\text { (thousand dollars) }\end{array}$ & $\begin{array}{c}\text { Unit value } \\
\text { Per ton }\end{array}$ \\
\hline Concrete aggregate & 814 & 7,940 & $\$ 9.76$ \\
\hline Bituminous aggregate & 705 & 7,460 & $\$ 10.59$ \\
\hline Road base and coverings & 3,820 & 19,600 & $\$ 5,13$ \\
\hline Other, unspecified, and estimated & 13,719 & 61,166 & $\$ 4.46$ \\
\hline Total or average & 19,058 & 96,166 & $\$ 5.05$ \\
\hline
\end{tabular}

If aggregate is to be produced from new sources certain conditions must be met:

Aggregate must be available — it must exist in sufficient quantity to make mining worthwhile.

Aggregate must be of good quality—it must meet physical and chemical quality requirements for the intended use.

Aggregate must be accessible - it must physically be able to be mined, and must be accessible to transportation systems and to markets.

Aggregate operation must be environmentally acceptable - the site must be permittable and the operation must withstand public scrutiny with minimal impact to the environment or the lifestyle of nearby residents.

\section{Aggregate Availability}

Estimating the volume of a sand and gravel or bedrock deposit is a complex process. Geologists determine the thickness and character of the material overlying the sand and gravel (overburden), the thickness of the sand and gravel, and identify layers of unsuitable material within the deposit (interburden), as well as the yield of usable material from the deposit (fig. 4). The areal extent and thickness of the deposit (used with other factors to determine the quantity of mineable material) commonly results from the origin and subsequent erosional history of the deposit. When only limited data exist, better understood "typical" deposits from other areas can be used to predict overall geometry and the lateral and third dimensional variability of texture of the local deposit (Bliss, 1993).

For this assessment, the quantity estimates of aggregate resources should be considered inferred reserves, which are quantitative estimates based largely on a generalized knowledge of the geologic character of the deposits (Blondel and Lasky, 1956). Our estimates were based on an assumed continuity of materials; the assumption was made by

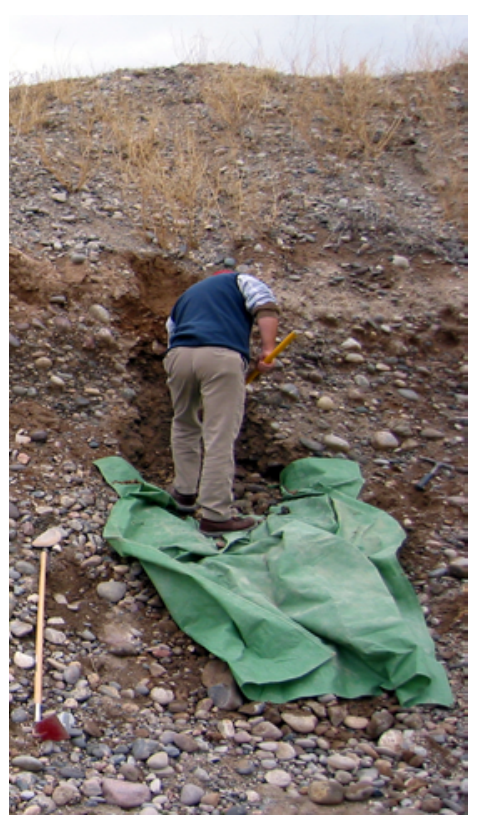

Figure 4. Geologist taking sample from pit face using a technique referred to as vertical trenching. 
comparing the geologic characteristics of the unknown parts of the deposit against other similar, better understood, parts of the deposit, such as observations made in gravel pits or exposed edges of the terraces.

\section{Aggregate Quality}

Aggregate for most construction applications can be produced from sand and gravel deposits containing a wide range of particle sizes, especially if there is a large amount of particles larger than 11/2 inches (in). In addition, the larger the gravel to sand ratio, the better the deposit (Langer and Knepper, 1998). Silt and clay occurring either as layers or interstitial material are undesirable but commonly can be removed by processing. Gravel deposits in the Wind River terraces studied in this project commonly have a large percentage of large particles and commonly do not contain significant amounts of fine materials.

Sand and gravel aggregate should be durable and strong, which means it should support the intended load and resist mechanical breakdown resulting from the action of mixers, mechanical equipment, and traffic. The aggregate should also be sound, which means it should be able to resist weathering such as repeated freezing and thawing or wetting and drying. There is a general relationship between these properties and rock type. Gravel deposits in the Wind River terraces studied in this project commonly contain rock types that yield suitable quality gravel, unless weathered.

Chemical properties of aggregate are important in the manufacture of concrete or bituminous mixes. Ideally, aggregate is inert filler and should not change chemically within the concrete or bituminous mixes. However, some aggregates contain minerals that chemically react with, or otherwise affect, the concrete. This chemical process is referred to as the alkali-silica reaction. Alkali from cement in concrete pore-water solution can react with aggregate that contains certain silica minerals, forming a gel around the aggregate. The gel imbibes water, resulting in the expansion of the aggregate and subsequent destruction of the concrete (Dolar-Mantuani, 1983; Mather and Mather, 1991). Rocks that contain potentially reactive silica in the Wind River terraces include quartzite and volcanic rocks. These rocks are present in most gravel deposits in the Wind River terraces studied in this project.

Sand and gravel should not be excessively weathered. Weathering of gravel clasts lessens the strength of aggregate and increases the overall cost of mining and processing the aggregate. The rate and type of weathering depends on the local climatic conditions, the geometry of the deposit, the relationship to the water table, and the properties of the sand and gravel clasts. Weathering can range from slight discoloration of the clasts, through the introduction of fractures and alteration of minerals, to complete decomposition and disintegration of the clasts. In the Wind River Basin, weathered granite, gneiss and volcanic rocks tend to be unsound, but also commonly are removed from aggregate during processing. 
In arid and semiarid climates, sand and gravel may be coated or cemented with caliche, a calcium carbonate, and may be difficult to extract and process. In the Wind River Basin, caliche thickness ranges from $0-8 \mathrm{ft}$, and commonly is $2-3 \mathrm{ft}$ thick.

The quality of the aggregate may be further defined by its conformance to standard specifications or special specifications set by the user. Because aggregate commonly is used in highway construction, its specifications are usually set by State Departments of Transportation. Most states conform to the grading and testing standards of the American Association of State Highway Transportation Officials (AASHTO) or the American Society for Testing and Materials (ASTM). The specifications for natural aggregate used to make Portland-cement concrete or bituminous mixes are generally more rigorous than for other construction-related uses. Consequently, if sand and gravel can meet the specifications for these uses, it will satisfy almost any other use.

As part of this study, samples were collected in the field (fig. 5) and were taken to Inberg-Miller Engineers,

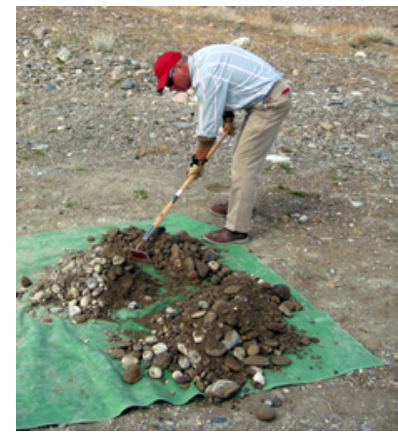

Figure 5. Geologist dividing a large bulk sample using a technique referred to as "cone and quartering." Riverton, Wyo., where they were subjected to three engineering tests (in addition to determining particle size distribution): the Los Angeles Abrasion test, the Sodium Sulfate Soundness test, and tests to determining specific gravity and absorption. The tests generally yielded satisfactory results and are reported in Appendixes 1 and 2.

\section{Aggregate Accessibility}

Aggregate mining requires sufficient land area to locate a processing plant, stockpiles, equipment storage, maintenance areas, and other service areas. The land must also be accessible to standard earth-moving equipment.

Construction aggregates are the lowest price of the mined products, and transportation can be a major part of the cost to the consumer. In Wyoming, the cost of shipping aggregate is about $\$ 1.10$ per ton per mile (Harris, 2005). Therefore sources of aggregate should be located near the point of use. Many of the river terraces along the Wind River where it traverses the Wind River Reservation are underlain with significant quantities of aggregate resources. Because of their proximity to US Route 26, US Route 287 , or other major thoroughfares, some of these resources may be valuable sources for construction aggregate.

\section{Environmental Acceptability}

Sand and gravel resources cannot be obtained without causing some environmental impacts, but most of the environmental impacts are relatively benign and 
are typical of nearly any construction project. The most obvious environmental impacts of sand and gravel mining are the loss of habitat, noise, dust, erosion, sedimentation, and changes to the landscape. Some of the impacts are short-lived, and most are easy to predict and easy to observe. Most impacts can be controlled, mitigated, or kept at tolerable levels and can be restricted to the immediate vicinity of the aggregate operation by employing responsible operational practices that use available technology. Serious environmental health hazards are rare (Langer and others, 2004).

However, some areas have great scenic value or special cultural significance. The project landscape architect prepared a visual assessment of the study area (see below). Similarly, some areas serve as habitat for rare or endangered species. Mining aggregate might be acceptable in some of these areas, but should be conducted only after careful consideration, and then only with extreme prudence. Failure to do so can lead to serious, long-lasting, and irreversible environmental consequences.

\section{Scenic Quality Inventory}

Visual resources of the landscape have long been recognized as having value for enjoyment by people and future generations. Since some landscapes are able to tolerate more change or absorb more impacts (and thus able to withstand mining development) it is important to identify and rate landscape resources before they are developed.

Evaluation of scenic quality is done in relationship to the natural landscape and is a measure of the visual appeal of a parcel of land (Bureau of Land Management, 1986). Scenery is also ranked relative to similar features in the same physiographic region. The project area lies within the Wyoming Basin Physiographic Province (Fenneman, 1946; Liams and others, 1993); thus, scenery in the Wyoming Basin is compared to scenery in the Wyoming Basin, not the Middle or Southern Rocky Mountains.

\section{Landform in the Wind River Reservation}

The mountains and foothills rise steeply from the floor of the Wind River and Wyoming Basins. Elevation differences range from approximately 4,740 ft at Boysen Reservoir to 9,000 ft in the Dubois area. The intermontane basin is relatively flat and the mean elevation of the state of Wyoming is $6,700 \mathrm{ft}$ above sea level. The Wind River Indian Reservation lies within the Wind River/Bighorn River drainage. The average annual precipitation recorded at Boysen Dam, Lander, Riverton, and Shoshoni is 9.3 in and temperatures range from more than $100^{\circ} \mathrm{F}\left(38^{\circ} \mathrm{C}\right)$ to less than $-40^{\circ} \mathrm{F}\left(-20^{\circ} \mathrm{C}\right)$ ( Liams and others, 1993). Precipitation from the Pacific Ocean is blocked by the mountain ranges. Summers are hot and dry, winds are common, and hard, freezing temperatures have occurred in every month of the year (Liams and others, 1993).

The most typical site encountered has gentle slopes and distant views. The landforms give the area an overall appearance of being in wide open country with 
elevation changes apparent in the terraces. Any typical view in the area combines foreground and middle ground with mountains as background images. The lines in the landscape are strongly horizontal in nature and are formed by the shape of the terraces. The texture of the landform is mostly fine/medium with the exception of a few scattered rock outcrops. The second type of landscape has more variety in landform; including a dominant feature such as a butte, irrigated land, or river valley. The most unusual landscape encountered in this assessment has varied topography or running water with a variety of color and vegetation.

\section{Vegetation in the Wind River Reservation}

The Wind River Reservation is dominated by arid grasslands and shrub lands and interrupted by high hills (terraces) and low mountains. The area is substantially natural appearing in character for most people. Parts of the region are used for livestock grazing and agriculture (including grains and hay). Farms are operated near the Wind River and along the irrigation canals. Ranches are located up in the foothills of both the Wind River and Owl Creek ranges (Perkins, 2005).

"Fire, wind, grazing, and variations in precipitation and temperature are the major disturbances in the ecoregion. *** Seasonal browsing and grazing by native herbivores including elk (Cervus elaphus), mule deer (Odocoileus hemionus), and pronghorn (Antilocapra Americana a.) is another influential disturbance. *** Conversion of sagebrush habitat types to grasslands for domestic grazing has taken place in areas where the climate will support grass production” (World Wildlife Fund, 2001, p. 2). Many twotrack roads traverse the area. Soil is exposed and usually is a buff to light-brown color.

Characterizing and tracking vegetation communities would be helpful in more reliably assessing the impact of mineral operations on a landscape or site. It would provide benefits in conservation, identifying rare or endangered species. The existing vegetation, while sparse in many areas, is typical of shrub steppe with sagebrush (Artemesia spp.), often associated with various wheat grasses (Agropyron spp.) or fescue (Festuca spp). Usually grasses are identified by their seed-reproducing structures. The forbs are commonly identified by the pattern and shape of their leaves and the color and structure of their flowers. This characterization is not possible to accomplish in one site visit due to the varying seasons of blooms. For most of the year, the landscape has a strong grey color with a coarse to medium texture in the foreground and medium to fine in the middle and background.

\section{Study Method}

Each site is rated using a table adapted from the BLM Scenic Quality Field Inventory Form 8400-1 for scenic quality assessment of federal lands use (Bureau of Land Management, 1984). Ideally, scenic quality is rated under the most critical conditions (highest user period or season of use, proper atmospheric conditions, etc.) 
(Bureau of Land Management, 1986). The field trip was conducted in April, just after and before two snow storms. The time of year and weather conditions may have limited the extent of views and vegetation (in relation to seasonal changes in forbs and grasses) but do not prevent an analysis of the dominant and important landscape elements. A portion of table 4 illustrates the framework used for the scenic quality data reporting. Although the BLM visual resource management approach is intended for BLM lands, Tribal land may benefit from an application of the BLM methodology. Ranking proposed sites could be used as a guide to analyze potential visual impacts of mineral development based on scenic value in the area. The scenic quality inventory provides a baseline assessment which will allow the Tribes a means to analyze the trade-off between economic, environmental, and scenic considerations.

A scenic quality inventory of each sand and gravel site investigated includes key factors such as: (1) landform/water, (2) vegetation, and (3) cultural modifications (human-made features of the landscape) using vocabulary associated with form, line, color, and texture. One assumption of the BLM Visual Resource Management (VRM) system is that complex landscapes with an abundance and variety in form, line, color, and texture are typically the most interesting and visually appealing. Researchers have found consistent levels of agreement among individuals asked to evaluate visual quality of landscapes using the basic elements of form, line, color, and texture (Bureau of Land Management, 1984). The concept behind this methodology is that the stronger the influence of these elements, the more evidence there will be harmony and contrast (see Glossary), and hence a more diverse and interesting landscape of beauty and ecological quality.

Due to the budget and time constraints of this assessment, one person (a landscape architect) was selected to conduct a visual analysis of the existing landscape, summarized in Appendix 1. The resulting data aid in describing the landscape character: that is, the overall impression created by its unique combination of visual features. Three components are used for this landscape analysis: (1) landscape type, (2) landscape character elements, and (3) landscape analysis factors. Types of landscapes include: panoramic, enclosed, feature, focal, and canopied. Landscape character elements include: form, line, color, and texture. Landscape analysis factors include contrast, sequence, axis, convergence, co-dominance, enframement, and scale (see Glossary). Lands are given an A (high), B (medium), or C (low) rating based on the apparent scenic quality which is determined using seven key factors: landform, vegetation, water, color, adjacent scenery, scarcity, and cultural modifications.

\section{Scenic Quality Rating Results}

A critical first step in understanding and defining the scenic quality of a landscape is cataloging and describing types. A summary of information collected for the Wind River Indian Reservation scenic quality classification is indicated in table 3. The methodology used to arrive at these scenic quality ratings is explained more fully in table 4 (page 23). 
Table 3. Scenic quality rating summary for 13 field sites in the Wind River Indian Reservation. (Based upon methodology developed by the Bureau of Land Management, 1986. Winkleman Dome 1 and Winkleman Dome 2 are listed under Winkleman Dome in Appendix 1).

\begin{tabular}{|c|c|c|c|c|c|c|c|c|c|c|}
\hline $\begin{array}{l}\text { FIELD SITES BY } \\
\text { NAME }\end{array}$ & $\begin{array}{l}\text { ్ㅗㅎ } \\
\text { 흔 } \\
\text { ฮ్ }\end{array}$ & 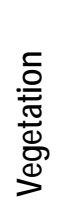 & 离 & 흥 & 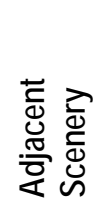 & 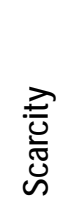 & 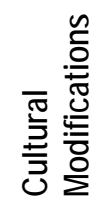 & $\begin{array}{l}\frac{0}{0} \\
\frac{0}{0} \\
\frac{\pi}{0} \\
0\end{array}$ & 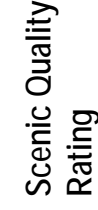 & 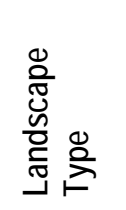 \\
\hline AIRPORT & 2 & 2 & 0 & 1 & 1 & 1 & 0 & 7 & C & Pan* \\
\hline BURMA HILL & 2 & 3 & 0 & 2 & 3 & 3 & 0 & 13 & B & Feature \\
\hline $\begin{array}{l}\text { CROWHEART } \\
\text { BUTTE \# } 1\end{array}$ & 3 & 1 & 0 & 2 & 3 & 3 & 0 & 12 & B & Feature \\
\hline $\begin{array}{l}\text { E BOYSEN } \\
\text { CAUSEWAY }\end{array}$ & 1 & 2 & 0 & 1 & 3 & 1 & -2 & 6 & C & Pan \\
\hline JOHNSTOWN & 1 & 3 & 0 & 2 & 3 & 1 & -2 & 8 & C & Pan \\
\hline KANE DRAW & 2 & 4 & 0 & 3 & 3 & 3 & 0 & 15 & B & Pan \\
\hline KINNEAR & 1 & 2 & 0 & 1 & 1 & 1 & -2 & 4 & C & Pan \\
\hline LE CLAIR & 1 & 2 & 0 & 2 & 5 & 2 & 1 & 13 & B & Pan \\
\hline RED ROCKS & 5 & 5 & 5 & 5 & 0 & 5 & -2 & 23 & A & Enclosed \\
\hline SHEER & 1 & 2 & 0 & 1 & 1 & 1 & -2 & 4 & C & Pan \\
\hline WILLOW CREEK & 3 & 5 & 0 & 3 & 4 & 4 & 2 & 21 & A & Focal \\
\hline $\begin{array}{l}\text { WINKLEMAN } \\
\text { DOME } 1\end{array}$ & 1 & 1 & 0 & 1 & 4 & 2 & -2 & 7 & C & Pan \\
\hline $\begin{array}{l}\text { WINKLEMAN } \\
\text { DOME } 2\end{array}$ & 3 & 2 & 0 & 3 & 4 & 3 & -2 & 11 & C & Pan \\
\hline
\end{tabular}

*Pan=panoramic

According to the BLM (1984 and 1986), a scenic quality inventory is one part of determining visual resource inventory classes (objectives). Future work to be considered includes:

- A sensitivity analysis (ranked high, medium, or low) - the measure of public concern for scenic quality that changes over time. The Tribes may want to consider types of users, amount of use, public interest, adjacent land use, and special areas (including areas of religious, archeological, environmental, or cultural significance).

- A map delineating distance zones (foreground, background, and seldom seen) showing relative visibility from travel routes and/or observation points.

\section{Framework for Data Reporting (Table 4)}

Table 4 is the framework followed for data reporting in this assessment. The table includes the information necessary to understand the data from geologic field notes on sand and gravel deposits, engineering tests, and scenic quality for the all of the sites investigated on the Wind River Indian Reservation, Wyo. In writing about geology and landscape, several terms may not be fully understood by all readers. Before passing on to the substance of this report, then, definitions are provided as they are introduced in the table. Appendix 1 contains the raw data for each site and follows the framework of 
table 4. A glossary section summarizing technical terms has been included for the benefit of non-specialists.

The first component of the framework is a cover sheet with the site name, location, USGS topographic sheet, date of sample collection, and location map. The upper right hand corner identifies the site name and sheet number for the data report. Pagination at the bottom of the page continues sequentially in order to locate sites easily from the table of contents.

The second component is boxes identifying the sample number, geologic observations, engineering tests, production constant, and conclusions. A geologic column and photograph are included that illustrate the stratigraphy at the evaluation sites.

The third component is the scenic quality field inventory, landscape narrative, scenic quality, score, and scenic quality classification. Photographs are included that aid in the explanation or rationale for rating the visual quality of the scenic resources. 
Table 4. Framework in Appendix 1 for data reporting sand and gravel studies on the Wind River Indian Reservation.

SITE NAME: Sheet 1 of 6

Site Name: Name assigned by BIA

Location: Section, township and range

USGS Topographic Sheet: Name from topographic sheet

Date: Date of field work

Aerial photograph overlain with contour lines,

roads, water bodies, and sample site location

(yellow-colored dot).

SCALE BAR 


\section{Site Name: Name assigned by BIA}

Location: Half or quarter section, quarter section, section, township, range, Wind River Meridian USGS Topographic Sheet: Name from topographic sheet

\begin{tabular}{|c|c|}
\hline \multicolumn{2}{|l|}{ GEOLOGIC DESCRIPTION } \\
\hline Sample number & Numbers assigned at each site, starting with \#1. \\
\hline Location & Latitude and longitude in degrees, minutes, and seconds \\
\hline Terrace level Qt & $\begin{array}{l}\text { As assigned by Morris and others (1959), or converted from WR units assigned by Chadwick and others } \\
\text { (1997) }\end{array}$ \\
\hline Gravel thickness (feet) & Measured at pit face (see Glossary). \\
\hline Overburden thickness (feet) & $\begin{array}{l}\text { Overburden is soil or other material other than gravel that overlies the gravel. Measured at pit face (See } \\
\text { Glossary).) }\end{array}$ \\
\hline Water table & Location of water table, if observed \\
\hline Caliche thickness (feet) & $\begin{array}{l}\text { Caliche (see glossary) is calcium carbonate }\left(\mathrm{CaCO}_{3}\right) \text { commonly occurring in the subsurface as a white } \\
\text { crust on stones. Measured at pit face. }\end{array}$ \\
\hline Maximum carbonate stage & $\begin{array}{l}\text { Maximum carbonate stage refers to the degree of coating or cementation of particles by } \mathrm{CaCO}_{3} \text { (caliche) } \\
\text { in gravel (Birkeland, 1999). Stage I, thin discontinuous coatings on particles; stage II, continuous } \\
\text { coatings; stage III, coalesced coatings; stage IV, pore space plugged by } \mathrm{CaCO}_{3} \text {. Stages II and III are } \\
\text { common in Wind River gravel. Carbonate stage varies within an outcrop, from none to the maximum } \\
\text { specified. Caliche coatings may or may not be detrimental to the quality of the aggregate. }\end{array}$ \\
\hline Maximum clast weathering & $\begin{array}{l}\text { Maximum clast weathering refers the degree of alteration and disintegration of clasts in gravel. Not all } \\
\text { clasts show maximum weathering; only granite-gneiss and volcanic rocks were evaluated. (See } \\
\text { Glossary for an explanation of how stage of weathering is determined.) Stage 1, minor pitting or } \\
\text { oxidation; stage 2, moderate pitting, slight fracturing, and oxidation; stage 3, highly pitted, iron stains, } \\
\text { strong fracturing; and stage 4, strongly weathered and fractured, disintegrates easily. } \\
\text { Rocks weathered to stage } 3 \text { may be unsuitable for aggregate and rocks weathered to stage } 4 \text { are } \\
\text { unsuitable for aggregate. Unsuitable rocks commonly are broken down and removed during processing. }\end{array}$ \\
\hline $\begin{array}{l}\text { Lithologies (expressed as a } \\
\text { percent of the total sample) }\end{array}$ & $\begin{array}{l}\text { Lithology refers to the type of rock. Approximately } 100 \text { rock particles were randomly selected from each } \\
\text { gravel sample and were identified in the field. }\end{array}$ \\
\hline Granite-gneiss & $\begin{array}{l}\text { Granite-gneiss rocks are light-colored, coarsely crystalline rocks. They commonly make good aggregate } \\
\text { although some minerals in the rocks may weather, weakening the rocks and increasing the amount of } \\
\text { fine material in the deposit. }\end{array}$ \\
\hline Mafic plutonic-metamorphic & $\begin{array}{l}\text { Mafic-plutonic-metamorphic rocks are dark-colored, coarsely crystalline rocks. They commonly make } \\
\text { good aggregate although some large crystals in the rocks may weaken the aggregate. }\end{array}$ \\
\hline Quartzite & $\begin{array}{l}\text { Quartzite is a dark or light colored quartz dominant rock that is hard, dense, and durable. It commonly is } \\
\text { an excellent rock for aggregate although it may be difficult to crush. }\end{array}$ \\
\hline Vein quartz & $\begin{array}{l}\text { Vein quartz is hard and strong, but may be brittle. Vein quartz may also be reactive when used in } \\
\text { Portland cement concrete. }\end{array}$ \\
\hline Sandstone & $\begin{array}{l}\text { Sandstone has a wide variety of properties and may make good aggregate when well cemented and } \\
\text { strong, or make poor aggregate when poorly cemented and weak. }\end{array}$ \\
\hline Limestone & $\begin{array}{l}\text { Limestone (includes other carbonate rocks including marble and dolomite) has a wide variety of } \\
\text { properties and may make good or poor aggregate. }\end{array}$ \\
\hline Chert & $\begin{array}{l}\text { Chert is hard and strong, but may be brittle. Chert commonly is reactive when used in Portland cement } \\
\text { concrete. }\end{array}$ \\
\hline Volcanics & $\begin{array}{l}\text { Volcanic rocks are light- or dark-colored, finely crystalline rocks. They commonly make good aggregate, } \\
\text { but may be reactive when used in Portland cement concrete. }\end{array}$ \\
\hline Total & $\begin{array}{l}\text { The total of all lithologies of rocks commonly equals } 100 \text { percent, but may be more or less than } 100 \\
\text { percent due to rounding. }\end{array}$ \\
\hline
\end{tabular}


SITE NAME: Sheet 3 of 6

SITE NAME: Sheet 4 of 6

\begin{tabular}{|c|c|}
\hline \multicolumn{2}{|l|}{ ENGINEERING TESTS } \\
\hline Sample number & $\begin{array}{l}\text { Numbers assigned at each site, starting with \#1. Samples from other agencies are } \\
\text { identified. }\end{array}$ \\
\hline \multicolumn{2}{|c|}{ Particle Size Analysis- See Glossary for an expanded description of particle size analysis } \\
\hline $\begin{array}{l}\text { Maximum clast size } \\
\text { (inches) }\end{array}$ & $\begin{array}{l}\text { Longest dimension of largest clast observed at the site. Large clasts, especially } \\
\text { boulders, may complicate excavation and processing of gravel. Boulders commonly } \\
\text { are not processed, and are set aside for use as rip rap or decorative landscaping rock. }\end{array}$ \\
\hline Size distribution (percent) & $\begin{array}{l}\text { The grain size distribution of particles was calculated as the percentage of the sample } \\
\text { for each grain size class. }\end{array}$ \\
\hline Cobbles & Cobbles are retained on the 3 -in sieve \\
\hline Coarse Gravel & Coarse gravel passes through the 3 -in sieve and is retained on the 3/4"sieve. \\
\hline Fine Gravel & $\begin{array}{l}\text { Fine gravel passes through the } 3 / 4 \text {-in sieve and is retained on the } \# 4 \text { (4.75 millimeter } \\
(\mathrm{mm}) \text { ) sieve. }\end{array}$ \\
\hline Sand & $\begin{array}{l}\text { Fine gravel passes through the } \# 4 \text { ( } 4.75 \mathrm{~mm} \text { or } 0.187 \mathrm{in}) \text { sieve and is retained on the } \\
\# 200(75 \text { micrometer }(\mu \mathrm{m})) \text { sieve. }\end{array}$ \\
\hline Fines & Fines pass through the $\# 200$ ( $75 \mu \mathrm{m}$ or $0.003 \mathrm{in})$ sieve. \\
\hline Total & $\begin{array}{l}\text { The total of all grain size classes commonly equals } 100 \text { percent, but may be more or } \\
\text { less than } 100 \text { percent due to rounding }\end{array}$ \\
\hline LA Value & $\begin{array}{l}\text { The Los Angeles (LA) Abrasion test is a measure of the ability of aggregate to resist } \\
\text { breakdown due to abrasion, impact, and grinding. It is a benchmark test commonly } \\
\text { applied to potential aggregate resources. LA values should be less than } 30 \text { percent. } \\
\text { See Glossary for an expanded description of the Los Angeles Abrasion test }\end{array}$ \\
\hline Soundness & $\begin{array}{l}\text { The soundness test is a measure of the ability of aggregate to resist breakdown due to } \\
\text { cycles of wetting and drying or freezing and thawing. The test commonly is applied to } \\
\text { different size ranges. Loss should be less than } 10 \text { percent when sodium sulfate is } \\
\text { used, which was used for these tests (ASTM C-33). See Glossary for an expanded } \\
\text { description of the soundness test. }\end{array}$ \\
\hline Specific gravity & $\begin{array}{l}\text { Specific gravity is the ratio of the mass of a given volume of aggregate to the mass of } \\
\text { an equal volume of water. Very low specific gravity frequently indicates aggregate that } \\
\text { is porous, weak, or absorptive. High specific gravity generally indicates high-quality } \\
\text { aggregate. Specific gravity should be } 2.55 \text { or greater. See Glossary for an expanded } \\
\text { description of testing to determine specific gravity. }\end{array}$ \\
\hline Percent absorption & $\begin{array}{l}\text { Absorption should not exceed } 3 \text { percent. In addition, rocks with water absorption of } 2 \\
\text { percent or less will usually produce good aggregate, whereas otherwise suitable rocks } \\
\text { with a water absorption that exceeds } 4 \text { percent may not (Smith and Collis, 2001). See } \\
\text { Glossary for an expanded description of testing to determine absorption. }\end{array}$ \\
\hline
\end{tabular}




\begin{tabular}{|l|l|}
\hline PRODUCTION CONSTANT \\
\hline Estimated thickness & Estimated thickness of deposit in vicinity of sample site \\
\hline $\begin{array}{l}\text { Constant - } \\
\text { Maximum } \\
\text { recoverable } \\
\text { product. }\end{array}$ & $\begin{array}{l}\text { Throughout the United States about 5 percent of the total production of an aggregate } \\
\text { operation consists of unmarketable waste (not including overburden) (Hudson and others, } \\
\text { 1997). This is the minimum waste factor applied to aggregate in this study. This value can } \\
\text { be adjusted based on experience gained during the processing of material. }\end{array}$ \\
\hline & $\begin{array}{l}\text { Gravel clasts larger than 3-in may be difficult to handle and crush. This material may be set } \\
\text { aside and sold as rip rap, decorative stone, or other products. Furthermore, throughout the } \\
\text { United States, about 23.8 percent of the total production of an aggregate operation consists } \\
\text { of minus 3/8-in product (not including overburden) that is very difficult to market (Hudson } \\
\text { and others, 1997). This constant calculates production from particles less than 3-in and } \\
\text { recoverable product } \\
\text { includes a waste factor of 23.8 percent, assuming none of the minus 3/8-in material will be } \\
\text { marketed. These values can be adjusted based on experience gained during the processing } \\
\text { and marketing of material. }\end{array}$ \\
\hline $\begin{array}{l}\text { CoNCLUSIONS } \\
\text { Describes aggregate suitability for use in Portland cement concrete, asphalt, and as road base. Lists deleterious } \\
\text { materials. }\end{array}$ \\
\hline
\end{tabular}

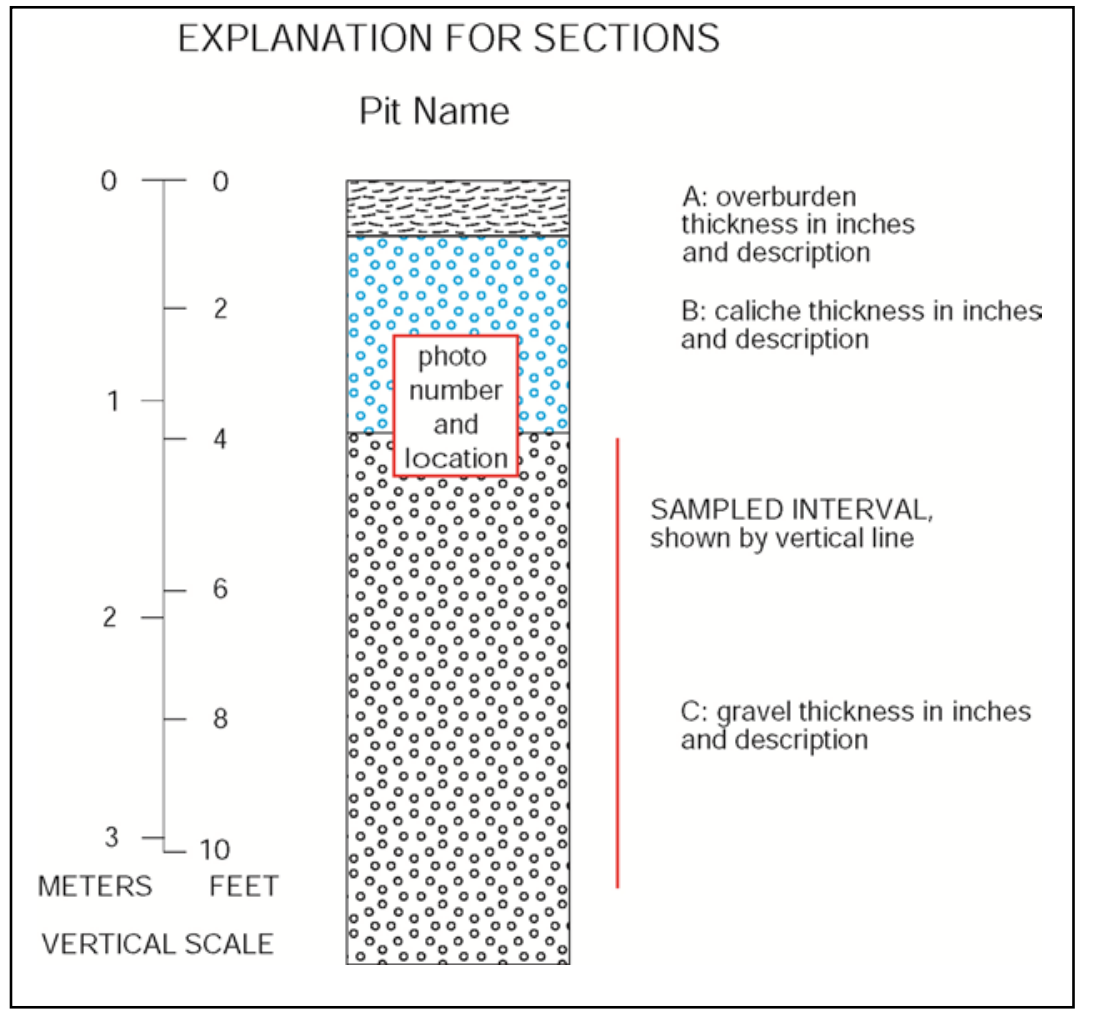




\begin{tabular}{|c|c|c|c|}
\hline \multicolumn{4}{|c|}{ SCENIC QUALITY FIELD INVENTORY AND EVALUATION CHART* } \\
\hline \multicolumn{4}{|l|}{ LANDSCAPE TYPE } \\
\hline \multicolumn{4}{|c|}{ Panoramic, feature, enclosed, or focal (see Glossary for definitions). } \\
\hline \multicolumn{4}{|c|}{ LANDSCAPE ANALYSIS FACTORS } \\
\hline \multicolumn{4}{|c|}{$\begin{array}{l}\text { Contrast, sequence, axis, convergence, co-dominance, enframement, and scale if applicable (see Glossary for } \\
\text { definitions). }\end{array}$} \\
\hline \multicolumn{4}{|c|}{ LANDSCAPE CHARACTER } \\
\hline \multicolumn{4}{|c|}{$\begin{array}{l}\text { The arrangement of a particular landscape as formed by the variety and intensity of the landscape features and the } \\
\text { four basic elements of form, line, color, and texture. }\end{array}$} \\
\hline Visual Features & LANDFORM/WATER & VEGETATION & STRUCTURE \\
\hline $\begin{array}{l}\text { FORM } \\
\text { The mass or shape of an } \\
\text { object or of a combination } \\
\text { of objects which appear } \\
\text { unified. }\end{array}$ & $\begin{array}{l}\text { The dominant physical } \\
\text { topographical element } \\
\text { (earth and water) upon } \\
\text { which all other elements in } \\
\text { the landscape rest. }\end{array}$ & $\begin{array}{l}\text { Plant size and form is the } \\
\text { most notable visual } \\
\text { characteristic of plant } \\
\text { material (Booth, 1983). }\end{array}$ & $\begin{array}{l}\text { Man-made features are } \\
\text { typically geometric and } \\
\text { simple. Spaces may be } \\
\text { delineated by buildings, } \\
\text { storage tanks, electrical } \\
\text { transmission facilities, and } \\
\text { so on. }\end{array}$ \\
\hline $\begin{array}{l}\text { LINE } \\
\text { The path (real or imagined) } \\
\text { that the eye follows in a } \\
\text { landscape. }\end{array}$ & $\begin{array}{l}\text { Edge, band, and silhouette } \\
\text { are line types. Examples } \\
\text { for landform include ridges } \\
\text { and skylines. }\end{array}$ & $\begin{array}{l}\text { Same as landform types } \\
\text { only refers to changes in } \\
\text { vegetation or individual } \\
\text { trees. An example is the } \\
\text { boundary between areas } \\
\text { dominated by trees and } \\
\text { those in which there are } \\
\text { no trees. }\end{array}$ & $\begin{array}{l}\text { Same as landform types. } \\
\text { Traditionally, the effect of } \\
\text { man-made elements tends } \\
\text { to be straight and hard. } \\
\text { Examples include roads, } \\
\text { poles, and fences. }\end{array}$ \\
\hline $\begin{array}{l}\text { COLOR } \\
\text { The property of reflecting } \\
\text { light of a particular intensity } \\
\text { and wavelength; light colors } \\
\text { typically recede and dark } \\
\text { colors typically advance. }\end{array}$ & $\begin{array}{l}\text { Color clearly distinguishes } \\
\text { a form from its } \\
\text { environment and is the } \\
\text { major visual property of } \\
\text { surfaces. }\end{array}$ & $\begin{array}{l}\text { Plant color is significant } \\
\text { because it is easily seen } \\
\text { and can be noticed at } \\
\text { relatively great distances } \\
\text { in the landscape (Booth, } \\
\text { 1983). }\end{array}$ & $\begin{array}{l}\text { Same as landform. All } \\
\text { surfaces have some } \\
\text { inherent color. }\end{array}$ \\
\hline $\begin{array}{l}\text { TEXTURE } \\
\text { The aggregation of small } \\
\text { forms or color mixtures into } \\
\text { a continuous surface } \\
\text { pattern; determined by light } \\
\text { and shadow. }\end{array}$ & $\begin{array}{l}\text { The surface characteristic } \\
\text { that makes patterns } \\
\text { relatively coarse or fine, } \\
\text { rough or smooth. Texture } \\
\text { varies with distance and } \\
\text { seasons. }\end{array}$ & Same as landform. & Same as landform. \\
\hline \multicolumn{4}{|l|}{ LANDSCAPE NARRATIVE } \\
\hline
\end{tabular}

"Based on the Visual Resource Management Manual 8400 BLM Standards, Scenic Quality Inventory and Evaluation Chart. (Bureau of Land Management, 1984; Bureau of Land Management, 1986) 
SITE NAME: Sheet 6 of 6

\begin{tabular}{|c|c|c|c|}
\hline $\begin{array}{l}\text { CENIC QUALITY FIELD IN } \\
\text { CENIC QUALITY RATING } \\
\text { erived by evaluating the se }\end{array}$ & $\begin{array}{l}\text { NTORY AND EVALUATI } \\
\text { key factors and rating cri }\end{array}$ & $\begin{array}{l}\text { HART cont. } \\
\text { jelow. }\end{array}$ & \\
\hline Key Factors & $\begin{array}{l}\text { Rating Criteria and Score. V } \\
\text { scores only. It is also possib }\end{array}$ & $\begin{array}{l}\text { ues for each rating criteri } \\
\text { to assign scores within th }\end{array}$ & $\begin{array}{l}\text { maximum and minimum } \\
\text { ranges. }\end{array}$ \\
\hline $\begin{array}{l}\text { LANDFORM } \\
\text { Topography becomes more } \\
\text { interesting as it gets } \\
\text { steeper or more massive, or } \\
\text { more sculptured. They may } \\
\text { be monumental or } \\
\text { exceedingly artistic and } \\
\text { subtle. }\end{array}$ & $\begin{array}{l}\text { High vertical relief as } \\
\text { expressed in prominent } \\
\text { cliffs, spires, or massive } \\
\text { rock outcrops; or severe } \\
\text { surface variations or highly } \\
\text { eroded formations; or } \\
\text { detail features dominant } \\
\text { and exceptionally striking. } \\
\mathbf{5}\end{array}$ & $\begin{array}{l}\text { Steep canyons, mesas, } \\
\text { buttes, cinder cones; or } \\
\text { interesting erosional } \\
\text { patterns or variety in size } \\
\text { and shape of landforms; } \\
\text { or detail features which } \\
\text { are interesting though not } \\
\text { dominant or exceptional. } \\
\mathbf{3}\end{array}$ & $\begin{array}{l}\text { Low rolling hills, foothills, or } \\
\text { flat valley bottoms; or few } \\
\text { or no interesting landscape } \\
\text { features. }\end{array}$ \\
\hline $\begin{array}{l}\text { VEGETATION } \\
\text { Gives consideration to the } \\
\text { variety of patterns, forms, } \\
\text { and textures created by } \\
\text { plant life. }\end{array}$ & $\begin{array}{l}\text { A variety of vegetative } \\
\text { types as expressed in } \\
\text { interesting forms, textures, } \\
\text { and patterns. } \\
\mathbf{5}\end{array}$ & $\begin{array}{l}\text { Some variety of } \\
\text { vegetation, but only one } \\
\text { or two major types. } \\
3\end{array}$ & $\begin{array}{l}\text { Little or no variety or } \\
\text { contrast in vegetation. }\end{array}$ \\
\hline $\begin{array}{l}\text { WATER } \\
\text { The ingredient which adds } \\
\text { movement or serenity to a } \\
\text { scene. }\end{array}$ & $\begin{array}{l}\text { Clear and clean appearing, } \\
\text { still, or cascading white } \\
\text { water, any of which are a } \\
\text { dominant factor in the } \\
\text { landscape. } \\
\mathbf{5}\end{array}$ & $\begin{array}{l}\text { Flowing, or still, but not } \\
\text { dominant in the } \\
\text { landscape. }\end{array}$ & $\begin{array}{l}\text { Absent, or present, but not } \\
\text { noticeable. }\end{array}$ \\
\hline $\begin{array}{l}\text { COLOR } \\
\text { Consider the overall } \\
\text { color(s) of the basic } \\
\text { components of the } \\
\text { landscape as they appear } \\
\text { during seasons or periods } \\
\text { of high use. Key factors } \\
\text { are variety, contrast, and } \\
\text { harmony. }\end{array}$ & $\begin{array}{l}\text { Rich color combinations, } \\
\text { variety, or vivid color; or } \\
\text { pleasing contrasts in the } \\
\text { soil, rock, vegetation, } \\
\text { water, or snow fields. }\end{array}$ & $\begin{array}{l}\text { Some intensity or variety } \\
\text { in colors and contrast of } \\
\text { the soil, rock, and } \\
\text { vegetation, but not a } \\
\text { dominant scenic element. }\end{array}$ & $\begin{array}{l}\text { Subtle color variations, } \\
\text { contrast, or interest; } \\
\text { generally mute tones. }\end{array}$ \\
\hline $\begin{array}{l}\text { ADJACENT SCENERY } \\
\text { Degree to which scenery } \\
\text { outside the scenery unit } \\
\text { being rated enhances the } \\
\text { overall impression of the } \\
\text { scenery within the area. }\end{array}$ & $\begin{array}{l}\text { Adjacent scenery greatly } \\
\text { enhances visual quality. }\end{array}$ & $\begin{array}{l}\text { Adjacent scenery } \\
\text { moderately enhances } \\
\text { overall visual quality. }\end{array}$ & $\begin{array}{l}\text { Adjacent scenery has little } \\
\text { or no influence on overall } \\
\text { visual quality. }\end{array}$ \\
\hline $\begin{array}{l}\text { SCARCITY } \\
\text { Added importance to scenic } \\
\text { features that appear to be } \\
\text { relatively unique or rare } \\
\text { within the physiographic } \\
\text { region. }\end{array}$ & $\begin{array}{l}\text { One of a kind; or unusually } \\
\text { memorable, or very rare } \\
\text { within region. }\end{array}$ & $\begin{array}{l}\text { Distinctive, though } \\
\text { somewhat similar to } \\
\text { others within the region. }\end{array}$ & $\begin{array}{l}\text { Interesting within its setting, } \\
\text { but fairly common within } \\
\text { the region. }\end{array}$ \\
\hline $\begin{array}{l}\text { CULTURAL } \\
\text { MODIFICATIONS } \\
\text { The change in landscape } \\
\text { by humans which may add } \\
\text { or detract from the scenery. }\end{array}$ & $\begin{array}{l}\text { Modifications add favorably } \\
\text { to visual variety while } \\
\text { promoting visual harmony. } \\
2\end{array}$ & $\begin{array}{l}\text { Modifications add little or } \\
\text { no visual variety to the } \\
\text { area, and introduce no } \\
\text { discordant elements. } \\
0\end{array}$ & $\begin{array}{l}\text { Modifications add variety } \\
\text { but are very discordant and } \\
\text { promote strong } \\
\text { disharmony. } \\
-4\end{array}$ \\
\hline TOTAL SCORE & The sum of the individual s & s determines the overa & enic quality classification. \\
\hline $\begin{array}{l}\text { SCENIC QUALITY } \\
\text { CLASSIFICATION }\end{array}$ & $\begin{array}{l}\text { A being the highest rating, } \\
A=19 \text { or more } B=12-1\end{array}$ & $\begin{array}{l}\text { moderate rating, and } \mathrm{C} \\
\mathrm{C}=11 \text { or less }\end{array}$ & 1 \\
\hline
\end{tabular}




\section{References Cited}

American Society of Testing and Materials, 2003, Annual book of ASTM standards, Volume 04.02 —Concrete and aggregates: West Conshohocken, Penn., ASTM International, $841 \mathrm{p}$.

Birkeland, P.W., 1999, Soils and geomorphology (3rd ed): New York, Oxford University Press, 448 p.

Bliss, J.D., 1993, Modeling sand and gravel deposits-Initial strategy and preliminary examples: U.S. Geological Survey Open-File Report 93-200, 31 p.

Blondel, F., and Lasky, S.G., 1956, Mineral reserves and mineral resources: Economic Geology, v. 51, p. 686-697.

Bolen, W.P., 1995-2009, Construction sand and gravel: U.S. Geological Survey Minerals Yearbooks.

Booth, N.K., 1983, Basic elements of landscape architectural design: New York, Elsevier, 315 p.

Bureau of Land Management, 1984, Bureau of Land Management Handbook 8400 Visual Resource Management: Washington D.C., Bureau of Land Management, 15 p.

Bureau of Land Management, 1986, Visual resource inventory: Washington D.C., U.S. Government Printing Office, BLM Manual Handbook 8410-1, 23 p., accessed July 29, 2005, at http://www.blm.gov/nstc/VRM/8410.html

Chadwick, O.A., Hall, R.D., and Phillips, F.M., 1997, Chronology of Pleistocene glacial advances in the central Rocky Mountains: Geological Society of America Bulletin, v. 109 , no. 11 , p. $1,443-1,452$.

Dahms, D.E., Hall, R.D., Shroba, R.R., Sorenson, C.J., Lynch, E.A., and Applegarth, M.T., 2003, The Rocky Mountain glacial model—-The Wind River Range, Wyoming, in Easterbrook, D.J., ed., Quaternary geology of the United States, INQUA 2003 Field Guide Volume, XVI INQUA Congress: Reno, Nev., Desert Research Institute, p. 345-364.

Dolar-Mantuani, Ludmila, 1983, Handbook of concrete aggregates, a petrographic and technological evaluation: Park Ridge, N.J., Noyes Publications, 345 p.

Fenneman, N.M., 1946, Physiographic map-Continental United States: Washington D.C., Bureau of Land Management, accessed July 29, 2005, at http://www.blm.gov/nstc/VRM8410b.html 
Gersic, Joseph, 1993, Nonmetallic mineral resources of the Wind River Indian Reservation (excluding fuels), in Keefer, W.R., Metzger, W.J., and Godwin, L.H., eds., Wyoming Geological Association Special Symposium on Oil and Gas and Other Resources of the Wind River Basin, Wyoming, Casper, Wyoming, August 14-17, 1993, Proceedings: Casper, Wyo., Wyoming Geological Association, p. 419-425.

Harris, R.E, 2005, Construction aggregate in Wyoming: Laramie, Wyo., Wyoming State Geological Survey, accessed on August 15, 2005, at http://www.wsgs.uwyo.edu/minerals/aggregate.aspx

Hudson, W.R., Little, D., Razmi, A.M., Anderson, V., and Weissmann, A., 1997, An investigation of the status of by-product fines in the United States: International Center for Aggregates Research Report ICAR-101-1, 184 p.

Johnson, R.C., Clark, A.C., Barker, C.E., Crysdale, B.L., Higley, D.K., Szmajter, Richard, and Finn, T.M., 1993, Coalbed methane potential of the Upper Cretaceous Mesaverde and Meeteetse Formations, Wind River Reservation, Wyoming, in Keefer, W.R., Metzger, W.J., and Godwin, L.H., eds., Wyoming Geological Association Special Symposium on Oil and Gas and Other Resources of the Wind River Basin, Wyoming, Casper, Wyoming, August 14-17, 1993, Proceedings: Casper, Wyo., Wyoming Geological Association, p. 215-242.

Johnson, R.C., and Flores, R.M., 1993, Stratigraphy, areal distribution, and paleodepositional environments of Fort Union Formation coal beds, Wind River Reservation, Wyoming-Implications for coalbed methane development, in Keefer, W.R., Metzger, W.J., and Godwin, L.H., eds., Wyoming Geological Association Special Symposium on Oil and Gas and Other Resources of the Wind River Basin, Wyoming, Casper, Wyoming, August 14-17, 1993: Casper, Wyo., Wyoming Geological Association, p. 281-294.

Keefer, W.R., 1965a, Stratigraphy and geologic history of the uppermost Cretaceous, Paleocene, and lower Eocene rocks in the Wind River Basin, Wyoming: U.S. Geological Survey Professional Paper 495-A, 77 p.

Keefer, W.R., 1965b, Geologic history of Wind River Basin, central Wyoming: American Association of Petroleum Geologists Bulletin, v. 49, no. 11, p. 1,878-1,892.

Keefer, W.R., Metzger, W.J., and Godwin, L.H., eds., 1993, Wyoming Geological Association Special Symposium on Oil and Gas and Other Resources of the Wind River Basin, Wyoming, Casper, Wyoming, August 14-17, 1993: Casper, Wyo., Wyoming Geological Association, 426 p., plus plates.

Keefer, W.R., and Van Lieu, J.A., 1966, Paleozoic formations in the Wind River Basin, Wyoming: U.S. Geological Survey Professional Paper 495-B, 60 p. 
Langer, W.H., and Knepper, D.K., 1998, Geologic characterization of natural aggregate, in, Bobrowsky, P.T., ed., Aggregate resources-A global perspective: Rotterdam, Netherlands, A.A. Balkema, p. 275-293.

Langer, W.H., Drew, L.J., and Sachs, J.S., 2004, Aggregate and the environment: American Geological Institute Environmental Awareness Series 8, 64 p.

Liams, J.E., Dillahunty, C.E., Jr., Jelden, S.J., Moore, J.P., Paris, Christopher, Ravenholt, H.B., and Suhr, M.C., 1993, Soil survey of Fremont County, East Part and Dubois Area, Wyoming: National Cooperative Soil Survey, 449 p., map(s).

Machette, M.N., 1985, Calcic soils of the southwestern United States, in Weide, D.L., ed., Soils and quaternary geology of the southwestern United States: Geological Society of America Special Paper 203, p. 1-21.

Mather, Katherine, and Mather, Bryant, 1950, Method of petrographic examination of aggregates for concrete: Proceedings, American Society for Testing and Materials, v. 50, p. 1288-1312.

McGreevy, L.J., Hodson, W.G., and Rucker, S.J., IV, 1969, Ground-water resources of the Wind River Indian Reservation, Wyoming: U.S. Geological Survey Water-Supply Paper 1576-I, 145 p., 3 plates.

Morris, D.A., Hackett, O.M., Vanlier, K.E., and Moulder, E.A., 1959, Ground-water resources of Riverton Irrigation Project Area, Wyoming: U.S. Geological Survey Water-Supply Paper 1375, 205 p., 6 plates.

Murphy, J.F., and Richmond, G.M., 1965, Geologic map of Bull Lake West, Wyoming: U.S. Geological Survey Geologic Quadrangle Map GQ-432, scale 1:24,000.

Perkins, Daniel, 2005, Communicating with the Wind River Reservation concerning environmental and conservation issues: SWCS (Soil and Water Conservation Society) International Conference, Rochester, New York, July 30- August 4, 2005, Proceedings: Ankeny, Iowa, Soil and Water Conservation Society, accessed August 1, 2005, at http://www.swcs.org/en/swcs_international_conference/2005_annual_conference/ general_information/poster_presentations/

Peterson, E.K., 1993, Wind River Indian Reservation coal resources, in Keefer, W.R., Metzger, W.J., and Godwin, L.H., eds., Wyoming Geological Association Special Symposium on Oil and Gas and Other Resources of the Wind River Basin, Wyoming, Casper, Wyoming, August 14-17, 1993: Casper, Wyo., Wyoming Geological Association, p. 207-242.

Richmond, G.M., 1964, Three pre-Bull Lake tills in the Wind River Mountains, Wyoming, reinterpreted: U.S. Geological Survey Professional Paper 501-D, p. 104-109. 
Richmond, G.M., 1965, Glaciation of the Rocky Mountains, in Wright, H.E., Jr., Frey, D.G., eds., The Quaternary of the United States: Princeton, N.J., Princeton University Press, p. 217-230.

Richmond, G.M., and Murphy, J.F., 1965, Geologic map of Bull Lake East, Wyoming: U.S. Geological Survey Geologic Quadrangle Map GQ-431, scale 1:24,000.

Richmond, G.M., and Murphy, J.F., 1989, Preliminary Quaternary geologic map of the Dinwoody Lake area, Fremont County, Wyoming: U.S. Geological Survey Open-File Report 89-435, 2 p.

Shroba, R.R., 1989, Physical properties and laboratory data for soils formed in Pleistocene tills at Bull Lake, Dinwoody Lakes, and Fremont Lake, Fremont and Sublette Counties, Wyoming: U.S. Geological Survey Open-File Report 89-370, 14 p.

Smith, M.R., and Collis, L., eds., 2001, Aggregates—Sand, gravel and crushed rock aggregates for construction purposes: London, U.K., The Geological Society, Geological Society Engineering Geology Special Publication No. 17, 339 p.

U.S. Forest Service, 1995, Landscape aesthetics-A handbook for scenery management: Agriculture Handbook No. 701, various pagination.

U.S. Geological Survey, 2007, 2007 Minerals yearbook, Wyoming: U.S. Geological Survey Minerals Yearbook, p. 53.1-53.8.

Willett, J.C., and Bolen, W.P., 2011, Crushed stone and sand and gravel in the first quarter 2011: U.S. Geological Survey Mineral Industry Surveys, 7 p.

Willis, J.J., and Groshong, R.H., Jr., 1993, Deformational style of the Wind River uplift and associated flank structures, Wyoming, in Keefer, W.R., Metzger, W.J., and Godwin, L.H., eds., Wyoming Geological Association Special Symposium on Oil and Gas and Other Resources of the Wind River Basin, Wyoming, Casper, Wyoming, August 14-17, 1993: Casper, Wyo., Wyoming Geological Association, p. 337-375.

World Wildlife Fund, 2001, Wyoming basin shrub steppe (NA1313): Washington, D.C., World Wildlife Fund, accessed August 4, 2005, at http://www.worldwildlife.org/wildworld/profiles/terrestrial/na/na1313_full.html 


\section{Glossary}

aesthetics Generally, the study, science, or philosophy dealing with beauty. In scenery management, it describes landscapes that give visual and sensory pleasure.

axis A straight line, real or imaginary, passing through the center of a landscape such that each half is symmetrical.

background The landscape area located from 5 miles to infinity from the viewer. (The Bureau of Land Management, 1984, considers the background distance zone as the visible area usually from a minimum of 3-5 miles to a maximum of about 15 miles).

caliche thickness and maximum carbonate stage Caliche coatings may be detrimental to the strength of concrete if the bond of the cement paste to the coating is greater than the bond of the coating to the aggregate. However, caliche may not affect the aggregate/matrix bond if it is strongly cemented to the gravel, or if it is broken from the surface of the aggregate during crushing and processing. The presence of caliche may increase the amount of fines in the final product due to attrition during processing.

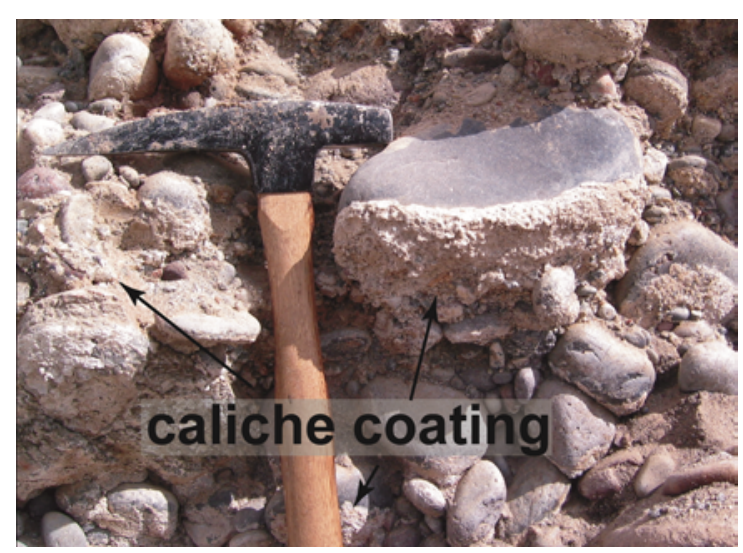

Maximum carbonate stage refers to the degree of coating or cementation of particles by $\mathrm{CaCO}_{3}$ (caliche) in gravel (Birkeland, 1999). Calcium carbonate $\left(\mathrm{CaCO}_{3}\right)$ at stages III and IV may cement gravel into large blocks or layers, thus complicating the excavation and processing of aggregate.

canopied A landscape type where features create a ceiling or canopy effect.

co-dominance Two major landscape form features that are nearly identical.

color The property of reflecting light of a particular wavelength that enables the eye to differentiate objects even though they have identical form, line, and texture. A hue (red, green, blue, yellow, and so on), as contrasted with a value (black, white, or gray).

contrast Diversity or distinction of adjacent parts in a landscape. Contrast has the effect of creating striking differences in form, line, color, or texture of a landscape.

convergence A landscape factor that tends to focus attention on one point or small area. 
cultural modification Any human-caused change in the land form, water form, vegetation, or the addition of a structure which creates a visual contrast in the basic elements of the naturalistic character of a landscape.

digitate edge The complex indented edge between two interlocking and contrasting areas.

disturbance A discrete event, either natural or human-induced, that causes a change in the existing condition of an ecological system.

edge The line where an object or area begins or ends. Edge serves to define borders, limits, or boundaries.

enclosed A landscape type with elements that form walls and floor.

enframement A landscape factor created when features in the landscape direct the viewer's attention inwards like the frame of a picture.

feature A landscape type dominated by a feature or a group of feature objects in the distance to which the eye is drawn.

focal A landscape type where the eye is led to a focal point in the landscape.

form Structure, mass, or shape of a landscape or of an object.

foreground The landscape area generally located from the viewer to $1 / 2$ mile away (U.S. Forest Service, 1995). The Bureau of Land Management considers the foregroundmiddle ground distance zone as the area visible from a travel route, use area, or other observation point to a distance of 3 to 5 miles (Bureau of Land Management, 1984).

gravel thickness The thickness of gravel varies throughout an area because of variations in the surface of the bedrock at the base of the gravel, variations in the thickness of overburden, and variations in the land surface. The thickness of the gravel is a judgment value based on observations at the pit face and natural exposures along terrace edges, stream banks, and so forth. The greater the overburden-to-gravel ratio, the more expensive it will be to mine the gravel.

harmony Combination of parts of a landscape into a pleasing or orderly whole.

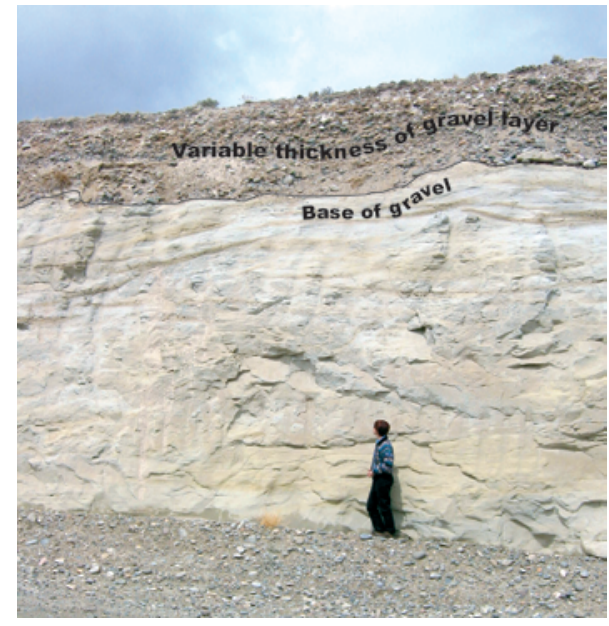

in Abbreviation for inch.

landform One of the attributes or features that make up the Earth's surface, such as plain, mountain, or valley. 
landscape character The overall impression created by a landscape's unique combination of visual features.

line An intersection of two planes; a point that has been extended; a silhouette of form. The path may be real or imagined in a landscape.

Los Angeles abrasion test The Los Angeles abrasion test is a measure of degradation of aggregate resulting from abrasion, impact, and grinding. The testing method is described in ASTM C535 and C131.

A sample of standard gradations of aggregate is placed in a rotating steel drum containing

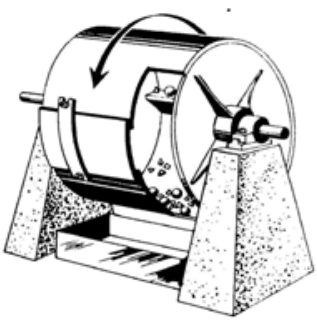
a specified number of steel spheres. As the drum rotates, a shelf picks up the aggregate and spheres and drops them to the other side of the drum. After a prescribed number of revolutions, the contents are sieved to measure degradation as percent loss (American Society of Testing and Materials, 2003). Consequently, the higher the test value, the higher the percent loss, and the lower the strength of the rock.

Rocks with LA values in the 20s commonly have the necessary strength properties for aggregate. Many specifications accept aggregate with an L.A. value of less than 30 .

maximum weathering Maximum particle weathering refers to degree of alteration and disintegration of particles in gravel (Birkeland, 1999). Stage 1, minor pitting or oxidation (rings sharply when struck by hammer); stage 2, moderate pitting, slight fracturing, and oxidation (solid sound when struck by hammer); stage 3, highly pitted, iron stains, strong fracturing (emits dull sound, broken with difficulty when struck by hammer); and stage 4 , strongly weathered and fractured, disintegrates easily (emits punky sound when struck by hammer).

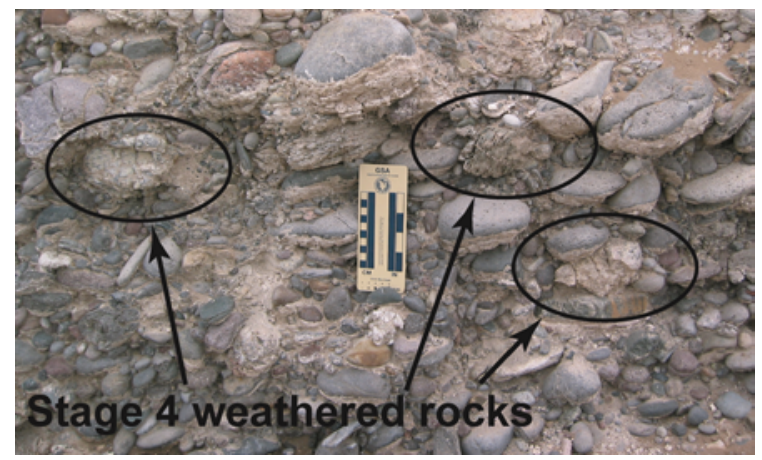

Rocks weathered to stage 4 commonly are not suitable for use as aggregate. However, weathered rock may be broken into smaller, unweathered particles during crushing and 
processing, thus increasing the amount of smaller particles in the final product, but not affecting the overall quality of the final product.

mesa A small, flat elevation with steep slopes on all sides.

mi Abbreviation for mile.

middle ground The zone between the foreground and the background in a landscape. The area is generally located from $1 / 2$ mile to 5 miles away.

overburden thickness Overburden is soil or other material other than gravel that overlies the gravel. Overburden must be stripped from the top of the gravel and removed from the site or stockpiled for future use in reclamation. The thickness of the gravel is a judgment value based on observations at the pit face and natural exposures along terrace edges, stream banks, and so forth.

Panorama A type of landscape in which breadth is the dominant characteristic and there are no apparent limits to the view.

particle size analysis Terrace gravels are composed of particles of various size and composition. Sand and gravel can be analyzed by size by sifting a dried and weighed sample through a set of testing sieves.

The testing method is described in ASTM C136.

A series of sieves are stacked upon on another, with the sieve with the largest openings on the top and the smallest opening on the bottom. A weighed and dried sample is placed on the top sieve. The stack of sieves is shaken by hand or mechanically.

The material that remains on each sieve is weighed, and is expressed as a percentage of the total sample.
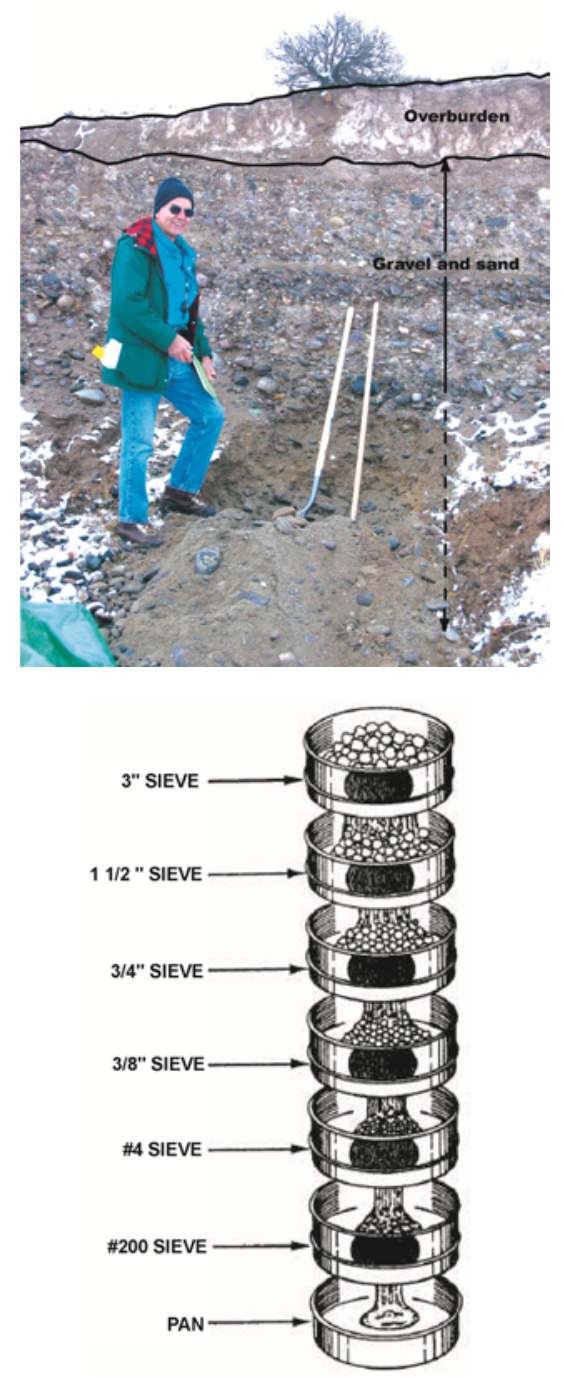

production constant-maximum recoverable product A common industry rule of thumb is that there are 2,420 tons of sand and gravel per acre per foot of gravel thickness. However, not all of that material is recoverable. Some is turned into waste during aggregate extraction and processing. Throughout the United States, about 5 percent of the total production of an aggregate operation consists of unmarketable waste (not including 
overburden) (Hudson and others, 1997). This is a minimum waste factor applied to aggregate in this study. This value can be adjusted based on experience gained during the processing of material.

The production constant was calculated using the following equation:

Maximum recoverable material $=(2,420$ tons per acre per foot $) \times($ thickness of deposit in feet) - (waste factor)

where:

thickness of deposit is unique to each site waste factor is 5 percent of the total tonnage

production constant-minimum recoverable product Gravel particles larger than 3 inches may be difficult to handle and crush. This material may be set aside and sold as rip rap, decorative stone, or other products. Furthermore, throughout the United States, about 23.8 percent of the total production of an aggregate operation consists of $-3 / 8$ in product (not including overburden) that is very difficult to market (Hudson and others, 1997). This constant calculates production from particles 3 in or less with a waste factor of 23.8 percent, assuming none of the $-3 / 8$ in material will be marketed. These values can be adjusted based on experience gained during the processing and marketing of material. The constant was calculated using the following equation:

Minimum recoverable material $=(2,420$ tons per acre per foot $) \times($ thickness of deposit in feet) - (percentage of sample $\geq 3$ inches) $x$ (waste factor) where:

thickness of deposit is unique to each site percentage of sample greater than or equal to 3 inches is unique to each site waste factor is 23.8 percent of the total tonnage

scale The proportionate size relationship between an object and the surroundings in which it is placed.

sequence A repetitious dominance of form, line, color, or texture.

soundness test This test provides an estimate of the ability of aggregates to resist alternate cycles of freezing and thawing or wetting and drying. The testing method is described in ASTM C88. Because the precision of this test method is poor it may not be suitable for rejection of aggregates without confirmation from other tests. Testing was performed by Inberg-Miller Engineers, Riverton, Wyo.

A set of weighed, sieved samples of specific particle sizes are alternately immersed in saturated solution of sodium or magnesium sulfate (sodium sulfate was used in these tests) and dried to precipitate salt in the permeable pore spaces. The internal forces derived from the hydration of salt simulate the expansion of water due to freezing. After a specified number of immersion and drying cycles, the material is put on the original sieve, and the material passing is measured as a percentage of the original sample. 
specific gravity and absorption This test is used to determine to provide an average value of the specific gravity (relative density) of the solid portion of a number of aggregate particles, not including the volume of voids in between the particles. The testing method is described in ASTM C127. Testing was performed by Inberg-Miller Engineers, Riverton, Wyo.

A sample of aggregate is immersed in water to fill the pores, the water is dried from the surface of the particles, and the sample weighed. The saturated sample then is weighed while submerged in water. Finally the sample is oven dried and weighed.

Specific gravity is calculated using the following equation:

Specific gravity = weight of dry sample-(weight of dry sample-weight of saturated sample in water)

Absorption is calculated using the following equation:

Absorption $=$ (weight of saturated sample-weight of dry sample) $/$ weight of dry sample .

texture A property of surface deriving from the material of which it is composed, chiefly apprehended by the manner in which it reflects light.

topography The general configuration of varying heights that give shape to Earth's surface.

visual resources The visible physical features on a landscape (for example, land, water, vegetation, animals, structures, and other features). 
Appendix A-Data Sheets Describing Geologic, Engineering, and Visual Assessment Observations 
This page intentionally left blank.

A-1 


\section{Site Name: Airport}

Location: NW 1/4, SW 1/4, S8, T1N, R4E, Wind River Meridian

USGS Topographic Sheet: Riverton West

Date: 20 April 2005

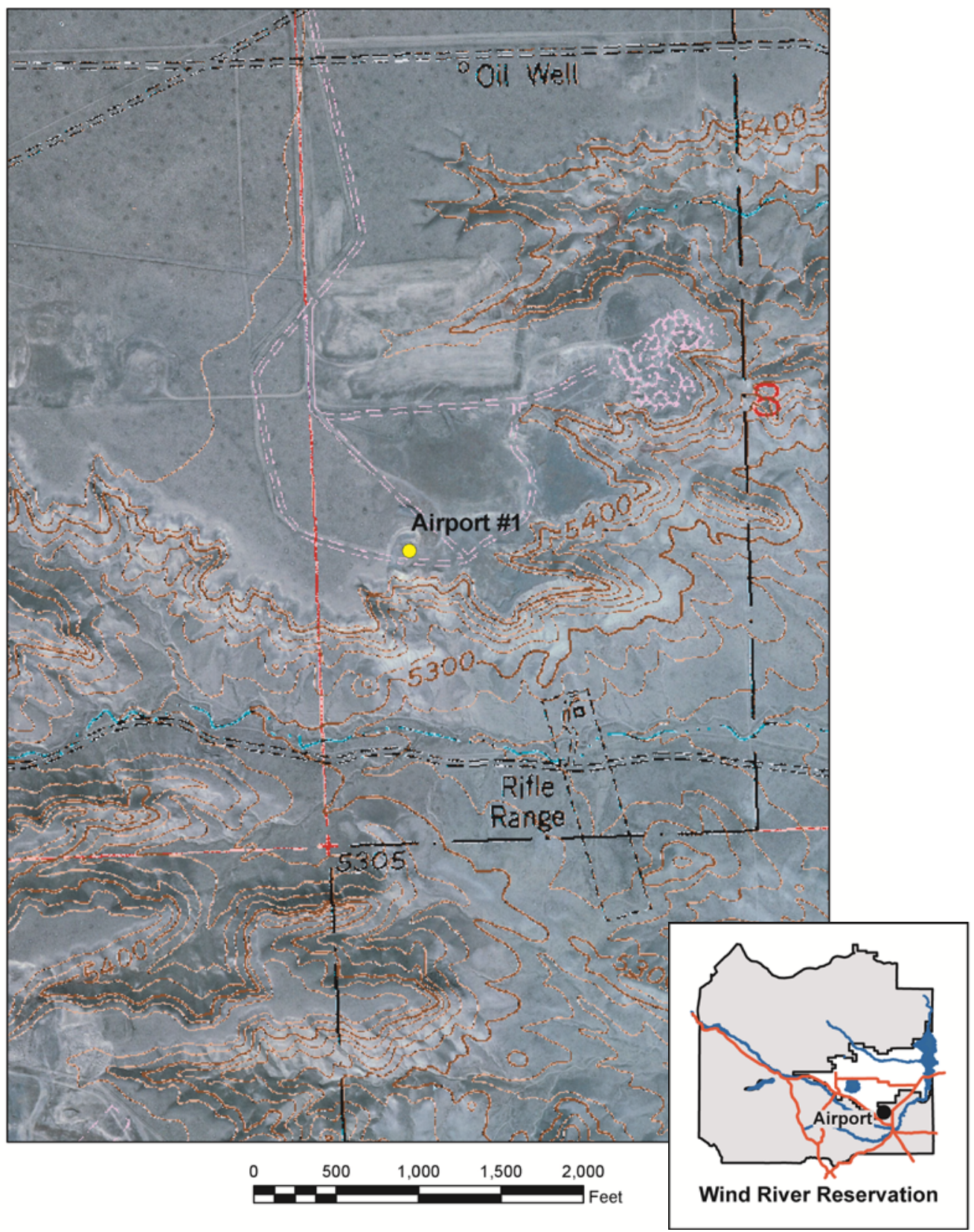




\begin{tabular}{|c|c|}
\hline \multicolumn{2}{|c|}{ GEOLOGIC DESCRIPTION } \\
\hline Sample number & $\# 1$ \\
\hline Location & $\begin{array}{c}43^{\circ} 04^{\prime} 29.5^{\prime \prime} \\
108^{\circ} 26^{\prime} 15.0^{\prime \prime}\end{array}$ \\
\hline Terrace level Qt & 10 \\
\hline Gravel thickness (feet) & 20 \\
\hline $\begin{array}{l}\text { Overburden thickness } \\
\text { (feet) }\end{array}$ & 2 \\
\hline Water table & None observed \\
\hline $\begin{array}{l}\text { Caliche thickness } \\
\text { (feet) }\end{array}$ & $6-7$ \\
\hline $\begin{array}{l}\text { Maximum carbonate } \\
\text { stage: }\end{array}$ & III \\
\hline $\begin{array}{l}\text { Maximum clast } \\
\text { weathering }\end{array}$ & 4 \\
\hline Lithologies (pct) & \\
\hline Granite-gneiss & 28 \\
\hline $\begin{array}{l}\text { Mafic plutonic- } \\
\text { metamorphic }\end{array}$ & 4 \\
\hline Quartzite & 43 \\
\hline Vein quartz & - \\
\hline Sandstone & Trace \\
\hline Limestone & Trace \\
\hline Chert & Trace \\
\hline Volcanics & 25 \\
\hline Total & 100 \\
\hline
\end{tabular}

\begin{tabular}{|c|c|}
\hline \multicolumn{2}{|c|}{ ENGINEERING TESTS } \\
\hline Sample number & $\# 1$ \\
\hline $\begin{array}{l}\text { Maximum clast size } \\
\text { (inches) }\end{array}$ & Cobble \\
\hline \multicolumn{2}{|c|}{ Size distribution (percent) } \\
\hline Cobbles & 27 \\
\hline Coarse Gravel & 34 \\
\hline Fine Gravel & 18 \\
\hline Sand & 21.3 \\
\hline Fines & 0.7 \\
\hline Total & $101^{*}$ \\
\hline LA Value & 22.6 \\
\hline \multicolumn{2}{|l|}{ Soundness } \\
\hline$\leq 1.5^{\prime \prime}->0.75^{\prime \prime}$ & 0.1 \\
\hline$\leq 0.75 "$ - >0.375" & 0.2 \\
\hline$\leq 0.375->\# 4$ sieve & 0.1 \\
\hline Specific gravity & 2.575 \\
\hline Percent absorption & 1.2 \\
\hline
\end{tabular}

* Numbers do not add to 100 due to rounding

\begin{tabular}{|l|c|}
\hline PRODUCTION CONSTANT & 20 \\
\hline Estimated gravel thickness (feet) & 45,980 \\
\hline Constant - Maximum recoverable product (tons per acre) & 26,923 \\
\hline Constant - Minimum recoverable product (tons per acre) & \\
\hline CONCLUSIONS & \\
\hline Portland cement concrete - May be suitable. Will require crushing and screening and may require \\
washing. Determine susceptibility to alkali-silica reaction. May require use of low-alkali cement or \\
additives. \\
Asphalt concrete - Suitable. Will require crushing and screening. \\
Base - Suitable. Will require crushing and screening. \\
Deleterious Material - Large amount of calcium carbonate (caliche) coating. Crushing will reduce \\
extent of coating.
\end{tabular}




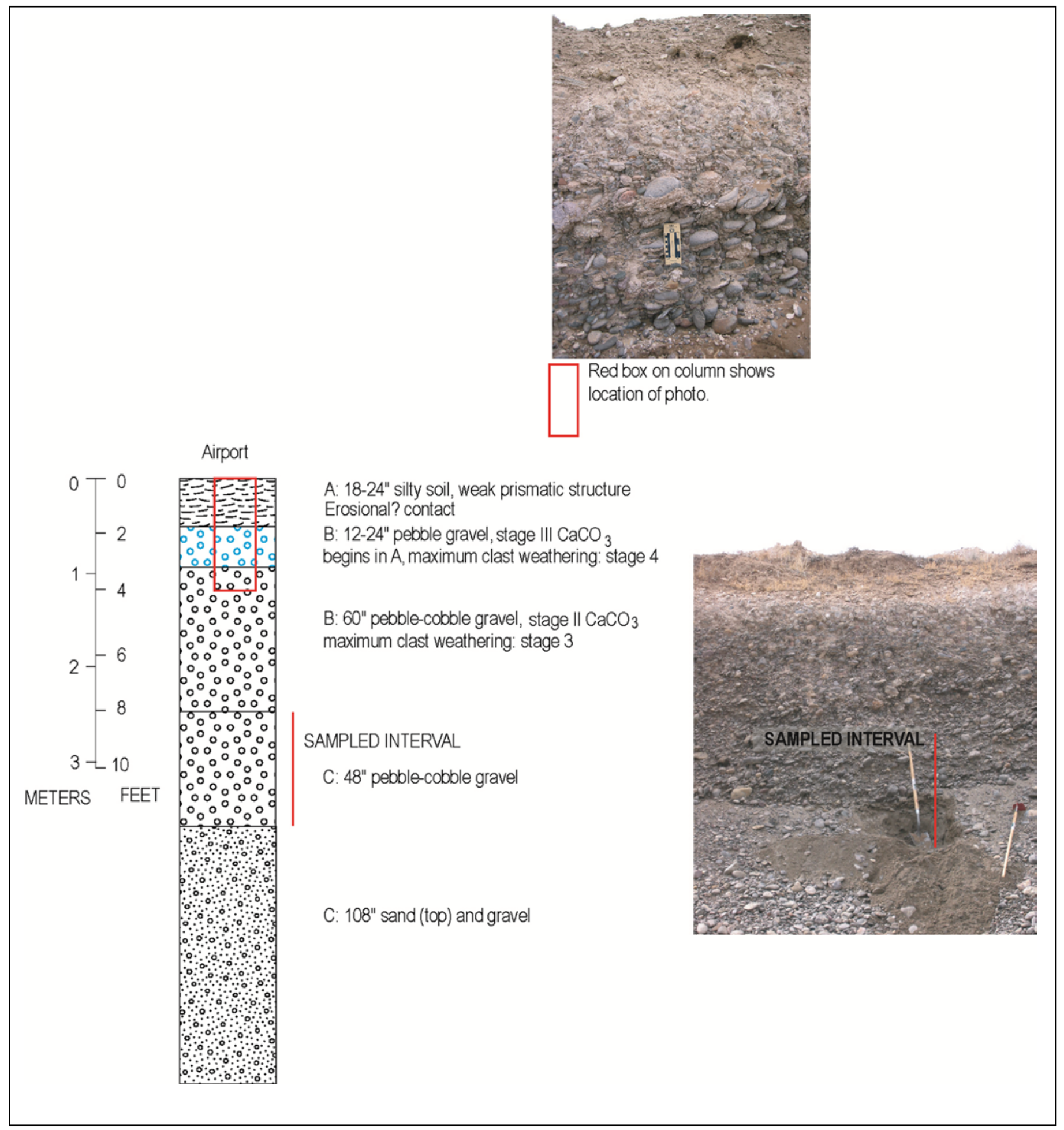




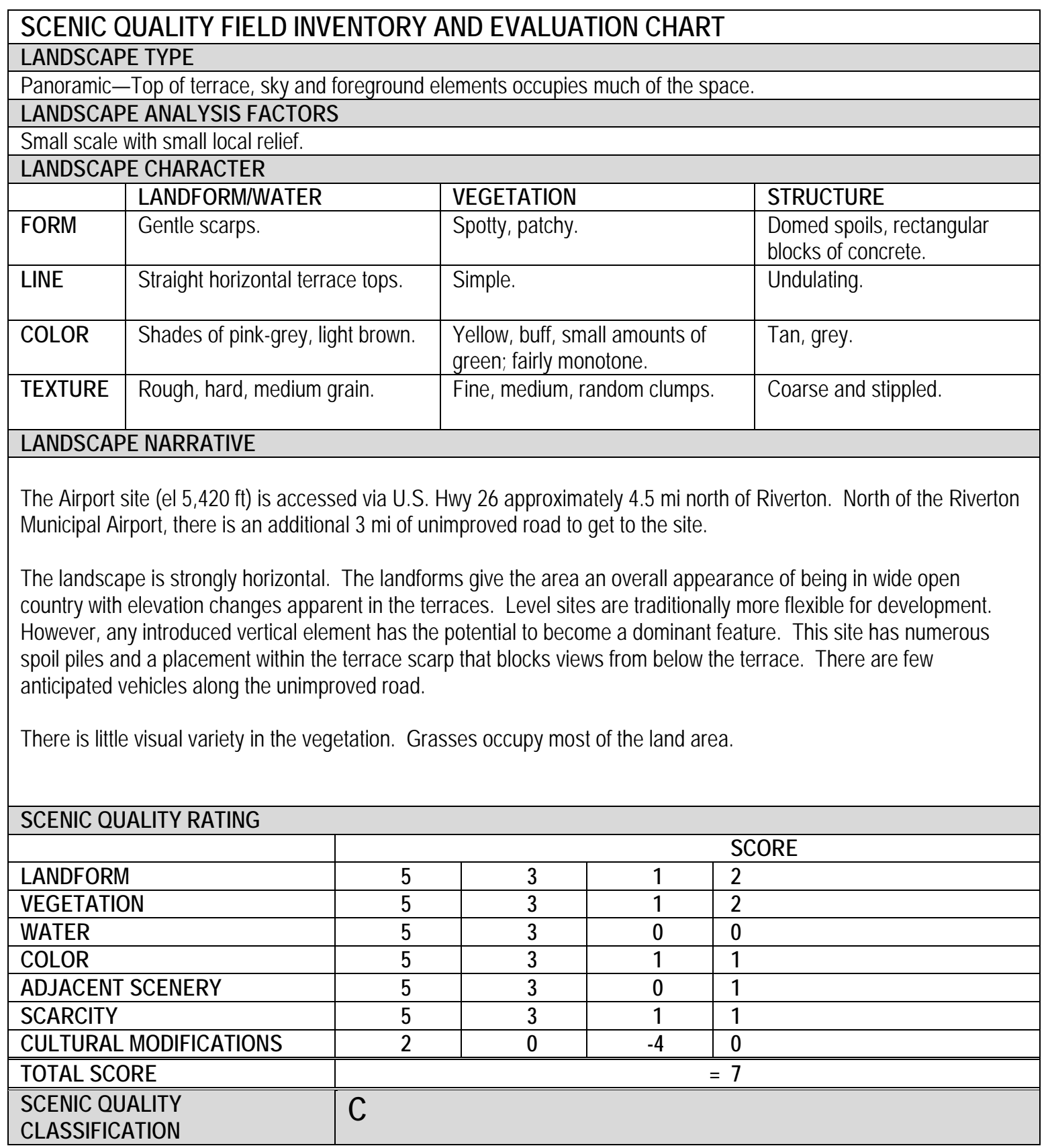




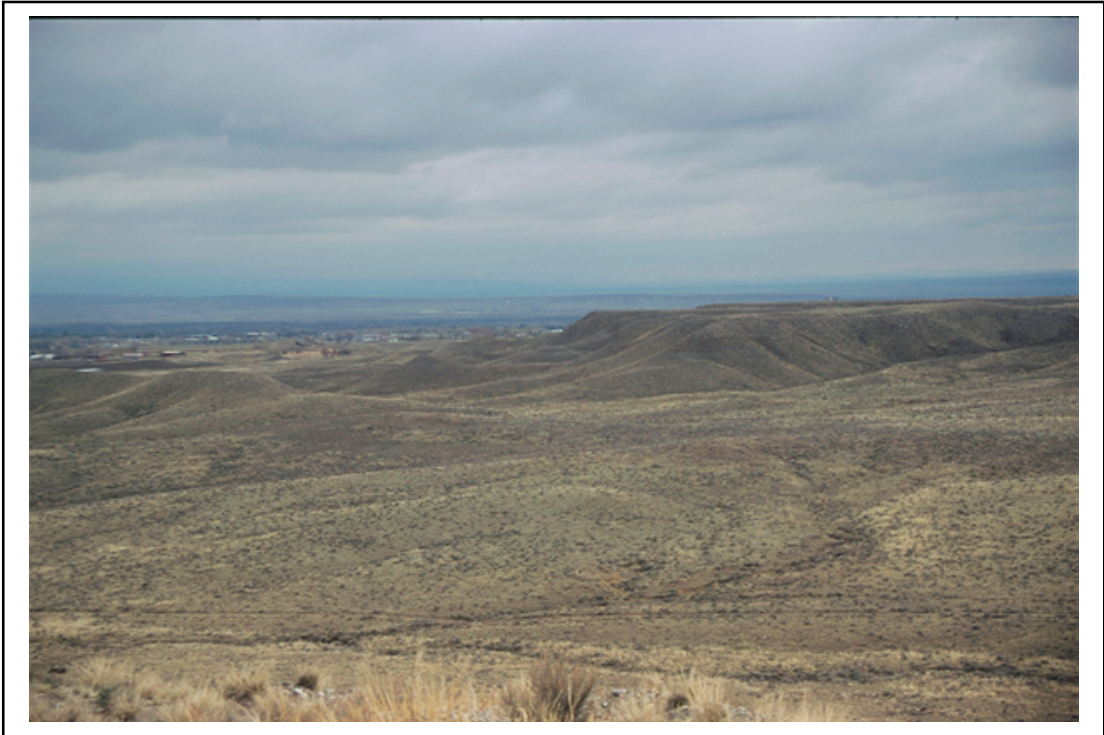

Upper, Large tracts of grassland and stream terraces are visible in this southeastoriented view from the Airport site. Lower, Photo from within site showing concrete drainage slabs from canal work are saved for recycling. Sand and gravel spoils surround the pit area.

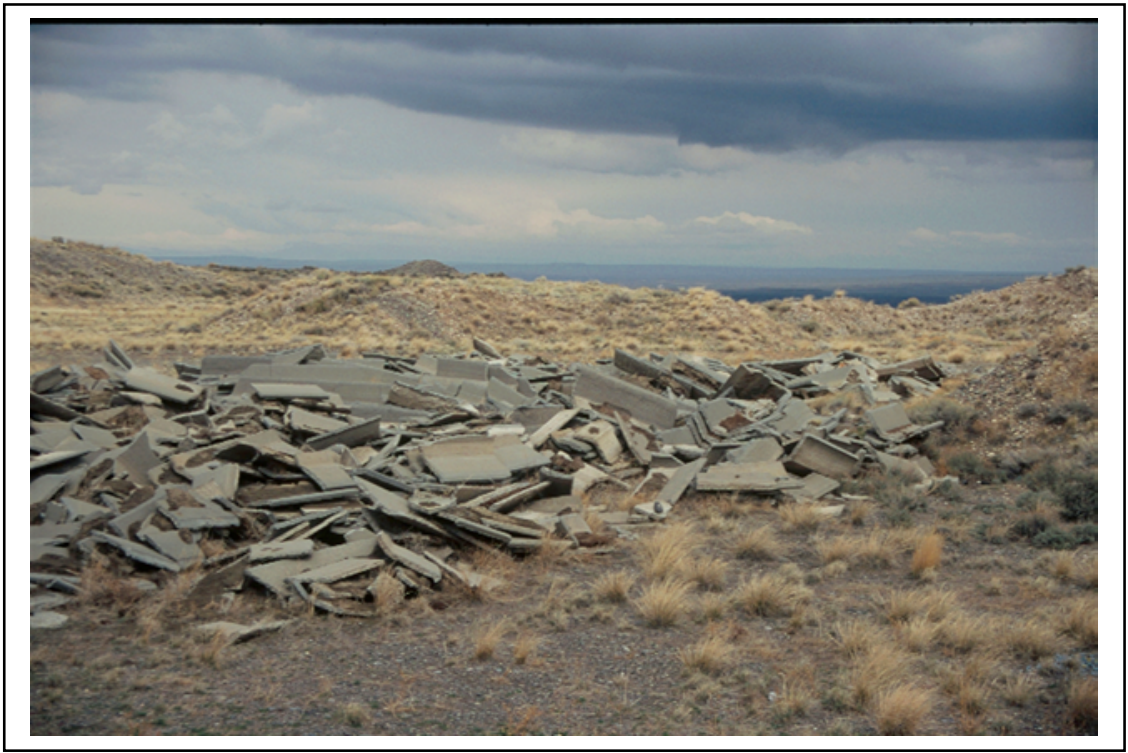


This page intentionally left blank. 


\section{Site Name: Burma Hill}

Location: SW 1/4, SW 1/4, S22, T2N, R4E, Wind River Meridian

USGS Topographic Sheet: Lost Wells Butte

Date: 20 April 2005

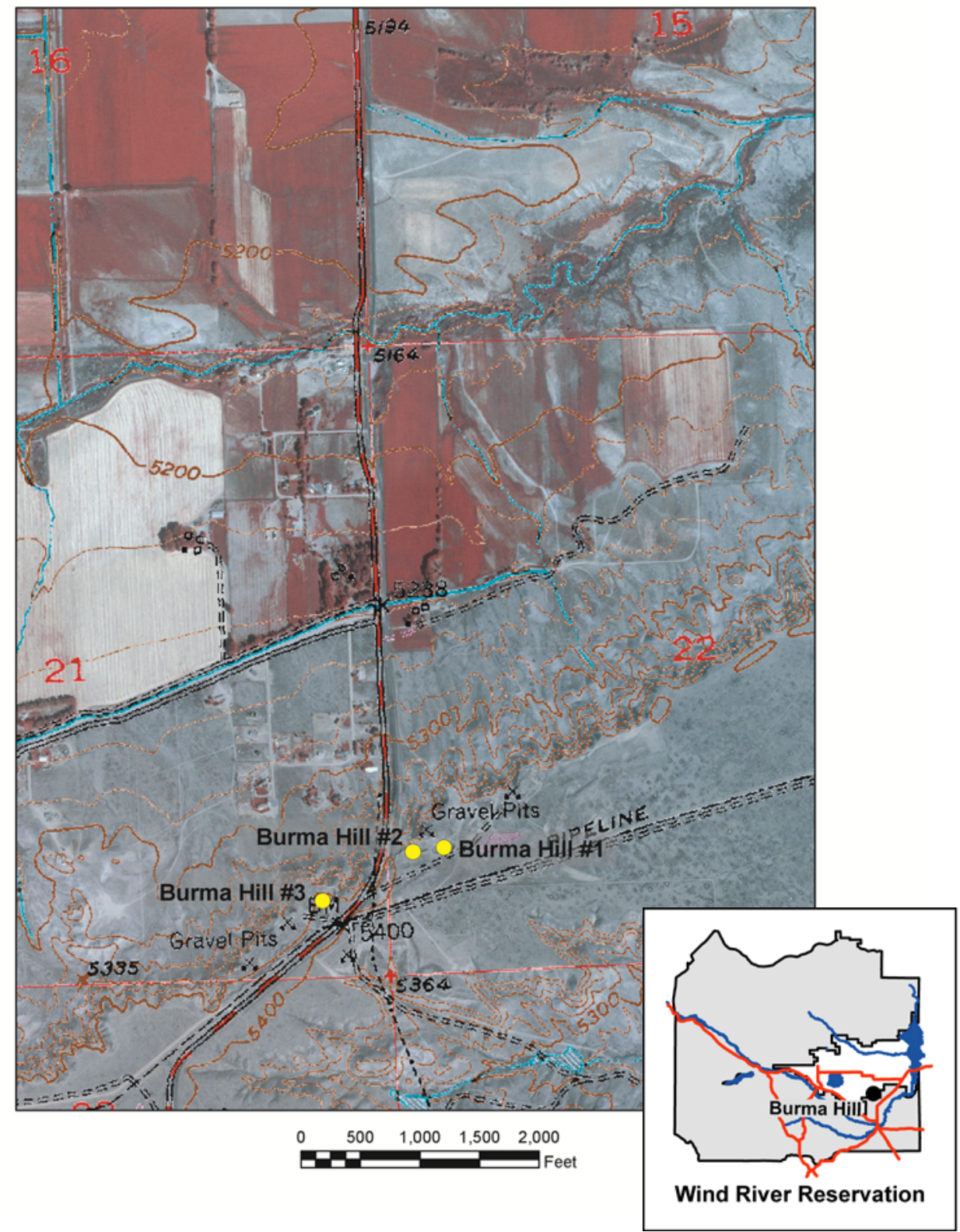




\begin{tabular}{|c|c|c|c|c|}
\hline \multicolumn{5}{|c|}{ GEOLOGIC OBSERVATIONS } \\
\hline Sample number & $\# 1$ & $\# 2$ & $\# 3$ & \multirow{2}{*}{$\begin{array}{c}\text { General site } \\
\text { characteristics }\end{array}$} \\
\hline Location & $\begin{array}{c}43^{\circ} 07^{\prime} 52.5^{\prime \prime} \\
108^{\circ} 23^{\prime} 54.5^{\prime \prime} \\
\end{array}$ & $\begin{array}{c}43^{\circ} 07^{\prime} 52.2^{\prime \prime} \\
108^{\circ} 23^{\prime} 58.0^{\prime \prime} \\
\end{array}$ & $\begin{array}{c}43^{\circ} 07^{\prime} 48.4^{\prime \prime} \\
108^{\circ} 24^{\prime} 08.4^{\prime \prime} \\
\end{array}$ & \\
\hline Terrace level Qt & 10 & 10 & 10 & 10 \\
\hline Gravel thickness (feet) & 9 & 5 & 8 & 8 \\
\hline $\begin{array}{l}\text { Overburden thickness } \\
\text { (feet) }\end{array}$ & 2 & 6 & 2 & 2 \\
\hline Water table & None observed & None observed & None observed & None observed \\
\hline $\begin{array}{l}\text { Caliche thickness } \\
\text { (feet) }\end{array}$ & 2 & 3 & 1 & 2 \\
\hline $\begin{array}{l}\text { Maximum carbonate } \\
\text { stage: }\end{array}$ & III & III & III & III \\
\hline $\begin{array}{l}\text { Maximum clast } \\
\text { weathering }\end{array}$ & 4 & 3 & 3 & 4 \\
\hline \multicolumn{5}{|l|}{ Lithologies (pct) } \\
\hline Granite-gneiss & 33 & 31 & 26 & 30 \\
\hline $\begin{array}{l}\text { Mafic plutonic- } \\
\text { metamorphic }\end{array}$ & 13 & 10 & 7 & 10 \\
\hline Quartzite & 23 & 23 & 17 & 21 \\
\hline Vein quartz & - & 2 & 6 & 3 \\
\hline Sandstone & 4 & 5 & 6 & 5 \\
\hline Limestone & - & - & Trace & Trace \\
\hline Chert & 5 & 3 & 1 & 3 \\
\hline Volcanics & 22 & 25 & 37 & 28 \\
\hline Total & 100 & $99^{*}$ & 100 & 100 \\
\hline
\end{tabular}

* Numbers do not add to 100 due to rounding 


\begin{tabular}{|c|c|c|c|c|}
\hline \multicolumn{5}{|c|}{ ENGINEERING TESTS } \\
\hline Sample number & $\# 1$ & $\# 2$ & $\# 3$ & $\begin{array}{c}\text { General site } \\
\text { characteristics }\end{array}$ \\
\hline \multicolumn{5}{|l|}{ Grain Size Analysis } \\
\hline $\begin{array}{l}\text { Maximum clast size } \\
\text { (inches) }\end{array}$ & 6 & 6 & 6 & 6 \\
\hline \multicolumn{5}{|c|}{ Size distribution (percent) } \\
\hline Cobbles & 5 & 3 & 11 & 6 \\
\hline Coarse Gravel & 38 & 34 & 44 & 39 \\
\hline Fine Gravel & 20 & 20 & 12 & 17 \\
\hline Sand & 34.4 & 39.4 & 30.8 & 34.9 \\
\hline Fines & 2.6 & 3.6 & 2.2 & 2.8 \\
\hline Total & 100 & 100 & 100 & $99.7^{*}$ \\
\hline LA Value & 27.4 & 25.6 & 26.4 & 26.5 \\
\hline \multicolumn{5}{|l|}{ Soundness } \\
\hline$\leq 1.5^{\prime \prime}->0.75^{\prime \prime}$ & 1.6 & 0.4 & 1.4 & 1.1 \\
\hline$\leq 0.75^{\prime \prime}->0.375^{\prime \prime}$ & 0.7 & 0.4 & 0.2 & 0.4 \\
\hline$\leq 0.375$ - >\#4 sieve & 0.2 & 0.4 & 0.3 & 0.3 \\
\hline Specific gravity & 2.533 & 2.527 & 2.572 & 2.544 \\
\hline Percent absorption & 1.6 & 1.8 & 1.3 & 1.6 \\
\hline
\end{tabular}

${ }^{*}$ Numbers do not add to 100 due to rounding

\section{PRODUCTION CONSTANT}

Estimated gravel thickness (feet)

Constant - Maximum recoverable product (tons per acre)

Constant - Minimum recoverable product (tons per acre)

18,392

CONCLUSIONS

Portland cement concrete - May be suitable. Will require crushing and screening and may require washing. Determine susceptibility to alkali-silica reaction. May require use of low-alkali cement or additives.

Asphalt concrete - Suitable. Will require crushing and screening.

Base - Suitable. Will require crushing and screening.

Specific gravity - May be marginally acceptable. 
BURMA HILL: Sheet 4 of 9
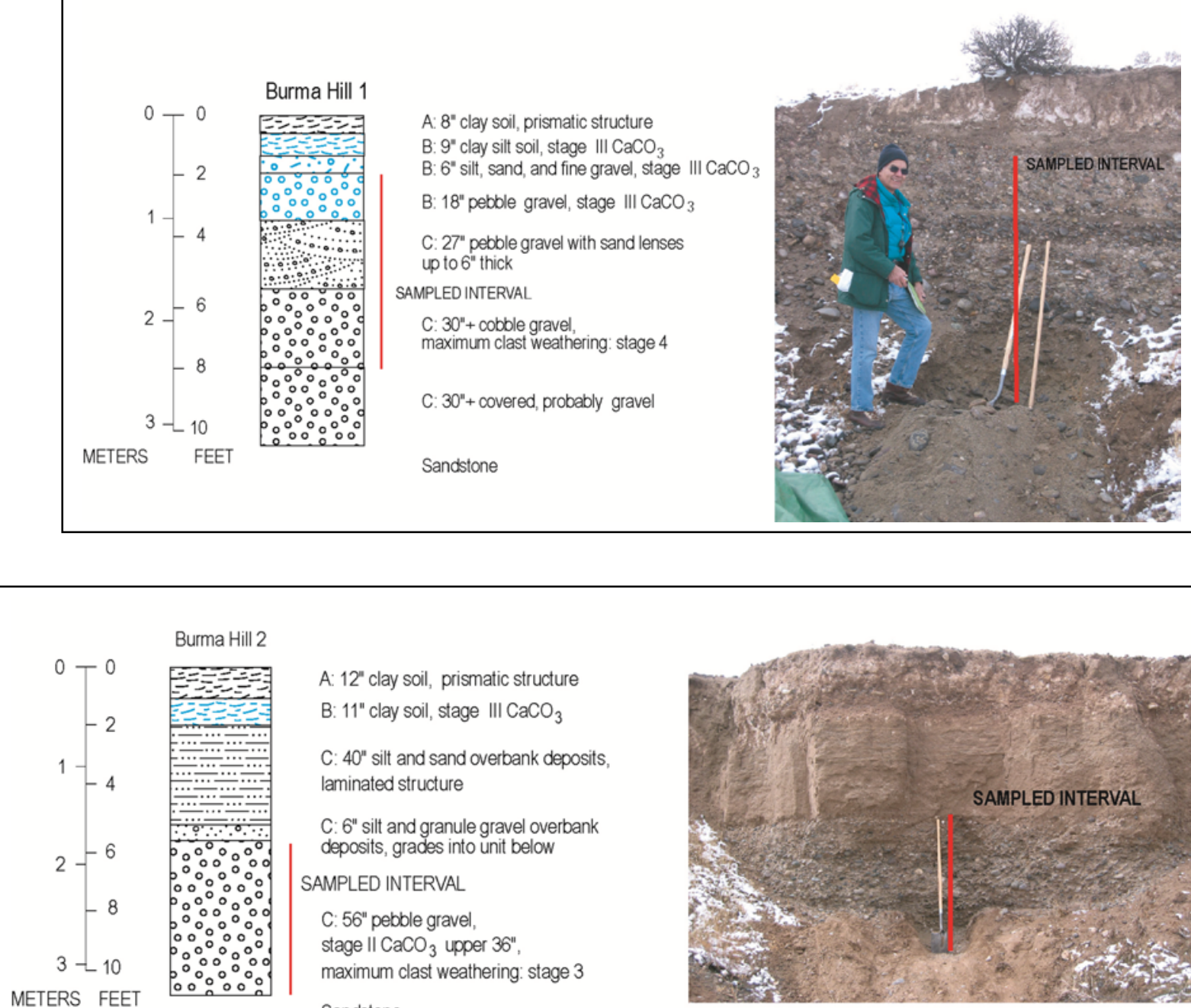

A: 12 " clay soil, prismatic structure

B: 11 " clay soil, stage $1 \mathrm{II} \mathrm{CaCO}_{3}$

C: 40 " silt and sand overbank deposits, laminated structure

C: 6" silt and granule gravel overbank deposits, grades into unit below

SAMPLED INTERVAL

C: 56 " pebble gravel,

stage $1 / \mathrm{CaCO}_{3}$ upper $36 "$ ",

maximum clast weathering: stage 3

Sandstone

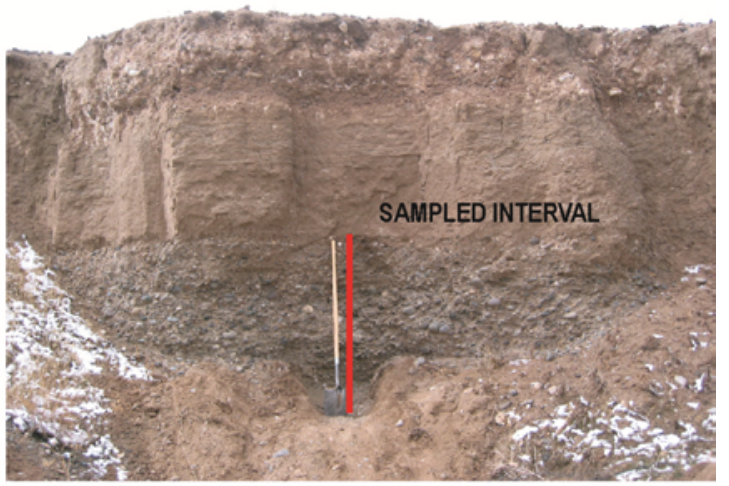

Burma Hill 3

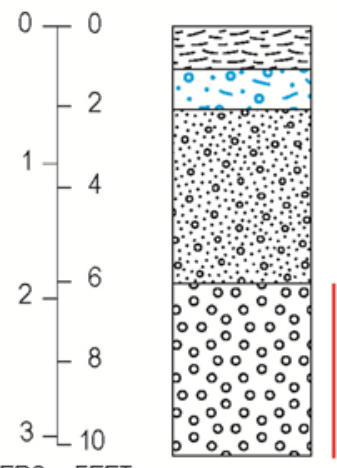

A: 12 " clay soil

B: 12 " silt, sand, and fine gravel, stage $\mathrm{III} \mathrm{CaCO}_{3}$

C: $50 "$ pebble gravel with sand lenses, stage $\mathrm{ICaCO}_{3}$ in lower $12 "$ maximum clast weathering: stage 3

SAMPLED INTERVAL

C: 50 " cobble gravel with sand lenses

Sandstone

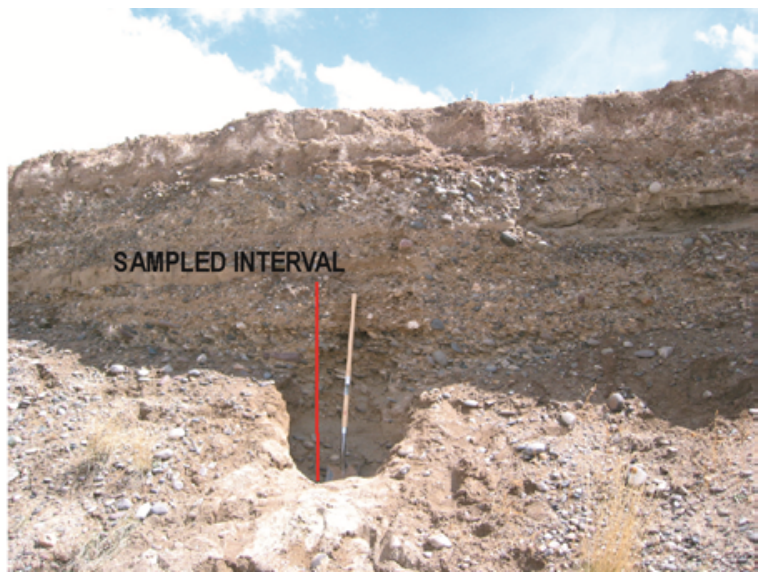


BURMA HILL: Sheet 5 of 9

This page intentionally left blank. 


\begin{tabular}{|c|c|c|c|c|c|}
\hline \multicolumn{6}{|c|}{ SCENIC QUALITY FIELD INVENTORY AND EVALUATION CHART } \\
\hline \multicolumn{6}{|c|}{ LANDSCAPE TYPE } \\
\hline \multicolumn{6}{|c|}{ Feature-Dominated by a distant butte and riparian areas. } \\
\hline \multicolumn{6}{|c|}{ LANDSCAPE ANALYSIS FACTORS } \\
\hline \multicolumn{6}{|c|}{ Repetitious dominance of line from landform, vegetation, and road. Lines tend to converge. } \\
\hline \multicolumn{6}{|c|}{ LANDSCAPE CHARACTER } \\
\hline & \multirow{2}{*}{\multicolumn{2}{|c|}{$\begin{array}{l}\text { LANDFORM/WATER } \\
\text { Gentle slope in foreground; steep } \\
\text { vertical at far edge of middle ground. }\end{array}$}} & \multicolumn{2}{|c|}{ VEGETATION } & STRUCTURE \\
\hline FORM & & & \multicolumn{2}{|c|}{ Patchy, cushion. } & $\begin{array}{l}\text { Rectangular, cylindrical, } \\
\text { simple. }\end{array}$ \\
\hline LINE & \multicolumn{2}{|c|}{$\begin{array}{l}\text { Broken horizontal skyline, dominant } \\
\text { ridgeline. }\end{array}$} & & $\begin{array}{l}\text { Linear road, vertical } \\
\text { (telephone poles, barbed wire } \\
\text { fence). }\end{array}$ \\
\hline COLOR & \multicolumn{2}{|c|}{ Tan, dark grey, red color in butte. } & \multicolumn{2}{|c|}{$\begin{array}{l}\text { Grey, celadon green, buff, } \\
\text { cream. }\end{array}$} & Brown, rust, grey, cream. \\
\hline TEXTURE & \multicolumn{2}{|c|}{ Medium and fine grain. } & \multicolumn{2}{|c|}{$\begin{array}{l}\text { Uneven and coarse shrubs; } \\
\text { fine grasses. }\end{array}$} & Ordered, asymmetrical. \\
\hline \multicolumn{6}{|c|}{ LANDSCAPE NARRATIVE } \\
\hline \multicolumn{6}{|c|}{$\begin{array}{l}\text { The Burma Hill site is bisected by Burma Road (Hwy } 320 \text { ) and is within } 9 \text { mi of Riverton. The elevation ranges from } \\
\text { approximately } 5,400 \mathrm{ft} \text { at the terrace tread to } 5,200 \mathrm{ft} \text { in Paradise Valley and Sand Gulch to the north. Riverton Valley } \\
\text { is to the south. Slope is gentle with views in the area containing foreground, middle ground, and background (Owl } \\
\text { Creek Mountains to the north). Sand Gulch (riparian area in the middle ground) and Lost Wells Butte (highest el } \\
5,675 \mathrm{ft} \text { ) are visible from the east side despite poor atmospheric conditions. Snow capped peaks are visible in the } \\
\text { distance on the west side. A low cloud ceiling and snowfall gives an overall softness to the landscape and mutes color. } \\
\text { Irrigated crop areas and human settlement are evident. The texture of the land is mostly fine. }\end{array}$} \\
\hline \multicolumn{6}{|c|}{$\begin{array}{l}\text { Big sagebrush and mixed-grass occupy the undisturbed land areas. For most of the year the landscape has a strong } \\
\text { grey color. The texture of the vegetation appears coarse in the foreground and fine in the middle ground. }\end{array}$} \\
\hline \multicolumn{6}{|c|}{$\begin{array}{l}\text { The eastern Burma Hill site is viewed from Burma Road for about } 17 \text { seconds heading south; the view is hidden } \\
\text { traveling north. The western Burma Hill site is screened in both directions from Burma Road. It is surrounded by } \\
\text { existing spoil piles and the view of the site is hidden from the valley floor. Cultural modifications both complement } \\
\text { (pastoral landscape) and detract (oil or gas development, telephone poles). Some trash was evident on the eastern } \\
\text { side. For this assessment, the modifications are rated as canceling each other out. }\end{array}$} \\
\hline \multicolumn{6}{|c|}{ SCENIC QUALITY RATING } \\
\hline \multirow{2}{*}{\multicolumn{2}{|c|}{ LANDFORM }} & & \multicolumn{3}{|c|}{ SCORE } \\
\hline & & 5 & 3 & 1 & \\
\hline \multicolumn{2}{|c|}{$\begin{array}{l}\text { LANDFORM } \\
\text { VEGETATION }\end{array}$} & 5 & 3 & 1 & \\
\hline \multicolumn{2}{|l|}{ WATER } & 5 & 3 & 0 & \\
\hline \multicolumn{2}{|l|}{ COLOR } & 5 & 3 & 1 & \\
\hline \multicolumn{2}{|c|}{ ADJACENT SCENERY } & 5 & 3 & 0 & \\
\hline \multicolumn{2}{|c|}{ SCARCITY } & 5 & 3 & 1 & \\
\hline \multicolumn{2}{|c|}{ CULTURAL MODIFICATIONS } & 2 & 0 & -4 & \\
\hline \multicolumn{2}{|c|}{ TOTAL SCORE } & \multicolumn{4}{|c|}{$=13$} \\
\hline \multicolumn{2}{|c|}{$\begin{array}{l}\text { SCENIC QUALITY } \\
\text { CLASSIFICATION }\end{array}$} & \multicolumn{4}{|l|}{ B } \\
\hline
\end{tabular}



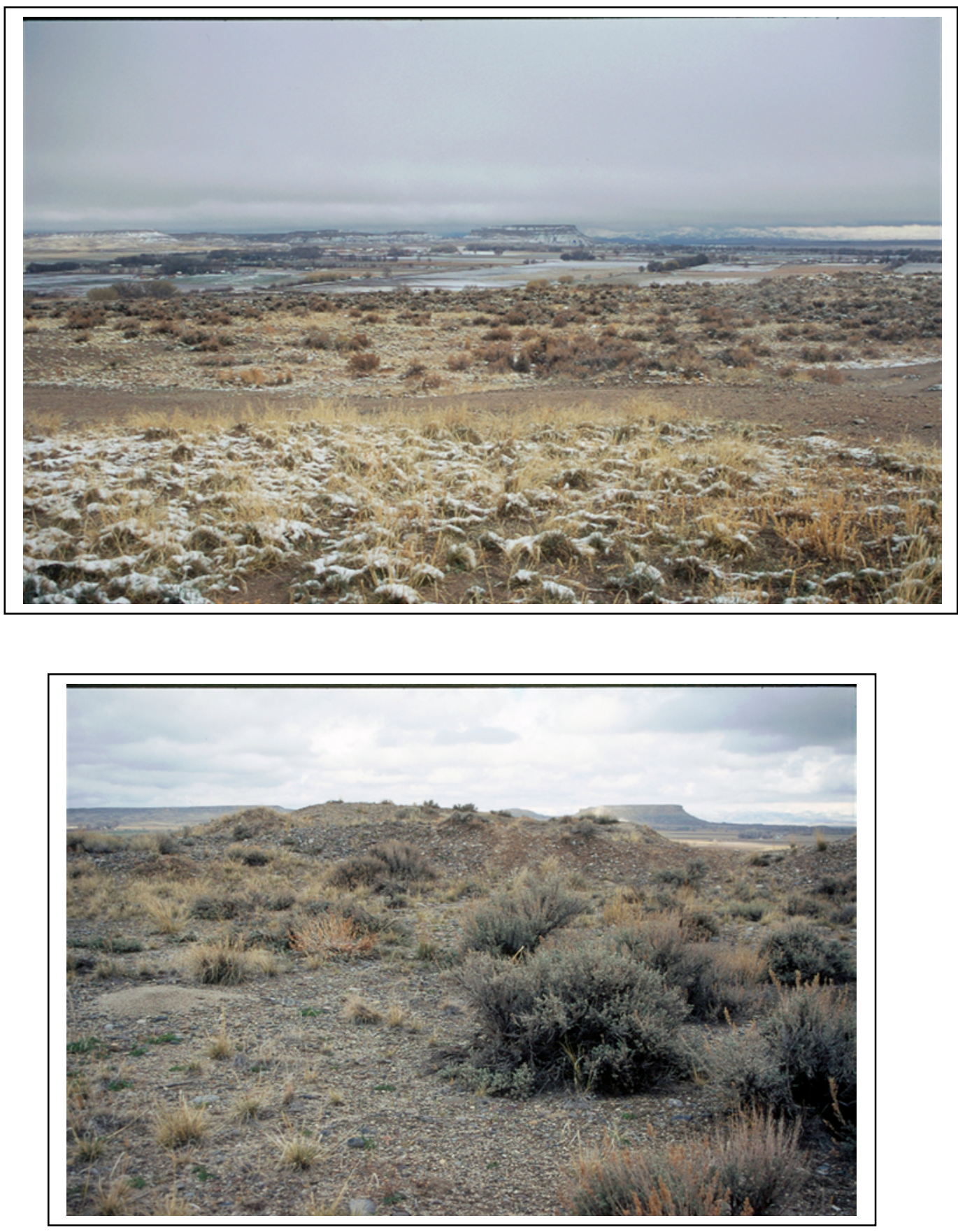

Upper, View north from eastern site at Burma Hill. Paradise Valley, riparian, and irrigated land cover are visible in the middle ground. Lower, View from western site at Burma Hill. Spoil piles and sand and gravel are visible on site. 
BURMA HILL: Sheet 8 of 9

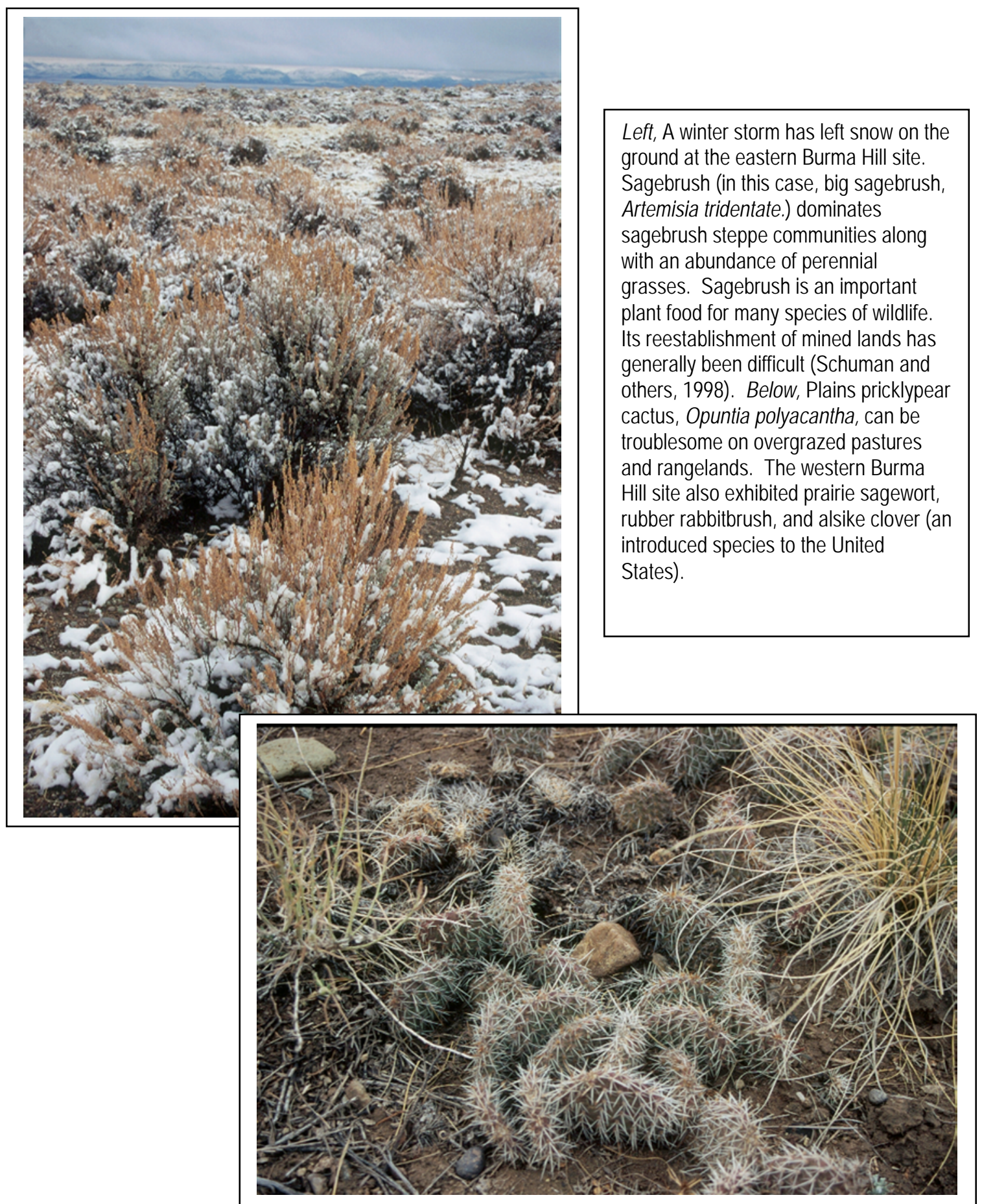


BURMA HILL: Sheet 9 of 9

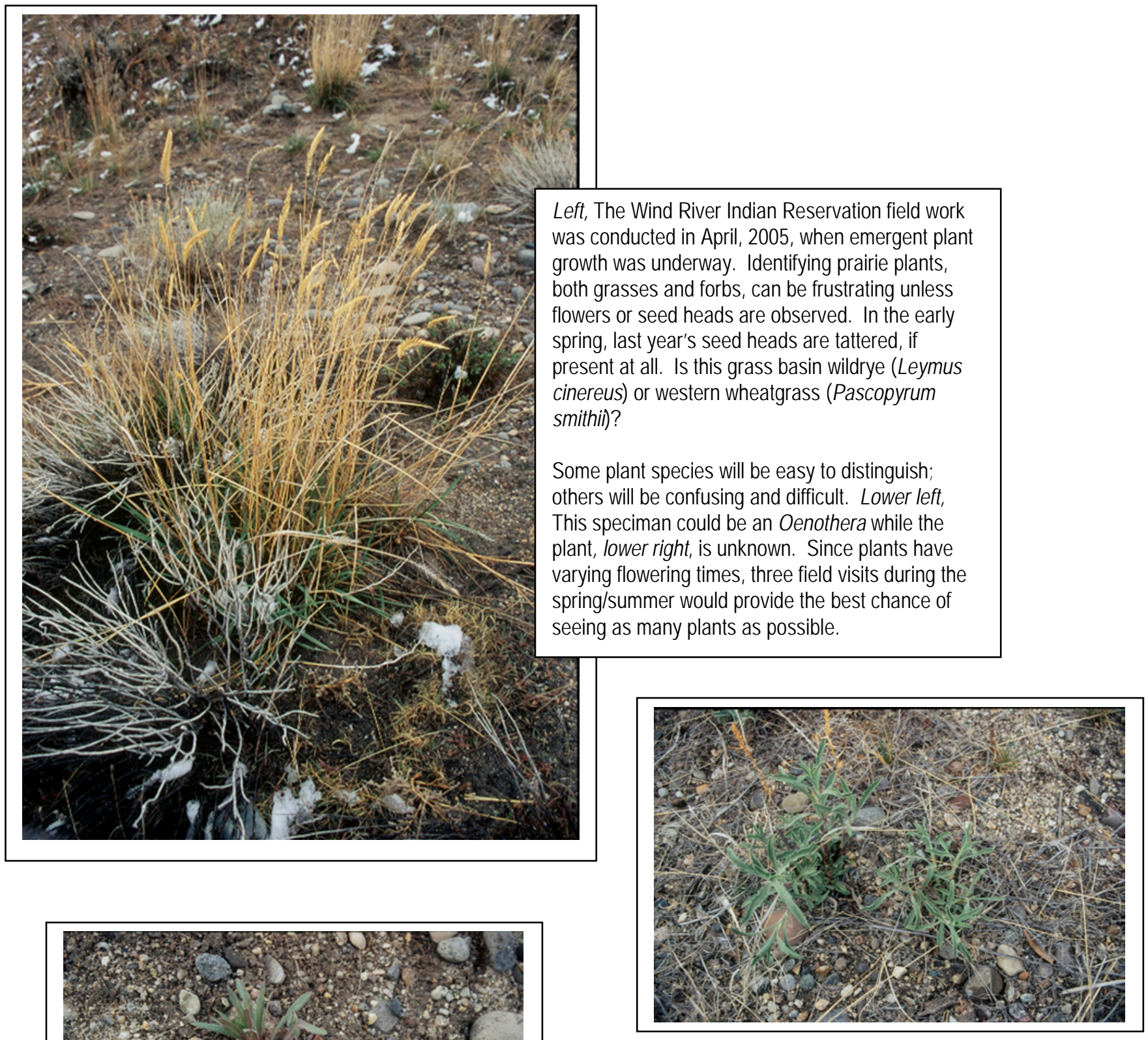


This page intentionally left blank. 


\section{Site Name: Crowheart Butte \#1}

Location: SE 1/4, SE 1/4, S8, T4N, R3W, Wind River Meridian USGS Topographic Sheet: Crowheart

Date: 22 April 2005

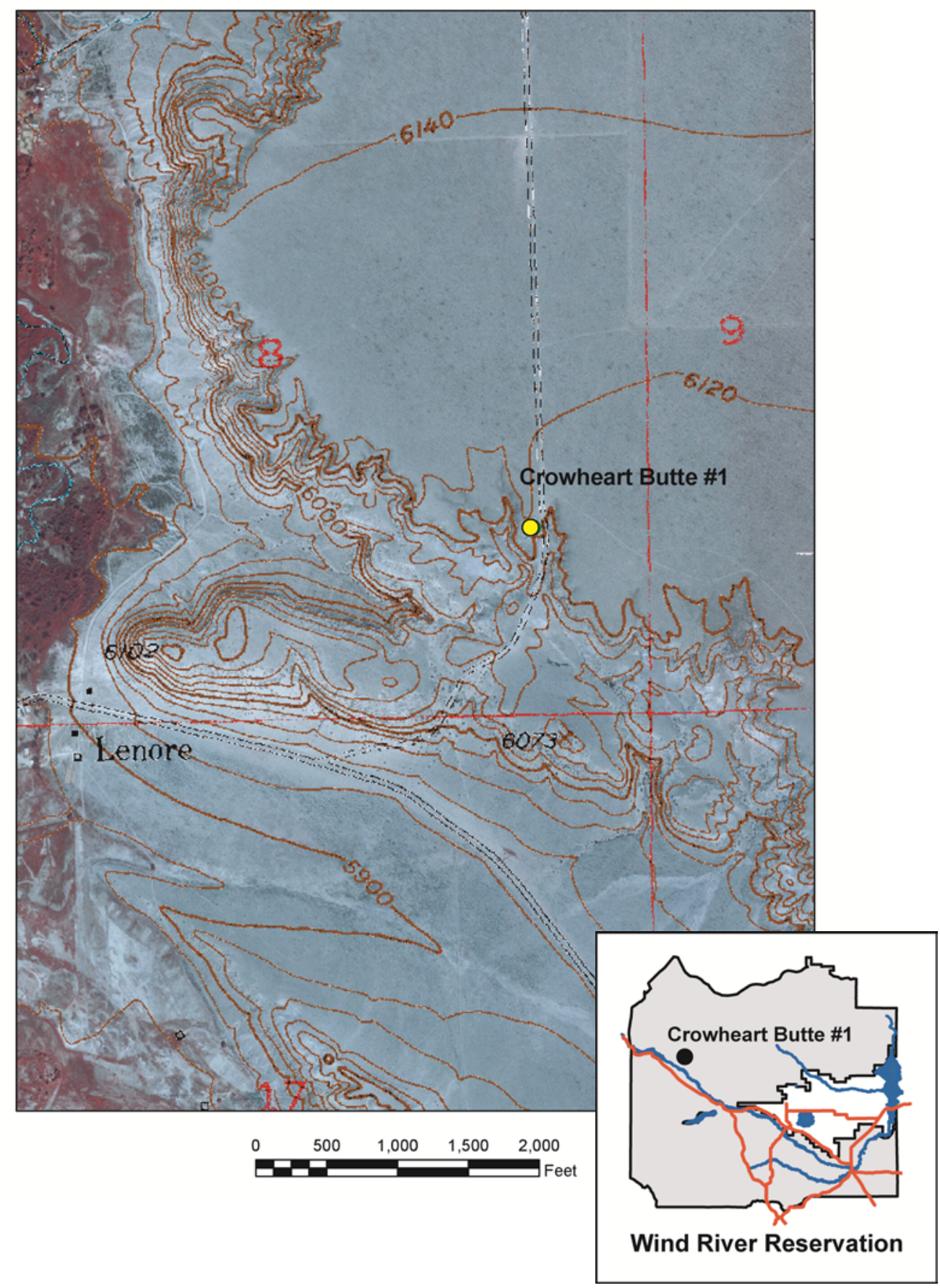


CROWHEART BUTTE \#1: Sheet 2 of 6

\begin{tabular}{|c|c|}
\hline \multicolumn{2}{|c|}{ GEOLOGIC DESCRIPTION } \\
\hline Sample number & \#1 \\
\hline Location & $\begin{array}{c}43^{\circ} 20^{\prime} 02.2^{\prime \prime} \\
109^{\circ} 07^{\prime} 57.7^{\prime \prime} \\
\end{array}$ \\
\hline Terrace level Qt & $8(?)$ \\
\hline Gravel thickness (feet) & $7-8$ \\
\hline $\begin{array}{l}\text { Overburden thickness } \\
\text { (feet) }\end{array}$ & $1-2$ \\
\hline Water table & None observed \\
\hline $\begin{array}{l}\text { Caliche thickness } \\
\text { (feet) }\end{array}$ & $2-3$ \\
\hline $\begin{array}{l}\text { Maximum carbonate } \\
\text { stage }\end{array}$ & III \\
\hline $\begin{array}{l}\text { Maximum clast } \\
\text { weathering }\end{array}$ & 4 \\
\hline \multicolumn{2}{|l|}{ Lithologies (pct) } \\
\hline Granite-gneiss & 21 \\
\hline $\begin{array}{l}\text { Mafic plutonic- } \\
\text { metamorphic }\end{array}$ & 5 \\
\hline Quartzite & 25 \\
\hline Vein quartz & - \\
\hline Sandstone & 12 \\
\hline Limestone & - \\
\hline Chert & 1 \\
\hline Volcanics & 36 \\
\hline Total & 100 \\
\hline
\end{tabular}

\begin{tabular}{|c|c|}
\hline \multicolumn{2}{|c|}{ ENGINEERING TESTS } \\
\hline Sample number & $\# 1$ \\
\hline $\begin{array}{l}\text { Maximum clast size } \\
\text { (inches) }\end{array}$ & $>3$ \\
\hline \multicolumn{2}{|c|}{ Size distribution (percent) } \\
\hline Cobbles & 4 \\
\hline Coarse Gravel & 36 \\
\hline Fine Gravel & 26 \\
\hline Sand & 31.8 \\
\hline Fines & 2.2 \\
\hline Total & 100 \\
\hline LA Value & 29.3 \\
\hline \multicolumn{2}{|l|}{ Soundness (pct) } \\
\hline$\leq 1.5^{\prime \prime}->0.75^{\prime \prime}$ & 1.0 \\
\hline$\leq 0.75^{\prime \prime}->0.375^{\prime \prime}$ & 1.4 \\
\hline$\leq 0.375$ - > \#4 sieve & 1.3 \\
\hline Specific gravity & 2.502 \\
\hline Percent absorption & 2.0 \\
\hline
\end{tabular}

\begin{tabular}{|l|c|}
\hline PRODUCTION CONSTANT & 7.5 \\
\hline Estimated gravel thickness (feet) & 17,243 \\
\hline Constant - Maximum recoverable product (tons per acre) & 13,277 \\
\hline Constant - Minimum recoverable product (tons per acre) & \\
\hline CONCLUSIONS & \\
\hline Portland cement concrete - May be suitable. Will require crushing and screening and may require \\
washing. Determine susceptibility to alkali-silica reaction. May require use of low-alkali cement or \\
additives. \\
Asphalt concrete - Suitable. Will require crushing and screening. \\
Base - Suitable. Will require crushing and screening. \\
Specific gravity - May be unacceptable. \\
\hline
\end{tabular}




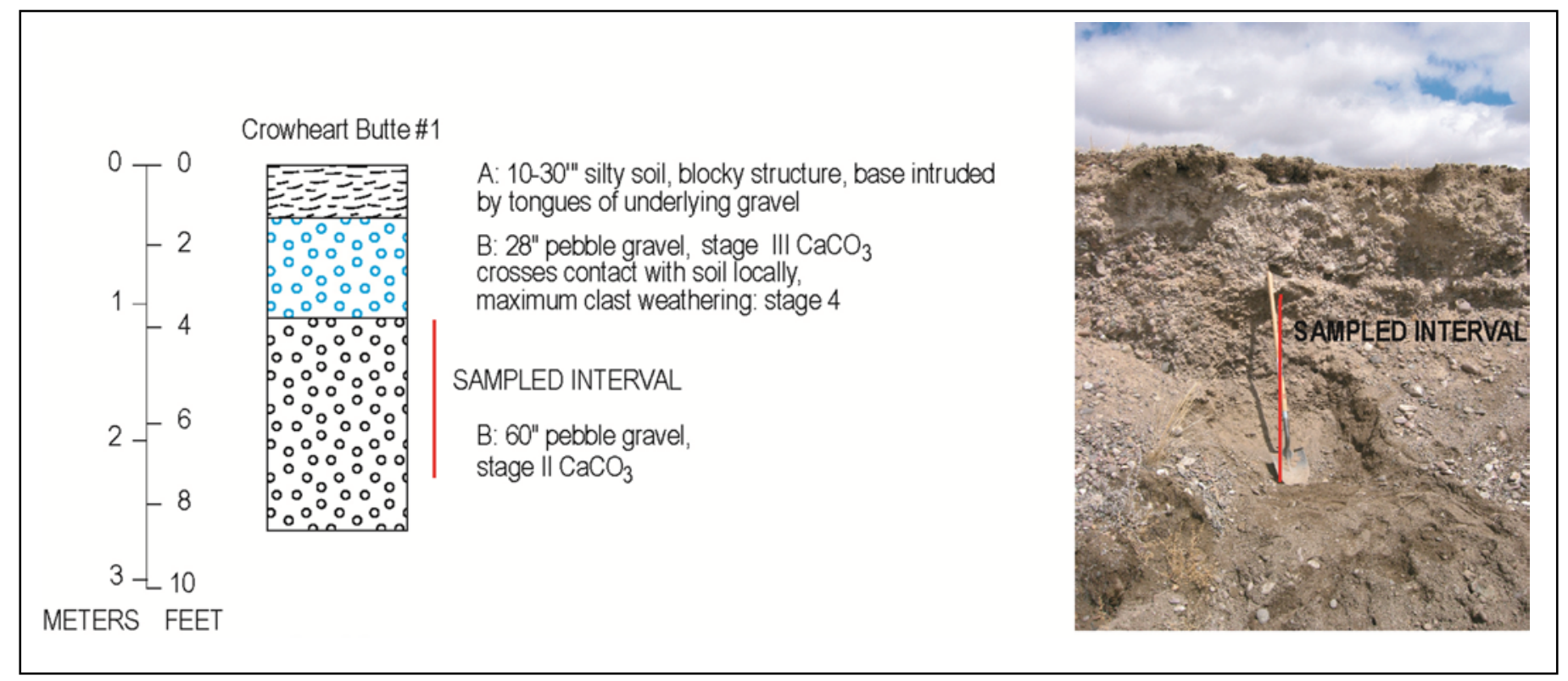




\begin{tabular}{|c|c|c|c|c|c|}
\hline \multicolumn{6}{|c|}{ SCENIC QUALITY FIELD INVENTORY AND EVALUATION CHART } \\
\hline \multicolumn{6}{|c|}{ LANDSCAPE TYPE } \\
\hline \multicolumn{6}{|c|}{ Feature-Dominated by a prominent landform, Crowheart Butte. } \\
\hline \multicolumn{6}{|c|}{ LANDSCAPE ANALYSIS FACTORS } \\
\hline \multicolumn{6}{|c|}{ Scale is vast with middle ground merging with background. } \\
\hline \multicolumn{6}{|c|}{ LANDSCAPE CHARACTER } \\
\hline & \multicolumn{2}{|c|}{ LANDFORM/WATER } & \multirow{2}{*}{\multicolumn{2}{|c|}{$\begin{array}{l}\text { VEGETATION } \\
\text { Rounded, spreading, few, } \\
\text { nondirectional. }\end{array}$}} & STRUCTURE \\
\hline FORM & \multicolumn{2}{|c|}{$\begin{array}{l}\text { Flattened, pyramidal, high, } \\
\text { jagged. }\end{array}$} & & & \\
\hline LINE & \multicolumn{2}{|c|}{ Horizontal, broken, hard. } & \multicolumn{2}{|c|}{ Weak, broken. } & Curving, straight. \\
\hline COLOR & \multicolumn{2}{|l|}{ Tan, pale orange. } & \multicolumn{2}{|c|}{ Grey/green, pale yellow. } & Tan. \\
\hline TEXTURE & \multicolumn{2}{|c|}{$\begin{array}{l}\text { Clumped, angular, coarse, and } \\
\text { medium. }\end{array}$} & \multicolumn{2}{|c|}{ Medium, rough, discontinuo } & Smooth. \\
\hline \multicolumn{6}{|c|}{ LANDSCAPE NARRATIVE } \\
\hline \multirow{3}{*}{\multicolumn{6}{|c|}{$\begin{array}{l}\text { The Crowheart Butte } \# 1 \text { site (el } 6,120 \mathrm{ft} \text { ) is located about } 3 \text { air miles from U.S. Hwy } 26 / 287 \text {. However, the site is } \\
\text { accessed approximately } 7 \text { mi, via Lenore Bridge Road, on a dirt road from the highway. The site is approximately } 54 \\
\text { mi northwest of Lander. } \\
\text { There is a vista of surrounding mountains forming a backdrop; the Wind River valley is visible in the middle ground. } \\
\text { Low cloud cover may have reduced back ground visibility. Flat, rolling terrain characterizes the foreground. } \\
\text { Surrounding terraces are discernable. The site would be exposed from all sides in terms of possible development. It is } \\
\text { distant enough from the main road and housing along Crow Creek that there would be little impact to observers. } \\
\text { Crowheat Butte itself (el } 6,764 \mathrm{ft} \text { ) is about } 2.5 \text { mi southeast. Crowheart Butte has a historic significance, but the } \\
\text { Crowheart Butte } \# 1 \text { site is considered to be outside its viewshed. } \\
\text { The vegetation is sparse and consists mainly of sagebrush and grasses. The vegetation density and size increase in } \\
\text { the draws. The landform exhibits some contrast due to exposed sandstone and gravel. }\end{array}$}} \\
\hline & & & & & \\
\hline & & & & & \\
\hline \multicolumn{6}{|c|}{ SCENIC QUALITY RATING } \\
\hline & & \multicolumn{4}{|c|}{ SCORE } \\
\hline \multicolumn{2}{|c|}{ LANDFORM } & 5 & 3 & 1 & \\
\hline \multicolumn{2}{|c|}{ VEGETATION } & 5 & 3 & 1 & \\
\hline \multicolumn{2}{|l|}{ WATER } & 5 & 3 & 0 & \\
\hline \multicolumn{2}{|l|}{ COLOR } & 5 & 3 & 1 & \\
\hline \multicolumn{2}{|c|}{ ADJACENT SCENERY } & 5 & 3 & 0 & \\
\hline \multicolumn{2}{|c|}{ SCARCITY } & 5 & 3 & 1 & \\
\hline \multicolumn{2}{|c|}{ CULTURAL MODIFICATIONS } & 2 & 0 & -4 & \\
\hline \multicolumn{2}{|c|}{ TOTAL SCORE } & \multicolumn{4}{|c|}{$=12$} \\
\hline \multicolumn{2}{|c|}{$\begin{array}{l}\text { SCENIC QUALITY } \\
\text { CLASSIFICATION }\end{array}$} & \multicolumn{4}{|l|}{ B } \\
\hline
\end{tabular}



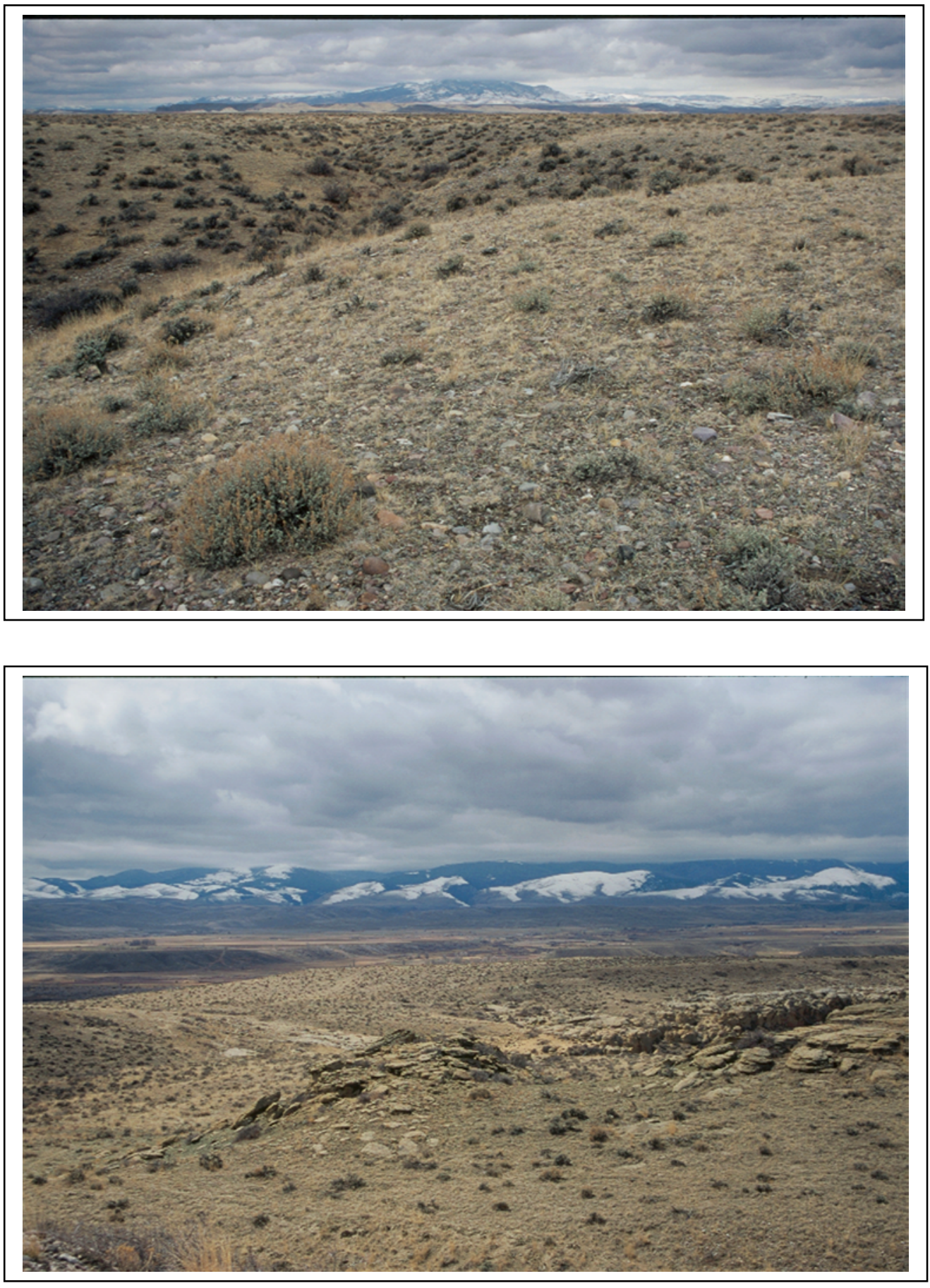

Upper, View north from terrace tread, from Crowheart Butte \#1 site. Lower, The Wind River Formation is exposed in this view west. The Wind River Mountains are in the background. 
CROWHEART BUTTE \#1: Sheet 6 of 6
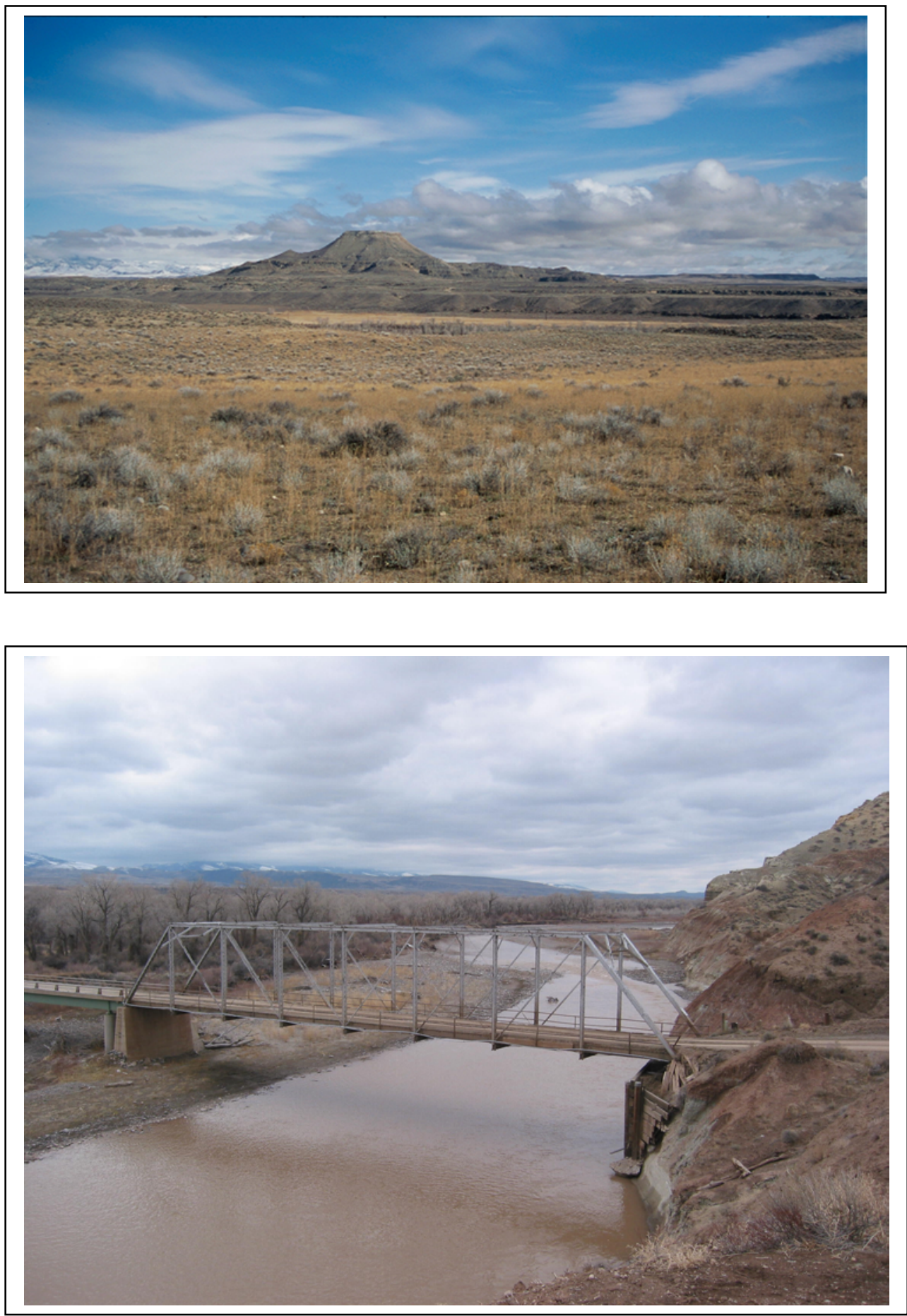

Upper, Crowheart Butte, a monolithic table-top mesa, is near the Wind River and is a dominant feature of this landscape. Lower, Vehicular traffic crosses the Wind River via a simple truss bridge and continues on Lenore Bridge Road to the Crowheart Butte \#1 site. Note the condition of the bridge abutment on the right side of the river. 
Site Name: East Boysen Causeway

Location: NE1/4, SE $1 / 4$, S21, T3N, R6E, Wind River Meridian

USGS Topographic Sheet: Hidden Valley

Date: 18 April 2005: 23 April 2005

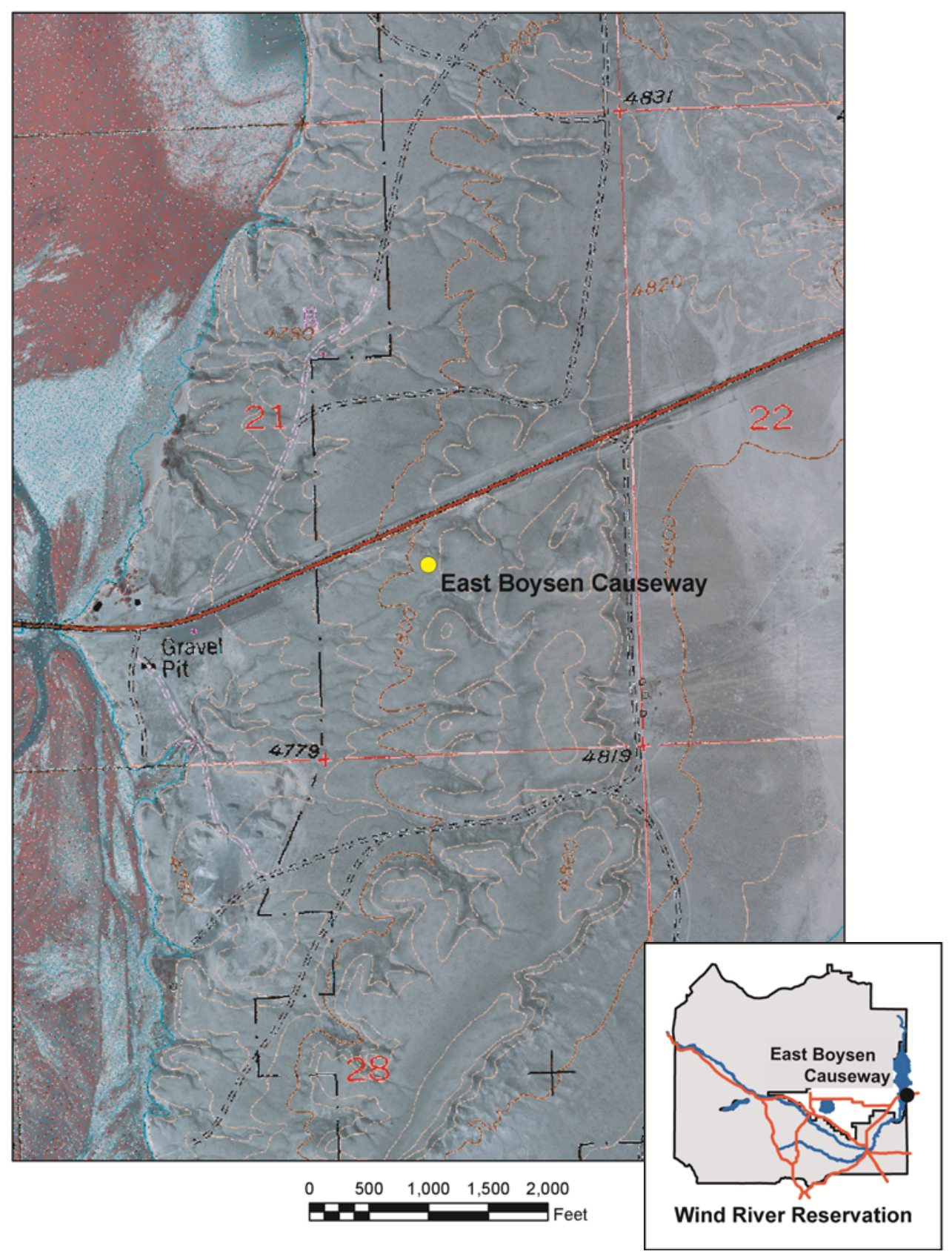




\begin{tabular}{|c|c|c|c|c|c|}
\hline \multicolumn{6}{|c|}{ GEOLOGIC OBSERVATIONS } \\
\hline Investigator & USGS & \multicolumn{3}{|c|}{ HMK Engineering*1 } & \multirow{2}{*}{$\begin{array}{c}\text { General site } \\
\text { characteristics }\end{array}$} \\
\hline Sample number & $\# 1$ & $\begin{array}{c}\text { Causeway } \\
\# 2,3\end{array}$ & $\begin{array}{l}\text { Causeway } \\
\quad \# 5,6\end{array}$ & $\begin{array}{l}\text { Causeway } \\
\text { Average } 11 \\
\text { test pits }\end{array}$ & \\
\hline Location & $\begin{array}{l}43^{\circ} 13^{\prime} 15.4^{\prime \prime} \\
108^{\circ} 09^{\prime} 56.6^{\prime \prime}\end{array}$ & - & - & - & - \\
\hline Terrace level Qt & 2 & - & - & - & 2 \\
\hline Gravel thickness (feet) & 6.5 & - & - & - & 6.5 \\
\hline $\begin{array}{l}\text { Overburden thickness } \\
\text { (feet) }\end{array}$ & 1 & - & - & - & 1 \\
\hline Water table & None observed & - & - & - & - \\
\hline $\begin{array}{l}\text { Caliche thickness } \\
\text { (feet) }\end{array}$ & 2 & - & - & - & 2 \\
\hline $\begin{array}{l}\text { Maximum carbonate } \\
\text { stage }\end{array}$ & II & - & - & - & II \\
\hline $\begin{array}{l}\text { Maximum clast } \\
\text { weathering }\end{array}$ & - & - & - & - & - \\
\hline \multicolumn{6}{|l|}{ Lithologies (pct) } \\
\hline Granite-gneiss & 36 & - & - & - & 36 \\
\hline $\begin{array}{l}\text { Mafic plutonic- } \\
\text { metamorphic }\end{array}$ & 7 & - & - & - & 7 \\
\hline Quartzite & 15 & - & - & - & 15 \\
\hline Vein quartz & Trace & - & - & - & Trace \\
\hline Sandstone & 5 & - & - & - & 5 \\
\hline Limestone & Trace & - & - & - & Trace \\
\hline Chert & - & - & - & - & - \\
\hline Volcanics & 36 & - & - & - & 36 \\
\hline Total & $99 * 2$ & - & - & - & $99 * 2$ \\
\hline
\end{tabular}

*1 Eastern Shoshone Oil \& Gas Commission, 2005

*2 Total does not equal 100 due to rounding. 


\begin{tabular}{|c|c|c|c|c|c|}
\hline \multicolumn{6}{|c|}{ ENGINEERING TESTS } \\
\hline Investigator & USGS & \multicolumn{3}{|c|}{ HMK Engineering ${ }^{* 1}$} & \multirow[b]{2}{*}{$\begin{array}{l}\text { General site } \\
\text { characteristics }\end{array}$} \\
\hline Sample number & $\# 1$ & $\begin{array}{c}\text { Causeway } \\
\quad \# 1,3\end{array}$ & $\begin{array}{c}\text { Causeway } \\
\quad \# 6\end{array}$ & $\begin{array}{c}\text { Causeway } \\
\text { Average } 11 \\
\text { test pits }\end{array}$ & \\
\hline \multicolumn{6}{|l|}{ Grain Size Analysis } \\
\hline $\begin{array}{l}\text { Maximum clast size } \\
\text { (inches) }\end{array}$ & $>3$ & - & - & - & $>3$ \\
\hline \multicolumn{6}{|c|}{ Size distribution (percent) } \\
\hline Cobbles & - & 11.5 & 18.0 & 11 & 11 \\
\hline Coarse Gravel & - & 36.5 & 28.0 & 29 & 30 \\
\hline Fine Gravel & - & 7.0 & 16.0 & 16 & 15 \\
\hline Sand & - & 37.0 & 33 & 37.2 & 37.2 \\
\hline Fines & - & 8.0 & 4.9 & 6.8 & 6.9 \\
\hline Total & - & 100 & $99.9^{\star}$ & 100 & $100.1^{* 2}$ \\
\hline LA Value & - & 27 & 26 & & 27 \\
\hline \multicolumn{6}{|l|}{ Soundness } \\
\hline$\leq 1.5^{\prime \prime}->0.75^{\prime \prime}$ & - & 3.3 & 1.4 & - & 2.35 \\
\hline$\leq 0.75^{\prime \prime}->0.375^{\prime \prime}$ & - & 1.9 & 2.0 & - & 1.95 \\
\hline$\leq 0.375$ - > \#4 sieve & - & - & - & - & - \\
\hline Specific gravity & - & 2.596 & 2.617 & - & 2.607 \\
\hline Percent absorption & - & 1.24 & 1.12 & - & 1.18 \\
\hline
\end{tabular}

*1 Eastern Shoshone Oil \& Gas Commission, 2005

*2 Total does not equal 100 due to rounding.

\begin{tabular}{|l|c|}
\hline PRODUCTION CONSTANT & 6.5 \\
\hline Estimated gravel thickness (feet) & 14,944 \\
\hline Constant - Maximum recoverable product & 10,668 \\
\hline Constant - Minimum recoverable product \\
\hline CONCLUSIONS \\
\hline $\begin{array}{l}\text { Portland cement concrete - May be suitable. Will require crushing and screening and may require } \\
\text { washing. Determine susceptibility to alkali-silica reaction. May require use of low-alkali cement or } \\
\text { additives. } \\
\text { Asphalt concrete - Suitable. Will require crushing and screening. } \\
\text { Base - Suitable. Will require crushing and screening. }\end{array}$ \\
\hline
\end{tabular}


E BOYSEN CAUSEWAY: Sheet 4 of 7

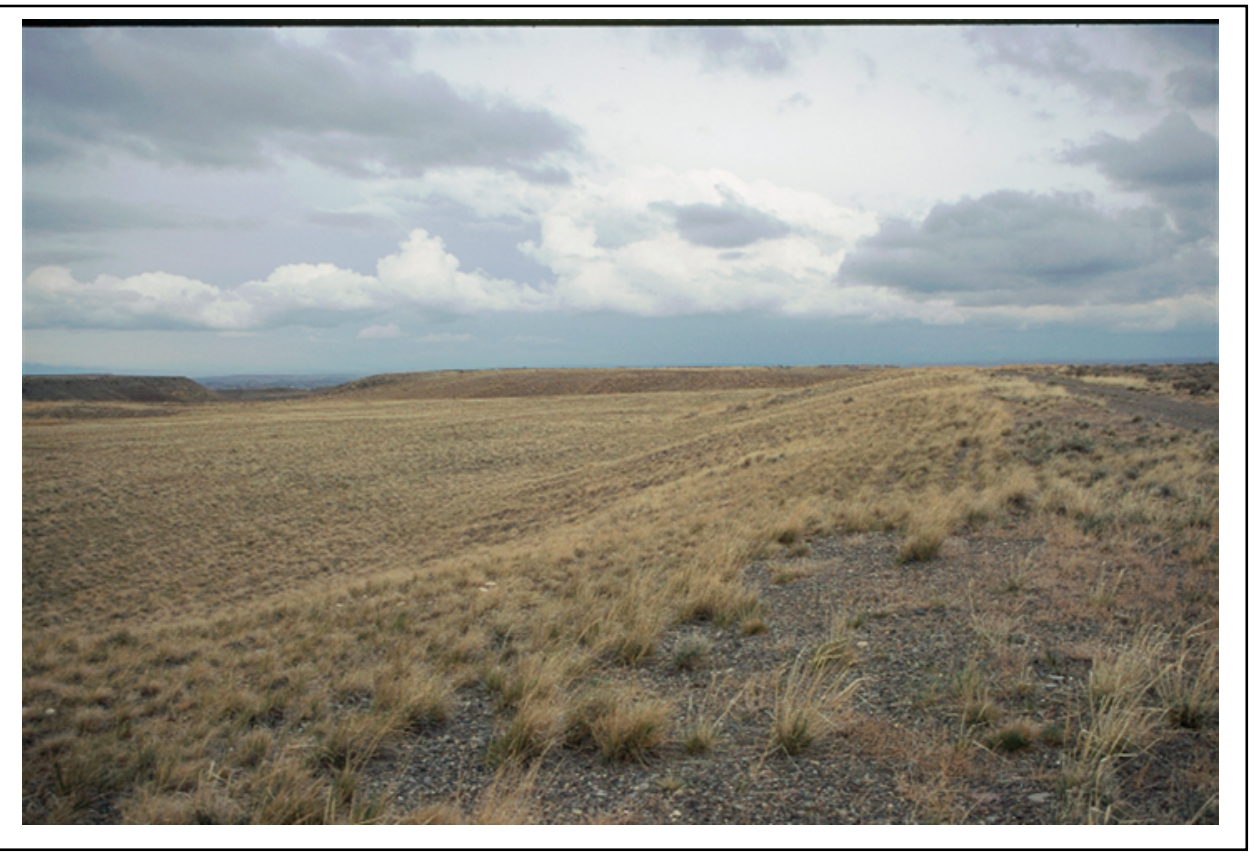

There are no natural or man-made exposures at this site. No geologic columns were prepared. 
This page intentionally left blank. 
E BOYSEN CAUSEWAY: Sheet 6 of 7

\begin{tabular}{|c|c|c|c|c|c|}
\hline \multicolumn{6}{|c|}{ SCENIC QUALITY FIELD INVENTORY AND EVALUATION CHART } \\
\hline \multirow{2}{*}{\multicolumn{6}{|c|}{ LANDSCAPE TYPE }} \\
\hline \multirow{2}{*}{\multicolumn{6}{|c|}{$\begin{array}{l}\text { Panoramic } \\
\text { LANDSCAPE ANALYSIS FACTORS }\end{array}$}} \\
\hline & & & & & \\
\hline \multicolumn{6}{|c|}{ The landscape has little contrast. } \\
\hline \multicolumn{6}{|c|}{ LANDSCAPE CHARACTER } \\
\hline & \multicolumn{2}{|c|}{ LANDFORM/WATER } & \multicolumn{2}{|c|}{ VEGETATION } & STRUCTURE \\
\hline FORM & \multicolumn{2}{|l|}{ Flat, convex. } & \multicolumn{2}{|c|}{ Grasses and sparse sage. } & $\begin{array}{l}\text { Square sheds, highway, } \\
\text { barbed wire fence, and dirt } \\
\text { road. }\end{array}$ \\
\hline LINE & \multicolumn{2}{|l|}{ Smooth. } & \multicolumn{2}{|l|}{ Points. } & Parallel to terrace. \\
\hline COLOR & \multicolumn{2}{|c|}{ Pale green, blue, grey, pale pink. } & \multicolumn{2}{|c|}{ Grey-green, tan. } & Dark grey, light brown. \\
\hline TEXTURE & \multicolumn{2}{|l|}{ Medium. } & \multicolumn{2}{|l|}{ Matte. } & Rough, even, fine. \\
\hline \multicolumn{6}{|c|}{ LANDSCAPE NARRATIVE } \\
\hline \multicolumn{6}{|c|}{$\begin{array}{l}\text { The East Boysen Causeway site (el 4,830 ft) is easily accessible from U.S. Hwy 26. It is approximately } 20 \text { miles east } \\
\text { of Riverton and } 4 \text { miles west of Shoshoni. There are distant views of Boysen Reservoir, the town of Shoshoni, and the } \\
\text { Owl Creek Mountains that normally would not be considered under Adjacent Scenery. However, due to the low } \\
\text { overall rating, a score of } 3 \text { was given due to the dominant landform, besides the foreground terraces, Water Tank Hill } \\
\text { (in the middle ground). The Chicago and North Western Railroad is approximately } 1 \text { mi to the southeast. }\end{array}$} \\
\hline \multicolumn{6}{|c|}{$\begin{array}{l}\text { The E. Boysen Causeway site includes an example of reclamation by the Wyoming Department of Transportation. A } \\
\text { former sand and gravel pit was apparently reclaimed so that a terrace edge was utilized for camouflage, acted as a } \\
\text { buffer, and blended with small terrace toes to conform to surrounding topography. }\end{array}$} \\
\hline \multicolumn{6}{|c|}{$\begin{array}{l}\text { Antelope were observed in the foreground. The texture is mainly fine both for landform and vegetation. The landscape } \\
\text { is monotone and tiered. }\end{array}$} \\
\hline \multicolumn{6}{|c|}{$\begin{array}{l}\text { Cultural modifications include wood sheds, poles, and storage piles of sand and gravel (poorly positioned). Some } \\
\text { vegetation is grazed out. The site is in view from the highway heading south for } 0.5 \mathrm{mi} \text {. }\end{array}$} \\
\hline \multicolumn{6}{|c|}{ SCENIC QUALITY RATING } \\
\hline & & \multicolumn{4}{|c|}{ SCORE } \\
\hline \multicolumn{2}{|c|}{ LANDFORM } & 5 & 3 & 1 & \\
\hline \multicolumn{2}{|c|}{ VEGETATION } & 5 & 3 & 1 & \\
\hline \multicolumn{2}{|l|}{ WATER } & 5 & 3 & 0 & \\
\hline \multicolumn{2}{|l|}{ COLOR } & 5 & 3 & 1 & \\
\hline \multicolumn{2}{|c|}{ ADJACENT SCENERY } & 5 & 3 & 0 & \\
\hline \multicolumn{2}{|l|}{ SCARCITY } & 5 & 3 & 1 & \\
\hline \multicolumn{2}{|c|}{ CULTURAL MODIFICATIONS } & 2 & 0 & -4 & \\
\hline \multicolumn{2}{|c|}{ TOTAL SCORE } & \multicolumn{4}{|c|}{$=6$} \\
\hline \multicolumn{2}{|c|}{$\begin{array}{l}\text { SCENIC QUALITY } \\
\text { CLASSIFICATION }\end{array}$} & \multicolumn{4}{|l|}{$\mathbf{C}$} \\
\hline
\end{tabular}




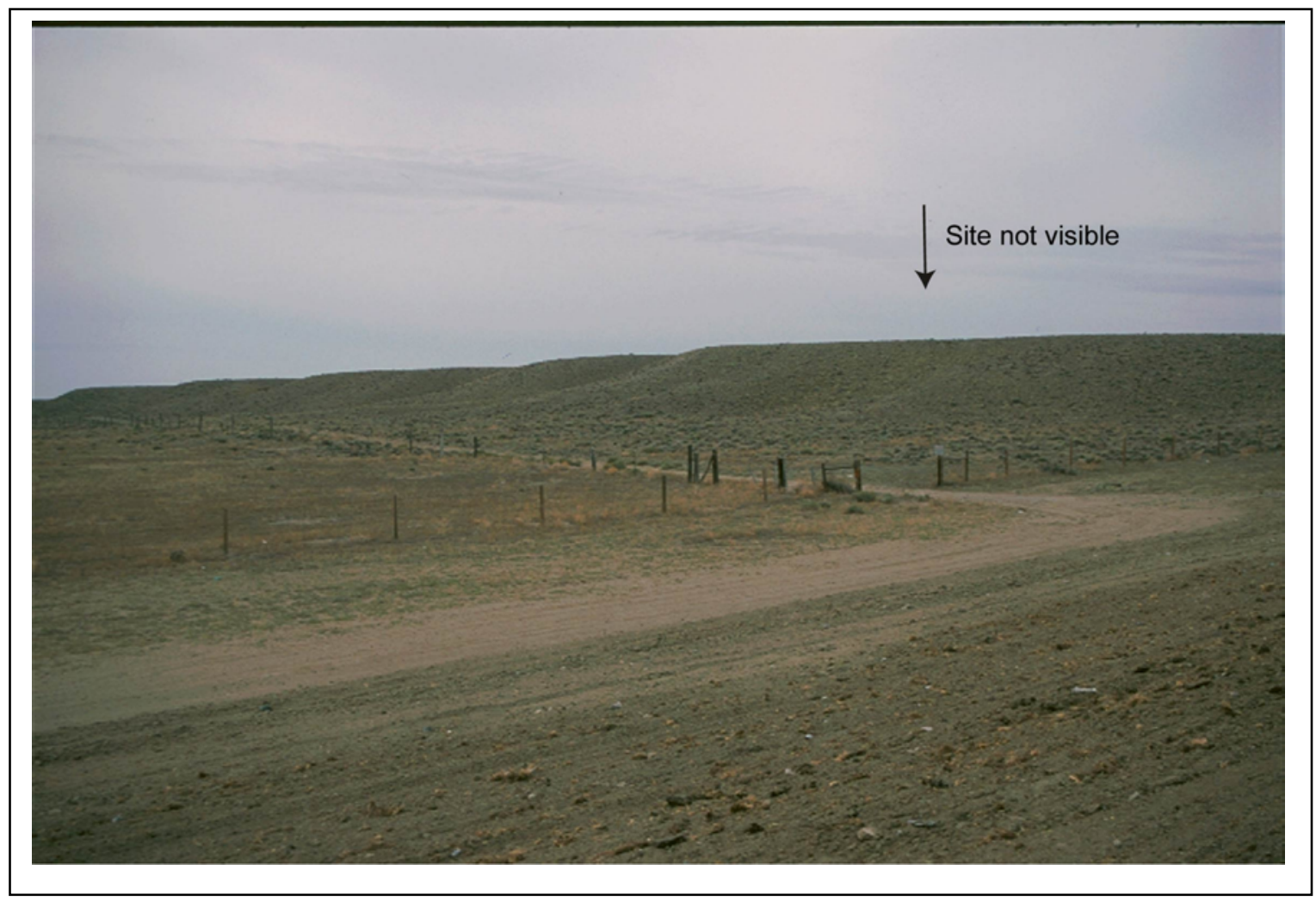

This view is from U.S. Hwy 26, looking south, towards the terraces and the E. Boysen Causeway site. The terrace slopes are plainly visible and block viewing of background objects. The site is not visible from the road despite being located on the terrace top. The vegetation and landform lack visual variety and therefore typically are considered less visually appealing. 
This page intentionally left blank. 


\section{Site Name: Johnstown}

Location: NE 1/4, NW 1/4, S26, T2N, R1E, Wind River Meridian USGS Topographic Sheet: Pavillion

Date: 23 April 2005

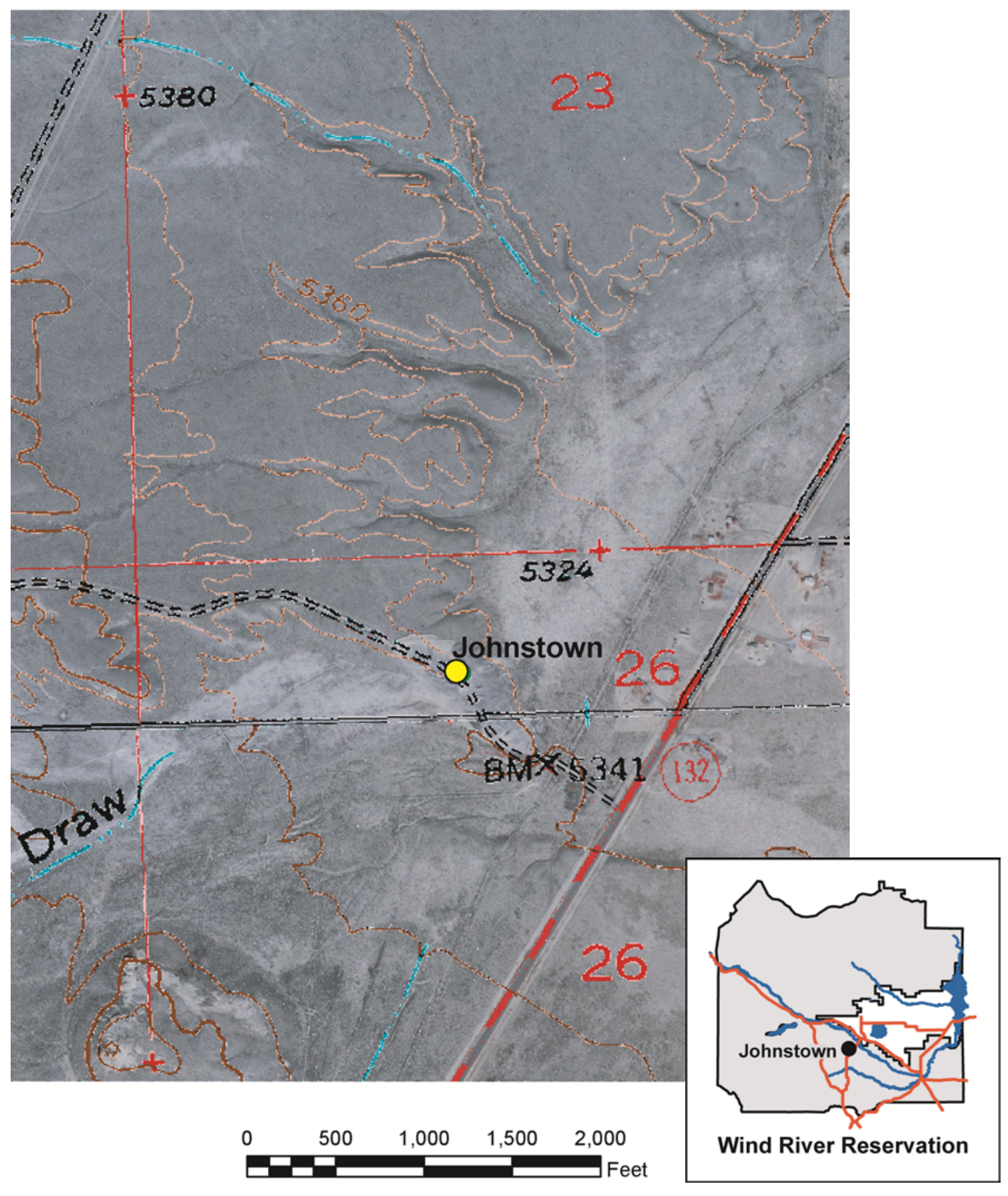




\begin{tabular}{|c|c|}
\hline \multicolumn{2}{|c|}{ GEOLOGIC DESCRIPTION } \\
\hline Sample number & $\# 1$ \\
\hline Location & $\begin{array}{c}43^{\circ} 07^{\prime} 32.2^{\prime \prime} \\
108^{\circ} 43^{\prime} 42.2^{\prime \prime}\end{array}$ \\
\hline Terrace level Qt & 5 \\
\hline Gravel thickness (feet) & 17 \\
\hline $\begin{array}{l}\text { Overburden thickness } \\
\text { (feet) }\end{array}$ & 1 \\
\hline Water table & None observed \\
\hline $\begin{array}{l}\text { Caliche thickness } \\
\text { (feet) }\end{array}$ & 2 \\
\hline $\begin{array}{l}\text { Maximum carbonate } \\
\text { stage: }\end{array}$ & $\|$ \\
\hline $\begin{array}{l}\text { Maximum clast } \\
\text { weathering }\end{array}$ & 3 \\
\hline \multicolumn{2}{|l|}{ Lithologies (pct) } \\
\hline Granite-gneiss & 42 \\
\hline $\begin{array}{l}\text { Mafic plutonic- } \\
\text { metamorphic }\end{array}$ & 4 \\
\hline Quartzite & 16 \\
\hline Vein quartz & - \\
\hline Sandstone & 13 \\
\hline Limestone & Trace \\
\hline Chert & Trace \\
\hline Volcanics & 25 \\
\hline Total & 100 \\
\hline
\end{tabular}

\begin{tabular}{|c|c|}
\hline \multicolumn{2}{|c|}{ ENGINEERING TESTS } \\
\hline Sample number & $\# 1$ \\
\hline $\begin{array}{l}\text { Maximum clast size } \\
\text { (inches) }\end{array}$ & $>3$ \\
\hline \multicolumn{2}{|c|}{ Size distribution (percent) } \\
\hline Cobbles & 35 \\
\hline Coarse Gravel & 28 \\
\hline Fine Gravel & 15 \\
\hline Sand & 20.8 \\
\hline Fines & 1.2 \\
\hline Total & 100 \\
\hline LA Value & 22.9 \\
\hline \multicolumn{2}{|l|}{ Soundness (pct) } \\
\hline$\leq 1.5^{\prime \prime}->0.75^{\prime \prime}$ & 0.2 \\
\hline$\leq 0.75^{\prime \prime}->0.375^{\prime \prime}$ & 0.2 \\
\hline$\leq 0.375$ - >\#4 sieve & 0.1 \\
\hline Specific gravity & 2.592 \\
\hline Percent absorption & 1.3 \\
\hline
\end{tabular}

\begin{tabular}{|l|c|}
\hline PRODUCTION CONSTANT & 17 \\
\hline Estimated gravel thickness (feet) & 39,083 \\
\hline Constant - Maximum recoverable product (tons per acre) & 20,377 \\
\hline Constant - Minimum recoverable product (tons per acre) & \\
\hline CONCLUSIONS & \\
\hline Portland cement concrete - May be suitable. Will require crushing and screening and may require \\
washing. Determine susceptibility to alkali-silica reaction. May require use of low-alkali cement or \\
additives. \\
Asphalt concrete - Suitable. Will require crushing and screening. \\
Base - Suitable. Will require crushing and screening. \\
Difficult mining - Large amount of cobbles may require removal with a grizzly screen. \\
\hline
\end{tabular}


JOHNSTOWN: Sheet 3 of 6

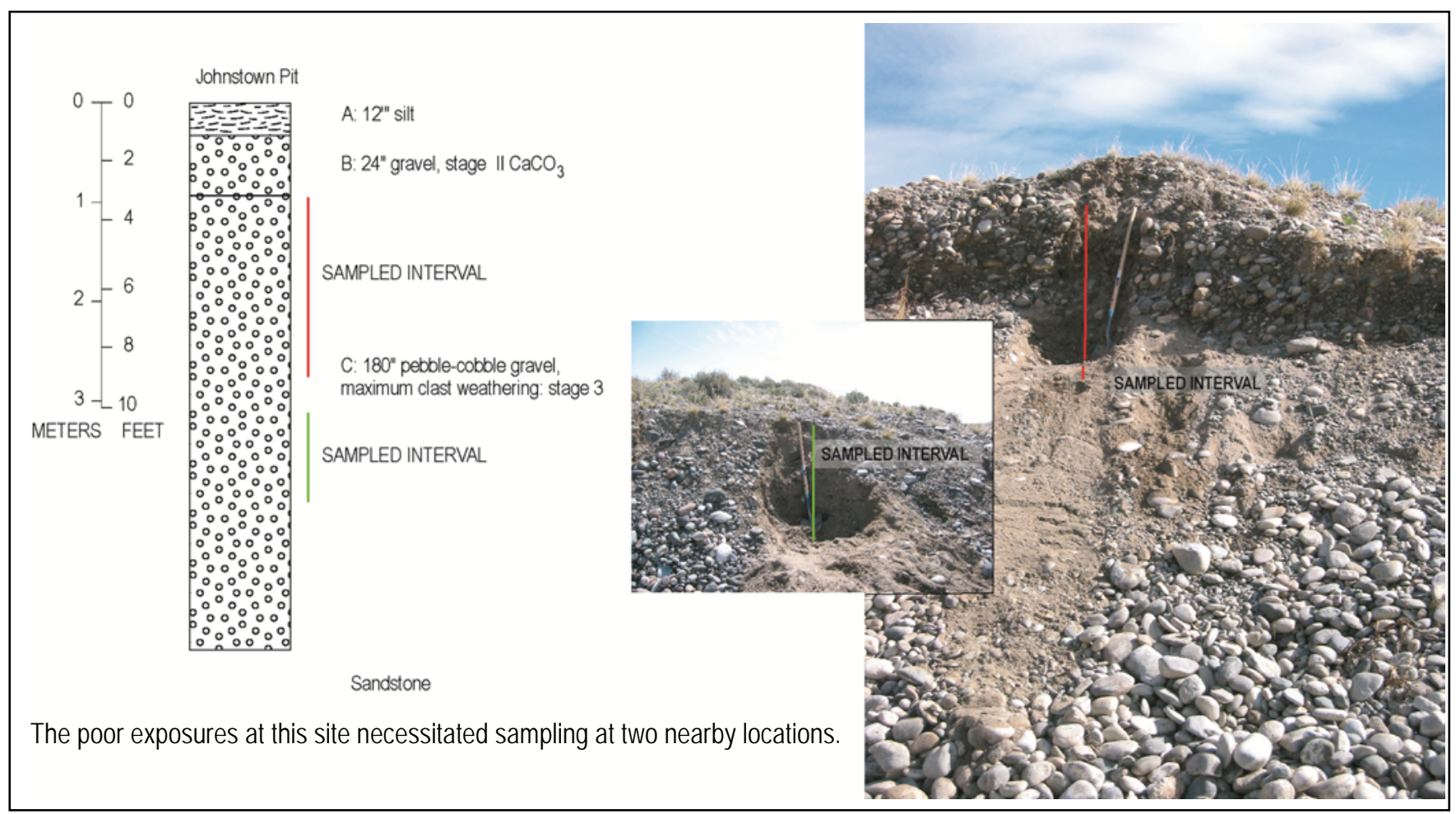




\begin{tabular}{|c|c|c|c|c|c|}
\hline \multicolumn{6}{|c|}{ SCENIC QUALITY FIELD INVENTORY AND EVALUATION CHART } \\
\hline \multicolumn{6}{|c|}{ LANDSCAPE TYPE } \\
\hline \multicolumn{6}{|c|}{ Panoramic } \\
\hline \multicolumn{6}{|c|}{ LANDSCAPE ANALYSIS FACTORS } \\
\hline \multicolumn{6}{|c|}{ The landscape offers refuge in the built form. } \\
\hline \multicolumn{6}{|c|}{ LANDSCAPE CHARACTER } \\
\hline & \multirow{2}{*}{\multicolumn{2}{|c|}{$\begin{array}{l}\text { LANDFORM/WATER } \\
\text { Co-dominance, flat, definite, } \\
\text { large, few. }\end{array}$}} & \multicolumn{2}{|c|}{ VEGETATION } & STRUCTURE \\
\hline FORM & & & \multicolumn{2}{|c|}{ Low, simple, rounded. } & Rectangular, low, regular. \\
\hline LINE & \multicolumn{2}{|l|}{ Indistinct, horizontal. } & \multicolumn{2}{|c|}{$\begin{array}{l}\text { Curvilinear edge, contrasting } \\
\text { horizontal (riparian) }\end{array}$} & Straight, vertical, regular. \\
\hline COLOR & \multicolumn{2}{|l|}{ Yellow, light brown. } & \multicolumn{2}{|c|}{ Light tan, grey-green. } & Glaring, tan, green, white. \\
\hline TEXTURE & \multicolumn{2}{|l|}{ Smooth } & \multicolumn{2}{|c|}{ Stippled, smooth } & Matte \\
\hline \multicolumn{6}{|c|}{ LANDSCAPE NARRATIVE } \\
\hline \multirow{3}{*}{\multicolumn{6}{|c|}{$\begin{array}{l}\text { The Johnstown site (el } 5,360 \mathrm{ft} \text { ) is on a dirt road, just } 0.5 \text { mile from the Ethete Cutoff, Hwy } 132 \text {. U.S. Hwy } 26 \text { is about } 3 \\
\text { mi north and Riverton is approximately } 22 \text { mi away. The Johnstown Valley and Wind River are east and discernable } \\
\text { only by the flat expanse and string of cottonwoods. Edmo Buttes give the only visual landform relief; blending with the } \\
\text { valley and appearing to stretch along in the back ground. A draw north of the site is hidden from view. } \\
\text { Vegetation is characterized by medium (sage) and fine (grazed) texture. It appears monotonous over a majority of the } \\
\text { space. } \\
\text { Nine homes are located } 0.5 \mathrm{mi} \text {, adjacent to Hwy } 32 \text {, from the site. The medium-duty road has a lot of local traffic. The } \\
\text { site is visible (mainly due to the sand piles) along Hwy } 132 \text { for } 1.7 \text { mi after reaching the lower terrace heading north. } \\
\text { The site is visible heading south for } 0.5 \mathrm{mi} \text {. The sand piles are noticeable on the flat landscape. }\end{array}$}} \\
\hline & & & & & \\
\hline & & & & & \\
\hline \\
\hline \multicolumn{6}{|c|}{ SCENIC QUALITY RATING } \\
\hline \multicolumn{2}{|c|}{ LANDFORM } & 5 & 3 & 1 & \\
\hline \multicolumn{2}{|c|}{ VEGETATION } & 5 & 3 & 1 & \\
\hline \multicolumn{2}{|l|}{ WATER } & 5 & 3 & 0 & \\
\hline \multicolumn{2}{|l|}{ COLOR } & 5 & 3 & 1 & \\
\hline \multicolumn{2}{|c|}{ ADJACENT SCENERY } & 5 & 3 & 0 & \\
\hline \multicolumn{2}{|c|}{ SCARCITY } & 5 & 3 & 1 & \\
\hline \multicolumn{2}{|c|}{ CULTURAL MODIFICATIONS } & 2 & 0 & -4 & \\
\hline \multicolumn{2}{|c|}{ TOTAL SCORE } & \multicolumn{4}{|c|}{$=8$} \\
\hline \multicolumn{2}{|c|}{$\begin{array}{l}\text { SCENIC QUALITY } \\
\text { CLASSIFICATION }\end{array}$} & \multicolumn{4}{|l|}{ C } \\
\hline
\end{tabular}


JOHNSTOWN: Sheet 5 of 6
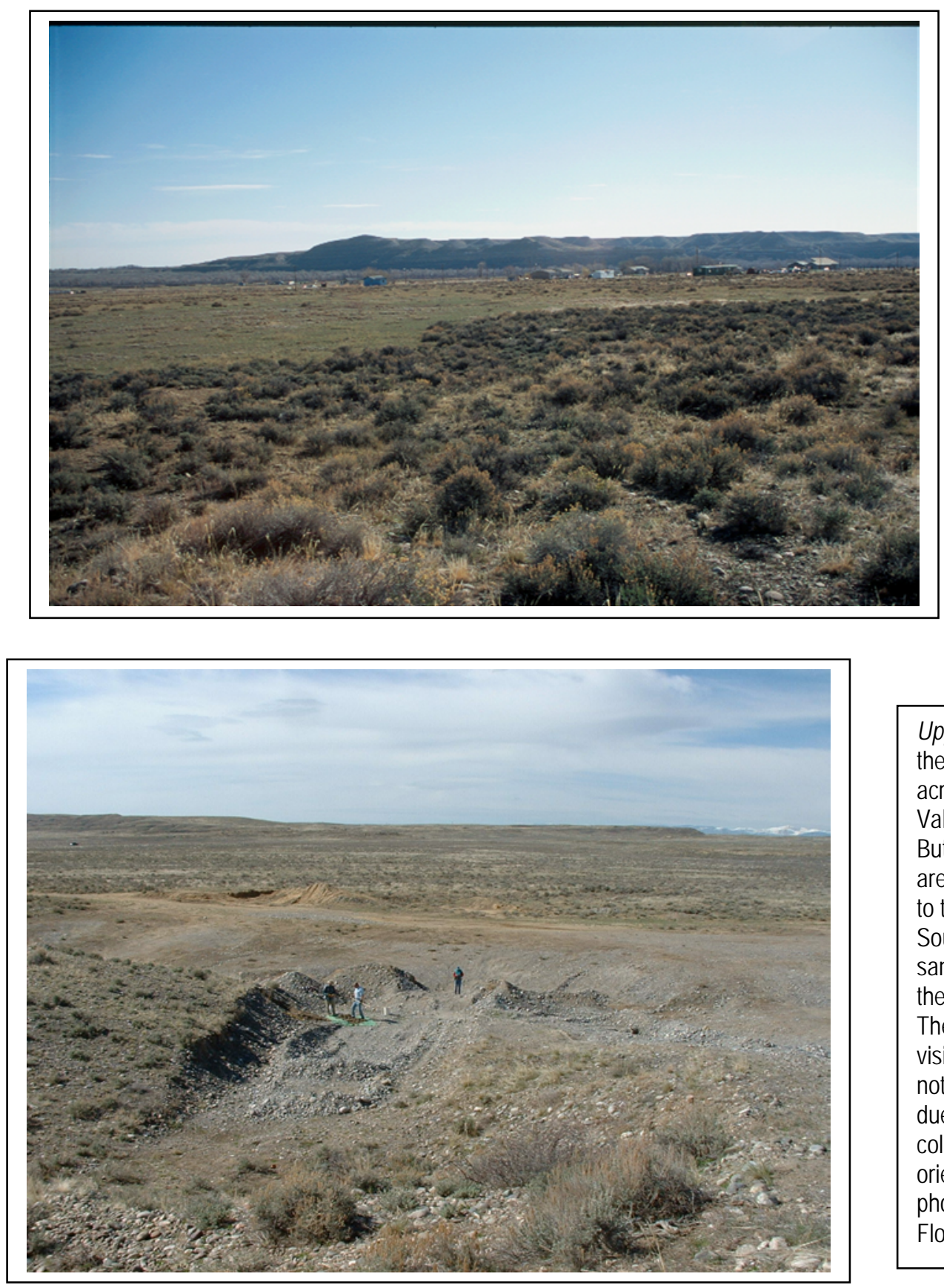

Upper, View east from the Johnstown site across Johnstown Valley and Edmo Buttes. Residences are in close proximity to the site. Left, Southern view of the sand and gravel pit on the Johnstown site. The sand piles are visible from Hwy 132, not the gravel pit itself, due to the contrast in color, profile, and orientation. Lower photograph courtesy Floyd Phillips. 

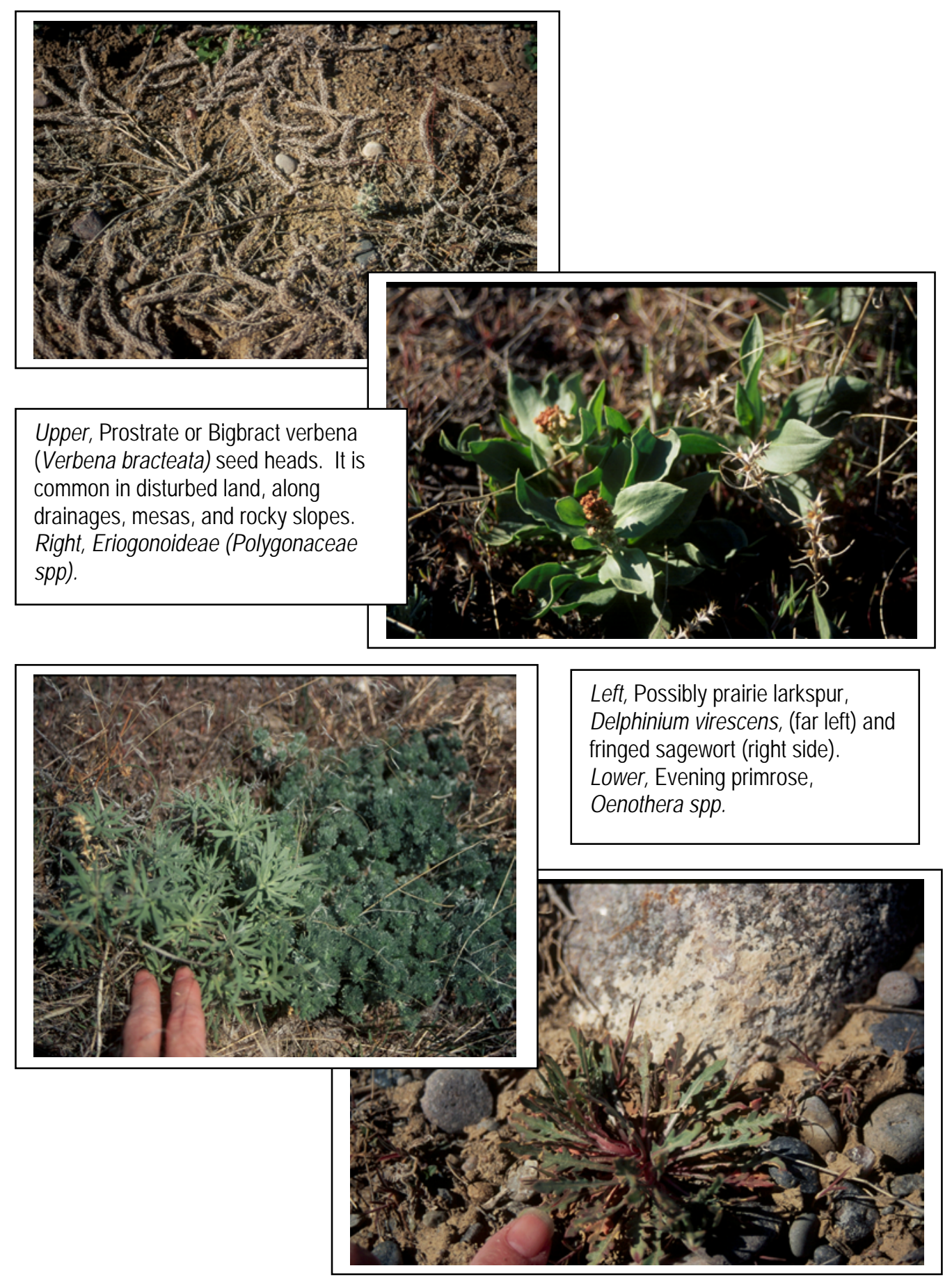


\section{Site Name: Kane Draw}

Location: NW 1/4, NE 1/4, S14, T4N, R4W, Wind River Meridian

USGS Topographic Sheet: Crowheart

Date: 21 April 2005

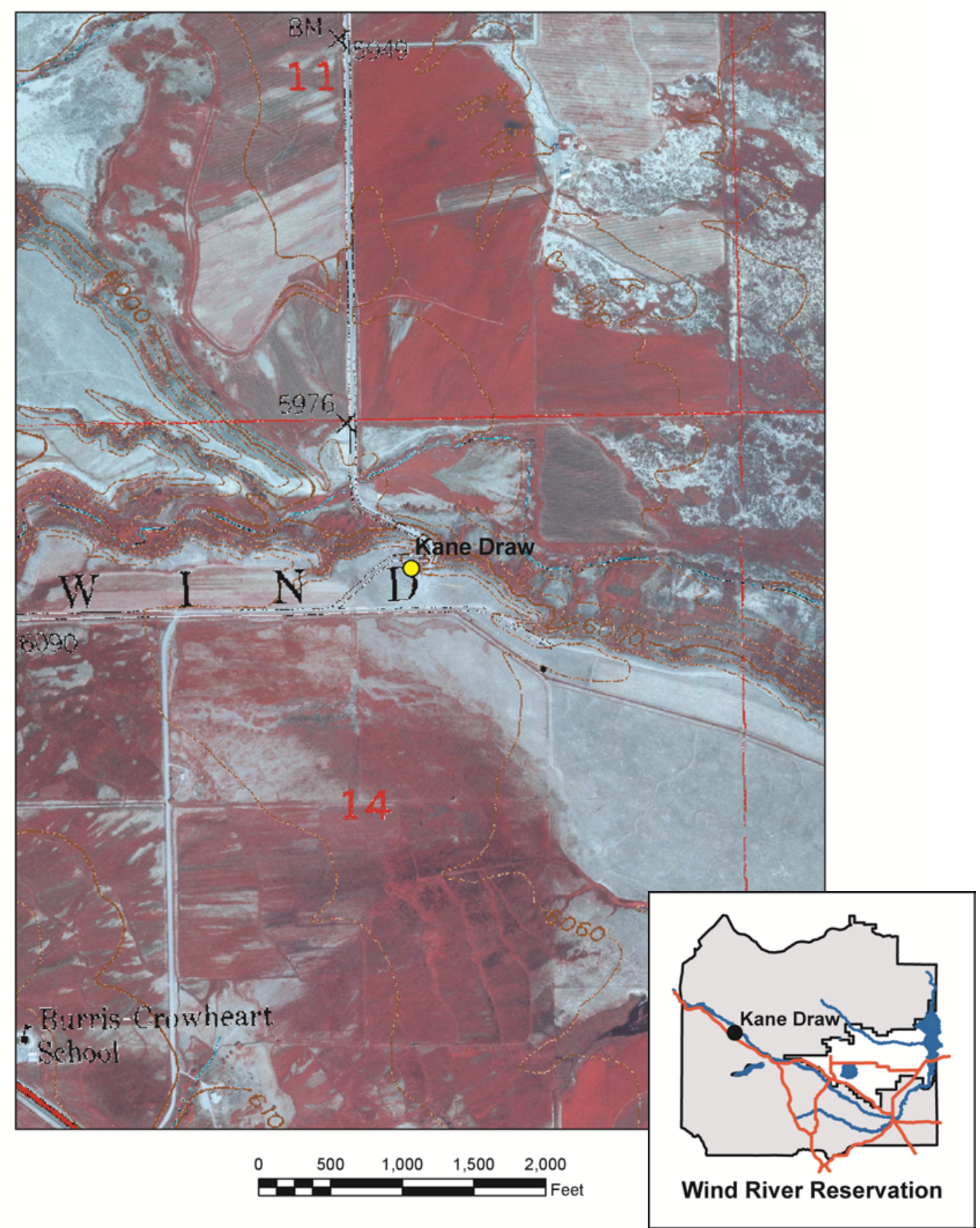




\begin{tabular}{|c|c|}
\hline \multicolumn{2}{|c|}{ GEOLOGIC DESCRIPTION } \\
\hline Sample number & $\# 1$ \\
\hline Location: & $\begin{array}{c}43^{\circ} 19^{\prime} 38.7^{\prime \prime} \\
109^{\circ} 11^{\prime} 50.3^{\prime \prime}\end{array}$ \\
\hline Terrace level Qt & 5 \\
\hline Gravel thickness (feet) & 20 \\
\hline $\begin{array}{l}\text { Overburden thickness } \\
\text { (feet) }\end{array}$ & 1 \\
\hline Water table & $\begin{array}{c}\text { Water at base of } \\
\text { gravel }\end{array}$ \\
\hline $\begin{array}{l}\text { Caliche thickness } \\
\text { (feet) }\end{array}$ & $6-8$ \\
\hline $\begin{array}{l}\text { Maximum carbonate } \\
\text { stage: }\end{array}$ & III \\
\hline $\begin{array}{l}\text { Maximum clast } \\
\text { weathering }\end{array}$ & 4 \\
\hline \multicolumn{2}{|l|}{ Lithologies (pct) } \\
\hline Granite-gneiss & 21 \\
\hline $\begin{array}{l}\text { Mafic plutonic- } \\
\text { metamorphic }\end{array}$ & 4 \\
\hline Quartzite & 16 \\
\hline Vein quartz & 2 \\
\hline Sandstone & 21 \\
\hline Limestone & - \\
\hline Chert & - \\
\hline Volcanics & 36 \\
\hline Total & 100 \\
\hline
\end{tabular}

\begin{tabular}{|c|c|}
\hline \multicolumn{2}{|c|}{ ENGINEERING TESTS } \\
\hline Sample number & $\# 1$ \\
\hline $\begin{array}{l}\text { Maximum clast size } \\
\text { (inches) }\end{array}$ & 10 \\
\hline \multicolumn{2}{|c|}{ Size distribution (percent) } \\
\hline Cobbles & 34 \\
\hline Coarse Gravel & 60 \\
\hline Fine Gravel & 21 \\
\hline Sand & 17.3 \\
\hline Fines & 1.7 \\
\hline Total & 100 \\
\hline LA Value & 26.2 \\
\hline \multicolumn{2}{|l|}{ Soundness (pct) } \\
\hline$\leq 1.5^{\prime \prime}->0.75^{\prime \prime}$ & 0.6 \\
\hline$\leq 0.75^{\prime \prime}->0.375^{\prime \prime}$ & 0.4 \\
\hline$\leq 0.375$ - >\#4 sieve & 0.4 \\
\hline Specific gravity & 2.576 \\
\hline Percent absorntion & 16 \\
\hline
\end{tabular}

\begin{tabular}{|l|c|}
\hline PRODUCTION CONSTANT & 20 \\
\hline Estimated gravel thickness (feet) & 45,980 \\
\hline Constant - Maximum recoverable product (tons per acre) & 24,341 \\
\hline Constant - Minimum recoverable product (tons per acre) & \\
\hline CONCLUSIONS & \\
\hline Portland cement concrete - May be suitable. Will require crushing and screening and may require \\
washing. Determine susceptibility to alkali-silica reaction. May require use of low-alkali cement or \\
additives. \\
Asphalt concrete - Suitable. Will require crushing and screening. \\
Base - Suitable. Will require crushing and screening. \\
Deleterious Material - Large amount of calcium carbonate (caliche) coating. Crushing will reduce \\
extent of coating. \\
Difficult mining - Large amount of cobbles may require removal with a grizzly screen. \\
\hline
\end{tabular}




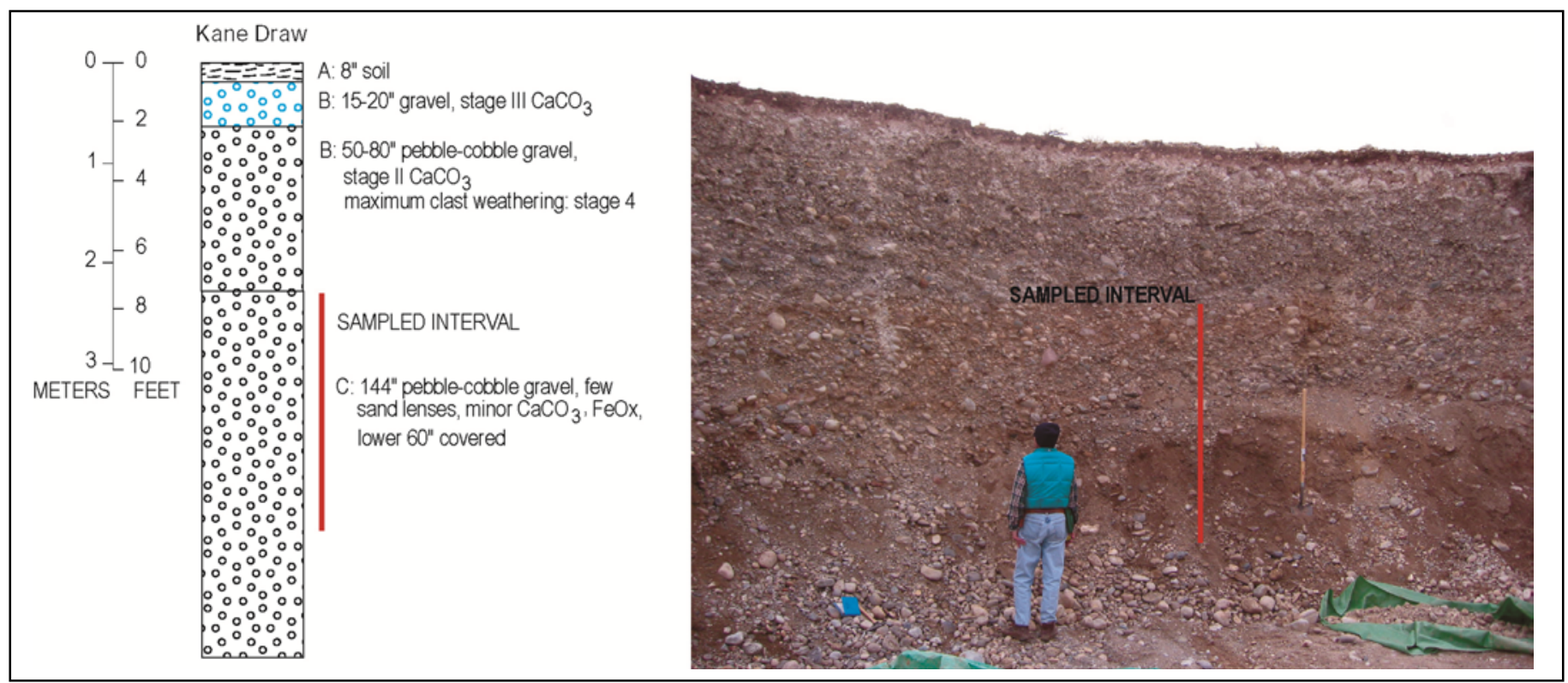




\begin{tabular}{|c|c|c|c|c|c|c|}
\hline \multirow{2}{*}{\multicolumn{7}{|c|}{$\begin{array}{l}\text { SCENIC QUALITY FIELI } \\
\text { LANDSCAPE TYPE }\end{array}$}} \\
\hline & & & & & & \\
\hline \multicolumn{7}{|c|}{ Panoramic-The middle ground objects do not substantially block viewing of back ground objects. } \\
\hline \multicolumn{7}{|c|}{ LANDSCAPE ANALYSIS FACTORS } \\
\hline \multirow{2}{*}{\multicolumn{7}{|c|}{$\begin{array}{l}\text { The terraces form a western backdrop to the Wind River Valley creating a comfortable human scale. Views in other } \\
\text { directions appear vast and exposed. } \\
\text { LANDSCAPE CHARACTER }\end{array}$}} \\
\hline & & & & & & \\
\hline & \multicolumn{2}{|c|}{ LANDFORM/WATER } & \multicolumn{3}{|c|}{ VEGETATION } & STRUCTURE \\
\hline FORM & \multicolumn{2}{|c|}{$\begin{array}{l}\text { Middle ground takes on } \\
\text { importance, fairly flat. } \\
\text { Convergence, diverse, triangular. }\end{array}$} & \multicolumn{3}{|c|}{ Fastigiate, rounded, spreading. } & $\begin{array}{l}\text { Rectangular, wide, } \\
\text { simple. }\end{array}$ \\
\hline LINE & \multicolumn{2}{|l|}{ Complex, broken. } & \multicolumn{3}{|c|}{$\begin{array}{l}\text { Strong horizontal in distance (riparian). } \\
\text { Horizontal line along terraces. }\end{array}$} & Angular, linear (road). \\
\hline COLOR & \multicolumn{2}{|c|}{ Brown, grey, tan, pink. } & \multicolumn{3}{|l|}{ Grey, gold. } & Tan, white, muted. \\
\hline TEXTURE & \multicolumn{2}{|c|}{$\begin{array}{l}\text { Medium foreground, fine middle } \\
\text { and back ground. }\end{array}$} & \multicolumn{3}{|c|}{$\begin{array}{l}\text { Fine and medium foreground, fine } \\
\text { middle and back ground. Subtle. }\end{array}$} & Smooth. \\
\hline \multicolumn{7}{|c|}{ LANDSCAPE NARRATIVE } \\
\hline \multicolumn{7}{|c|}{$\begin{array}{l}\text { The Kane Draw site (el 6,040 ft) is approximately } 1 \text { mile north of U.S. Hwy } 26 / 287 \text { on Urbigket Road. It is located } \\
\text { above a natural drainage, Kane Draw, which is visible in the foreground. Urbigket Road continues nearly due north for } \\
2 \text { mi providing linear views of the site. The Wind River flood plain is in the middle ground. The widely spaced terraces } \\
\text { create a slow rhythm. Distant views include terraces and mountains (OwI Creek and Wind River). Low cloud cover } \\
\text { may have interfered with the impact of adjacent scenery. Crowheart Butte is barely visible to the east (elevation 6,764 } \\
\text { ft). }\end{array}$} \\
\hline \multicolumn{7}{|c|}{$\begin{array}{l}\text { The texture of vegetation varies from fine to medium. Sagebrush and rubber rabbitbrush cover the north facing slope } \\
\text { of the terrace site, along with isolated groups of willows and immature cottonwoods in drainage areas }\end{array}$} \\
\hline \multicolumn{7}{|c|}{$\begin{array}{l}\text { Cultural modifications include irrigated land cover, pasture, and a water pipeline. The pastures add a sense of calm } \\
\text { but overgrazing adjacent to the site detracts giving a scenic rating of zero for Cultural Modifications. The improved } \\
\text { road surface to the north is noticeable from the site and the line is reinforced by telephone poles and barbed wire } \\
\text { fencing. The site is visible for nearly } 87 \text { seconds in the valley as one heads south towards the site. The route appears } \\
\text { to be well used by local residents. The view south from the pit is of ranch land but the site itself is not discernable. }\end{array}$} \\
\hline \multicolumn{7}{|c|}{ SCENIC QUALITY RATING } \\
\hline & & \multicolumn{5}{|c|}{ SCORE } \\
\hline \multicolumn{2}{|c|}{ LANDFORM } & 5 & 3 & 1 & \multicolumn{2}{|l|}{2} \\
\hline \multicolumn{2}{|c|}{ VEGETATION } & 5 & 3 & 1 & 4 & \\
\hline \multicolumn{2}{|l|}{ WATER } & 5 & 3 & 0 & 0 & \\
\hline \multicolumn{2}{|l|}{ COLOR } & 5 & 3 & 1 & 3 & \\
\hline \multicolumn{2}{|c|}{ ADJACENT SCENERY } & 5 & 3 & 0 & 3 & \\
\hline \multicolumn{2}{|l|}{ SCARCITY } & 5 & 3 & 1 & 3 & \\
\hline \multicolumn{2}{|c|}{ CULTURAL MODIFICATIONS } & 2 & 0 & -4 & 0 & \\
\hline \multicolumn{2}{|c|}{$\begin{array}{l}\text { TOTAL SCORE } \\
\end{array}$} & \multicolumn{5}{|c|}{$=15$} \\
\hline \multicolumn{2}{|c|}{$\begin{array}{l}\text { SCENIC QUALITY } \\
\text { CLASSIFICATION }\end{array}$} & \multicolumn{5}{|l|}{ B } \\
\hline
\end{tabular}




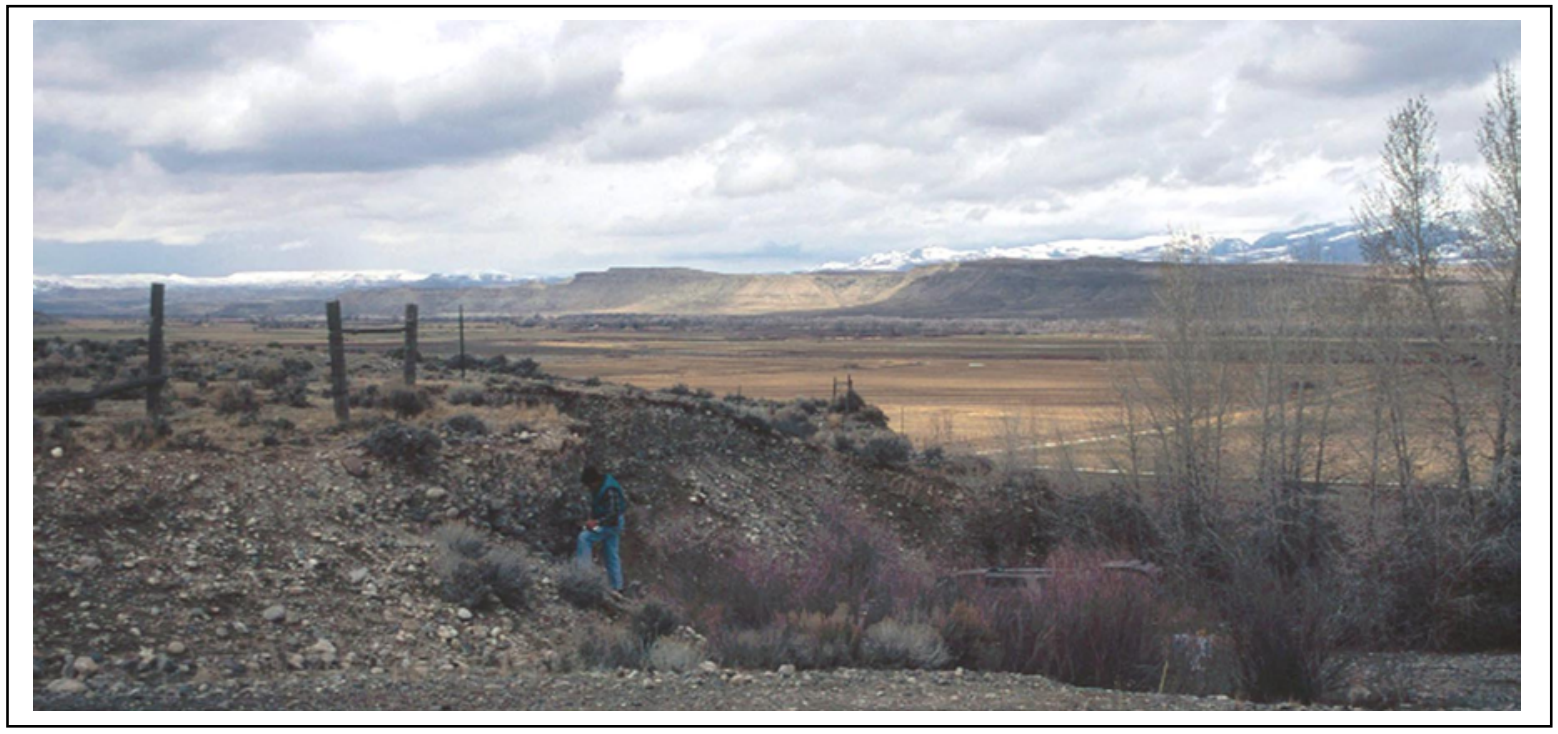

Upper, View northwest from terrace tread with exposed terrace face in foreground. Urbigket Road, riparian, and irrigated land cover occupy the middle ground. Owl Creek Mountains are to the right. Lower left, View east of north-facing terrace riser viewed from the road. Crowheart Butte is in the distance. Lower right, Overgrazed land cover on terrace tread, view northeast.
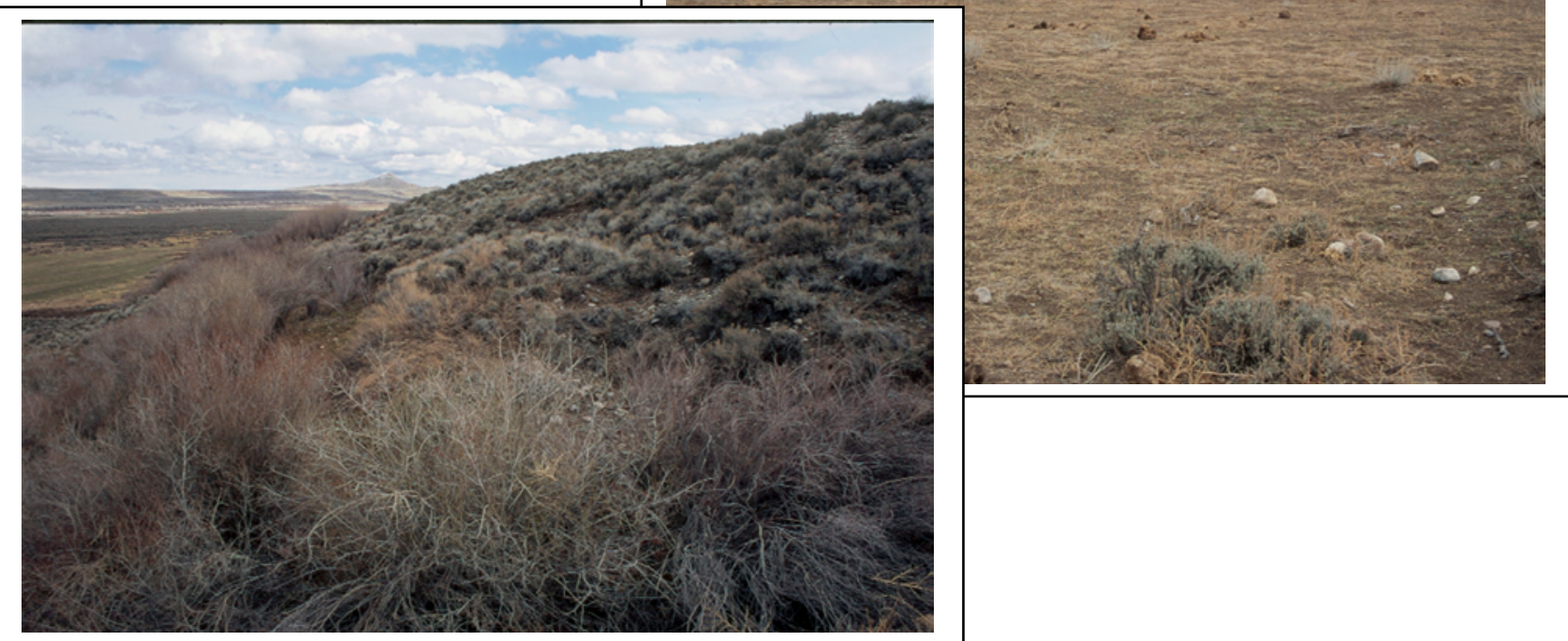
This page intentionally left blank.

A-43 


\section{Site Name: Kinnear}

Location: NW 1/4, NE 1/4, S30, T2N, R2E, Wind River Meridian

USGS Topographic Sheet: Pavillion

Date: 23 April 2005

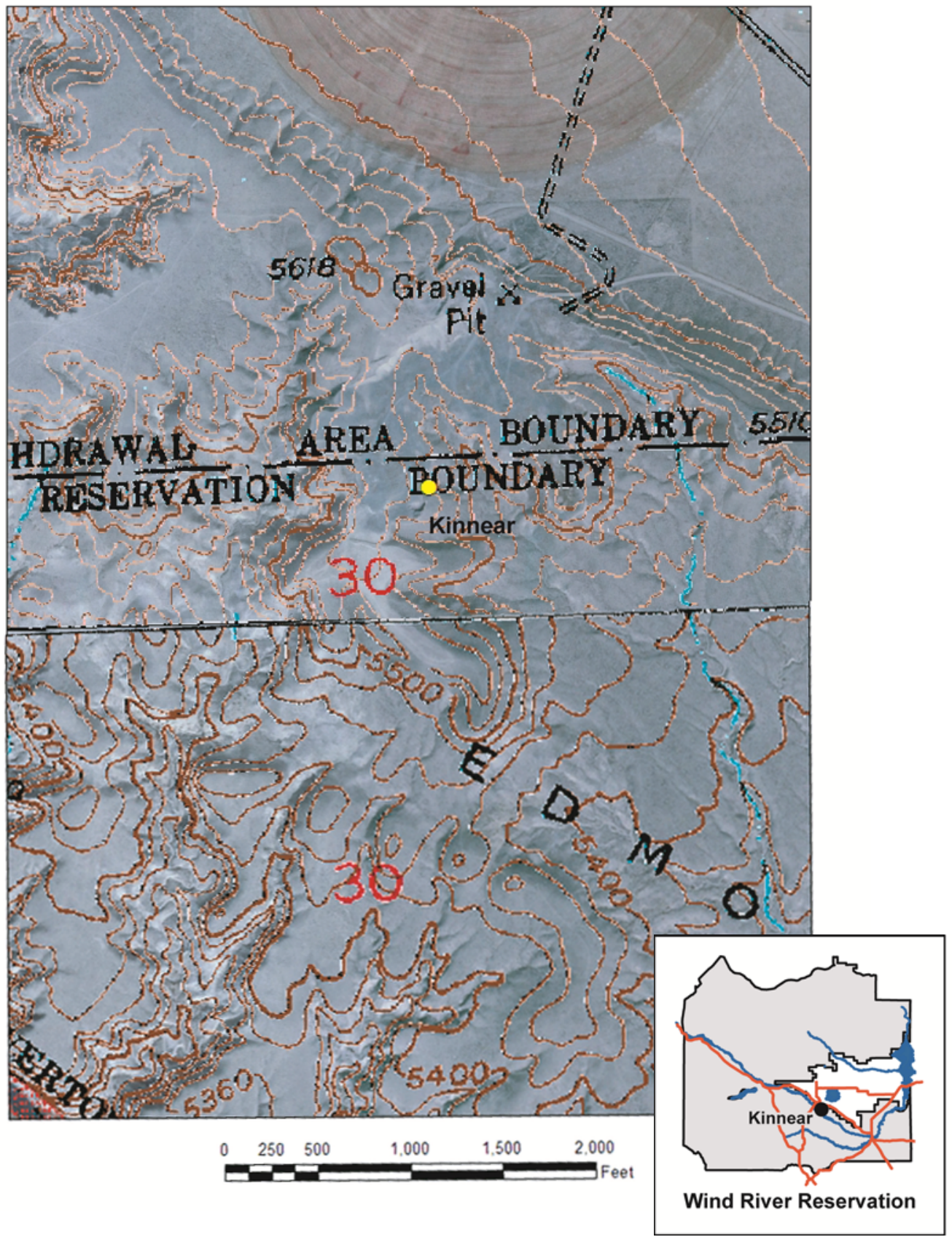




\begin{tabular}{|c|c|}
\hline \multicolumn{2}{|c|}{ GEOLOGIC DESCRIPTION } \\
\hline Sample number & $\# 1$ \\
\hline Location & $\begin{array}{c}43^{\circ} 07^{\prime} 36.8^{\prime \prime} \\
108^{\circ} 41^{\prime} 05.7^{\prime \prime}\end{array}$ \\
\hline Terrace level Qt & 8 \\
\hline Gravel thickness (feet) & 15 \\
\hline $\begin{array}{l}\text { Overburden thickness } \\
\text { (feet) }\end{array}$ & 1 \\
\hline Water table & None observed \\
\hline $\begin{array}{l}\text { Caliche thickness } \\
\text { (feet) }\end{array}$ & 3 \\
\hline $\begin{array}{l}\text { Maximum carbonate } \\
\text { stage }\end{array}$ & ॥ \\
\hline $\begin{array}{l}\text { Maximum clast } \\
\text { weathering }\end{array}$ & 4 \\
\hline \multicolumn{2}{|l|}{ Lithologies (pct) } \\
\hline Granite-gneiss & 29 \\
\hline $\begin{array}{l}\text { Mafic plutonic- } \\
\text { metamorphic }\end{array}$ & 5 \\
\hline Quartzite & 24 \\
\hline Vein quartz & - \\
\hline Sandstone & 12 \\
\hline Limestone & - \\
\hline Chert & Trace \\
\hline Volcanics & 30 \\
\hline Total & 100 \\
\hline
\end{tabular}

\begin{tabular}{|c|c|}
\hline \multicolumn{2}{|c|}{ ENGINEERING TESTS } \\
\hline Sample number & $\# 1$ \\
\hline $\begin{array}{l}\text { Maximum clast size } \\
\text { (inches) }\end{array}$ & 10 \\
\hline \multicolumn{2}{|c|}{ Size distribution (percent) } \\
\hline Cobbles & 15 \\
\hline Coarse Gravel & 40 \\
\hline Fine Gravel & 20 \\
\hline Sand & 23.6 \\
\hline Fines & 1.4 \\
\hline Total & 100 \\
\hline LA Value & 21.8 \\
\hline \multicolumn{2}{|l|}{ Soundness (pct) } \\
\hline$\leq 1.5^{\prime \prime}->0.75^{\prime \prime}$ & 0.2 \\
\hline$\leq 0.75^{\prime \prime}->0.375^{\prime \prime}$ & 0.2 \\
\hline$\leq 0.375$ - >\#4 sieve & 0.1 \\
\hline Specific gravity & 2.591 \\
\hline Percent absorption & 1.4 \\
\hline
\end{tabular}

\begin{tabular}{|l|c|}
\hline PRODUCTION CONSTANT & 15 \\
\hline Estimated gravel thickness (feet) & 34,485 \\
\hline Constant - Maximum recoverable product (tons per acre) & 23,512 \\
\hline Constant - Minimum recoverable product (tons per acre) & \\
\hline CONCLUSIONS & \\
\hline Portland cement concrete - May be suitable. Will require crushing and screening and may require \\
washing. Determine susceptibility to alkali-silica reaction. May require use of low-alkali cement or \\
additives. \\
Asphalt concrete - Suitable. Will require crushing and screening. \\
Base - Suitable. Will require crushing and screening. \\
\hline
\end{tabular}




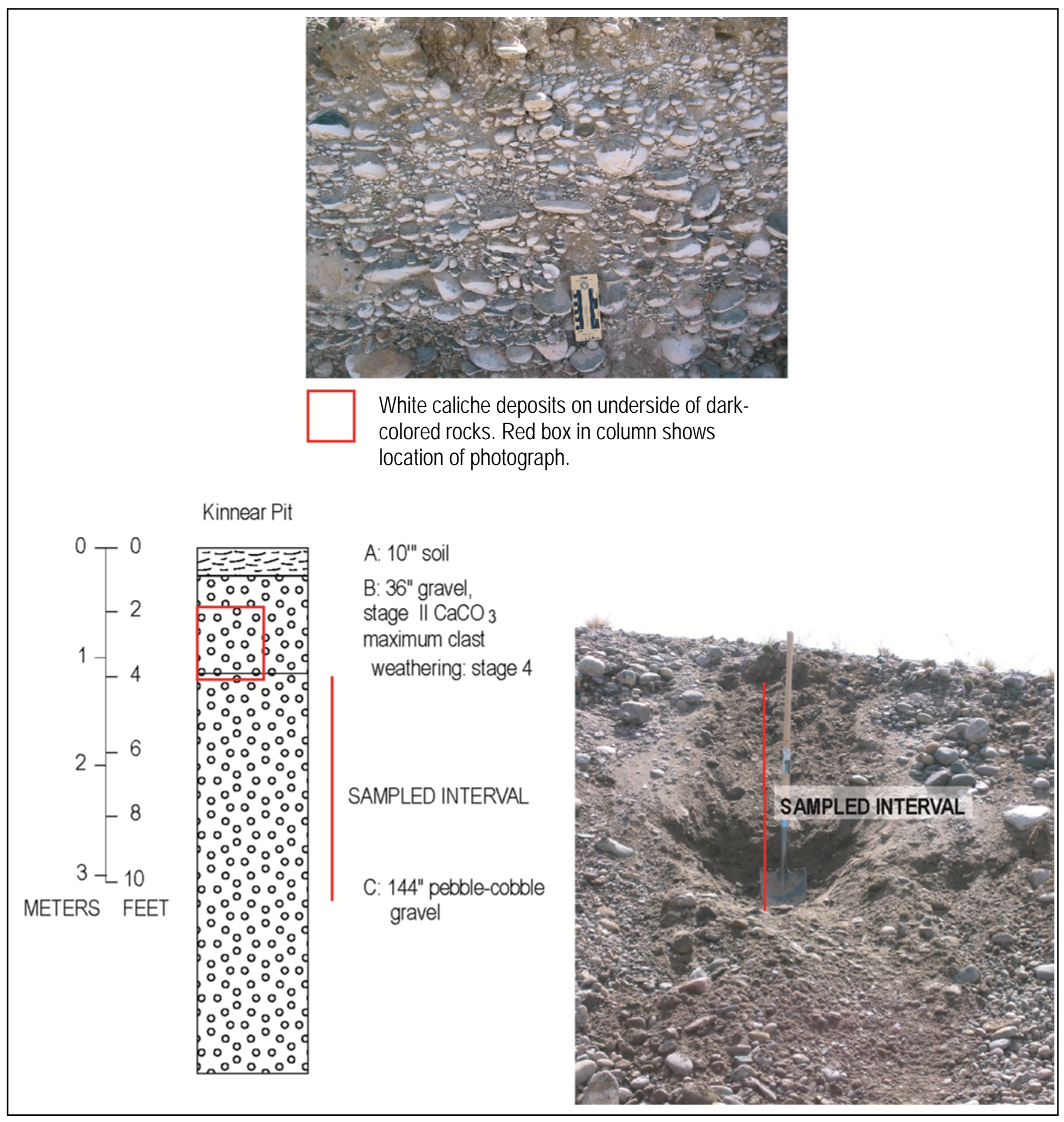




\begin{tabular}{|c|c|c|c|c|c|}
\hline \multirow{2}{*}{\multicolumn{6}{|c|}{ SCENIC QUALITY FIELD INVENTORY AND EVALUATION CHART }} \\
\hline & & & & & \\
\hline \multirow{2}{*}{\multicolumn{6}{|c|}{$\begin{array}{l}\text { Panoramic } \\
\text { LANDSCAPE ANALYSIS FACTORS }\end{array}$}} \\
\hline & & & & & \\
\hline \multicolumn{6}{|c|}{ The landscape has little contrast. } \\
\hline \multicolumn{6}{|c|}{ LANDSCAPE CHARACTER } \\
\hline & \multicolumn{2}{|c|}{ LANDFORM/WATER } & \multicolumn{2}{|c|}{ VEGETATION } & STRUCTURE \\
\hline FORM & \multicolumn{2}{|c|}{ Flat, long rectangular. } & \multicolumn{2}{|c|}{ Cushion, low, sparse. } & \\
\hline LINE & \multicolumn{2}{|c|}{$\begin{array}{l}\text { Gently curving, strong edge } \\
\text { terrace. }\end{array}$} & \multicolumn{2}{|l|}{ Indistinct. } & Short, interrupted (dirt road). \\
\hline COLOR & \multicolumn{2}{|l|}{ Tan, light brown. } & \multicolumn{2}{|c|}{ Tan, pale yellow, green. } & Grey, tan. \\
\hline TEXTURE & Smooth. & & Random sti & ium. & Rough. \\
\hline \multicolumn{6}{|c|}{ LANDSCAPE NARRATIVE } \\
\hline \multicolumn{6}{|c|}{$\begin{array}{l}\text { The Kinnear site (el } 5,540 \mathrm{ft} \text { ) is located approximately } 0.6 \mathrm{mi} \text { south of River Road. River Road connects with the } \\
\text { Ethete Cutoff, Hwy } 132 \text {. The site is nearly } 2 \text { mi east of Johnstown and approximately } 22 \text { mi from Riverton. }\end{array}$} \\
\hline \multicolumn{6}{|c|}{$\begin{array}{l}\text { The landform and vegetation are monotonous. Prairie plants are in spring bloom but they are too small and sparse to } \\
\text { create a color impact. Insects, butterflies and bees, are active. Cottonwoods and irrigated land is just visible in the } \\
\text { eastern middle ground. This would be more pronounced in the summer when the leaves are out. }\end{array}$} \\
\hline \multicolumn{6}{|c|}{$\begin{array}{l}\text { There are at least three sand and gravel pits, in the foreground, visible from the terrace top so a scenic rating of }-2 \text { was } \\
\text { given to Cultural Modifications. The site is not visible from below because the outside terrace rims were not altered. }\end{array}$} \\
\hline \multicolumn{6}{|c|}{ SCENIC QUALITY RATING } \\
\hline & & \multicolumn{4}{|c|}{ SCORE } \\
\hline \multicolumn{2}{|c|}{ LANDFORM } & 5 & 3 & 1 & 1 \\
\hline \multicolumn{2}{|c|}{ VEGETATION } & 5 & 3 & 1 & 2 \\
\hline \multicolumn{2}{|l|}{ WATER } & 5 & 3 & 0 & 0 \\
\hline \multicolumn{2}{|l|}{ COLOR } & 5 & 3 & 1 & 1 \\
\hline \multicolumn{2}{|c|}{ ADJACENT SCENERY } & 5 & 3 & 0 & 1 \\
\hline \multicolumn{2}{|l|}{ SCARCITY } & 5 & 3 & 1 & 1 \\
\hline \multicolumn{2}{|c|}{ CULTURAL MODIFICATIONS } & 2 & 0 & -4 & 2 \\
\hline TOTAL SC & & & & & \\
\hline $\begin{array}{l}\text { SCENIC Q } \\
\text { CLASSIFIC }\end{array}$ & $\begin{array}{l}\text { ALITY } \\
\text { ATION }\end{array}$ & C & & & \\
\hline
\end{tabular}



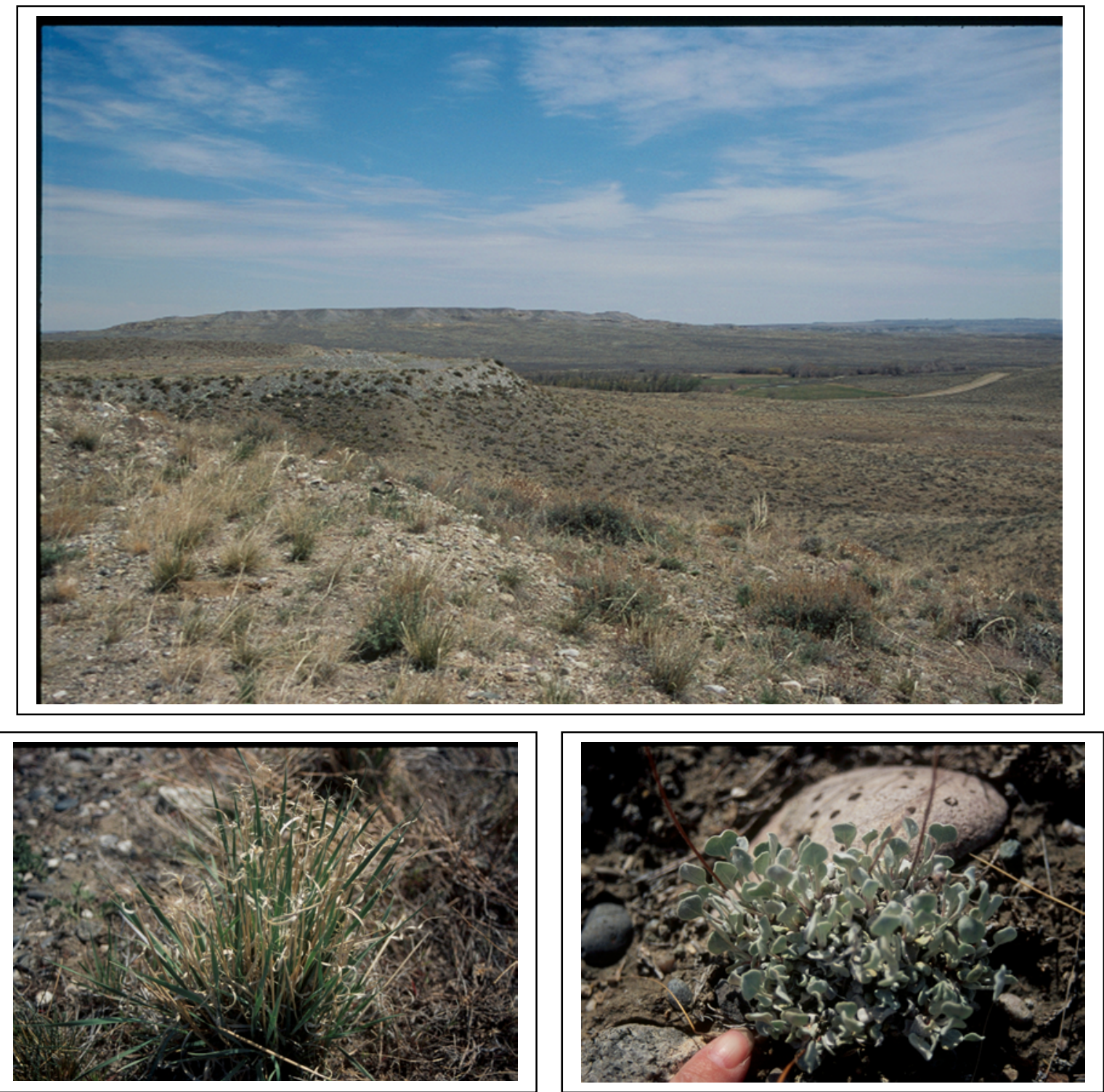

Upper, View east of an adjacent sand and gravel pit from the Kinnear site, River Road, riparian land cover in the middle ground, and Big Ridge in the back ground. Lower left, Typical grass. Lower right, Sulfur flower, possibly Eriogonum flavum. 

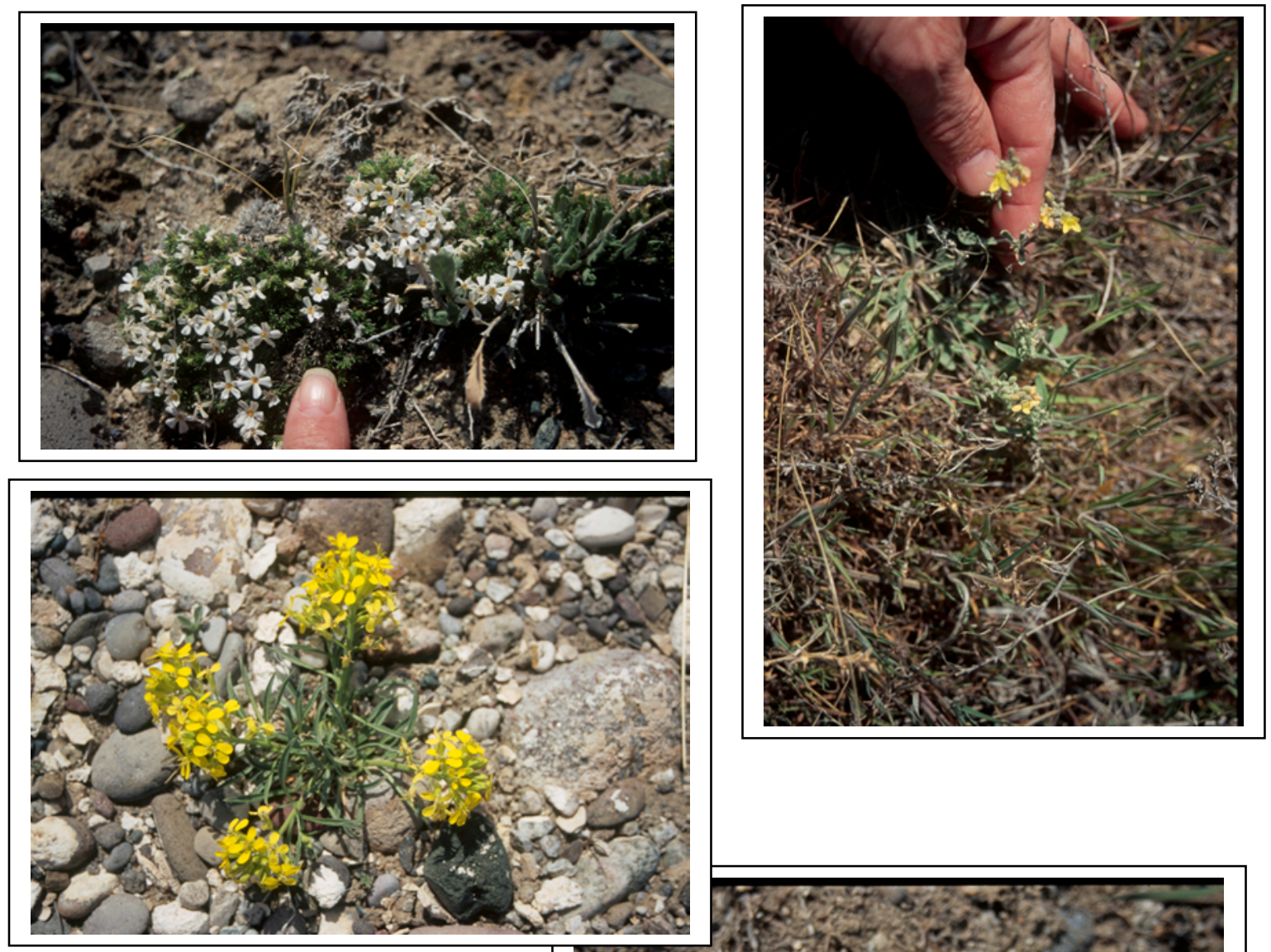

Clockwise from upper left, Hood's phlox, Phlox hoodii. A low cushion- or matforming forb. The second plant is possibly a Bladderpod, Lesquerella ssp. The third photo is possibly of Hymenopappus filifolius. The last image is of a Western wallflower, Erysimum asperum, a western North American species confined to plains and sagebrush steppes.

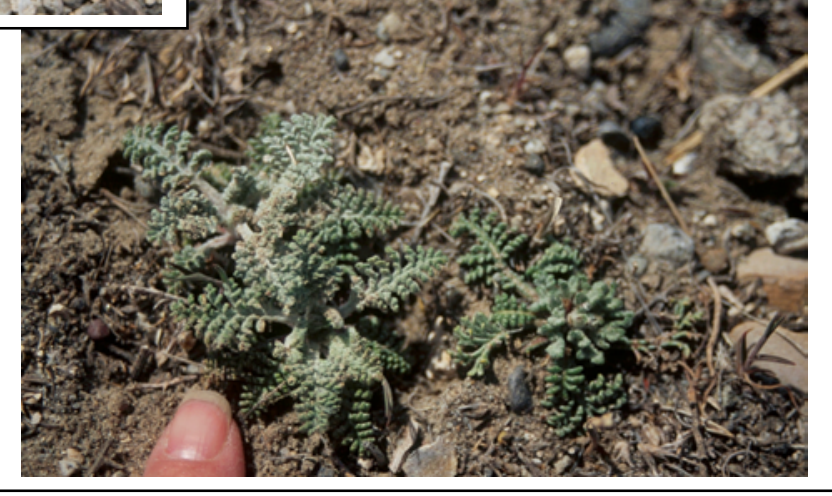




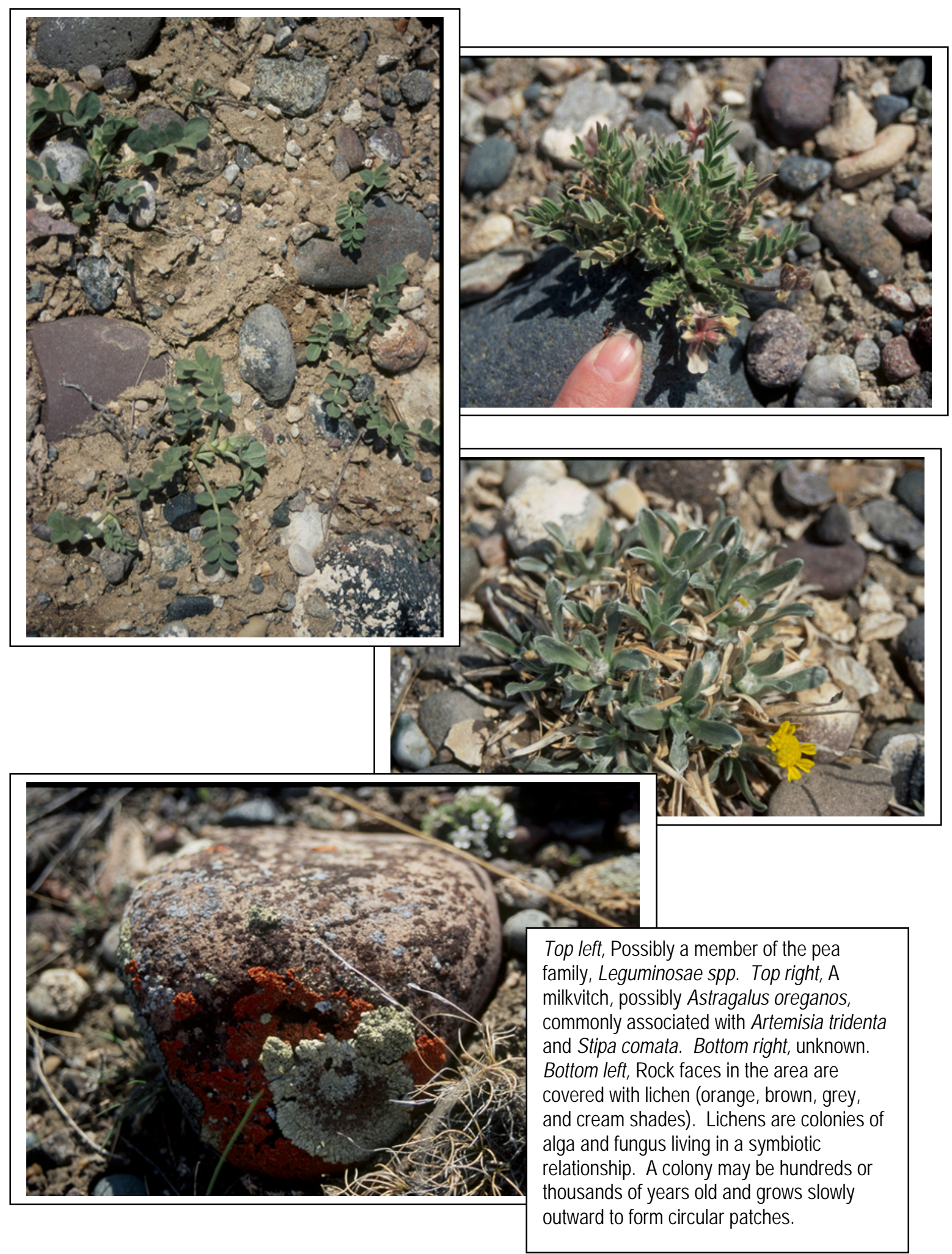


This page intentionally left blank.

A-51 
Site Name: Le Clair

Location: NE 1/4, SE 1/4, S33, T2N, R2E, Wind River Meridian USGS Topographic Sheet: Mule Butte

Date: 23 April 2005

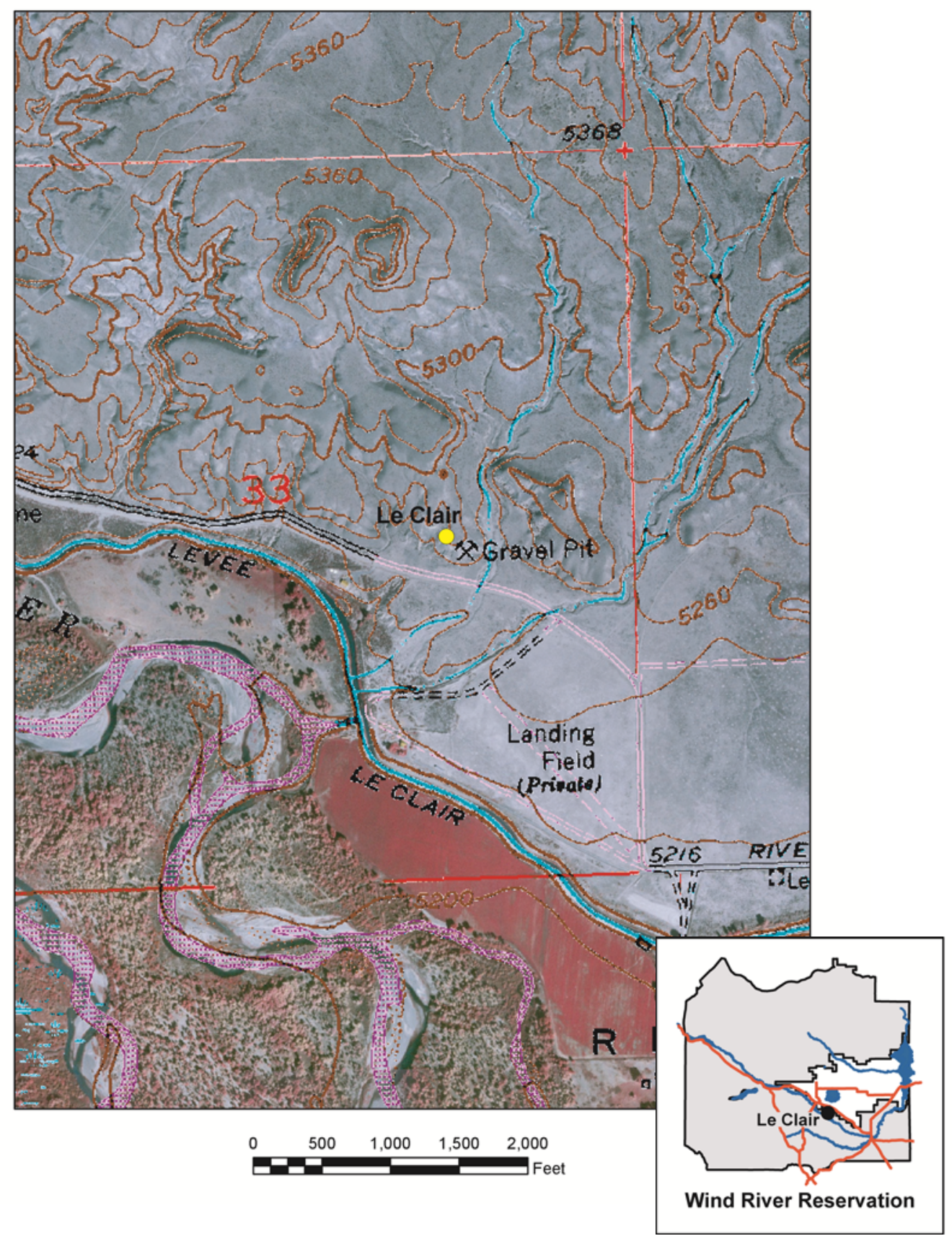


LE CLAIR: Sheet 2 of 5

\begin{tabular}{|c|c|}
\hline \multicolumn{2}{|c|}{ GEOLOGIC DESCRIPTION } \\
\hline Sample number & $\# 1$ \\
\hline Location: & $\begin{array}{c}43^{\circ} 06^{\prime} 19.9^{\prime \prime} \\
108^{\circ} 38^{\prime} 32.9^{\prime \prime}\end{array}$ \\
\hline Terrace level Qt & 2 \\
\hline Gravel thickness (feet) & 5 \\
\hline $\begin{array}{l}\text { Overburden thickness } \\
\text { (feet) }\end{array}$ & 6 \\
\hline Water table & None observed \\
\hline $\begin{array}{l}\text { Caliche thickness } \\
\text { (feet) }\end{array}$ & 2 \\
\hline $\begin{array}{l}\text { Maximum carbonate } \\
\text { stage }\end{array}$ & $\|$ \\
\hline $\begin{array}{l}\text { Maximum clast } \\
\text { weathering }\end{array}$ & 3 \\
\hline \multicolumn{2}{|l|}{ Lithologies (pct) } \\
\hline Granite-gneiss & 18 \\
\hline $\begin{array}{l}\text { Mafic plutonic- } \\
\text { metamorphic }\end{array}$ & 3 \\
\hline Quartzite & 26 \\
\hline Vein quartz & - \\
\hline Sandstone & 15 \\
\hline Limestone & Trace \\
\hline Chert & Trace \\
\hline Volcanics & 38 \\
\hline Total & 100 \\
\hline
\end{tabular}

\begin{tabular}{|c|c|}
\hline \multicolumn{2}{|c|}{ ENGINEERING TESTS } \\
\hline Sample number & $\# 1$ \\
\hline $\begin{array}{l}\text { Maximum clast size } \\
\text { (inches) }\end{array}$ & $>3$ \\
\hline \multicolumn{2}{|c|}{ Size distribution (percent) } \\
\hline Cobbles & 13 \\
\hline Coarse Gravel & 38 \\
\hline Fine Gravel & 20 \\
\hline Sand & 26.6 \\
\hline Fines & 2.4 \\
\hline Total & 100 \\
\hline LA Value: & 22.7 \\
\hline \multicolumn{2}{|l|}{ Soundness (pct) } \\
\hline$\leq 1.5^{\prime \prime}->0.75^{\prime \prime}$ & 0.3 \\
\hline$\leq 0.75^{\prime \prime}->0.375^{\prime \prime}$ & 0.4 \\
\hline$\leq 0.375$ - $>\# 4$ sieve & 0.3 \\
\hline Specific gravity & 2.553 \\
\hline Percent absorption & 1.5 \\
\hline
\end{tabular}

\begin{tabular}{|l|c|}
\hline PRODUCTION CONSTANT \\
\hline Estimated gravel thickness (feet) & 5 \\
\hline Constant - Maximum recoverable product (tons per acre) & 11,495 \\
\hline Constant - Minimum recoverable product (tons per acre) & 8,022 \\
\hline CONCLUSIONS \\
\hline Portland cement concrete - May be suitable. Will require crushing and screening and may require \\
washing. Determine susceptibility to alkali-silica reaction. May require use of low-alkali cement or additives. \\
Asphalt concrete - Suitable. Will require crushing and screening. \\
Base - Suitable. Will require crushing and screening. \\
Difficult mining - This property has small, isolated deposits of gravel, which might complicate mining \\
efforts \\
\hline
\end{tabular}


LE CLAIR: Sheet 3 of 5

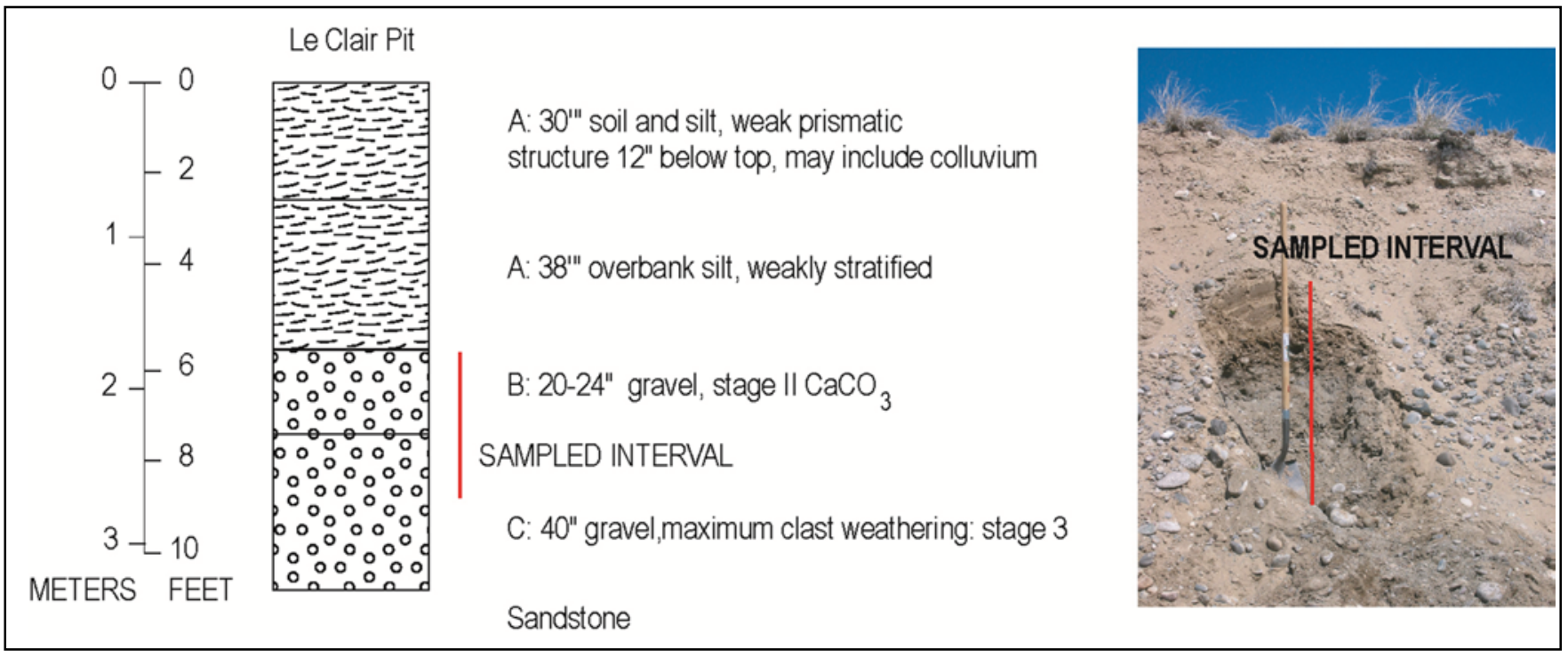


LE CLAIR: Sheet 4 of 5

\begin{tabular}{|c|c|c|c|c|c|c|c|}
\hline \multicolumn{8}{|c|}{\begin{tabular}{|l} 
SCENIC QUALITY FIELD INVENTORY AND EVALUATION CHART \\
LANDSCAPE TYPE
\end{tabular}} \\
\hline \multicolumn{8}{|c|}{ Panoramic } \\
\hline \multicolumn{8}{|c|}{ LANDSCAPE ANALYSIS FACTORS } \\
\hline \multirow{2}{*}{\multicolumn{8}{|c|}{$\begin{array}{l}\text { Line sequence from systematic repetition of vegetative patterns (cottonwoods). } \\
\text { LANDSCAPE CHARACTER }\end{array}$}} \\
\hline & & & & & & & \\
\hline & \multirow{2}{*}{\multicolumn{2}{|c|}{$\begin{array}{l}\text { LANDFORM/WATER } \\
\text { Gentle slope, trapezoid } \\
\text { (sandstone), boulders (Wind } \\
\text { River Formation). }\end{array}$}} & \multicolumn{4}{|c|}{ VEGETATION } & STRUCTURE \\
\hline FORM & & & \multicolumn{4}{|c|}{$\begin{array}{l}\text { Sparse small grasses, cushions. Long } \\
\text { tapering cylinder (cottonwoods). }\end{array}$} & Rectangular. \\
\hline LINE & \multicolumn{2}{|l|}{ Curving. } & \multicolumn{4}{|c|}{$\begin{array}{l}\text { Undulating band cutting area in two } \\
\text { (grazed and sagebrush land cover). } \\
\text { Diagonal. }\end{array}$} & $\begin{array}{l}\text { Vertical, horizontal, sequence } \\
\text { from fencing and road. }\end{array}$ \\
\hline COLOR & \multicolumn{2}{|c|}{ Eggshell, sand, pale orange. } & \multicolumn{4}{|c|}{ Sage green (cool dull colors retreat). } & $\begin{array}{l}\text { Red, yellow, white, shiny } \\
\text { (warm bright colors advance.) }\end{array}$ \\
\hline TEXTURE & \multicolumn{2}{|c|}{ Fine ground plane, smooth. } & \multicolumn{4}{|c|}{$\begin{array}{l}\text { Clumps, uneven, rough in foreground, } \\
\text { fine in middle ground. }\end{array}$} & Smooth. \\
\hline \multicolumn{8}{|c|}{ LANDSCAPE NARRATIVE } \\
\hline \multirow{2}{*}{\multicolumn{8}{|c|}{$\begin{array}{l}\text { The Le Clair site (el } 5,280 \mathrm{ft} \text { ) is approximately } 18 \mathrm{mi} \text { from Riverton via River Road. The Wind River and Le Clair Canal } \\
\text { are only } 0.3 \mathrm{mi} \text { away. The foreground and middle ground objects do not substantially block viewing. A private landing } \\
\text { field shows on the land cover map less than } 0.5 \text { mi southeast of the site. } \\
\text { The vegetation includes prickleypear cactus, rubber rabbitbrush or sand sage, and larger specimens of sagebrush in } \\
\text { the draws. Cow pies and snake skins are in evidence. The variety of Adjacent Scenery, (including cottonwoods, } \\
\text { irrigated fields, sandstone formations, and a historic gravel tip), give a scenic rating of } 5 \text {. }\end{array}$}} \\
\hline & & & & & & & \\
\hline \multicolumn{8}{|c|}{ The site is in view from the dirt road for $3 \mathrm{sec}$ and is in plain view of the homes opposite. Local traffic was noted. } \\
\hline \multicolumn{8}{|c|}{ SCENIC QUALITY RATING } \\
\hline & & & \multicolumn{5}{|c|}{ SCORE } \\
\hline \multicolumn{2}{|c|}{ LANDFORM } & & 5 & 3 & 1 & \multicolumn{2}{|c|}{1} \\
\hline \multicolumn{2}{|c|}{ VEGETATION } & & 5 & 3 & 1 & \multicolumn{2}{|l|}{2} \\
\hline \multicolumn{2}{|l|}{ WATER } & & 5 & 3 & 0 & \multicolumn{2}{|l|}{0} \\
\hline \multicolumn{2}{|l|}{ COLOR } & & 5 & 3 & 1 & \multicolumn{2}{|l|}{2} \\
\hline \multicolumn{2}{|c|}{ ADJACENT SCENERY } & & 5 & 3 & 0 & \multicolumn{2}{|l|}{5} \\
\hline \multicolumn{2}{|c|}{ SCARCITY } & & 5 & 3 & 1 & \multicolumn{2}{|l|}{2} \\
\hline \multicolumn{2}{|c|}{ CULTURAL MODIFICATIONS } & & 2 & 0 & -4 & 1 & \\
\hline TOTAL SC & $\overline{\mathrm{PRE}}$ & & & & & $=13$ & \\
\hline $\begin{array}{l}\text { SCENIC Q } \\
\text { CLASSIFIC }\end{array}$ & $\begin{array}{l}\text { ALITY } \\
\text { ATION }\end{array}$ & $\bar{B}$ & & & & & \\
\hline
\end{tabular}




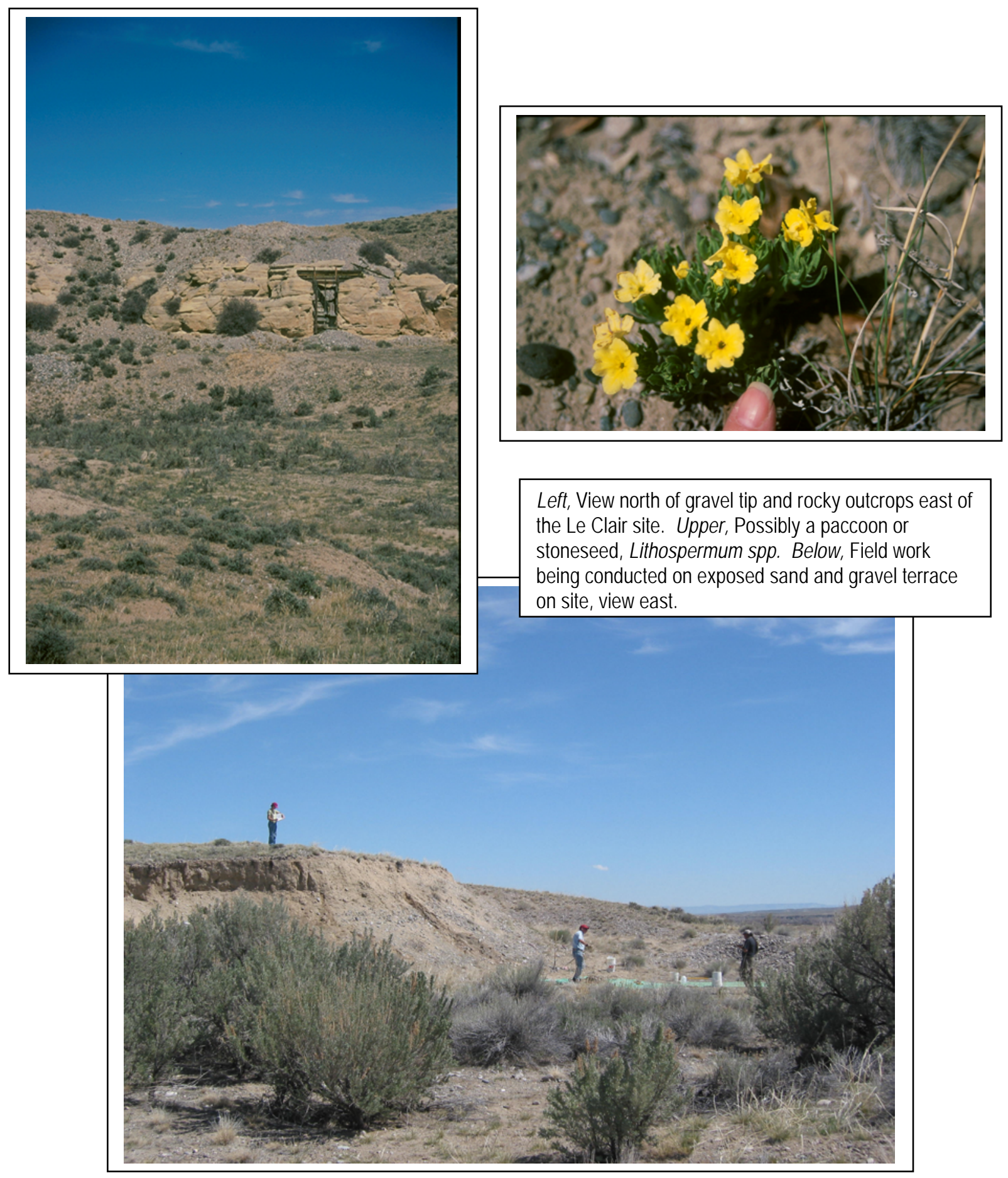


This page intentionally left blank. 


\section{Site Name: Red Rocks}

Location: NE1/4, SW11/4, S11, T5N, R6W, Wind River Meridian

USGS Topographic Sheet: Blue Holes

Date: 24 April 2005

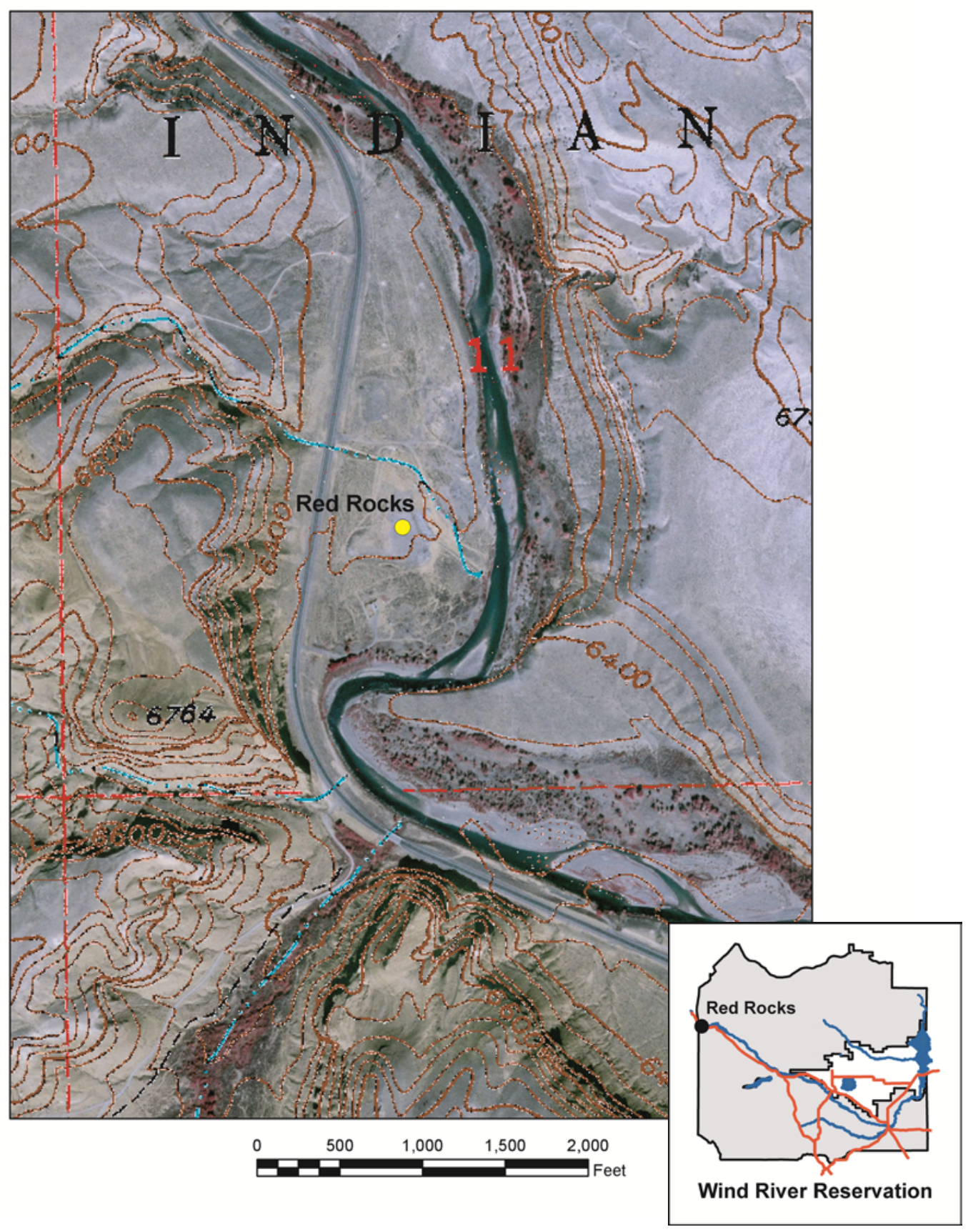




\begin{tabular}{|c|c|c|c|c|c|}
\hline \multicolumn{6}{|c|}{ GEOLOGIC OBSERVATIONS } \\
\hline Investigator & USGS & \multicolumn{3}{|c|}{ HMK Engineering* } & \multirow{2}{*}{$\begin{array}{c}\text { General site } \\
\text { characteristics }\end{array}$} \\
\hline Sample number: & $\# 1$ & $\begin{array}{c}\text { Red Rocks \# } \\
2,3\end{array}$ & $\begin{array}{c}\text { Red Rocks \# } \\
5,6\end{array}$ & $\begin{array}{c}\text { Red Rocks } \\
\text { Average } 7 \\
\text { samples }\end{array}$ & \\
\hline Location & $\begin{array}{c}43^{\circ} 25^{\prime} 20.7^{\prime \prime} \\
109^{\circ} 26^{\prime} 28.5^{\prime \prime}\end{array}$ & - & - & - & - \\
\hline Terrace level Qt & 2 & - & - & - & 2 \\
\hline Gravel thickness (feet) & 20 & $>7$ & $>6$ & - & 20 \\
\hline $\begin{array}{l}\text { Overburden thickness } \\
\text { (feet) }\end{array}$ & 1 & $1.3-1.4$ & $2.9-7.1$ & - & 1 \\
\hline Water table & Near river level & - & - & - & \\
\hline $\begin{array}{l}\text { Caliche thickness } \\
\text { (feet) }\end{array}$ & 2 & - & - & - & 2 \\
\hline $\begin{array}{l}\text { Maximum carbonate } \\
\text { stage: }\end{array}$ & II & - & - & - & II \\
\hline $\begin{array}{l}\text { Maximum clast } \\
\text { weathering: }\end{array}$ & 3 & - & - & - & 3 \\
\hline \multicolumn{6}{|l|}{ Lithologies (pct) } \\
\hline Granite-gneiss & 23 & - & - & - & 23 \\
\hline $\begin{array}{l}\text { Mafic plutonic- } \\
\text { metamorphic }\end{array}$ & 3 & - & - & - & 3 \\
\hline Quartzite & 6 & - & - & - & 6 \\
\hline Vein quartz & - & - & - & - & - \\
\hline Sandstone & 25 & - & - & - & 25 \\
\hline Limestone & 13 & - & - & - & 13 \\
\hline Chert & - & - & - & - & - \\
\hline Volcanics & 30 & - & - & - & 30 \\
\hline Total & 100 & - & - & - & 100 \\
\hline
\end{tabular}

* Eastern Shoshone Oil \& Gas Commission, 2005 


\begin{tabular}{|c|c|c|c|c|c|}
\hline \multicolumn{6}{|c|}{ ENGINEERING TESTS } \\
\hline Investigator & USGS & \multicolumn{3}{|c|}{ HMK Engineering* } & \multirow[b]{2}{*}{$\begin{array}{c}\text { General site } \\
\text { characteristics }\end{array}$} \\
\hline Sample number & $\# 1$ & $\begin{array}{c}\text { Red Rocks \# } \\
2,3\end{array}$ & $\begin{array}{c}\text { Red Rocks \# } \\
5,6\end{array}$ & $\begin{array}{c}\text { Red Rocks } \\
\text { Average } 7 \\
\text { samples }\end{array}$ & \\
\hline \multicolumn{6}{|l|}{ Grain Size Analysis: } \\
\hline $\begin{array}{l}\text { Maximum clast size } \\
\text { (inches) }\end{array}$ & 62 & - & - & - & 62 \\
\hline \multicolumn{6}{|c|}{ Size distribution (percent) } \\
\hline Cobbles & - & - & - & 30 & 30 \\
\hline Coarse Gravel & - & - & - & 25 & 25 \\
\hline Fine Gravel & - & - & - & 14 & 14 \\
\hline Sand & - & - & - & 27 & 27 \\
\hline Fines & - & - & - & 4 & 4 \\
\hline Total & - & - & - & 100 & 100 \\
\hline LA Value & - & 27.2 & 26.8 & - & 27 \\
\hline \multicolumn{6}{|l|}{ Soundness } \\
\hline$\leq 1.5^{\prime \prime}->0.75^{\prime \prime}$ & - & 1.5 & 1.2 & - & 1.35 \\
\hline$\leq 0.75^{\prime \prime}->0.375^{\prime \prime}$ & - & 3.9 & 2.6 & - & 3.25 \\
\hline$\leq 0.375$ - $>\# 4$ sieve & - & - & - & - & - \\
\hline Specific gravity & - & 2.605 & 2.591 & - & 2.598 \\
\hline Percent absorption & - & 1.24 & 1.12 & - & 1.18 \\
\hline
\end{tabular}

\begin{tabular}{|c|c|}
\hline \multicolumn{2}{|l|}{ PRODUCTION CONSTANT } \\
\hline Estimated gravel thickness (feet) & 20 \\
\hline Constant - Maximum recoverable product & 45,980 \\
\hline Constant - Minimum recoverable product & 25,817 \\
\hline \multicolumn{2}{|l|}{ CONCLUSIONS } \\
\hline \multicolumn{2}{|c|}{$\begin{array}{l}\text { Portland cement concrete - May be suitable. Will require crushing and screening and may require } \\
\text { washing. Determine susceptibility to alkali-silica reaction. May require use of low-alkali cement or } \\
\text { additives. } \\
\text { Asphalt concrete - Suitable. Will require crushing and screening. } \\
\text { Base - Suitable. Will require crushing and screening. } \\
\text { Difficult Mining - The large boulders will be difficult to handle with conventional equipment and may } \\
\text { complicate mining. However, it might be possible to set aside the boulders and sell them as landscaping } \\
\text { rock or rip-rap. Smaller cobbles may have to be removed with a grizzly screen. }\end{array}$} \\
\hline
\end{tabular}


RED ROCKS: Sheet 4 of 8

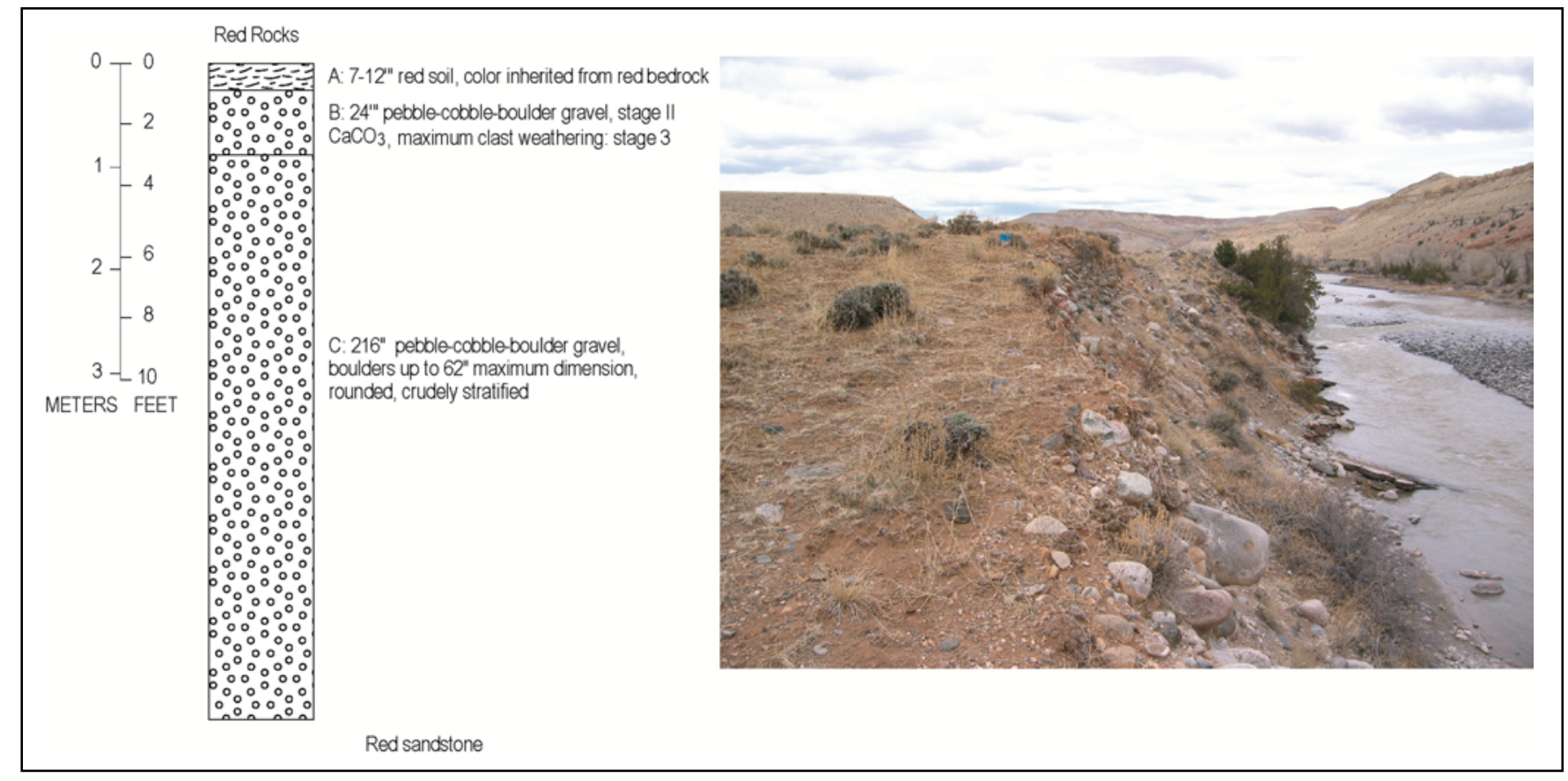


RED ROCKS: Sheet 5 of 8

This page intentionally left blank. 


\begin{tabular}{|c|c|c|c|c|c|c|}
\hline \multicolumn{7}{|c|}{ SCENIC QUALITY FIELD INVENTORY AND EVALUATION CHART } \\
\hline \multicolumn{7}{|c|}{ LANDSCAPE TYPE } \\
\hline \multicolumn{7}{|c|}{ Enclosed_Landscape elements form "wall" and "floor." } \\
\hline \multicolumn{7}{|c|}{ LANDSCAPE ANALYSIS FACTORS } \\
\hline \multirow{2}{*}{\multicolumn{7}{|c|}{$\begin{array}{l}\text { Contrast due to red rocks and yellow earth; soil and large boulders; evergreens and grasses. Enframement created by } \\
\text { slopes on either side. Intimate scale makes objects within area appear larger. } \\
\text { LANDSCAPE CHARACTER }\end{array}$}} \\
\hline & & & & & & \\
\hline & \multicolumn{3}{|c|}{ LANDFORM/WATER } & \multicolumn{2}{|c|}{ VEGETATION } & STRUCTURE \\
\hline FORM & \multicolumn{3}{|c|}{$\begin{array}{l}\text { Gently sloping surfaces above relatively } \\
\text { narrow flood plain; interesting drainage } \\
\text { areas closely spaced. Slopes take on } \\
\text { visual importance. }\end{array}$} & \multicolumn{2}{|c|}{$\begin{array}{l}\text { Few rounded sage and some } \\
\text { grasses. Picturesque junipers } \\
\text { concentrated along water. } \\
\text { Rubber rabbit brush in hollows. }\end{array}$} & $\begin{array}{l}\text { Rectangular (mobile } \\
\text { home). }\end{array}$ \\
\hline LINE & \multicolumn{3}{|c|}{$\begin{array}{l}\text { Strong horizontal banding of rocks; linear } \\
\text { and directional movement of water. }\end{array}$} & \multicolumn{2}{|c|}{ Interrupted line parallel to river. } & None. \\
\hline COLOR & \multicolumn{3}{|c|}{$\begin{array}{l}\text { Bold red-orange in the exposed } \\
\text { sandstone, gray river rock, yellow. }\end{array}$} & \multicolumn{2}{|c|}{ Dark green, tan, grey. } & White, light blue. \\
\hline TEXTURE & \multicolumn{3}{|c|}{$\begin{array}{l}\text { Coarse stone along river, fine middle } \\
\text { ground. }\end{array}$} & \multicolumn{2}{|c|}{$\begin{array}{l}\text { Medium, sparse density in trees } \\
\text { and shrubs; fine, medium density } \\
\text { in forbs and grasses. }\end{array}$} & Fine, reflective. \\
\hline \multicolumn{7}{|c|}{ LANDSCAPE NARRATIVE } \\
\hline \multicolumn{7}{|c|}{$\begin{array}{l}\text { The Red Rocks site is located in a narrow valley floor (approximately } 0.3 \text { miles wide) and is adjacent to the Wind River } \\
\text { and U.S. Highway } 26 / 287 \text {. Lander is approximately } 60 \text { mi southeast. Two Wildlife Habitat Management Areas and } \\
\text { the Shoshone National Forest are within } 5 \text { mi. Elevation differences within the foreground range from approximately } \\
6,380 \text { to } 6,600 \text { ft. Views from the area are obstructed by the surrounding topography. The sky appears reduced to a } \\
\text { smaller area overhead. }\end{array}$} \\
\hline \multicolumn{7}{|c|}{$\begin{array}{l}\text { The landforms give the area an appearance of a small space. Due to the sense of enclosure, the landscape within } \\
\text { the river valley is vulnerable to modification. The lines in the area are strongly horizontal in nature. They are formed } \\
\text { by the shape of the terraces, striations in the sedimentary rock, and the strong contrast in color. Erosional processes } \\
\text { are evident with naturally occurring areas of bare rock and soil. An abandoned pit is discernable. Rounded river rock } \\
\text { is evident. }\end{array}$} \\
\hline \multirow{2}{*}{\multicolumn{7}{|c|}{$\begin{array}{l}\text { The existing vegetation cover is dominated by grasses, while sparse in some areas, and includes: cottonwood-willow } \\
\text { riparian habitat (streamside), conifer, and sagebrush. Western riparian ecosystems are considered essential habitat for } \\
\text { many vertebrate species. The dominant color for much of the year is tan; green during the summer. The texture of the } \\
\text { vegetation appears fine in the immediate foreground and medium in the middle distance. } \\
\text { The site is in view by highway users approximately } 10 \text { seconds heading north. Heading south, the site is visible for } 32 \\
\text { seconds. Approximately } 10 \text { more seconds would be hidden by summer foliage of deciduous trees. }\end{array}$}} \\
\hline & & & & & & \\
\hline \multicolumn{7}{|c|}{ SCENIC QUALITY RATING } \\
\hline \multirow{2}{*}{\multicolumn{2}{|c|}{ LANDFORM }} & \multicolumn{5}{|c|}{ SCORE } \\
\hline & & 5 & 3 & 1 & 5 & \\
\hline \multicolumn{2}{|c|}{ VEGETATION } & 5 & 3 & 1 & 5 & \\
\hline \multicolumn{2}{|l|}{ WATER } & 5 & 3 & 0 & 5 & \\
\hline \multicolumn{2}{|l|}{ COLOR } & 5 & 3 & 1 & 5 & \\
\hline \multicolumn{2}{|c|}{ ADJACENT SCENERY } & 5 & 3 & 0 & 0 & \\
\hline \multicolumn{2}{|c|}{ SCARCITY } & 5 & 3 & 0 & 5 & \\
\hline \multicolumn{2}{|c|}{ CULTURAL MODIFICATIONS } & 2 & 0 & -4 & -2 & \\
\hline \multicolumn{2}{|c|}{ TOTAL SCORE } & \multicolumn{5}{|c|}{$=23$} \\
\hline \multicolumn{2}{|c|}{$\begin{array}{l}\text { SCENIC QUALITY } \\
\text { CLASSIFICATION }\end{array}$} & $\bar{A}$ & & & & \\
\hline
\end{tabular}



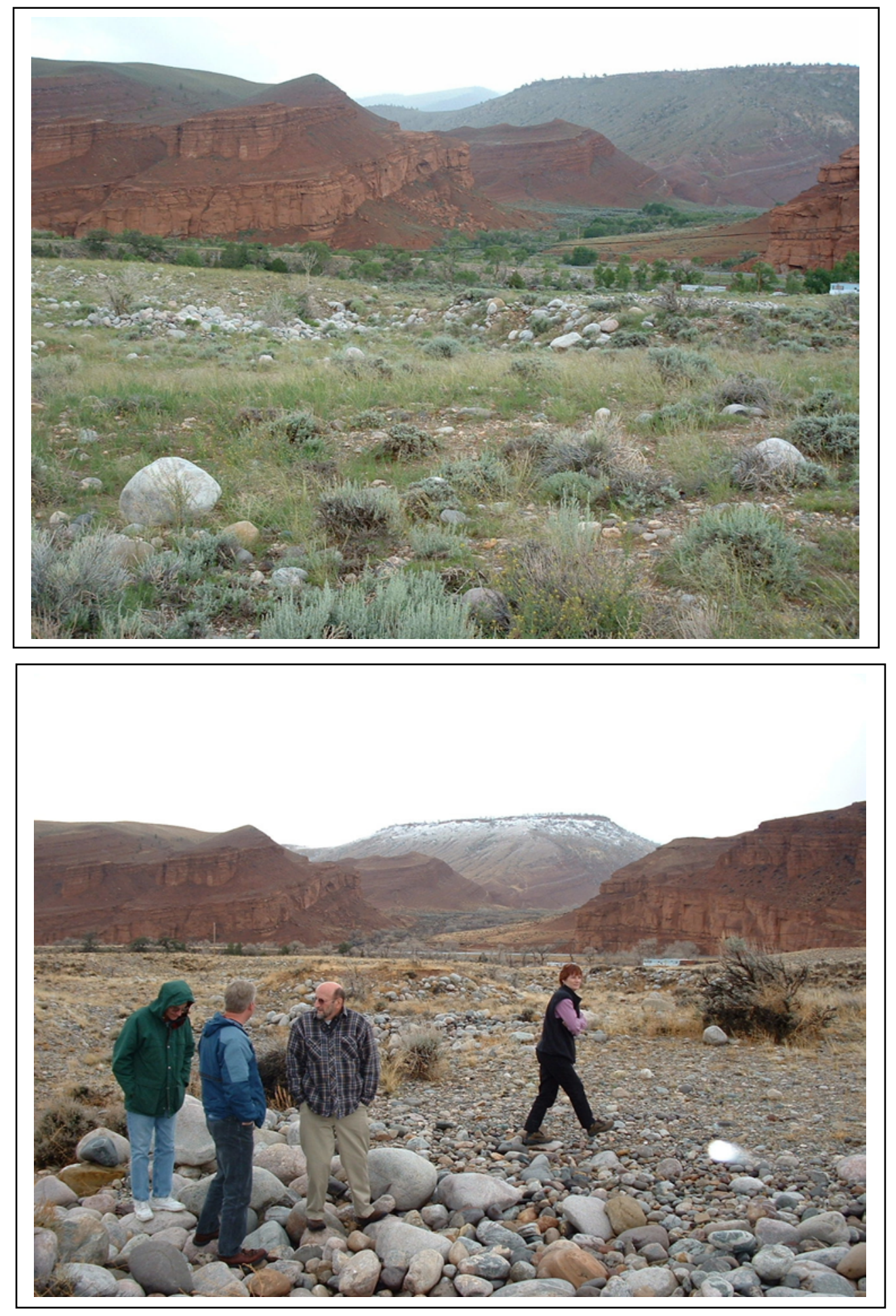

The two photographs above were taken from approximately the same location but at different times of the year. They illustrate how much greener the habitat is in August than April. The deciduous vegetation along U.S. Hwy 26/287 camouflages the site from vehicular observers more in the summer than the rest of the year. (Both photographs courtesy of Floyd Phillips.) 


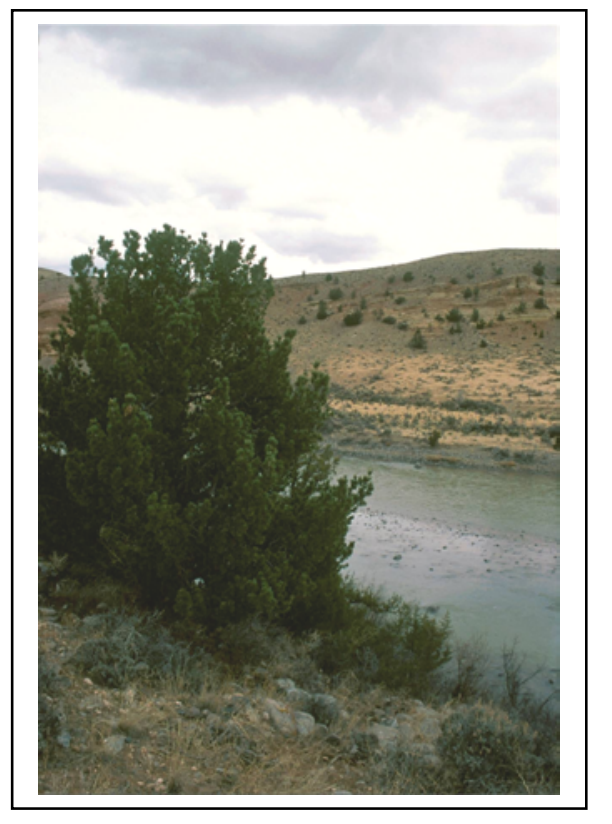

RED ROCKS: Sheet 8 of 8

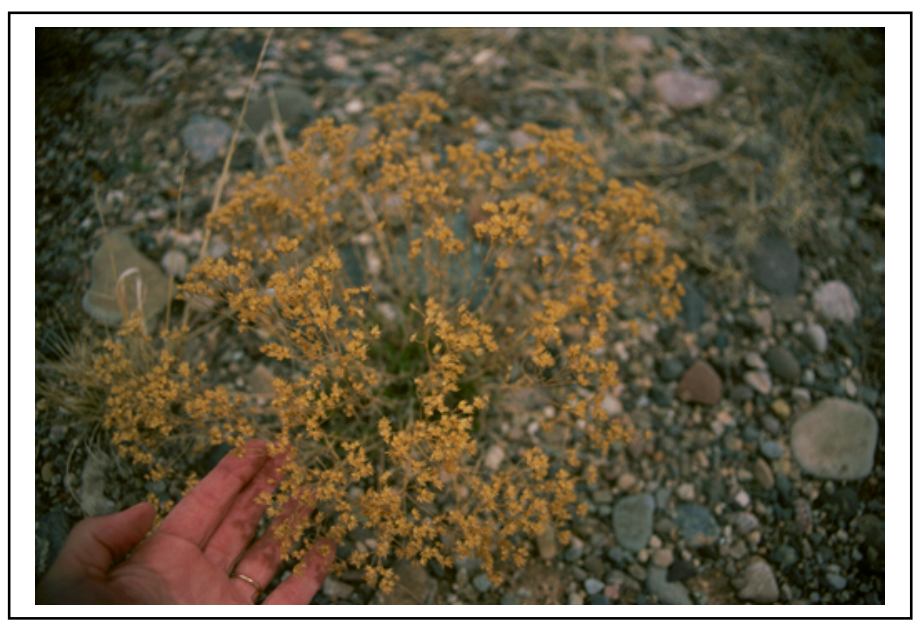

Upper left, View of the Wind River looking northeast from the Red Rocks site. Conifers (including pines and junipers) are scattered across the area in small groups. Upper right, Last season's dried seed heads are of broom snakeweed (Gutierrezia sarothrae). It is a native perennial found in plant communities of wheatgrass, sagebrush, and short grasses. Below, Exposed red sandstone bluffs, cottonwood species, and surrounding terraces are visible to the southeast. Gravel bar is visible in the Wind River.

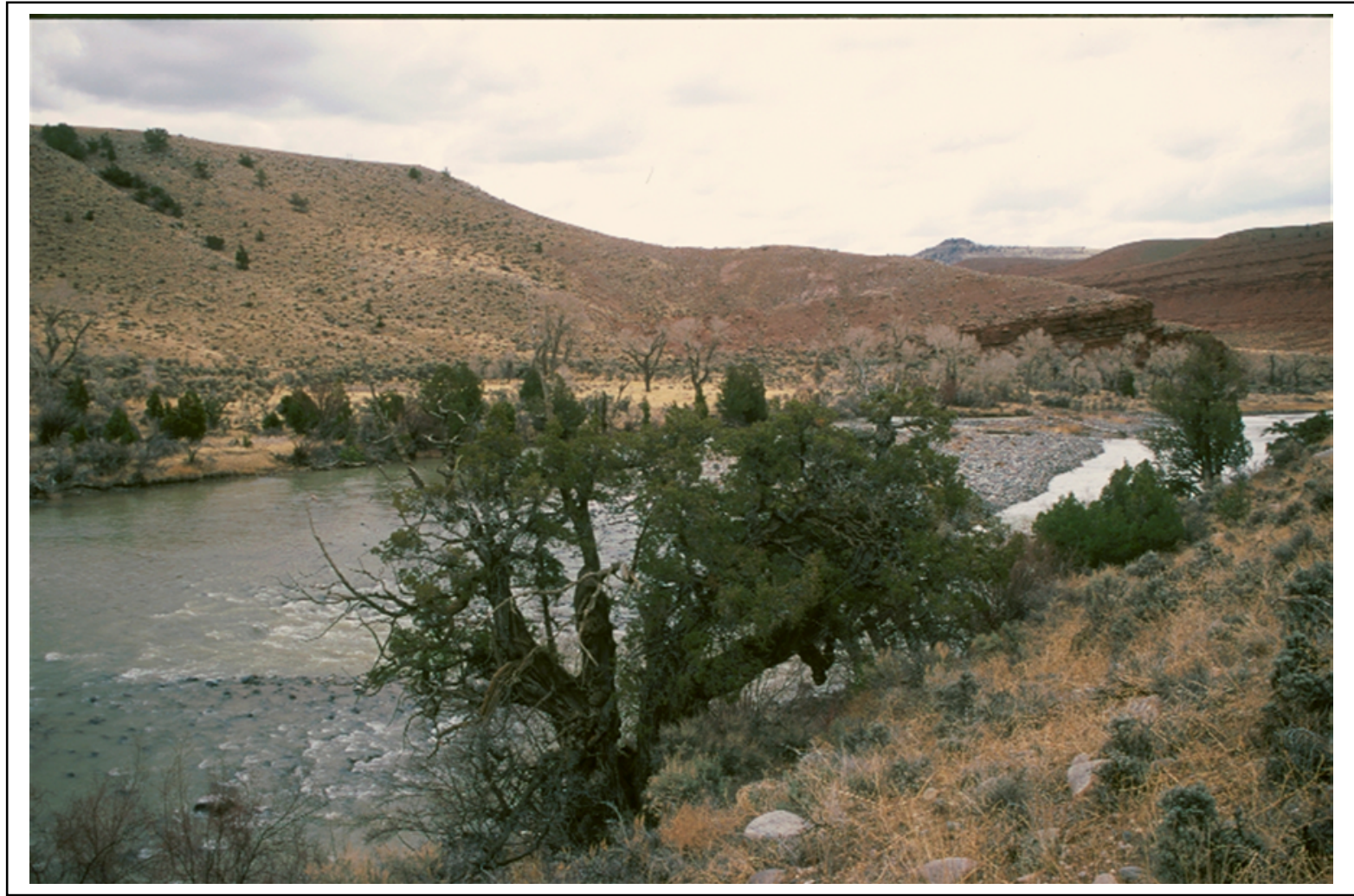


Site Name: Sheer Pit

Location: NW 1/4, SE 1/4, S16, T3N, R1W, Wind River Meridian

USGS Topographic Sheet: Argo Butte

Date: 22 April 2005






\begin{tabular}{|c|c|}
\hline \multicolumn{2}{|c|}{ GEOLOGIC DESCRIPTION } \\
\hline Sample number & $\# 1$ \\
\hline Location & $\begin{array}{l}43^{\circ} 14^{\prime} 03.5^{\prime \prime} \\
108^{\circ} 52^{\prime} 44.6^{\prime \prime}\end{array}$ \\
\hline Terrace level Qt & 5 \\
\hline Gravel thickness (feet) & 10 \\
\hline $\begin{array}{l}\text { Overburden thickness } \\
\text { (feet) }\end{array}$ & 1 \\
\hline Water table & None observed \\
\hline $\begin{array}{l}\text { Caliche thickness } \\
\text { (feet) }\end{array}$ & 1 \\
\hline $\begin{array}{l}\text { Maximum carbonate } \\
\text { stage }\end{array}$ & III \\
\hline $\begin{array}{l}\text { Maximum clast } \\
\text { weathering }\end{array}$ & 4 \\
\hline \multicolumn{2}{|l|}{ Lithologies (pct) } \\
\hline Granite-gneiss & 32 \\
\hline $\begin{array}{l}\text { Mafic plutonic- } \\
\text { metamorphic }\end{array}$ & 6 \\
\hline Quartzite & 26 \\
\hline Vein quartz & - \\
\hline Sandstone & 13 \\
\hline Limestone & 1 \\
\hline Chert & Trace \\
\hline Volcanics & 22 \\
\hline Total & 100 \\
\hline
\end{tabular}

\begin{tabular}{|c|c|}
\hline \multicolumn{2}{|c|}{ ENGINEERING TESTS } \\
\hline Sample number & $\# 1$ \\
\hline $\begin{array}{l}\text { Maximum clast size } \\
\text { (inches) }\end{array}$ & 8 \\
\hline \multicolumn{2}{|c|}{ Size distribution (percent) } \\
\hline Cobbles & 12 \\
\hline Coarse Gravel & 49 \\
\hline Fine Gravel & 18 \\
\hline Sand & 18.9 \\
\hline Fines & 2.1 \\
\hline Total & 100 \\
\hline LA Value & 26.4 \\
\hline \multicolumn{2}{|l|}{ Soundness (pct) } \\
\hline$\leq 1.5^{\prime \prime}->0.75^{\prime \prime}$ & 0.4 \\
\hline$\leq 0.75^{\prime \prime}->0.375^{\prime \prime}$ & 0.3 \\
\hline$\leq 0.375$ - >\#4 sieve & 0.4 \\
\hline Specific gravity & 2.572 \\
\hline Percent absorption & 1.3 \\
\hline
\end{tabular}

\begin{tabular}{|l|c|}
\hline PRODUCTION CONSTANT & 10 \\
\hline Estimated gravel thickness (feet) & 22,990 \\
\hline Constant - Maximum recoverable product (tons per acre) & 16,228 \\
\hline Constant - Minimum recoverable product (tons per acre) & \\
\hline CONCLUSIONS & \\
\hline Portland cement concrete - May be suitable. Will require crushing and screening and may require \\
washing. Determine susceptibility to alkali-silica reaction. May require use of low-alkali cement or \\
additives. \\
Asphalt concrete - Suitable. Will require crushing and screening. \\
Base - Suitable. Will require crushing and screening. \\
Difficult mining - Large cobbles may require removal with a grizzly screen. \\
\hline
\end{tabular}




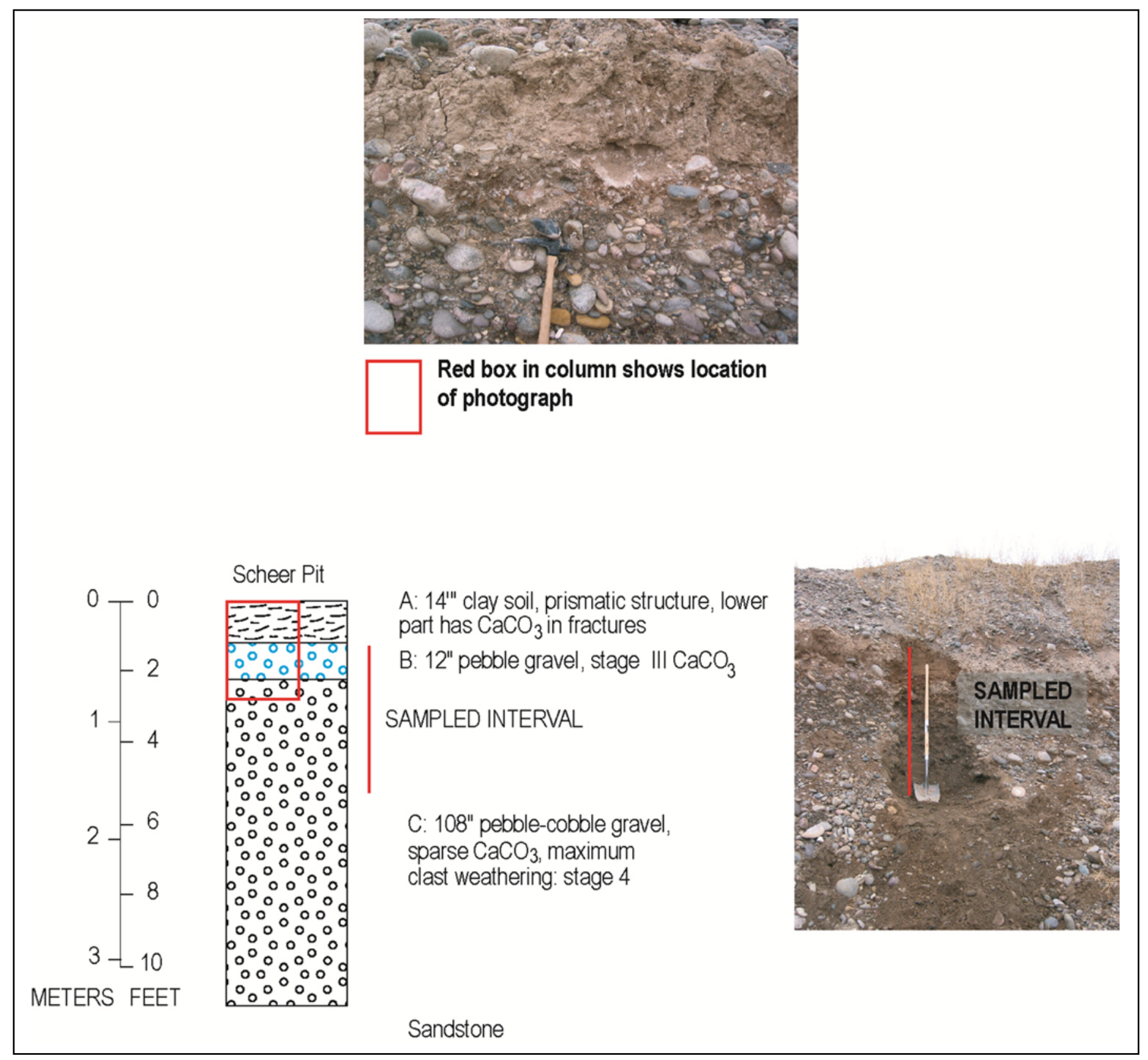




\begin{tabular}{|c|c|c|c|c|c|}
\hline \multicolumn{6}{|c|}{ SCENIC QUALITY FIELD INVENTORY AND EVALUATION CHART } \\
\hline \multicolumn{4}{|c|}{ Panoramic } & & \\
\hline \multicolumn{6}{|c|}{ LANDSCAPE ANALYSIS FACTORS } \\
\hline \multicolumn{6}{|c|}{ Scale of the landscape is expansive. } \\
\hline \multicolumn{6}{|c|}{ LANDSCAPE CHARACTER } \\
\hline & \multicolumn{2}{|c|}{ LANDFORM/WATER } & \multicolumn{2}{|c|}{ VEGETATION } & STRUCTURE \\
\hline FORM & \multicolumn{2}{|c|}{ Simple, strong, flattened. } & \multicolumn{2}{|l|}{ Rounded. } & Vertical, narrow. \\
\hline LINE & \multicolumn{2}{|l|}{ Horizontal. } & \multicolumn{2}{|c|}{ None directional. } & $\begin{array}{l}\text { Angular, vertical (poles), } \\
\text { fence. }\end{array}$ \\
\hline COLOR & \multicolumn{2}{|l|}{ Grey, tan. } & \multicolumn{2}{|c|}{ Grey, green, light yellow. } & Khaki. \\
\hline TEXTURE & \multicolumn{2}{|c|}{$\begin{array}{l}\text { Medium in foreground, fine in } \\
\text { back ground. }\end{array}$} & \multicolumn{2}{|c|}{ Discontinuous. } & Striated. \\
\hline \multicolumn{6}{|c|}{ LANDSCAPE NARRATIVE } \\
\hline \multirow{3}{*}{\multicolumn{6}{|c|}{$\begin{array}{l}\text { The Sheer site (el } 5,600 \mathrm{ft} \text { ) is located approximately } 1.5 \text { mi north of Argo Butte (el } 5,970 \mathrm{ft} \text { ) and the Wind River. It is } \\
\text { adjacent to Mexican Flat. A secondary highway connects the site with U.S. Hwy } 26 \text {. The Sheer site is approximately } \\
56 \text { mi east of Dubois, } 54 \text { mi west of Riverton, and } 58 \text { mi north of Lander. Low cloud cover covered distant views. A } \\
\text { sandstone formation and mountains could be discerned to the west. Foreground and sky occupy much of the } \\
\text { landscape. } \\
\text { Vegetation is sparse, consisting of small sage and grasses, some tumbleweed. The soil appears sandy. } \\
\text { The site appears isolated except for cultural modifications. The Wyoming Canal and Deshaw Ditch are less than 2,000 } \\
\text { ft to the south. There is the intermittent smell of sulfur. Fencing, power lines, pipeline (orange), and oil jacks are } \\
\text { visible in the middleground. The Steamboat Butte Oil Field is less than } 1 \text { mile northwest of the site. The site is well } \\
\text { hidden from vehicular traffic except for } 3 \text { seconds. }\end{array}$}} \\
\hline & & & & & \\
\hline & & & & & \\
\hline \multicolumn{6}{|c|}{ SCENIC QUALITY RATING } \\
\hline & & \multicolumn{4}{|c|}{ SCORE } \\
\hline \multicolumn{2}{|c|}{ LANDFORM } & 5 & 3 & 1 & \\
\hline \multicolumn{2}{|c|}{ VEGETATION } & 5 & 3 & 1 & 2 \\
\hline \multicolumn{2}{|l|}{ WATER } & 5 & 3 & 0 & \\
\hline \multicolumn{2}{|l|}{ COLOR } & 5 & 3 & 1 & \\
\hline \multicolumn{2}{|c|}{ ADJACENT SCENERY } & 5 & 3 & 0 & 1 \\
\hline \multicolumn{2}{|c|}{ SCARCITY } & 5 & 3 & 1 & 1 \\
\hline \multicolumn{2}{|c|}{ CULTURAL MODIFICATIONS } & 2 & 0 & -4 & \\
\hline \multicolumn{2}{|c|}{ TOTAL SCORE } & & & & \\
\hline $\begin{array}{l}\text { SCENIC QI } \\
\text { CLASSIFIC }\end{array}$ & $\begin{array}{l}\text { ALITY } \\
\text { ITION }\end{array}$ & C & & & \\
\hline
\end{tabular}



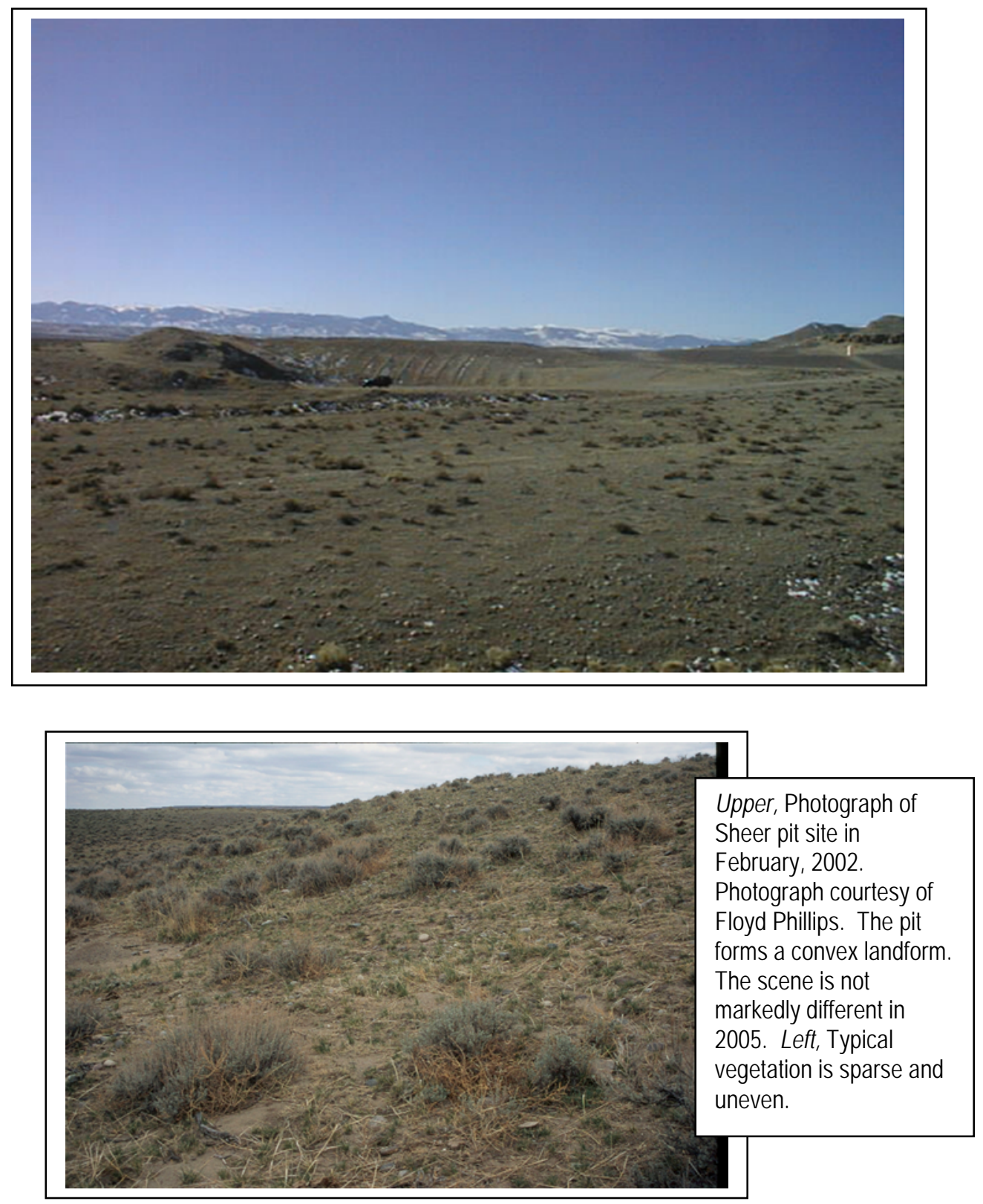
This page intentionally left blank.

A-71 


\section{Site Name: Willow Creek}

Location: SW 1/4, SW 1/4, S20, T4N, R3W, Wind River Meridian USGS Topographic Sheet: Crowheart

Date: 21 April 2005

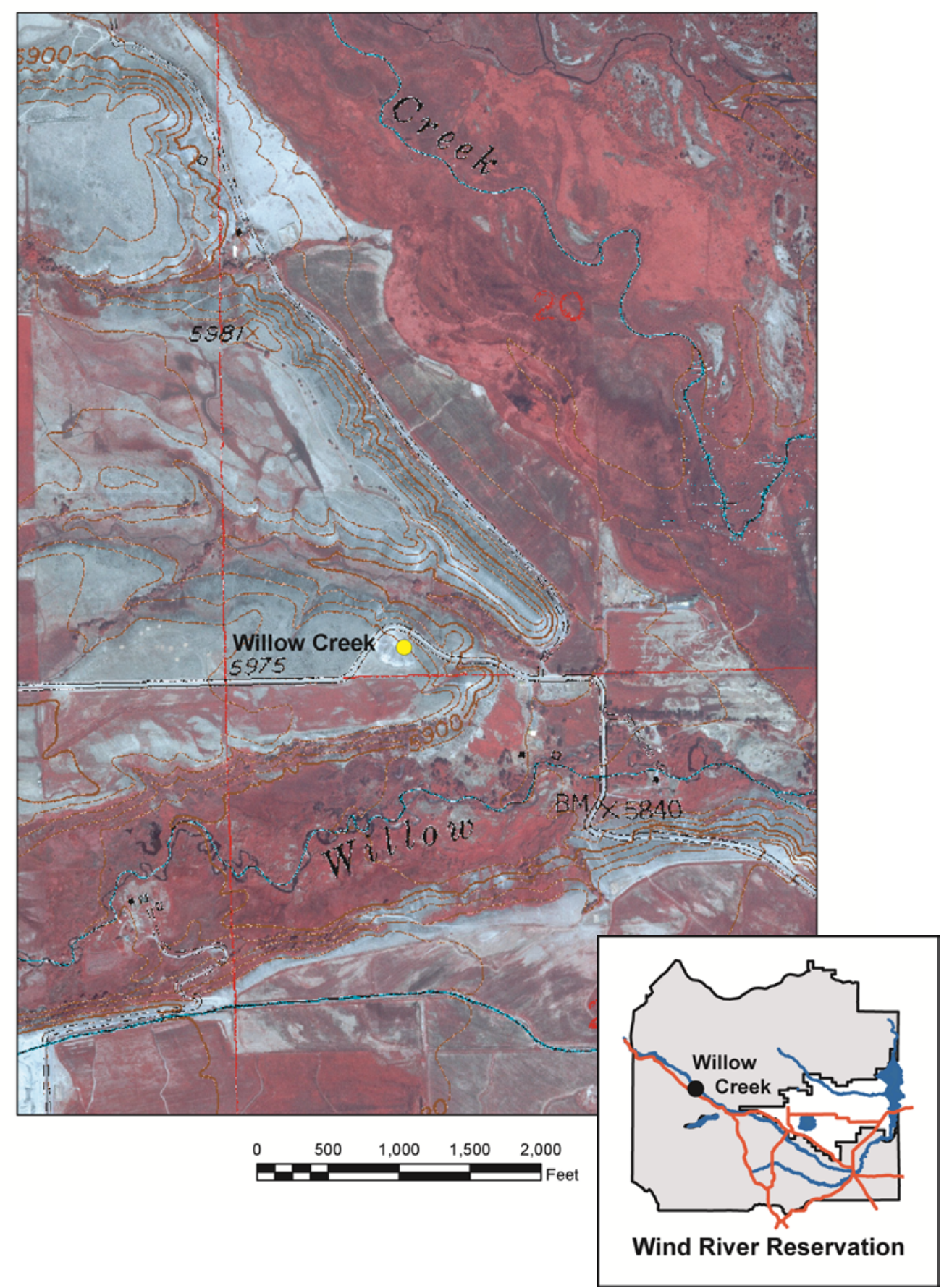


WILLOW CREEK: Sheet 2 of 5

\begin{tabular}{|c|c|}
\hline \multicolumn{2}{|c|}{ GEOLOGIC DESCRIPTION } \\
\hline Sample number & $\# 1$ \\
\hline Location & $\begin{array}{c}43^{\circ} 18^{\prime} 06.7^{\prime \prime} \\
109^{\circ} 08^{\prime} 42.7^{\prime \prime} \\
\end{array}$ \\
\hline Terrace level Qt & 5 \\
\hline Gravel thickness (feet) & 15 \\
\hline $\begin{array}{l}\text { Overburden thickness } \\
\text { (feet) }\end{array}$ & 2 \\
\hline Water table & None observed \\
\hline $\begin{array}{l}\text { Caliche thickness } \\
\text { (feet) }\end{array}$ & $6-7$ \\
\hline $\begin{array}{l}\text { Maximum carbonate } \\
\text { stage }\end{array}$ & III \\
\hline $\begin{array}{l}\text { Maximum clast } \\
\text { weathering }\end{array}$ & 4 \\
\hline \multicolumn{2}{|l|}{ Lithologies (pct) } \\
\hline Granite-gneiss & 18 \\
\hline $\begin{array}{l}\text { Mafic plutonic- } \\
\text { metamorphic }\end{array}$ & 9 \\
\hline Quartzite & 26 \\
\hline Vein quartz & - \\
\hline Sandstone & 33 \\
\hline Limestone & 1 \\
\hline Chert & - \\
\hline Volcanics & 13 \\
\hline Total & 100 \\
\hline
\end{tabular}

\begin{tabular}{|c|c|}
\hline \multicolumn{2}{|c|}{ ENGINEERING TESTS } \\
\hline Sample number & $\# 1$ \\
\hline $\begin{array}{l}\text { Maximum clast size } \\
\text { (inches) }\end{array}$ & 14 \\
\hline \multicolumn{2}{|c|}{ Size distribution (percent) } \\
\hline Cobbles & 39 \\
\hline Coarse Gravel & 39 \\
\hline Fine Gravel & 12 \\
\hline Sand & 9 \\
\hline Fines & 1 \\
\hline Total & 100 \\
\hline LA Value & 26.8 \\
\hline \multicolumn{2}{|l|}{ Soundness (pct) } \\
\hline$\leq 1.5^{\prime \prime}->0.75^{\prime \prime}$ & 1.4 \\
\hline$\leq 0.75^{\prime \prime}->0.375^{\prime \prime}$ & 1.1 \\
\hline$\leq 0.375$ - $>\# 4$ sieve & 0.4 \\
\hline Specific gravity & 2.559 \\
\hline Percent absorption & 2.1 \\
\hline
\end{tabular}

\begin{tabular}{|l|c|}
\hline PRODUCTION CONSTANT & 15 \\
\hline Estimated gravel thickness (feet) & 34,485 \\
\hline Constant - Maximum recoverable product (tons per acre) & 16,873 \\
\hline Constant - Minimum recoverable product (tons per acre) & \\
\hline CONCLUSIONS & \\
\hline Portland cement concrete - May be suitable. Will require crushing and screening and may require \\
washing. Determine susceptibility to alkali-silica reaction. May require use of low-alkali cement or \\
additives. \\
Asphalt concrete - Suitable. Will require crushing and screening. \\
Base - Suitable. Will require crushing and screening. \\
Deleterious Material - Large amount of calcium carbonate (caliche) coating. Crushing will reduce \\
extent of coating. \\
Difficult mining - Large boulders and large amount of cobbles may complicate mining. Oversized \\
material may have to be removed with a grizzly screen. \\
\hline
\end{tabular}




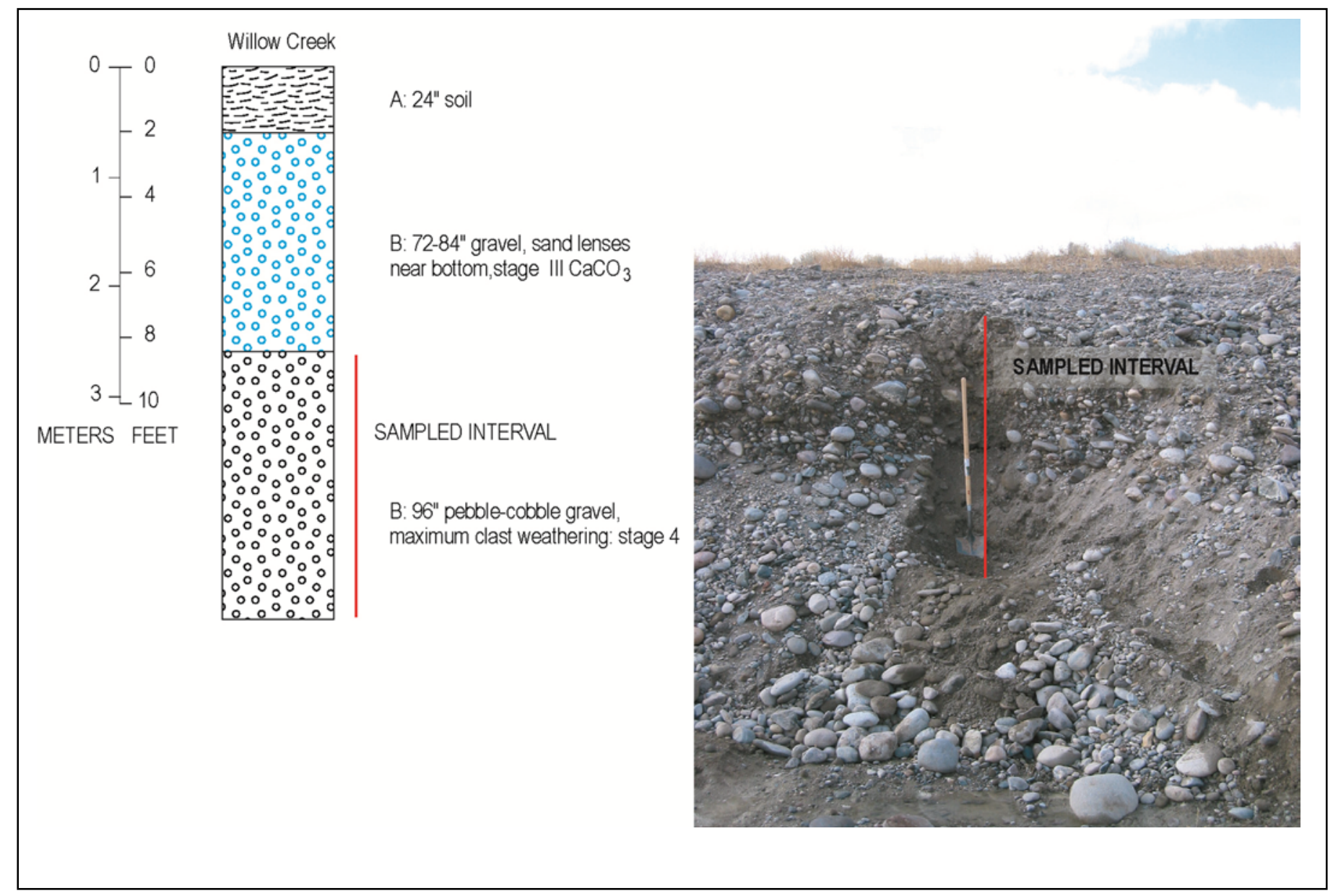


WILLOW CREEK: Sheet 4 of 5

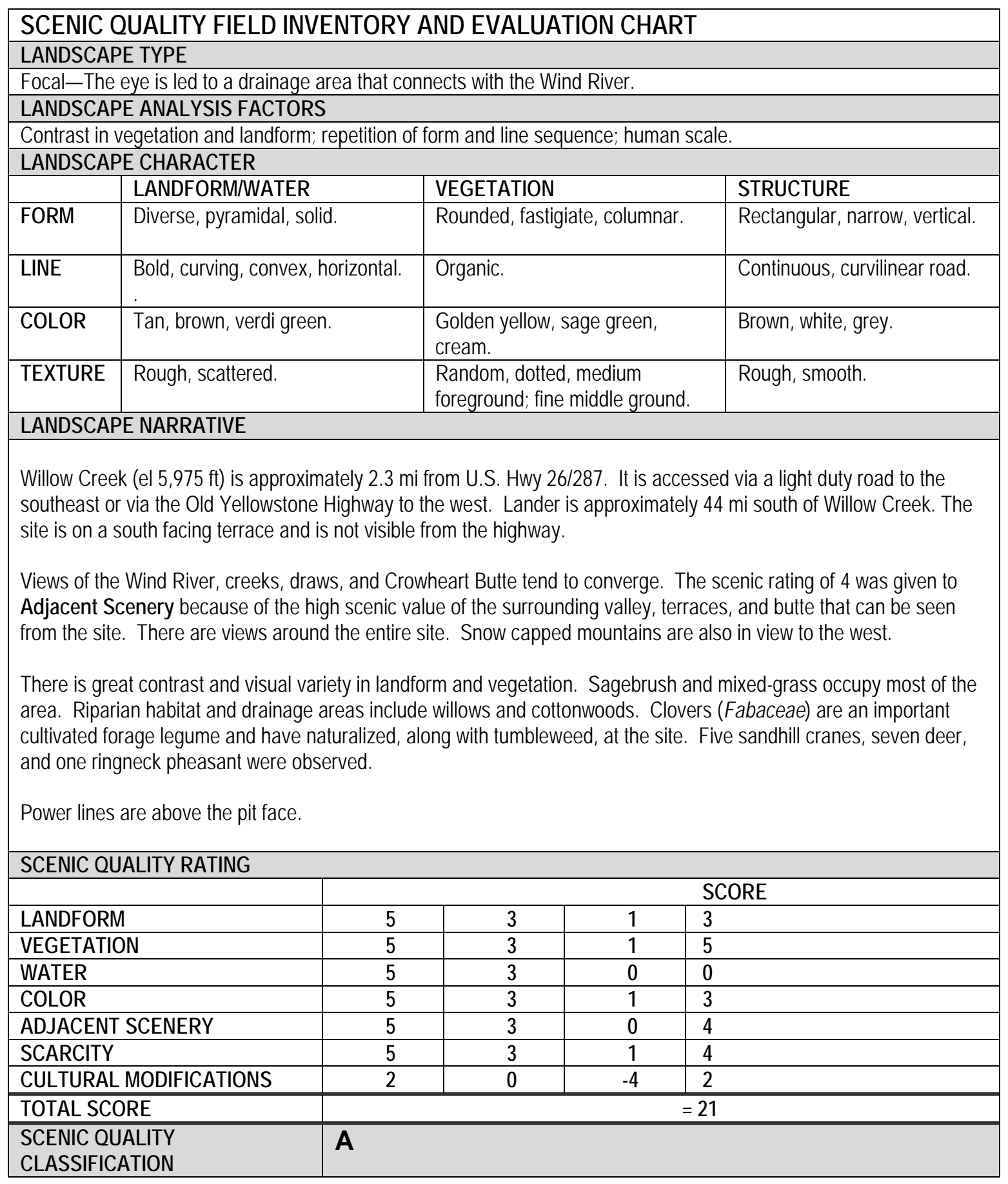


WILLOW CREEK: Sheet 5 of 5
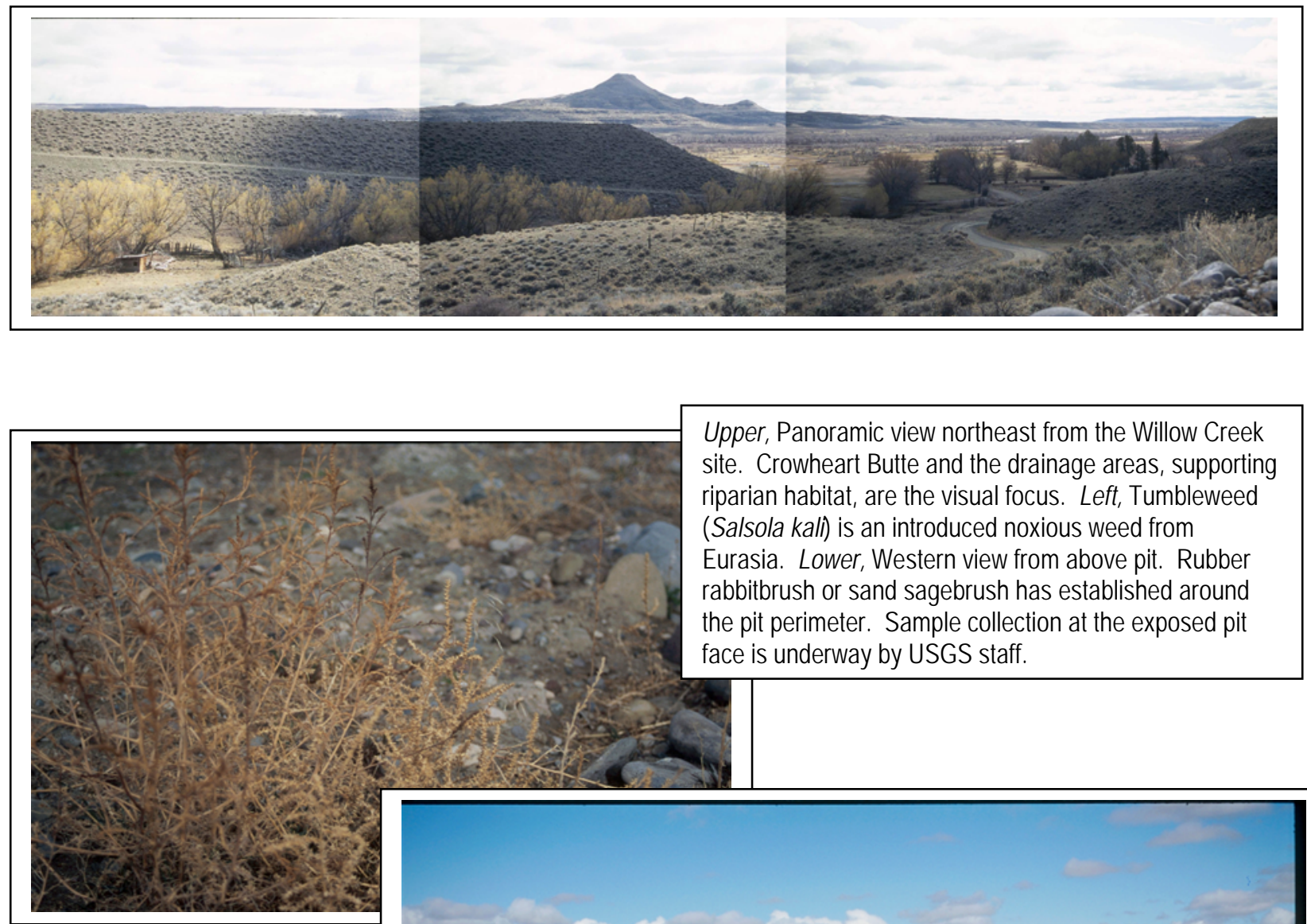

Upper, Panoramic view northeast from the Willow Creek site. Crowheart Butte and the drainage areas, supporting riparian habitat, are the visual focus. Left, Tumbleweed (Salsola kali) is an introduced noxious weed from Eurasia. Lower, Western view from above pit. Rubber rabbitbrush or sand sagebrush has established around the pit perimeter. Sample collection at the exposed pit face is underway by USGS staff.

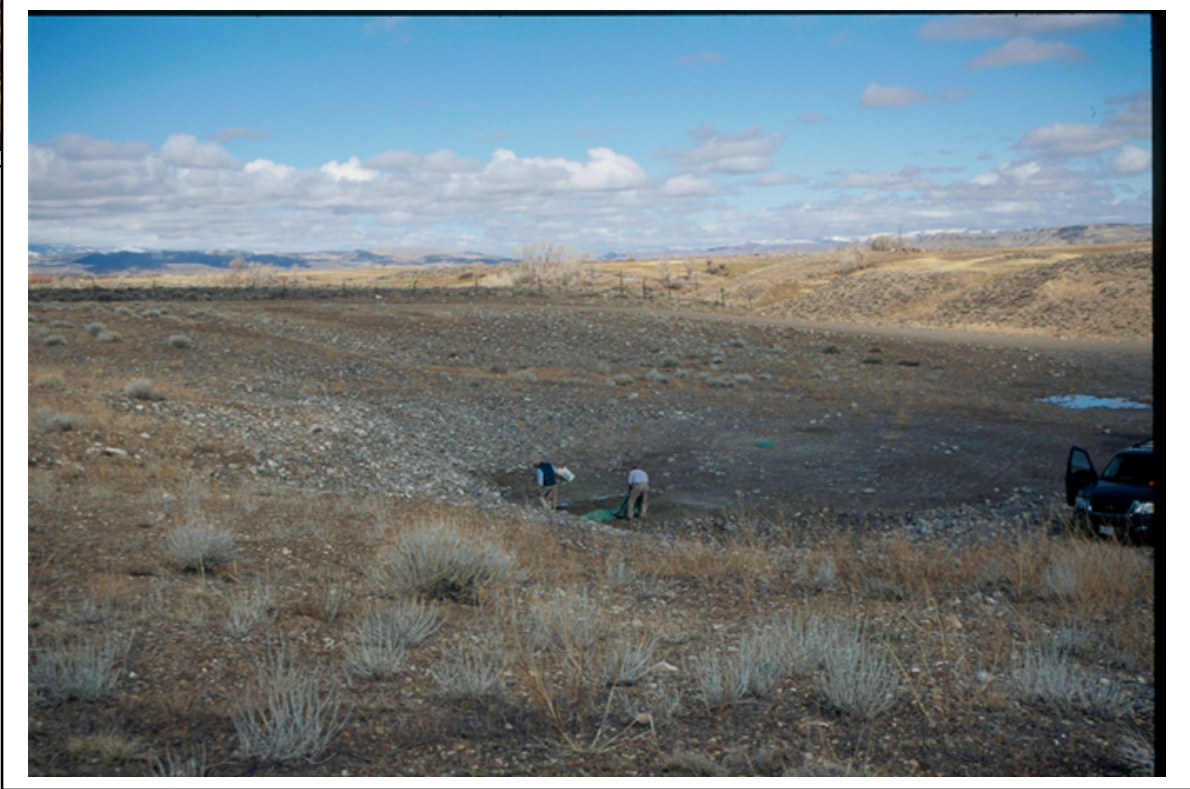


This page intentionally left blank. 


\section{Winkleman Dome \#1 and \#2}

Section 13, T2N, R2W, Wind River Meridian USGS Topographic Sheet: Argo Butte Date: 21 April 2005

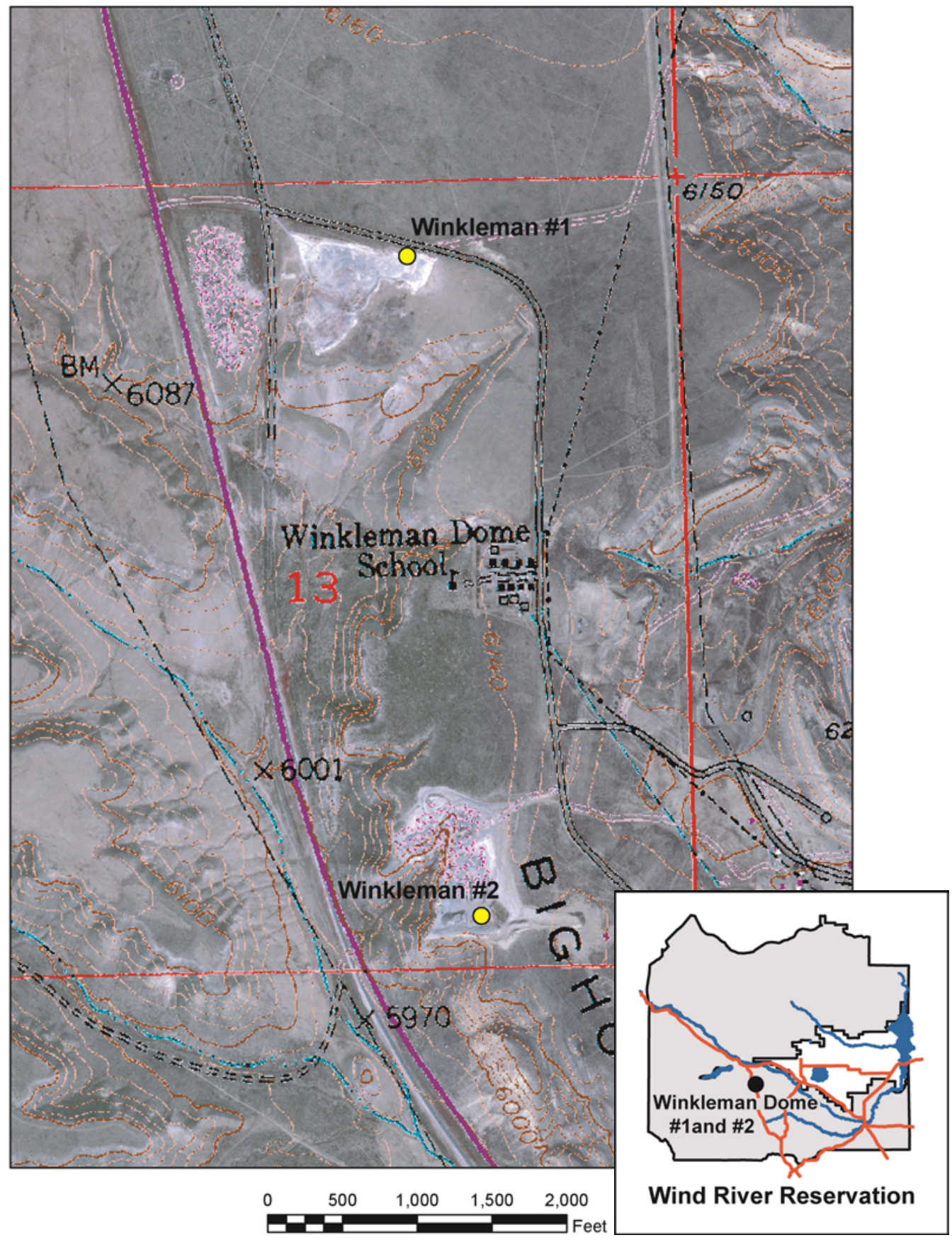




\begin{tabular}{|c|c|c|c|c|c|}
\hline \multicolumn{6}{|c|}{ GEOLOGIC OBSERVATIONS } \\
\hline Investigator & \multicolumn{3}{|c|}{ USGS } & WRMT* & \multirow{2}{*}{$\begin{array}{l}\text { General site } \\
\text { characteristics }\end{array}$} \\
\hline Sample number & $\begin{array}{c}\text { Winkleman Dome } \\
\# 1 \\
\text { Sample \#1 }\end{array}$ & $\begin{array}{c}\text { Winkleman Dome } \\
\# 2 \\
\text { Sample \#1 }\end{array}$ & $\begin{array}{c}\text { Winkleman Dome } \\
\text { \#2 } \\
\text { Stockpile Sample }\end{array}$ & $\begin{array}{l}\text { Average } 6 \\
\text { samples }\end{array}$ & \\
\hline Location & $\begin{array}{l}43^{\circ} 09^{\prime} 16.2^{\prime \prime} \\
108^{\circ} 56^{\prime} 19.1^{\prime \prime}\end{array}$ & $\begin{array}{l}43^{\circ} 08^{\prime} 32.6^{\prime \prime} \\
108^{\circ} 56^{\prime} 13.9^{\prime \prime} \\
\end{array}$ & - & - & - \\
\hline Terrace level Qt & 11 & 11 & - & - & 11 \\
\hline $\begin{array}{l}\text { Gravel thickness } \\
\text { (feet) }\end{array}$ & 9 & 9 & - & - & 9 \\
\hline $\begin{array}{l}\text { Overburden } \\
\text { thickness (feet) }\end{array}$ & 1 & 1 & - & - & 1 \\
\hline $\begin{array}{l}\text { Caliche thickness } \\
\text { (feet) }\end{array}$ & 7 & 5 & - & - & 6 \\
\hline $\begin{array}{l}\text { Maximum } \\
\text { carbonate stage }\end{array}$ & III & III & - & - & III \\
\hline $\begin{array}{l}\text { Maximum clast } \\
\text { weathering }\end{array}$ & 4 & 4 & - & - & 4 \\
\hline \multicolumn{6}{|l|}{ Lithologies (pct) } \\
\hline Granite-gneiss & 18 & 18 & - & - & 18 \\
\hline $\begin{array}{l}\text { Mafic plutonic- } \\
\text { metamorphic }\end{array}$ & 8 & 5 & - & - & 6.5 \\
\hline Quartzite & 20 & 8 & - & - & 14 \\
\hline Vein quartz & 1 & 2 & - & - & 1.5 \\
\hline Sandstone & 2 & 4 & - & - & 3 \\
\hline Limestone & - & - & - & - & - \\
\hline Chert & Trace & 1 & - & - & 0.5 \\
\hline Volcanics & 51 & 62 & - & - & 56.5 \\
\hline Total & 100 & 100 & - & - & 100 \\
\hline
\end{tabular}

* Wind River Materials Testing, 2004 


\begin{tabular}{|c|c|c|c|c|c|}
\hline \multicolumn{6}{|c|}{ ENGINEERING TESTS } \\
\hline Investigator & \multicolumn{3}{|c|}{ USGS } & \multirow{2}{*}{$\begin{array}{l}\text { WRMT }^{\star 1} \\
\text { Average } 6 \\
\text { samples }\end{array}$} & \multirow[b]{2}{*}{$\begin{array}{c}\text { General Site } \\
\text { Characteristics } \\
\text { Excluding Stockpile }\end{array}$} \\
\hline Sample number & $\begin{array}{l}\text { Winkleman } \\
\text { Dome \#1 } \\
\text { Sample \#1 }\end{array}$ & $\begin{array}{l}\text { Winkleman } \\
\text { Dome \#2 } \\
\text { Sample \#1 }\end{array}$ & $\begin{array}{c}\text { Winkleman } \\
\text { Dome \#2 } \\
\text { Stockpile } \\
\text { Sample } \\
\end{array}$ & & \\
\hline \multicolumn{6}{|l|}{ Grain Size Analysis } \\
\hline $\begin{array}{l}\text { Maximum clast size } \\
\text { (inches) }\end{array}$ & 10 & Cobble & - & - & 10 \\
\hline \multicolumn{6}{|c|}{ Size distribution (percent) } \\
\hline Cobbles & 27 & 6 & 0 & 25.9 & 22.8 \\
\hline Coarse Gravel & 39 & 43 & 15 & 31.6 & 34.0 \\
\hline Fine Gravel & 16 & 19 & 41 & 14.4 & 15.2 \\
\hline Sand & 17 & 30.4 & 35.4 & 25.5 & 25.0 \\
\hline Fines & 1.0 & 1.6 & 8.6 & 2.7 & 2.4 \\
\hline Total & 100 & 100 & 100 & $100.1 * 2$ & $99.4^{\star 2}$ \\
\hline LA Value & 23.6 & 24.8 & 28.2 & - & 24.2 \\
\hline \multicolumn{6}{|l|}{ Soundness } \\
\hline$\leq 1.5^{\prime \prime}->0.75^{\prime \prime}$ & 0.4 & 0.2 & & - & 0.3 \\
\hline$\leq 0.75^{\prime \prime}->0.375^{\prime \prime}$ & 0.4 & 0.6 & 0.9 & - & 0.5 \\
\hline$\leq 0.375->\# 4$ sieve & 0.5 & 0.5 & 0.7 & - & 0.5 \\
\hline Specific gravity & 2.553 & 2.525 & 2.540 & - & 2.539 \\
\hline Percent absorption & 1.7 & 1.9 & 1.7 & - & 1.8 \\
\hline
\end{tabular}

*1 Wind River Materials Testing, 2004

*2 Numbers do not add to 100 due to rounding

\section{PRODUCTION CONSTANT}

Estimated gravel thickness (feet)

Constant - Maximum recoverable product

Constant - Minimum recoverable product

CONCLUSIONS

Portland cement concrete - May be suitable. Will require crushing and screening and may require washing. Large amount of volcanics indicate likelihood for alkali-silica reaction. Determine susceptibility to alkali-silica reaction. May require use of low-alkali cement or additives.

Asphalt concrete - Suitable. Will require crushing and screening.

Base - Suitable. Will require crushing and screening.

Specific gravity - May be marginally acceptable.

Deleterious Material - Large amount of calcium carbonate (caliche) coating. Crushing will reduce extent of coating.

Difficult mining - Large boulders and large amount of cobbles may complicate mining. Oversized material may have to be removed with a grizzly screen. 
Winkleman Dome \#1

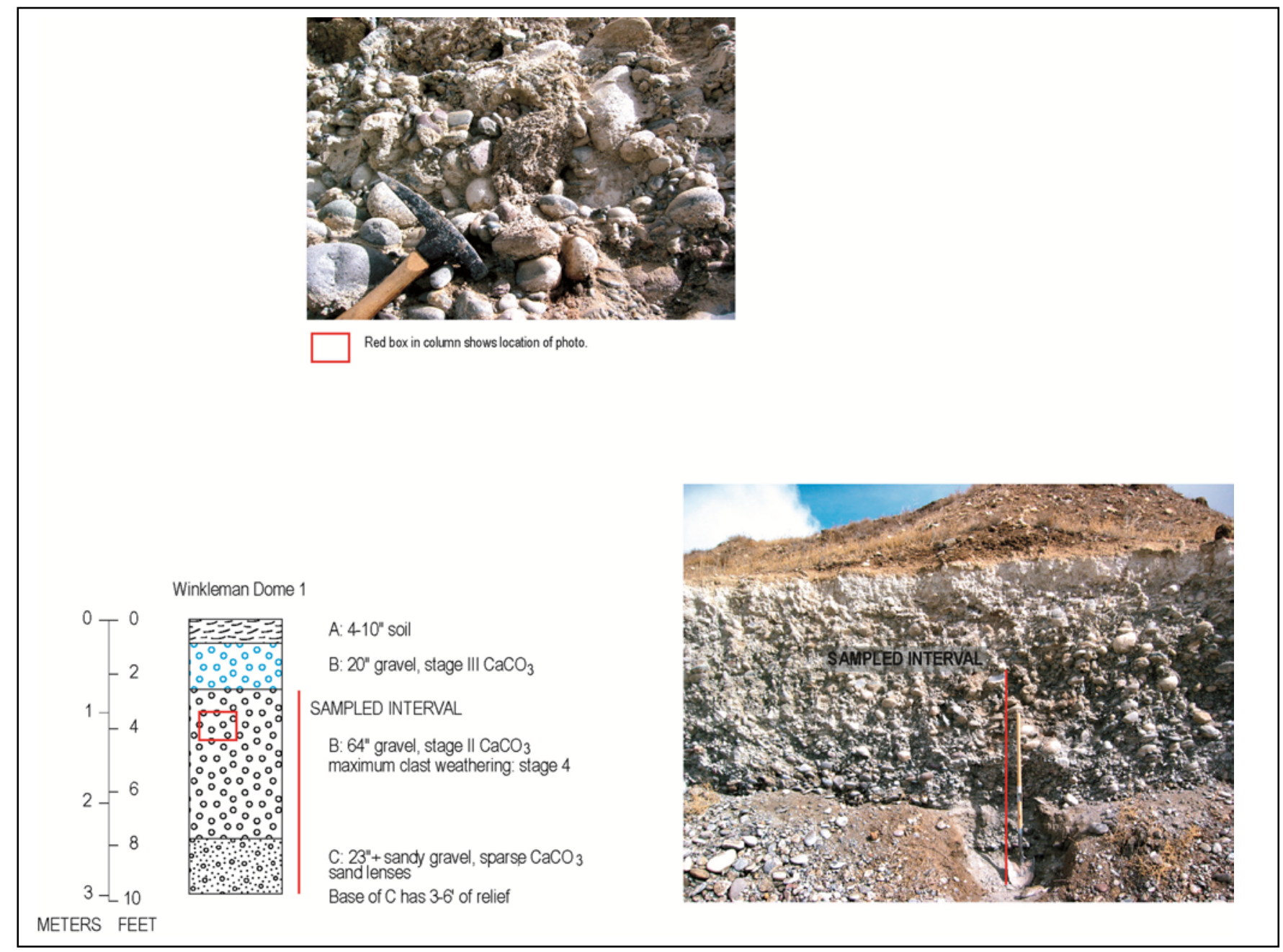

Winkleman Dome \#2

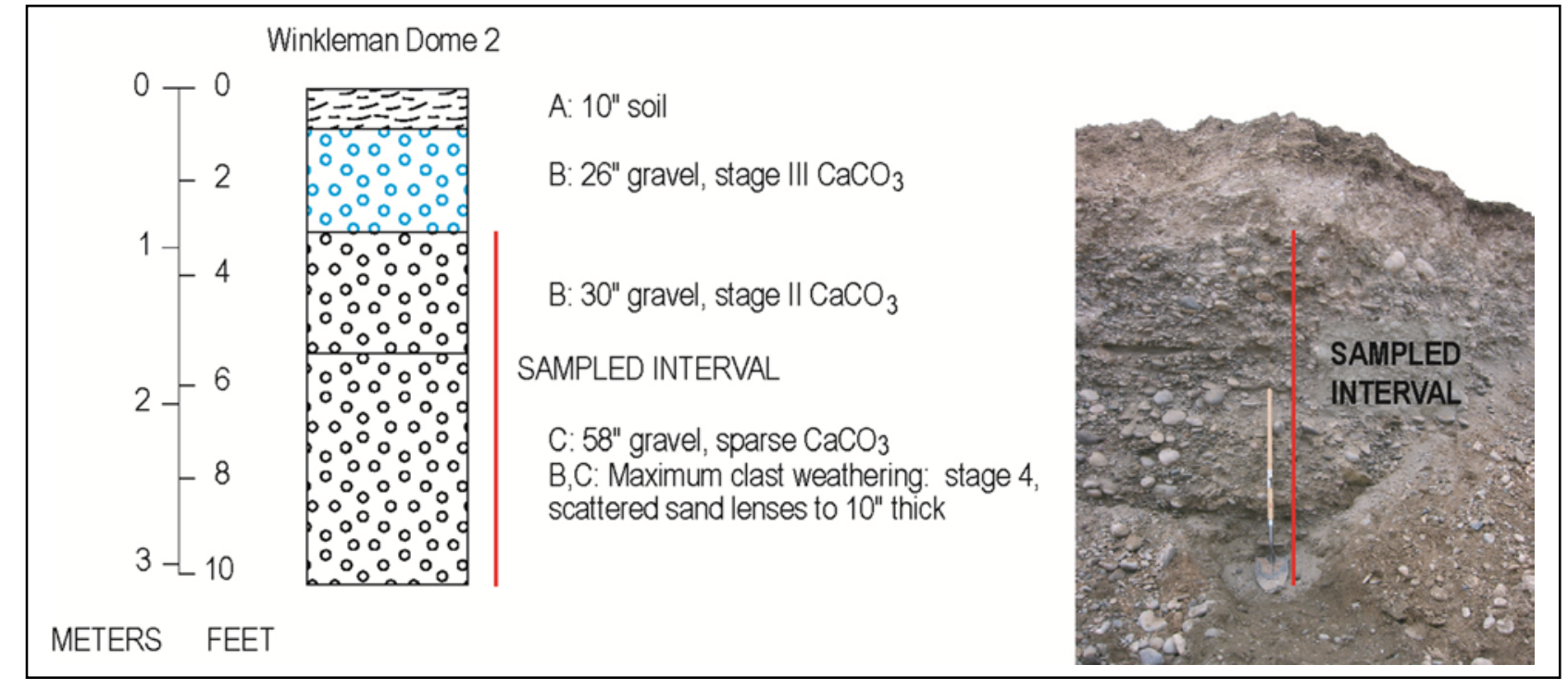


WINKLEMAN DOME: Sheet 5 of 10

This page intentionally left blank. 
Winkleman Dome \#1

\begin{tabular}{|c|c|c|c|}
\hline \multirow{2}{*}{\multicolumn{4}{|c|}{ SCENIC QUALITY FIELD INVENTORY AND EVALUATION CHART }} \\
\hline \multirow{2}{*}{\multicolumn{4}{|c|}{$\begin{array}{l}\text { LANDSCAPE TYPE } \\
\text { Panoramic }\end{array}$}} \\
\hline & & & \\
\hline \multicolumn{4}{|c|}{ LANDSCAPE ANALYSIS FACTORS } \\
\hline \multicolumn{4}{|c|}{ Scale-Mountains fill the background, the foreground and middle ground appear unified. } \\
\hline \multicolumn{4}{|c|}{ LANDSCAPE CHARACTER } \\
\hline & LANDFORM/WATER & VEGETATION & STRUCTURE \\
\hline FORM & $\begin{array}{l}\text { Relatively flat foreground, } \\
\text { concave middle ground. }\end{array}$ & $\begin{array}{l}\text { Simple, low (limited to grasses } \\
\text { and tiny cushion forbs. }\end{array}$ & $\begin{array}{l}\text { Rectangular (single } \\
\text { residence). }\end{array}$ \\
\hline LINE & Bold, angular, diagonal. & Soft, continuous. & Vertical (telephone poles). \\
\hline COLOR & White (seasonal), shades of grey. & Tan and light green, monotone. & White. \\
\hline TEXTURE & Medium in foreground. & Uniform and smooth throughout. & Discontinuous. \\
\hline
\end{tabular}

The Winkleman Dome \#1 site (el 6,160 ft) is located south of Bighorn Flat, approximately 0.4 mi from U.S. Hwy 287. Lander is approximately 26 mi south. Access and linear views are along a dirt road, frequented mainly by trucks. Oil and gas development, Winkleman Dome oil field, is less than 1 mile away to the south. Spoils are visible around the entire active sand and gravel pit. There is little visual variety in the landscape.

The scenic rating of 4 was given to Adjacent Scenery because of the high scenic value of the surrounding Wind River Mountains that can be seen from the site. There are uninterrupted views around the entire site.

Most of the foreground and middle ground views are of uniformly colored and textured mixed grass; there is little contrast or variety.

\begin{tabular}{|c|c|c|c|c|}
\hline \multicolumn{5}{|l|}{ SCENIC QUALITY RATING } \\
\hline & \multicolumn{4}{|r|}{ SCORE } \\
\hline LANDFORM & 5 & 3 & 1 & 1 \\
\hline VEGETATION & 5 & 3 & 1 & 1 \\
\hline WATER & 5 & 3 & 0 & 0 \\
\hline COLOR & 5 & 3 & 1 & 1 \\
\hline ADJACENT SCENERY & 5 & 3 & 0 & 4 \\
\hline SCARCITY & 5 & 3 & 1 & 2 \\
\hline CULTURAL MODIFICATIONS & 2 & 0 & -4 & -2 \\
\hline TOTAL SCORE & \multicolumn{4}{|c|}{$=8$} \\
\hline $\begin{array}{l}\text { SCENIC QUALITY } \\
\text { CLASSIFICATION }\end{array}$ & C & & & \\
\hline
\end{tabular}

WINKLEMAN DOME: Sheet 6 of 9 

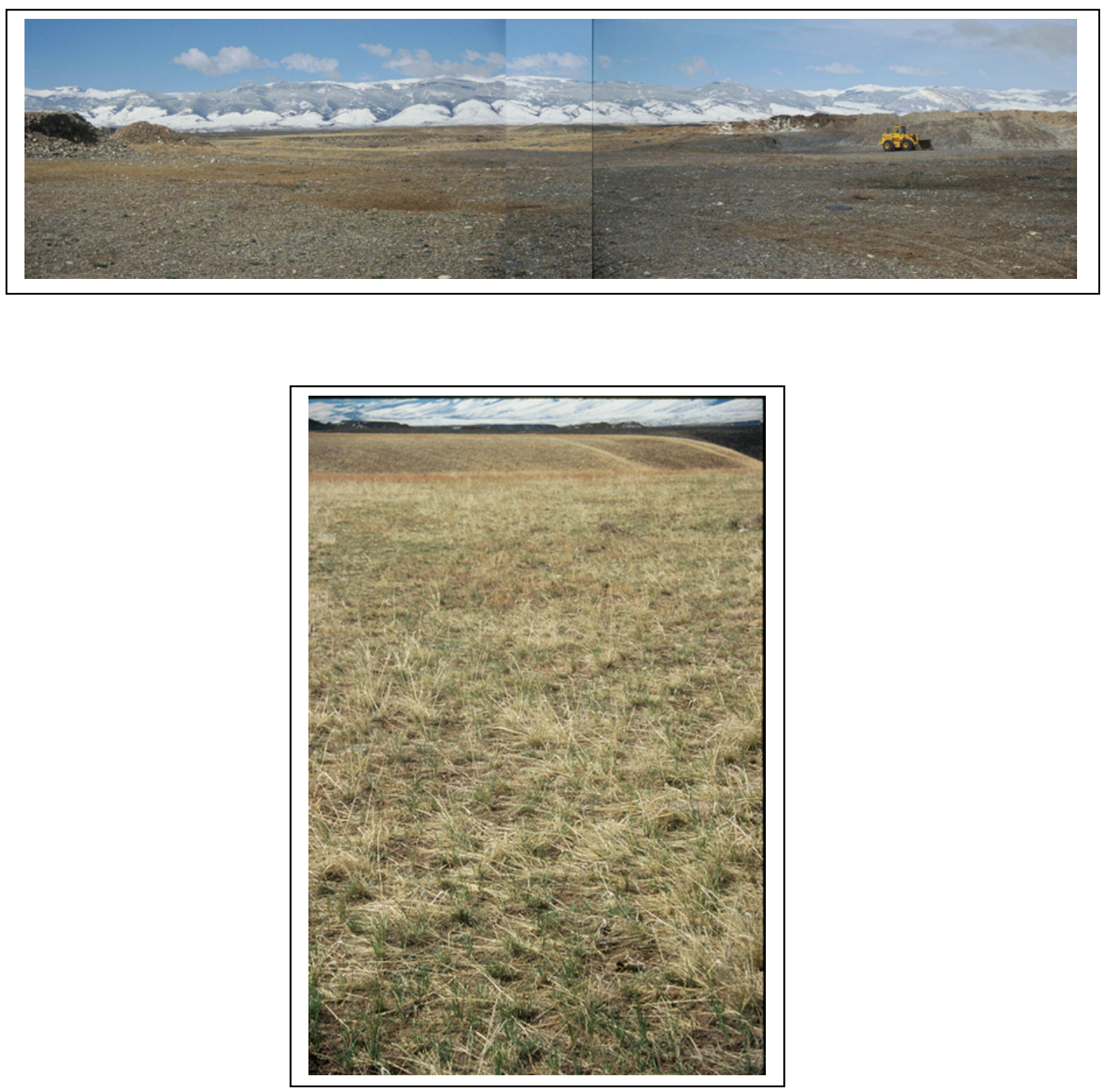

Upper, the Winkleman Dome \#1 site has little sense of boundary except for the Wind River Mountains to the west. The photograph was taken with a $50 \mathrm{~mm}$ lens in order to represent the cone of vision and depth of field an observer would experience on site. The photographs were joined together in Adobe Photoshop. Lower, Typical mixed grass vegetation and terrace slopes in the area. 
WINKLEMAN DOME: Sheet 8 of 10

\section{Winkleman Dome \#2}

\begin{tabular}{|c|c|c|c|}
\hline \multicolumn{4}{|c|}{ SCENIC QUALITY FIELD INVENTORY AND EVALUATION CHART } \\
\hline \multicolumn{4}{|c|}{$\begin{array}{l}\text { LANDSCAPE TYPE } \\
\text { Panoramic }\end{array}$} \\
\hline \multicolumn{4}{|c|}{ LANDSCAPE ANALYSIS FACTORS } \\
\hline \multicolumn{4}{|c|}{ High contrast between landform and vegetative patterns. Line sequence of telephone poles. } \\
\hline \multicolumn{4}{|c|}{ LANDSCAPE CHARACTER } \\
\hline & LANDFORM/WATER & VEGETATION & STRUCTURE \\
\hline FORM & $\begin{array}{l}\text { Flat top terraces; ovals (exposed } \\
\text { sedimentary rocks along terrace } \\
\text { face). }\end{array}$ & Spreading, rounded. & Vertical, rectangular. \\
\hline LINE & Flowing and interrupted horizontal. & Undulating. & Simple, regular. \\
\hline COLOR & Light orange, tan, white (seasonal). & Grey, green. & Black, brown, beige, white \\
\hline TEXTURE & Small patches, striated. & Medium, stippled, fairly even. & Rough. \\
\hline
\end{tabular}

The Winkleman Dome 2 site (el 6,120 ft) is located along Bighorn Ridge, approximately 3 mi away from U.S. Hwy 28, and $32 \mathrm{mi}$ from Lander to the south. The Shoshone Tribal processing plant is located at this site. Access and linear views are along a dirt road to the east, frequented mainly by trucks. Winkleman Dome oil field is less than $0.3 \mathrm{mi}$ to the east. Oil derricks and the smell of sulfur are noticeable and considered detrimental cultural modifications. Telephone poles are visible along the southwest skyline. An aqueduct (water source) is within $0.2 \mathrm{mi}$ to the east.

Winkleman Dome 2 is visible for $360^{\circ}$ but there are few anticipated observers from the unimproved road. There is a definite foreground, middle ground (two terraces with some exposed sandstone providing contrast) and back ground (mountains). The Owl Creek Mountains are to the northeast and the Wind River Mountains are to the southwest. Low cloud cover may have minimized the drama of the background views.

The vegetation is dominated by Wyoming big sagebrush. The texture of the vegetation appears coarse in the foreground and medium in the middle ground. There is contrast in color between the rock and vegetation in the middle ground.

\begin{tabular}{|l|l|l|l|l|}
\hline SCENIC QUALITY RATING & \multicolumn{5}{|l|}{ SCORE } \\
\hline LANDFORM & 5 & 3 & 1 & 3 \\
\hline VEGETATION & 5 & 3 & 1 & 2 \\
\hline WATER & 5 & 3 & 0 & 0 \\
\hline COLOR & 5 & 3 & 1 & 3 \\
\hline ADJACENT SCENERY & 5 & 3 & 0 & 4 \\
\hline SCARCITY & 5 & 3 & 1 & 3 \\
\hline CULTURAL MODIFICATIONS & 2 & 0 & -4 & -4 \\
\hline \hline TOTAL SCORE & \multicolumn{5}{|l|}{$=11$} \\
\hline \hline SCENIC QUALITY & C \\
CLASSIFICATION & \multicolumn{5}{|l|}{} \\
\hline
\end{tabular}




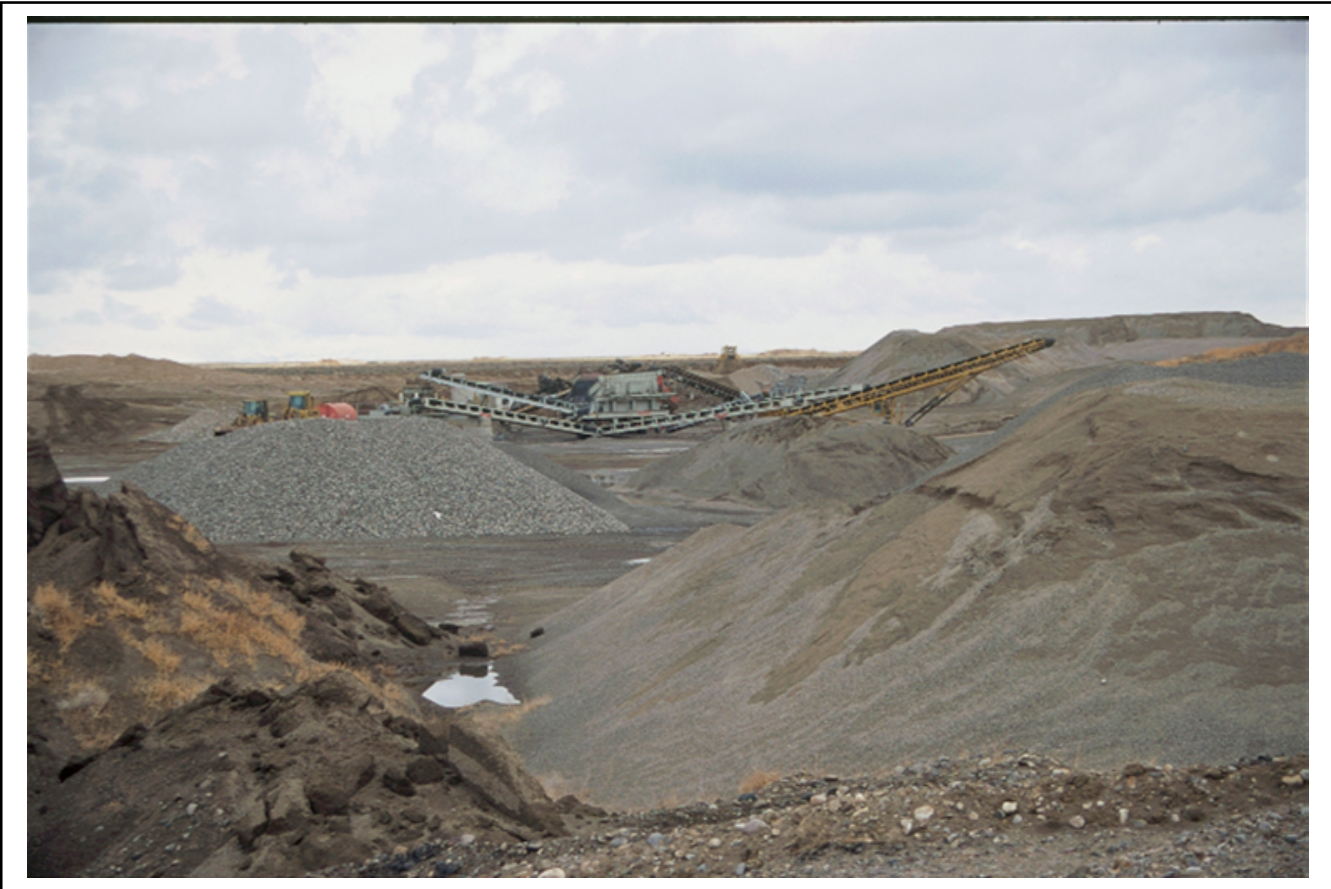

Upper, The Winkleman Dome 2 site includes a Shoshone Tribal processing plant. Stock piles and equipment are evident in this northeast view. Lower, The view southwest is of the typical Wyoming big sagebrush land cover. Photograph was taken from above the pit on the terrace tread. The Wind River Mountains are in the background.

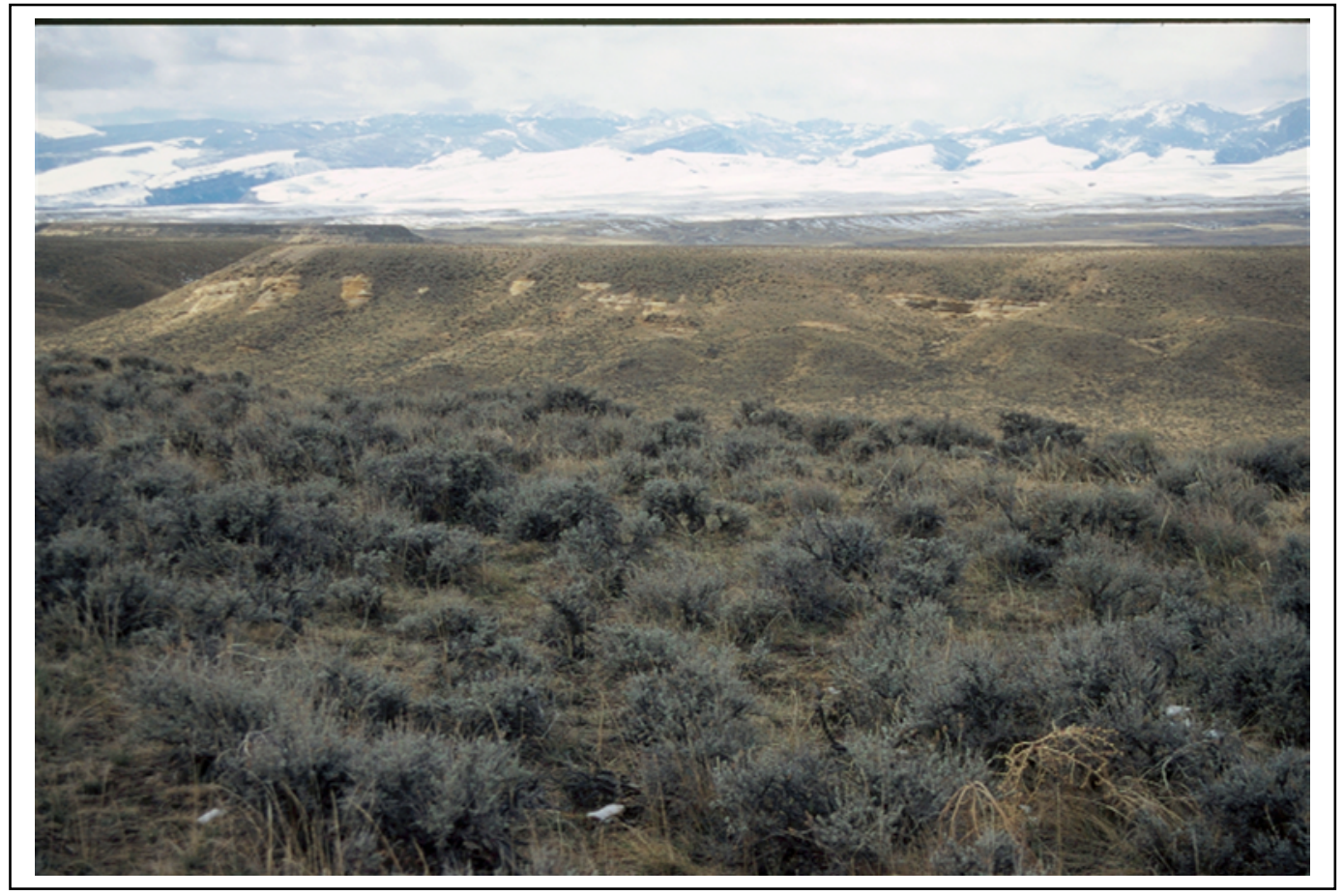




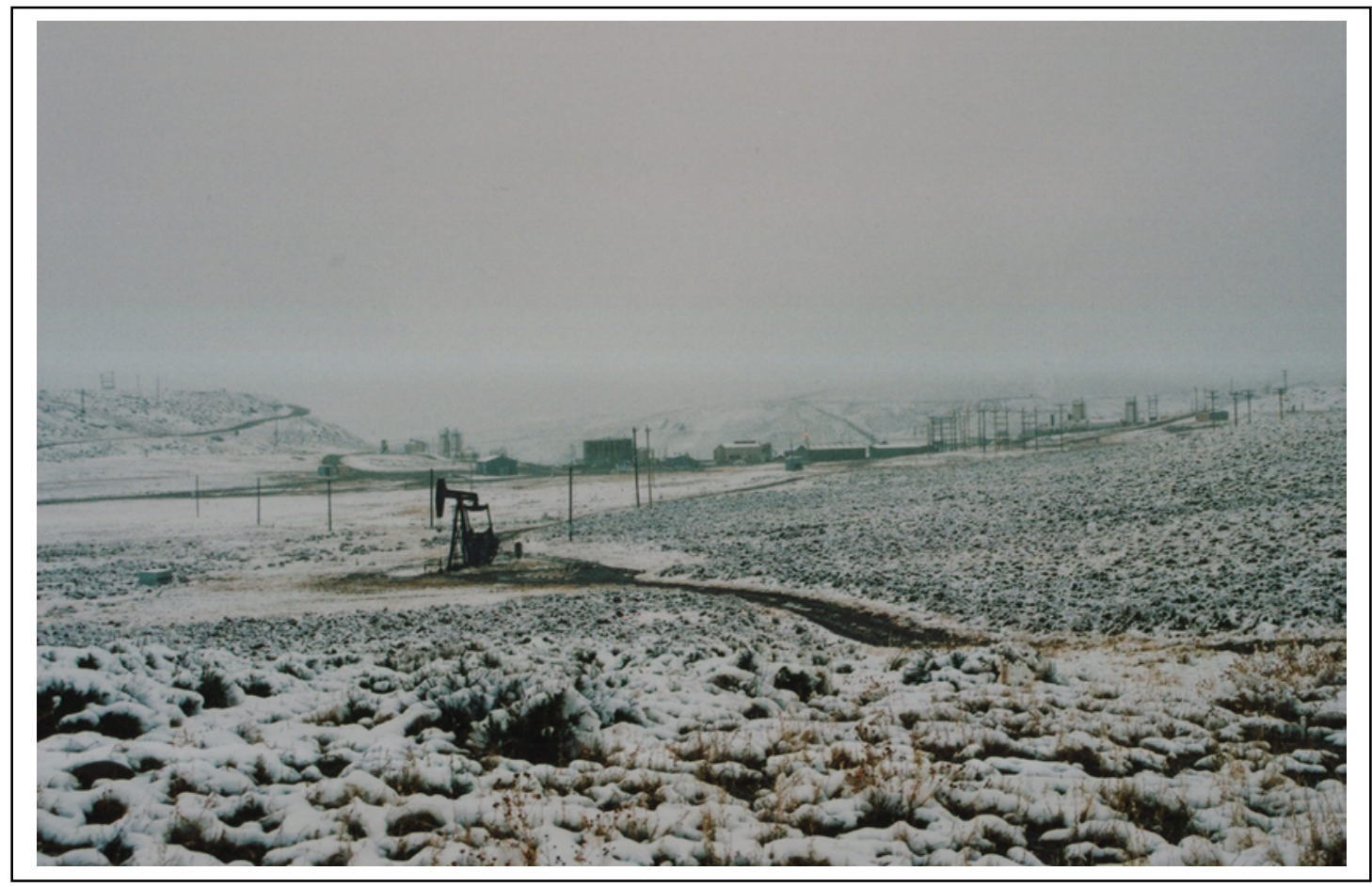

View east. The Winkleman Dome 2 site is adjacent to the Winkleman Dome oil field. Roads, storage tanks, and an oil derrick are noticeable cultural modifications, even during an early spring snowstorm. 
This page intentionally left blank.

A-88 
This page intentionally left blank. 


\section{Appendix B-Photographic Documentation Representing Scenic Quality of Each Site}




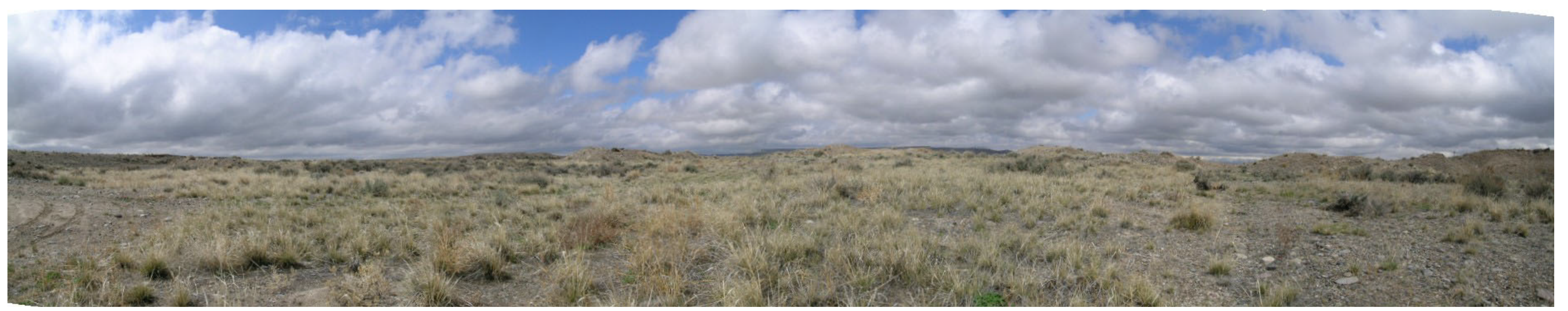

Plate Number 1

Location: AIRPORT HILL

View Direction: Southeast

Date and Time of Day: April 20, 2005 AM

General Description: The snow has melted and the sky is overcast with grey clouds, windy. The surface dries quickly.

The panoramic, relatively flat, grassy terrain is dotted with small spoil heaps. 


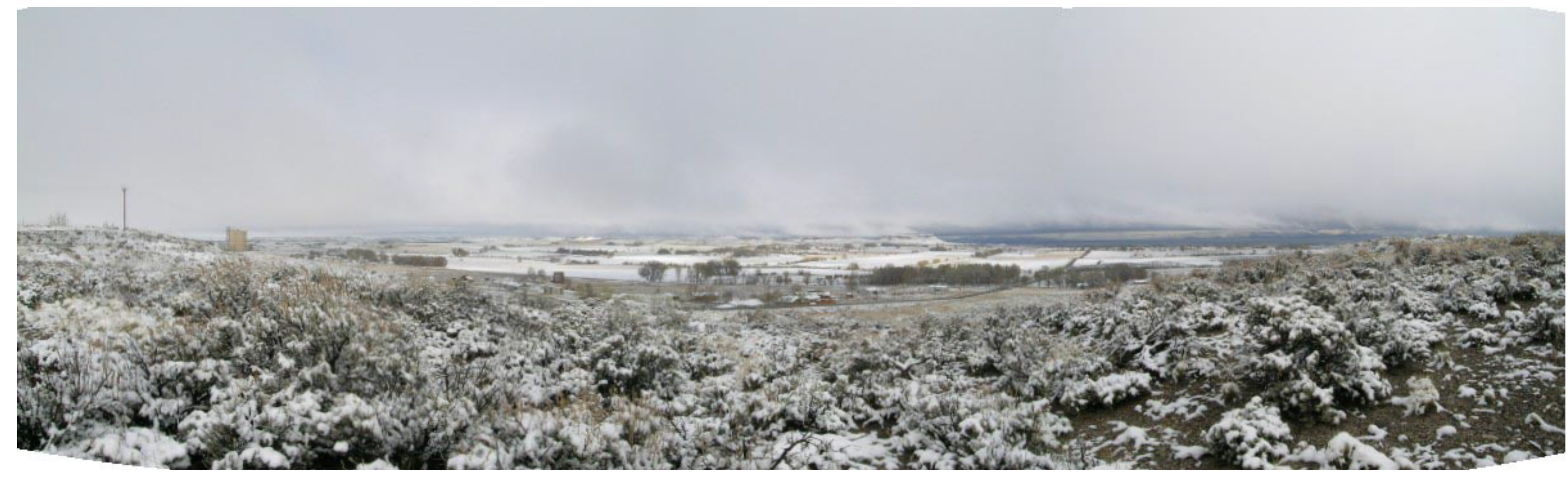

Plate Number 2

Location: BURMA HILL

View Direction: Northwest

Date and Time of Day: April 20, 2005, AM

General Description: Despite snow on the ground contours are still visible. The falling snow gives a textured look and low cloud

cover limits distant views. The feature landscape is dominated by Paradise Valley, Sand Gulch, and Lost Wells Butte in the middle

ground. The area shows transitional-mixed land use; agricultural, industrial (oil), and residential. The foreground vegetation appears to be big sagebrush and mixed grasses. 


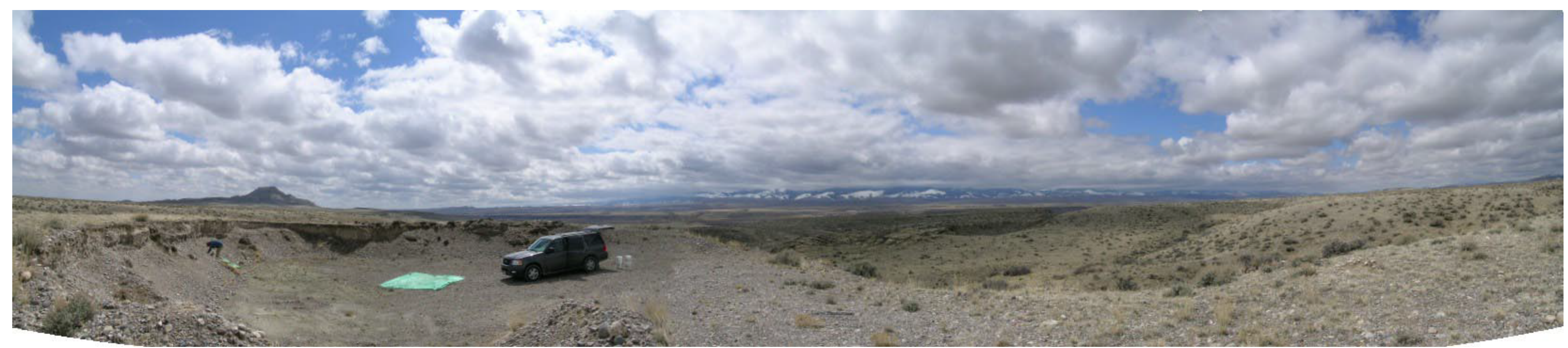

Plate Number 3

Location: CROWHEART BUTTE \# 1

View Direction: Southeast

Date and Time of Day: April 22, 2005, NOON

General Description: Clearing sky illuminates a feature landscape dominated by Crowheart Butte, a historical landmark, on the left.

The gently rolling hills give way to a vista of surrounding mountains. Terraces scarps and sandstone outcrops are noticeable. The

vegetation is sparse sagebrush and grasses. 
Plate Number 4

Location: E BOYSEN CAUSEWAY

View Direction: North

Date and Time of Day: April 24, 2005 AM

General Description: A panoramic landscape type with little vertical relief except for adjacent terraces and foothills. Water Tank

Hill (on right) adds to the scarcity of landform variety. The flat area is characterized by short grasses and sparse short brush.

Example of sand and gravel pit reclamation by the Wyoming Department of Transportation. 


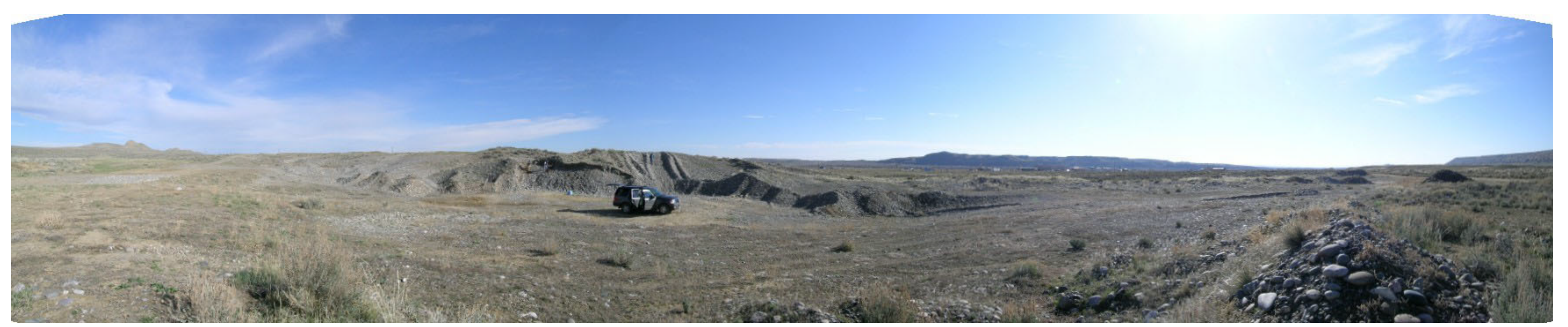

Plate Number 5

Location: JOHNSTOWN

View Direction: East

Date and Time of Day: April 23, 2005 AM

General Description Clear skies and a trace of clouds allow the panoramic landscape to be appreciated. The relatively flat terrain

of Johnstown Valley and adjacent terraces appear to blend together. The only vertical relief is the distant buttes. Even the small

sand and gravel heaps are visible from the main highway. Homes are less than $1 / 2$ mile away. 


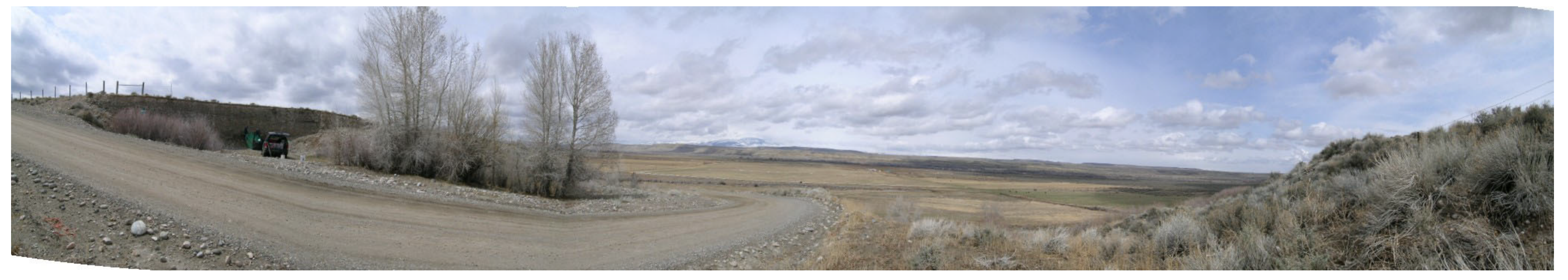

Plate Number 6

Location: KANE DRAW

View Direction: North

Date and Time of Day: April 21, 2005 PM

Gener Deription

General Description The terrace

of the Owl Creek Mountains. Shrubs domi

Urbigket Road crosses the landscape. 


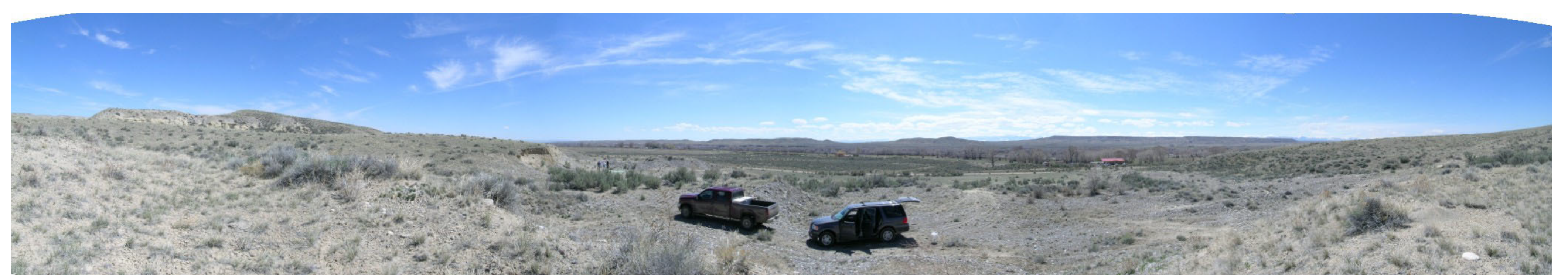

Plate Number 8

Location: LE CLAIR

View Direction: Southwest

Date and Time of Day: 23, 2005 PM

General Description: The foreground and middle ground do not substantially block views in this panoramic type landscape.

A large patch mosaic is formed by mounds of sagebrush, prickleypear cactus, cottonwoods, and grazing lands. Exposed

sandstone and the Wind River provide contrast in the landform. 


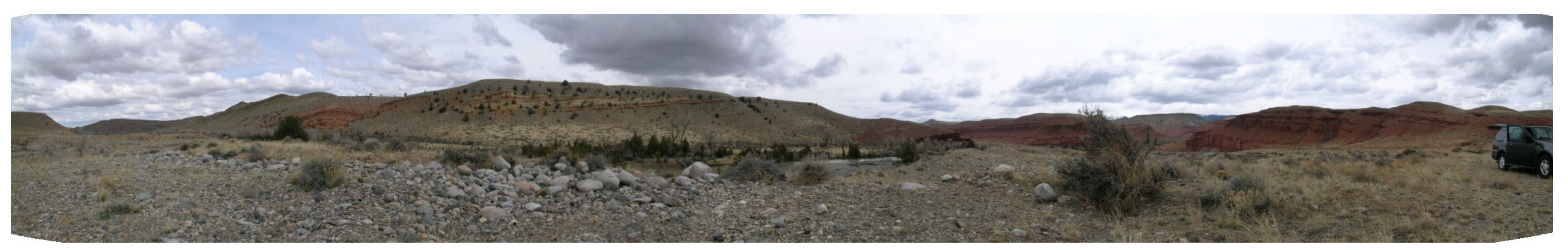

Plate Number 9

Location: RED ROCKS

View Direction: East

Date and Time of Day: April 24, 2005 PM

General Description: The narrow Wind River Valley floor and exposed bluffs form an enclosed landscape. Picturesque pines and

junipers are scattered across the area in small groups. Strands of cottonwood-willow mark the major drainage. Large grey river rocks

provide a color contrast to the exposed red-orange terrace slopes. 


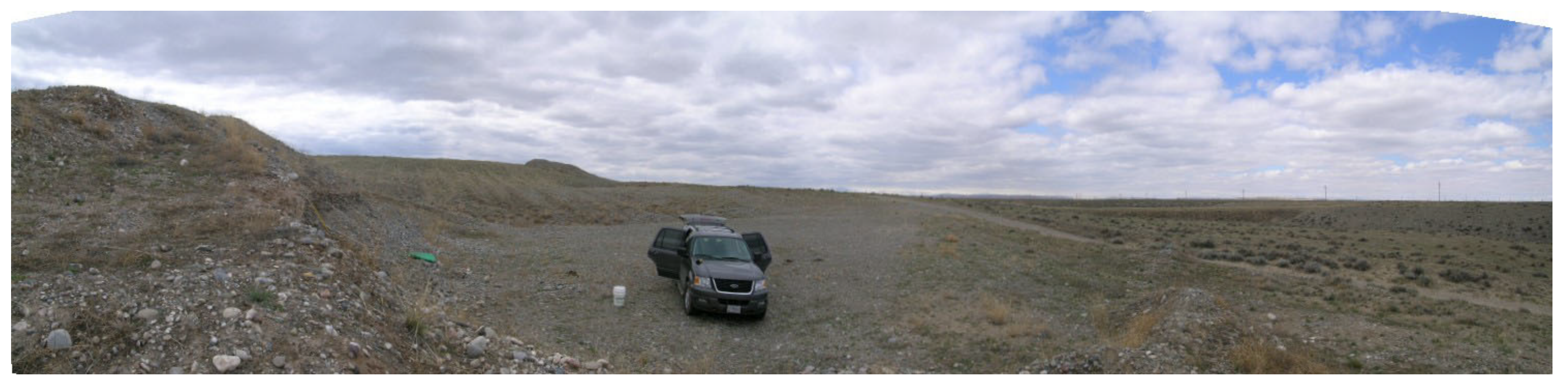

Plate Number 10

Location: SHEER

View Direction: West

Date and Time of Day: April 22, 2005 PM

General Description The isolated panoramic landscape has industrial development nearby. Typical vegetation is sparse and uneven. 


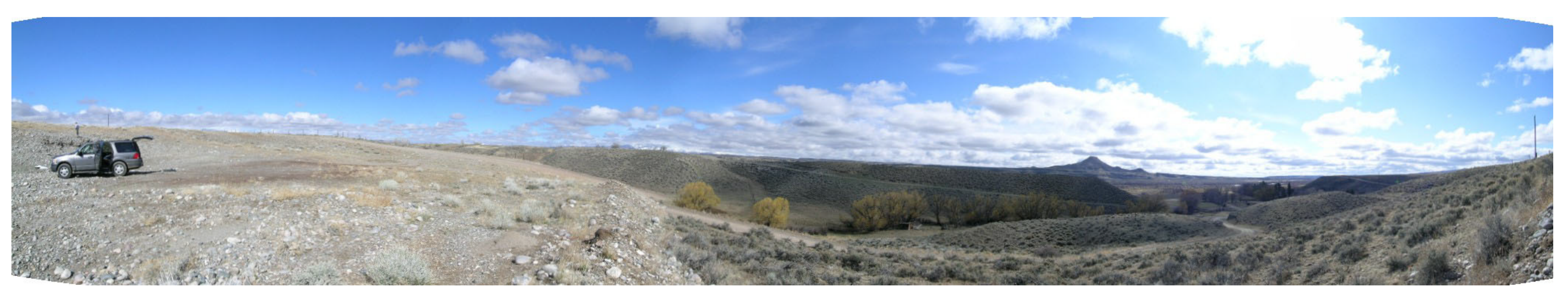

Plate Number 11

Location: WILLOWCREEK

View Direction: Northeast

Date and Time of Day: April 22, 2005

General Description The eye is led along a horizontal curve to distant Crowheat Butte and the Wind River Valley in this focal

landscape. Farming, ranching, and wildlife habitat make up the pastoral setting 


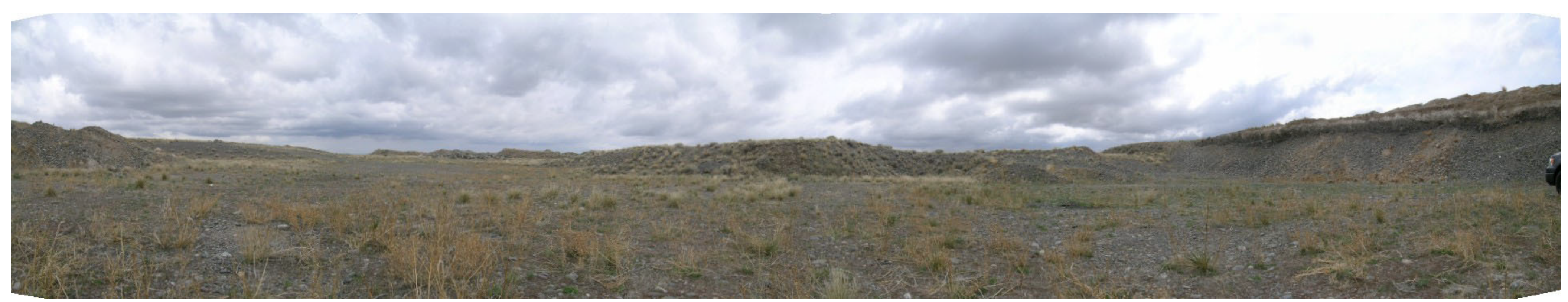

Plate Number 12

Location: WINKLEMAN DOME 1

View Direction: North

Date and Time of Day: April 21, 2005 AM

General Description This photograph is of a common wraparound horizon landscape in the Wind River Reservation. Flat

terrain with mountain backdrop (not visible in this view). Spoils are visible around the site and most of the vegetation is

uniformly colored and textured grasses. 


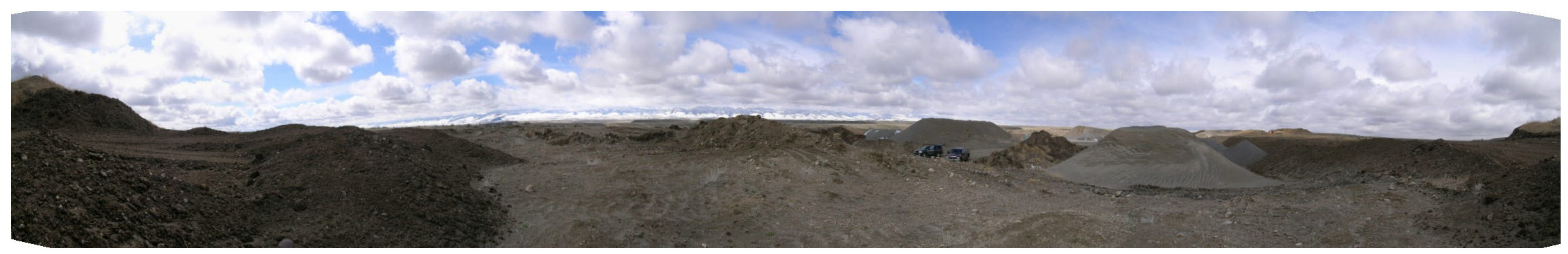

Plate Number 13

Location: WINKLEMAN DOME 2

View Direction: West

Date and Time of Day: April 21, 2005 NOON

General Description Atmospheric conditions mute the impact of the Wind River Mountains forming a dramatic backdrop.

The Shoshoni Tribe is actively processing sand and gravel on site and there is oil development to the east (out of observer's

view from this vantage point). Stock piles and overburden are in the foreground. The surrounding area is dominated by

sagebrush and grasses. 


\section{Appendix C-Engineering Test Results From Inberg-Miller Engineers}




\section{AGGREGATE LABORATORY TEST RESULTS SUMMARY SHEET}

D 124 E. Main Street Riverton, WY 82501 (307) 856-8136 (ph) (307) 856-3851 (fax)

\section{口 350 Parsley Boulevard Cheyenne, WY 82007 (307) 635-6827 (ph)} (307) 635-2713 (fax)

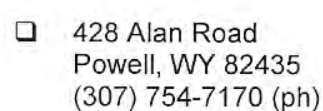

(307) $754-7170(\mathrm{ph})$

(307) $754-7088$ (fax)
520 Wilkes, Suite 13 Green River, WY 82935

(307) 875-4394 (ph)

(307) 875-4395 (fax)

\begin{tabular}{ll} 
Project: & Testing \\
\cline { 2 - 2 } Client: & USGS
\end{tabular}

Sample Type: Bulk, Native Gravel

Sampled By: Client

\section{$\mathrm{T}-84, \mathrm{~T}-85 /$}

C127,C12

\begin{tabular}{cr} 
Bulk Specific Gravity: & 2.575 \\
Percent Absorption: & $1.2 \%$ \\
\hline
\end{tabular}

Project No.:

Date:

Sample Source:

Sampled Date:
11919 RM

5-20-05
T-96/C131 Percent Loss by L.A. Abrasion Machine $\%$ Loss, 100 revolutions grading

A

$\%$ Loss, 500 revolutions

T-99/D698 Standard Proctor: $\quad$ Method:

Max Density: pcf

Opt. Moisture $\%$

T-180/D1557 Modified Proctor: Method:

Max Density: pcf

Opt. Moisture $\%$

T-19/C29 Unit Weight \& Percent Voids: Unit Wt: pcf $\%$ Voids:

$\mathrm{T}-21 / \mathrm{C} 40$ Organic Impurities in Fine Aggregate: Rating

$\mathrm{T}-89, \mathrm{~T}-90$

D4318

Atterberg Limits:

LL:

PL:

PI:

D2419/T-176 Sand Equivalent:

D1883/T-193 CBR Value:

Additional Tests:

\begin{tabular}{|c|c|c|c|}
\hline & $\begin{array}{r}\mathrm{T}-30 \\
\text { Sample }\end{array}$ & $\begin{array}{l}36 \\
\text { datio }\end{array}$ & \\
\hline Sieve & Percent & Spec & ation \\
\hline Size & & Low & High \\
\hline 3" & & & \\
\hline $2 \frac{1}{2 \prime}$ & 99 & & \\
\hline $2 "$ & 88 & & \\
\hline $11 / 2 "$ & 78 & & \\
\hline $1^{\prime \prime}$ & 64 & & \\
\hline $3 / 4 "$ & 54 & & \\
\hline $1 / 2 "$ & 42 & & \\
\hline $3 / 8 "$ & 37 & & \\
\hline$\# 4$ & 30 & & \\
\hline \#8 & 26 & & \\
\hline$\# 10$ & & & \\
\hline \#16 & 25 & & \\
\hline \#30 & 22 & & \\
\hline$\# 40$ & & & \\
\hline$\# 50$ & 8 & & \\
\hline \#100 & 2 & & \\
\hline \#200 & 0.9 & & \\
\hline
\end{tabular}

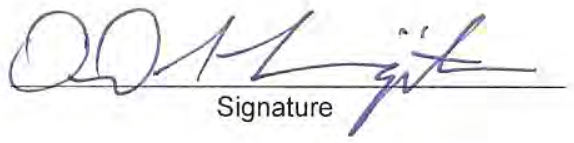

C88

Soundness by Sodium Sulfate:

\begin{tabular}{|c|c|}
\hline Sieve Size: & Weighted \% Loss: \\
\hline$-1.5 "-+0.75 "$ & 0.1 \\
\hline$-0.75 "-+0.375$ & 0.2 \\
\hline$-0.375-\# 4$ & 0.1 \\
\hline & \\
\hline & \\
\hline
\end{tabular}




\section{AGGREGATE LABORATORY TEST RESULTS SUMMARY SHEET}

124 E. Main Street Riverton, WY 82501 (307) 856-8136 (ph) (307) 856-3851 (fax)

口 1120 E. "C" Street Casper, WY 82601 (307) 577-0806 (ph) (307) 472-4402 (fax)
- 350 Parsley Boulevard Cheyenne, WY 82007 (307) 635-6827 (ph) (307) 635-2713 (fax)

\section{- 428 Alan Road Powell, WY 82435 (307) 754-7170 (ph)} (307) 754-7088 (fax)
- 520 Wilkes, Suite 13 Green River, WY 82935 (307) 875-4394 (ph) (307) 875-4395 (fax)

\begin{tabular}{ll} 
Project: & Testing \\
Client: & USGS \\
\hline
\end{tabular}

Sample Type: Bulk, Native Gravel

Sampled By: Client
Project No.:

Date:

11919 RM

$5-12-05$

Sample Source:

Burma Hill \# 1
T-84, T-85/

$\mathrm{C} 127, \mathrm{C} 12$

\begin{tabular}{cc} 
Bulk Specific Gravity: & 2.533 \\
& \\
Percent Absorption: & $1.6 \%$ \\
\hline
\end{tabular}

T-96/C131 Percent Loss by L.A. Abrasion Machine $\%$ Loss, 100 revolutions

grading: A $\%$ Loss, 500 revolutions 27.4 T-99/D698 Standard Proctor: Method Max Density: pcf Opt. Moisture $\%$

T-180/D1557 Modified Proctor: Method:

Max Density: pcf Opt. Moisture $\%$

T-19/C29 Unit Weight \& Percent Voids: Unit Wt: pcf \% Voids:

$\mathrm{T}-21 / \mathrm{C} 40$ Organic Impurities in Fine Aggregate: Rating

$\mathrm{T}-89, \mathrm{~T}-90$

D4318

Atterberg Limits:

LL:

PL:

$\mathrm{Pl}:$

D2419/T-176 Sand Equivalent:

D1883/T-193 CBR Value:

Additional Tests:

\begin{tabular}{|c|c|c|c|}
\hline & $\begin{array}{r}\mathrm{T}-30 / \\
\text { Sample }\end{array}$ & $\begin{array}{l}36 \\
\text { datio }\end{array}$ & \\
\hline Sieve & Percent & Spec & ation \\
\hline Size & & Low & High \\
\hline $3 "$ & & & \\
\hline $2 \frac{1}{2} "$ & 99 & & \\
\hline $2 "$ & 90 & & \\
\hline $11 / 2 "$ & 82 & & \\
\hline $1 "$ & 68 & & \\
\hline $3 / 4 "$ & 60 & & \\
\hline $1 / 2 "$ & 50 & & \\
\hline $3 / 8 "$ & 46 & & \\
\hline \#4 & 39 & & \\
\hline$\# 8$ & 34 & & \\
\hline \#10 & & & \\
\hline \#16 & 27 & & \\
\hline \#30 & 16 & & \\
\hline \#40 & & & \\
\hline \#50 & 6 & & \\
\hline \#100 & 4 & & \\
\hline \#200 & 2.7 & & \\
\hline
\end{tabular}

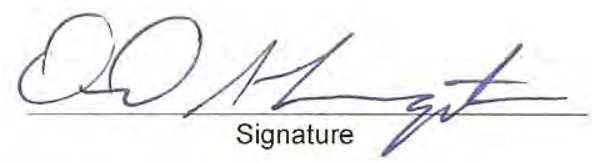

C88

Soundness by Sodium Sulfate:

\begin{tabular}{|c|c|}
\hline Sieve Size: & Weighted \% Loss: \\
\hline$-1.5 "-+0.75 "$ & 1.6 \\
\hline$-0.75 "-+0.375$ & 0.7 \\
\hline$-0.375-\# 4$ & 0.2 \\
\hline & \\
\hline & \\
\hline
\end{tabular}




\section{AGGREGATE LABORATORY TEST RESULTS SUMMARY SHEET}

124 E. Main Street Riverton, WY 82501 (307) 856-8136 (ph)

(307) 856-3851 (fax)

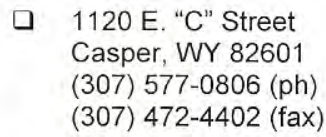
口 350 Parsley Boulevard Cheyenne, WY 82007
(307) 635-6827 (ph)

(307) 635-2713 (fax)

\section{- 428 Alan Road Powell, WY 82435 (307) 754-7170 (ph)}

(307) 754-7088 (fax)
口 520 Wilkes, Suite 13 Green River, WY 82935

(307) 875-4394 (ph)

(307) 875-4395 (fax)

\begin{tabular}{ll} 
Project: & Testing \\
\cline { 2 - 2 } Client: & USGS \\
\hline
\end{tabular}

Sample Type: Bulk, Native Gravel

Sampled By: Client
Project No.:

Date:

Sample Source:

Sampled Date:
T-84, T-85/

C127,C128 Bulk Specific Gravity:

2.527

Percent Absorption:

$1.8 \%$

T-96/C131 Percent Loss by L.A. Abrasion Machine $\%$ Loss, 100 revolutions

grading:

A

$\%$ Loss, 500 revolutions

25.6

T-99/D698 Standard Proctor:

Method:

Max Density: pcf

Opt. Moisture $\%$

T-180/D1557 Modified Proctor: Method:

Max Density: pcf Opt. Moisture $\%$

T-19/C29 Unit Weight \& Percent Voids: Unit Wt: pcf \% Voids:

T-21/C40 Organic Impurities in Fine Aggregate: Rating

$\mathrm{T}-89, \mathrm{~T}-90$

D4318

$$
\text { Atterberg Limits: }
$$

LL:

PL:

$\mathrm{Pl}:$

D2419/T-176 Sand Equivalent:

D1883/T-193 CBR Value:

Additional Tests:

\begin{tabular}{|c|c|c|c|}
\hline \multicolumn{4}{|c|}{ T-30/C136 } \\
\multicolumn{3}{|c|}{ Sample Gradation } \\
\hline Sieve & Percent & Specification \\
Size & Finer & Low & High \\
\hline $3 "$ & & & \\
$21 / 2^{\prime \prime}$ & 97 & \\
$2 "$ & 93 & \\
$11 / 2 "$ & 86 & \\
$1 "$ & 73 & \\
$3 / 4 "$ & 65 & \\
$1 / 2 "$ & 56 & \\
$3 / 8 "$ & 51 & \\
$\# 4$ & 44 & \\
$\# 8$ & 39 & \\
$\# 10$ & & \\
$\# 16$ & 30 & \\
$\# 30$ & 18 & \\
$\# 40$ & & \\
$\# 50$ & 10 & \\
$\# 100$ & 5 & \\
\#200 & 3.7 & \\
\end{tabular}

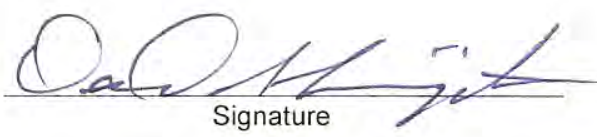

C88

Soundness by Sodium Sulfate:

\begin{tabular}{|c|c|}
\hline Sieve Size: & Weighted \% Loss: \\
\hline$-1.5 "-+0.75 "$ & 0.4 \\
\hline$-0.75 "-+0.375$ & 0.4 \\
\hline$-0.375-\# 4$ & 0.4 \\
\hline & \\
\hline & \\
\hline
\end{tabular}

F:111919l11919 Burma Hill \#1 AGGREGATE SUMM SHEET. doc 


\section{AGGREGATE \\ LABORATORY TEST RESULTS \\ SUMMARY SHEET}

- 124 E. Main Street Riverton, WY 82501 (307) 856-8136 (ph) (307) 856-3851 (fax)
1120 E. "C" Street Casper, WY 82601 (307) 577-0806 (ph) (307) 472-4402 (fax)
a 350 Parsley Boulevard Cheyenne, WY 82007 (307) 635-6827 (ph)
(307) 635-2713 (fax)

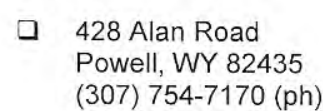

(307) 754-7170 (ph)

(307) 754-7088 (fax)
- 520 Wilkes, Suite 13 Green River, WY 82935

(307) 875-4394 (ph)

(307) 875-4395 (fax)

\begin{tabular}{ll} 
Project: & Testing \\
\cline { 2 - 2 } Client: & USGS \\
\hline
\end{tabular}

Sample Type: Bulk, Native Gravel

Sampled By: Client

T-84,T-85/

C127,C128

Bulk Specific Gravity:

2.572

Percent Absorption:

$1.3 \%$

T-96/C131 Percent Loss by L.A. Abrasion Machine

$\%$ Loss, 100 revolutions

grading:

A

Project No.:

11919 RM

Date:

5-12-05

Sample Source: Burma Hill \# 3

Sampled Date: $\%$ Loss, 500 revolutions 26.4

T-99/D698 Standard Proctor: Method

Max Density: pcf

Opt. Moisture $\%$

T-180/D1557 Modified Proctor: Method:

Max Density: pcf Opt. Moisture $\%$

T-19/C29 Unit Weight \& Percent Voids: Unit Wt: pcf $\%$ Voids:

$\mathrm{T}-21 / \mathrm{C} 40$

$\mathrm{T}-89, \mathrm{~T}-90$

D4318

Organic Impurities in Fine Aggregate:

Rating:

Atterberg Limits: LL:

PL:

$\mathrm{PI}$

D2419/T-176 Sand Equivalent:

D1883/T-193 CBR Value:

Additional Tests:

\begin{tabular}{|c|c|c|c|}
\hline \multicolumn{4}{|c|}{ T-30/C136 } \\
\multicolumn{4}{|c|}{ Sample Gradation } \\
\hline Sieve & Percent & Specification \\
\hline Size & Finer & Low & High \\
\hline $3 "$ & & & \\
$21 / 2 "$ & 94 & & \\
$2 "$ & 80 & \\
$11 / 2 "$ & 69 & \\
$1 "$ & 57 & \\
$3 / 4 "$ & 51 & \\
$1 / 2 "$ & 45 & \\
$3 / 8 "$ & 42 & \\
$\# 4$ & 37 & \\
$\# 8$ & 31 & \\
$\# 10$ & & \\
$\# 16$ & 27 & \\
$\# 30$ & 16 & \\
$\# 40$ & & \\
$\# 50$ & 8 & \\
$\# 100$ & 4 & \\
\#200 & 2.5 & \\
\end{tabular}

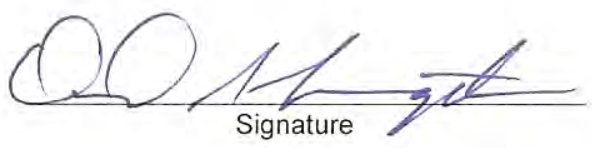

C88

Soundness by Sodium Sulfate:

\begin{tabular}{|c|c|}
\hline Sieve Size: & Weighted \% Loss: \\
\hline$-1.5 "-+0.75 "$ & 1.4 \\
\hline$-0.75 "-+0.375$ & 0.2 \\
\hline$-0.375-\# 4$ & 0.3 \\
\hline & \\
\hline & \\
\hline
\end{tabular}




\section{AGGREGATE LABORATORY TEST RESULTS SUMMARY SHEET}

XX 124 E. Main Street Riverton, WY 82501 (307) 856-8136 (ph) (307) 856-3851 (fax)
1120 E. "C" Street (307) 577-0806 (ph)

(307) 472-4402 (fax)
- 350 Parsley Boulevard Cheyenne, WY 82007 (307) 635-6827 (ph) (307) 635-2713 (fax)
- 428 Alan Road Powell, WY 82435 (307) $754-7170(\mathrm{ph})$ (307) 754-7088 (fax)
- 520 Wilkes, Suite 13 Green River, WY 82935

(307) 875-4394 (ph)

(307) 875-4395 (fax)

\begin{tabular}{ll} 
Project: & Testing \\
\cline { 2 - 2 } Client: & USGS \\
\cline { 2 - 2 } Sample Type: & Bulk, Native Gravel \\
\cline { 2 - 2 } Sampled By: & Client
\end{tabular}

Project No.:

Date:

11919 RM

Sample Source: Crowheart Butte Pit \#1

\section{Sampled Date:}

$\mathrm{T}-84, \mathrm{~T}-85 /$

C127,C128

\begin{tabular}{cc} 
Bulk Specific Gravity: & 2.502 \\
Percent Absorption: & $2.0 \%$ \\
\hline
\end{tabular}

T-96/C131 Percent Loss by L.A. Abrasion Machine grading: A $\%$ Loss, 100 revolutions \% Loss, 500 revolutions 29.3

T-99/D698 Standard Proctor: $\quad$ Method:

Max Density: pcf Opt. Moisture

T-180/D1557 Modified Proctor: Method:

Max Density: pcf Opt. Moisture

T-19/C29 Unit Weight \& Percent Voids: Unit Wt: pcf $\%$ Voids:

$\mathrm{T}-21 / \mathrm{C} 40$ Organic Impurities in Fine Aggregate: Rating:

$\mathrm{T}-89, \mathrm{~T}-90$

D4318

Atterberg Limits:

LL: PL: PI:

D2419/T-176 Sand Equivalent:

D1883/T-193 CBR Value:

Additional Tests:

Note: Minor to light caliche deposits on aggregate

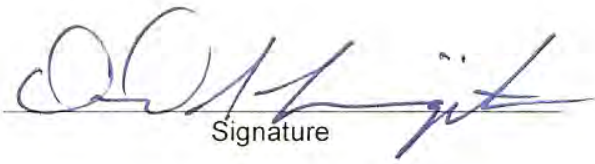
$\%$ $\%$

\begin{tabular}{|c|c|c|c|}
\hline \multicolumn{4}{|c|}{$\begin{array}{c}\text { T-30/C136 } \\
\text { Sample Gradation }\end{array}$} \\
\hline \multirow{2}{*}{$\begin{array}{l}\text { Sieve } \\
\text { Size }\end{array}$} & \multirow{2}{*}{$\begin{array}{l}\text { Percent } \\
\text { Finer }\end{array}$} & \multicolumn{2}{|c|}{ Specification } \\
\hline & & Low & High \\
\hline $3 "$ & 100 & & \\
\hline $21 / 2 "$ & 92 & & \\
\hline $2 "$ & 87 & & \\
\hline $11 / 2 "$ & 82 & & \\
\hline 1" & 70 & & \\
\hline $3 / 4 "$ & 63 & & \\
\hline $1 / 2 "$ & 53 & & \\
\hline $3 / 8^{4}$ & 48 & & \\
\hline \#4 & 36 & & \\
\hline \#8 & 28 & & \\
\hline \#10 & & & \\
\hline \#16 & 21 & & \\
\hline \#30 & 15 & & \\
\hline$\# 40$ & & & \\
\hline \#50 & 9 & & \\
\hline \#100 & 4 & & \\
\hline \#200 & 2.3 & & \\
\hline
\end{tabular}

C88

Soundness by Sodium Sulfate:

\begin{tabular}{|c|c|}
\hline Sieve Size: & Weighted \% Loss: \\
\hline$-1.5^{\prime \prime}-+0.75 "$ & 1.0 \\
\hline$-0.75^{\prime \prime}-+0.375$ & 1.4 \\
\hline$-0.375-\# 4$ & 1.3 \\
\hline & \\
\hline & \\
\hline
\end{tabular}

F:I11919l11919 Johnstown Pit \#1 AGGREGATE SUMM SHEET doc 


\section{AGGREGATE LABORATORY TEST RESULTS SUMMARY SHEET}

XX 124 E. Main Street Riverton, WY 82501 (307) 856-8136 (ph) (307) 856-3851 (fax)

\section{口 350 Parsley Boulevard Cheyenne, WY 82007 (307) 635-6827 (ph)} (307) 635-2713 (fax)

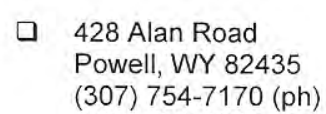

(307) 577-0806 (ph)

(307) 472-4402 (fax)
(307) 754-7170 (ph)

(307) 754-7088 (fax)
- 520 Wilkes, Suite 13 Green River, WY 82935

(307) 875-4394 (ph)

(307) 875-4395 (fax)

\begin{tabular}{ll} 
Project: & Testing \\
\cline { 2 - 2 } Client: & USGS \\
\hline
\end{tabular}

Sample Type: Bulk, Native Gravel

Sampled By: Client

\section{$\mathrm{T}-84, \mathrm{~T}-85 /$}

C127,C128

$\begin{array}{cc}\text { Bulk Specific Gravity: } & 2.592 \\ & \\ \text { Percent Absorption: } & 1.3 \%\end{array}$
Project No.:

Date:

Sample Source:

Sampled Date:
11919 RM

6-23-05

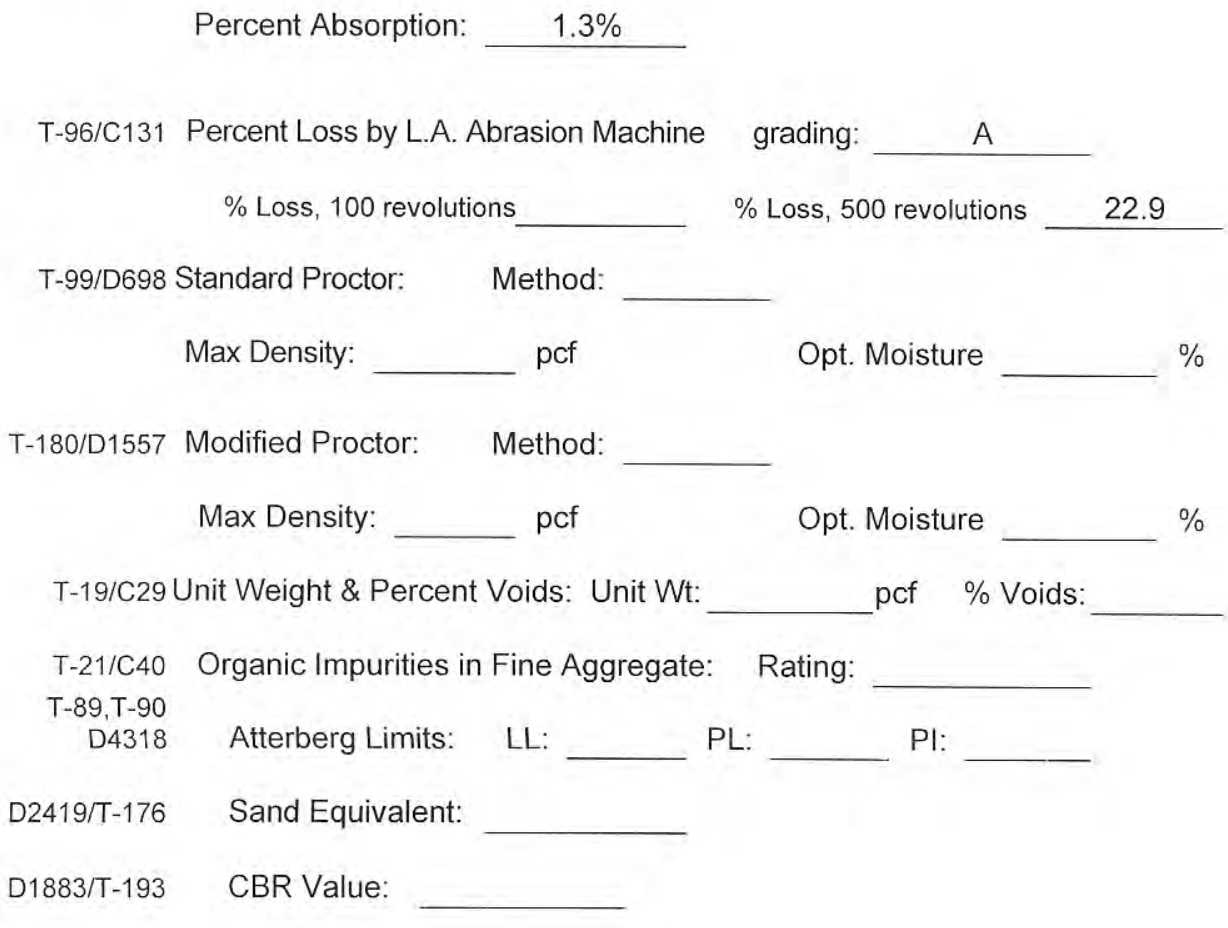

Additional Tests:

\begin{tabular}{|c|c|c|c|}
\hline \multicolumn{4}{|c|}{$\begin{array}{c}\text { T-30/C136 } \\
\text { Sample Gradation }\end{array}$} \\
\hline \multirow{2}{*}{$\begin{array}{l}\text { Sieve } \\
\text { Size }\end{array}$} & \multirow{2}{*}{$\begin{array}{l}\text { Percent } \\
\text { Finer }\end{array}$} & \multicolumn{2}{|c|}{ Specification } \\
\hline & & Low & High \\
\hline $3 "$ & 100 & & \\
\hline $2 \frac{1}{2} "$ & 93 & & \\
\hline 2" & 87 & & \\
\hline $11 / 2^{\prime \prime}$ & 78 & & \\
\hline 1" & 64 & & \\
\hline $3 / 4 "$ & 57 & & \\
\hline $1 / 2 "$ & 47 & & \\
\hline $3 / 8 "$ & 42 & & \\
\hline \#4 & 34 & & \\
\hline \#8 & 29 & & \\
\hline \#10 & & & \\
\hline \#16 & 26 & & \\
\hline \#30 & 20 & & \\
\hline \#40 & & & \\
\hline \#50 & 9 & & \\
\hline \#100 & 4 & & \\
\hline \#200 & 1.8 & & \\
\hline
\end{tabular}

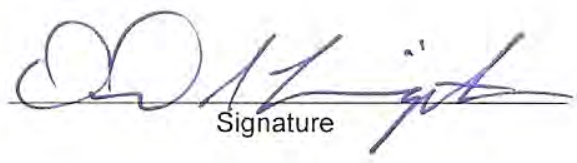

\begin{tabular}{|c|c|}
\hline \multicolumn{2}{|c|}{ C88 } \\
\hline \multicolumn{2}{|c|}{ Soundness by Sodium Sulfate: } \\
\hline Sieve Size: & Weighted \% Loss: \\
\hline$-1.5 "-+0.75 "$ & 0.2 \\
\hline$-0.75^{\prime \prime}-+0.375$ & 0.2 \\
\hline$-0.375-\# 4$ & 0.1 \\
\hline & \\
\hline & \\
\hline
\end{tabular}

F:111919l11919Kineer Pit \#1 AGGREGATE SUMM SHEET doc 


\section{AGGREGATE LABORATORY TEST RESULTS SUMMARY SHEET}

124 E. Main Street Riverton, WY 82501 (307) 856-8136 (ph) (307) 856-3851 (fax)
口 350 Parsley Boulevard Cheyenne, WY 82007 (307) 635-6827 (ph) (307) 635-2713 (fax)

\section{- 428 Alan Road Powell, WY 82435 (307) 754-7170 (ph)} (307) 754-7088 (fax)
口 520 Wilkes, Suite 13 Green River, WY 82935

(307) 875-4394 (ph)

(307) 875-4395 (fax)

\begin{tabular}{ll} 
Project: & Testing \\
\cline { 2 - 2 } Client: & USGS \\
\hline
\end{tabular}

Sample Type: Bulk, Native Gravel

Sampled By: Client
Project No.:

Date:

11919 RM

5-20-05

Sample Source:

Kane Draw Site \#1

Sampled Date:
$\mathrm{T}-84, \mathrm{~T}-85 /$

$\mathrm{C} 127, \mathrm{C} 128$

\begin{tabular}{cc} 
Bulk Specific Gravity: & 2.576 \\
& \\
Percent Absorption: & $1.6 \%$ \\
\hline
\end{tabular}

\begin{tabular}{|c|c|c|c|}
\hline \multicolumn{4}{|c|}{ T-30/C136 } \\
\hline \multicolumn{3}{|c|}{ Sample Gradation } \\
\hline Sieve & Percent & Specification \\
\hline Size & Finer & Low & High \\
\hline $3 "$ & & & \\
$21 / 2^{\prime \prime}$ & 91 & & \\
$2 "$ & 80 & \\
$11 / 2 "$ & 66 & \\
$1 "$ & 49 & \\
$3 / 4 "$ & 40 & \\
$1 / 2 "$ & 31 & \\
$3 / 8 "$ & 26 & \\
$\# 4$ & 19 & \\
$\# 8$ & 16 & \\
$\# 10$ & & \\
$\# 16$ & 13 & \\
$\# 30$ & 8 & \\
$\# 40$ & & \\
$\# 50$ & 4 & \\
$\# 100$ & 2 & \\
\\
\#200 & 1.7 & \\
\end{tabular}

Additional Tests:

grading:

A

\% Loss, 500 revolutions

26.2

T-99/D698 Standard Proctor: Method:

Max Density: pcf

Opt. Moisture $\%$

T-180/D1557 Modified Proctor: Method:

Max Density: pcf

Opt. Moisture $\%$

T-19/C29 Unit Weight \& Percent Voids: Unit Wt: pcf \% Voids:

$\mathrm{T}-21 / \mathrm{C} 40$ Organic Impurities in Fine Aggregate: Rating:

T-89, T-90

D4318

Atterberg Limits:

LL: PL: $\mathrm{PI}$

D2419/T-176 Sand Equivalent:

D1883/T-193 CBR Value:

C88

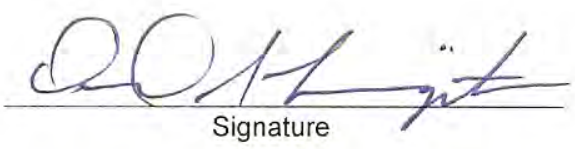

\begin{tabular}{|c|c|}
\hline \multicolumn{2}{|c|}{ C88 } \\
Soundness by Sodium Sulfate: \\
\hline Sieve Size: & Weighted \% Loss: \\
\hline$-1.5 "-+0.75 "$ & 0.6 \\
\hline$-0.75^{\prime \prime}-+0.375$ & 0.4 \\
\hline$-0.375-\# 4$ & 0.4 \\
\hline & \\
\hline & \\
\hline
\end{tabular}




\section{AGGREGATE LABORATORY TEST RESULTS SUMMARY SHEET}

XX 124 E. Main Street Riverton, WY 82501 (307) 856-8136 (ph) (307) 856-3851 (fax)

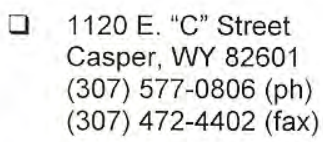

口 1120 E. "C" Street Casper, WY 82601 (307) 577-0806 (ph) (307) 472-4402 (fax)

- 350 Parsley Boulevard Cheyenne, WY 82007 (307) 635-6827 (ph) (307) 635-2713 (fax)
428 Alan Road Powell, WY 82435 (307) 754-7170 (ph) (307) 754-7088 (fax)

- 520 Wilkes, Suite 13 Green River, WY 82935

(307) 875-4394 (ph)

(307) 875-4395 (fax)

\begin{tabular}{ll} 
Project: & Testing \\
\cline { 2 - 2 } Client: & USGS
\end{tabular}

Sample Type: Bulk, Native Gravel

Sampled By: Client
Project No:

Date:

$11919 \mathrm{RM}$

6-23-05

Sample Source: Kineer Pit \#1

\section{Sampled Date:}

T-84,T-85/

C127,C128 Bulk Specific Gravity: 2.591

Percent Absorption: $1.4 \%$

T-96/C131 Percent Loss by L.A. Abrasion Machine $\%$ Loss, 100 revolutions

grading: A \% Loss, 500 revolutions 21.8 T-99/D698 Standard Proctor: Method: Max Density: pcf Opt. Moisture $\%$

T-180/D1557 Modified Proctor: Method:

Max Density: pcf Opt. Moisture $\%$

T-19/C29 Unit Weight \& Percent Voids: Unit Wt: pcf $\%$ Voids:

T-21/C40 Organic Impurities in Fine Aggregate: Rating:

$\mathrm{T}-89, \mathrm{~T}-90$

D4318

Atterberg Limits:

LL:

PL:

PI:

D2419/T-176 Sand Equivalent:

D1883/T-193 CBR Value:

Additional Tests:

\begin{tabular}{|c|c|c|c|}
\hline & $\begin{array}{r}\text { T-30l } \\
\text { Sample }\end{array}$ & $\begin{array}{l}36 \\
\text { datio }\end{array}$ & \\
\hline Sieve & Percent & Spec & ation \\
\hline Size & & Low & High \\
\hline 3" & 100 & & \\
\hline $2 \frac{1}{2 \prime}$ & 94 & & \\
\hline $2 "$ & 85 & & \\
\hline $11 / 2^{\prime \prime}$ & 74 & & \\
\hline $1 "$ & 63 & & \\
\hline $3 / 4 "$ & 53 & & \\
\hline $1 / 2 "$ & 43 & & \\
\hline $3 / 8^{16}$ & 38 & & \\
\hline$\# 4$ & 30 & & \\
\hline \#8 & 26 & & \\
\hline \#10 & & & \\
\hline$\# 16$ & 23 & & \\
\hline \#30 & 17 & & \\
\hline$\# 40$ & & & \\
\hline$\# 50$ & 8 & & \\
\hline \#100 & 4 & & \\
\hline \#200 & 1.7 & & \\
\hline
\end{tabular}

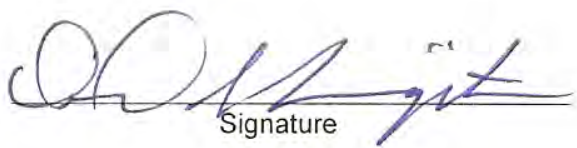

C88

Soundness by Sodium Sulfate:

\begin{tabular}{|c|c|}
\hline Sieve Size: & Weighted \% Loss: \\
\hline$-1.5 "-+0.75 "$ & 0.2 \\
\hline$-0.75 "-+0.375$ & 0.2 \\
\hline$-0.375-\# 4$ & 0.1 \\
\hline & \\
\hline & \\
\hline
\end{tabular}

F:I11919\11919Kineer Pit \#1 AGGREGATE SUMM SHEET doc 


\section{AGGREGATE LABORATORY TEST RESULTS SUMMARY SHEET}

XX 124 E. Main Street Riverton, WY 82501 (307) 856-8136 (ph) (307) 856-3851 (fax)

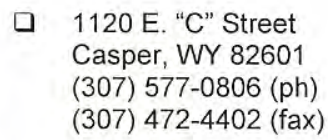
350 Parsley Boulevard Cheyenne, WY 82007
(307) 635-6827 (ph)

(307) 635-2713 (fax)

\section{- 428 Alan Road Powell, WY 82435 (307) 754-7170 (ph)} (307) 754-7088 (fax)
520 Wilkes, Suite 13 Green River, WY 82935

(307) 875-4394 (ph)

(307) 875-4395 (fax)

\begin{tabular}{ll} 
Project: & Testing \\
\cline { 2 - 2 } Client: & USGS
\end{tabular}

Sample Type: Bulk, Native Gravel

Sampled By: Client
Project No.:

Date:

Sample Source: LeClair Pit \#1 (ALC)

Sampled Date:
T-84, T-85/

C127,C128

Bulk Specific Gravity:

2.553

Percent Absorption:

$1.5 \%$

T-96/C131 Percent Loss by L.A. Abrasion Machine

$\%$ Loss, 100 revolutions

grading:

A

$\%$ Loss, 500 revolutions

22.7

T-99/D698 Standard Proctor:

Method:

Max Density: pcf

Opt. Moisture $\%$

T-180/D1557 Modified Proctor: Method:

Max Density: pcf

Opt. Moisture $\%$

T-19/C29 Unit Weight \& Percent Voids: Unit Wt: pcf $\%$ Voids:

$\mathrm{T}-21 / \mathrm{C} 40$ Organic Impurities in Fine Aggregate: Rating:

$\mathrm{T}-89, \mathrm{~T}-90$

D4318

Atterberg Limits:

LL:

PL:

$\mathrm{Pl}:$

D2419/T-176 Sand Equivalent:

D1883/T-193 CBR Value:

Additional Tests:

\begin{tabular}{|c|c|c|c|}
\hline \multicolumn{4}{|c|}{ T-30/C136 } \\
\hline \multicolumn{3}{|c|}{ Sample Gradation } \\
\hline Sieve & Percent & \multicolumn{2}{|c|}{ Specification } \\
\cline { 3 - 4 } Size & Finer & Low & High \\
\hline $3 "$ & 100 & & \\
$21 / 2 "$ & 97 & & \\
$2 "$ & 93 & \\
$11 / 2 "$ & 81 & \\
$1 "$ & 65 & \\
$3 / 4 "$ & 56 & \\
$1 / 2 "$ & 44 & \\
$3 / 8 "$ & 40 & \\
$\# 4$ & 33 & \\
$\# 8$ & 30 & \\
$\# 10$ & & \\
$\# 16$ & 28 & \\
$\# 30$ & 23 & \\
$\# 40$ & & \\
$\# 50$ & 11 & \\
$\# 100$ & 5 & \\
\end{tabular}

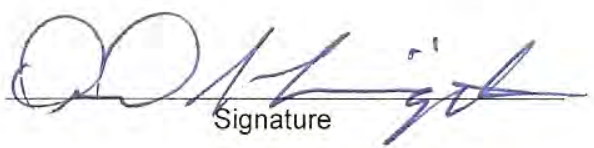

\begin{tabular}{|c|c|}
\hline \multicolumn{2}{|c|}{ C88 } \\
Soundness by Sodium Sulfate: \\
\hline Sieve Size: & Weighted \% Loss: \\
\hline$-1.5 "-+0.75 "$ & 0.3 \\
\hline$-0.75 "-+0.375$ & 0.4 \\
\hline$-0.375-\# 4$ & 0.3 \\
\hline & \\
\hline & \\
\hline
\end{tabular}




\section{AGGREGATE LABORATORY TEST RESULTS SUMMARY SHEET}

XX 124 E. Main Street Riverton, WY 82501 (307) 856-8136 (ph)

(307) 856-3851 (fax)
1120 E. "C" Street
Casper, WY 82601
(307) 577-0806 (ph

(307) 472-4402 (fax)
- 350 Parsley Boulevard Cheyenne, WY 82007 (307) 635-6827 (ph) (307) 635-2713 (fax)
- 428 Alan Road Powell, WY 82435 (307) 754-7170 (ph) (307) $754-7088$ (fax)
- 520 Wilkes, Suite 13 Green River, WY 82935

(307) 875-4394 (ph)

(307) 875-4395 (fax)
Project:

Testing

Client: USGS

Sample Type: Bulk, Native Gravel

Sampled By:
Project No.:

Date:

Sample Source: Sheer Pit \#1

Sampled Date:
T-84,T-85/

C127,C128 Bulk Specific Gravity:

Percent Absorption

$1.3 \%$

T-96/C131 Percent Loss by L.A. Abrasion Machine $\%$ Loss, 100 revolutions

grading: A $\%$ Loss, 500 revolutions

T-99/D698 Standard Proctor: Method:

Max Density: pcf

Opt. Moisture

T-180/D1557 Modified Proctor: $\quad$ Method:

Max Density: pcf Opt. Moisture

T-19/C29 Unit Weight \& Percent Voids: Unit Wt: pcf \% Voids:

$\mathrm{T}-21 / \mathrm{C} 40$ Organic Impurities in Fine Aggregate: Rating:

$\mathrm{T}-89, \mathrm{~T}-90$

D4318

Atterberg Limits:

LL: PL: $\mathrm{Pl}:$

D2419/T-176

D1883/T-193 Sand Equivalent:

CBR Value:

Additional Tests:

Note: Minor to light caliche deposits on aggregate

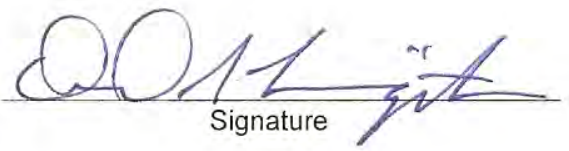
26.4 $\%$ $\%$

T-30/C136

Sample Gradation

\begin{tabular}{|c|c|c|c|}
\hline \multirow{2}{*}{$\begin{array}{l}\text { Sieve } \\
\text { Size }\end{array}$} & \multirow{2}{*}{$\begin{array}{l}\text { Percent } \\
\text { Finer }\end{array}$} & \multicolumn{2}{|c|}{ Specification } \\
\hline & & Low & High \\
\hline $3 "$ & 100 & & \\
\hline $21 / 2 "$ & 89 & & \\
\hline $2 "$ & 85 & & \\
\hline $11 / 2 "$ & 68 & & \\
\hline $1 "$ & 53 & & \\
\hline $3 / 4 "$ & 44 & & \\
\hline $1 / 2 "$ & 35 & & \\
\hline $3 / 8 "$ & 31 & & \\
\hline$\# 4$ & 24 & & \\
\hline \#8 & 20 & & \\
\hline$\# 10$ & & & \\
\hline$\# 16$ & 18 & & \\
\hline \#30 & 14 & & \\
\hline$\# 40$ & & & \\
\hline \#50 & 7 & & \\
\hline \#100 & 4 & & \\
\hline \#200 & 2.4 & & \\
\hline
\end{tabular}

C88

Soundness by Sodium Sulfate:

\begin{tabular}{|c|c|}
\hline Sieve Size: & Weighted \% Loss: \\
\hline$-1.5 "-+0.75 "$ & 0.4 \\
\hline$-0.75 "-+0.375$ & 0.3 \\
\hline$-0.375-\# 4$ & 0.4 \\
\hline & \\
\hline & \\
\hline
\end{tabular}

F:111919l11919 Crowheart Butte Pit \#1 (LC)AGGREGATE SUMM SHEET, doc 


\section{AGGREGATE LABORATORY TEST RESULTS SUMMARY SHEET}

XX 124 E. Main Street Riverton, WY 82501 (307) 856-8136 (ph) (307) 856-3851 (fax)
口 1120 E. "C" Street Casper, WY 82601 (307) 577-0806 (ph) (307) 472-4402 (fax) a 350 Parsley Boulevard Cheyenne, WY 82007 (307) 635-6827 (ph) (307) 635-2713 (fax)
- 428 Alan Road Powell, WY 82435 (307) 754-7170 (ph) (307) 754-7088 (fax)

- 520 Wilkes, Suite 13 Green River, WY 82935

(307) 875-4394 (ph)

(307) 875-4395 (fax)

\begin{tabular}{ll} 
Project: & Testing \\
\cline { 2 - 2 } Client: & USGS \\
\cline { 2 - 2 } Sample Type: & Bulk, Native Gravel \\
\cline { 2 - 2 } Sampled By: & Client
\end{tabular}

Project No.:

11919 RM

Date:

6-23-05

Sample Source:

Willow

\section{Sampled Date:}

T-84, T-85/

C127,C128

\begin{tabular}{cc} 
Bulk Specific Gravity: & 2.559 \\
& \\
Percent Absorption: & $2.1 \%$ \\
\hline
\end{tabular}

Dry Creek Pit \#1

\begin{tabular}{|c|c|c|c|}
\hline \multicolumn{4}{|c|}{$\begin{array}{c}\text { T-30/C136 } \\
\text { Sample Gradation }\end{array}$} \\
\hline \multirow{2}{*}{$\begin{array}{l}\text { Sieve } \\
\text { Size }\end{array}$} & \multirow{2}{*}{$\begin{array}{c}\text { Percent } \\
\text { Finer }\end{array}$} & \multicolumn{2}{|c|}{ Specification } \\
\hline & & Low & High \\
\hline $3 "$ & 100 & & \\
\hline $2 \frac{1}{2 \prime \prime}$ & 90 & & \\
\hline $2 "$ & 83 & & \\
\hline $11 / 2^{\prime \prime}$ & 62 & & \\
\hline 1" & 47 & & \\
\hline $3 / 4 "$ & 36 & & \\
\hline $1 / 2 "$ & 27 & & \\
\hline $3 / 8 "$ & 23 & & \\
\hline$\# 4$ & 16 & & \\
\hline \#8 & 13 & & \\
\hline$\# 10$ & & & \\
\hline \#16 & 11 & & \\
\hline \#30 & 8 & & \\
\hline$\# 40$ & & & \\
\hline \#50 & 4 & & \\
\hline \#100 & 2 & & \\
\hline \#200 & 1.6 & & \\
\hline
\end{tabular}

Additional Tests:

\section{grading: A $\%$ Loss, 500 revolutions 26.8}

T-99/D698 Standard Proctor: Method:

Max Density: pcf

Opt. Moisture $\%$

T-180/D1557 Modified Proctor: Method:

Max Density: pcf Opt. Moisture $\%$

T-19/C29 Unit Weight \& Percent Voids: Unit Wt: pcf $\%$ Voids:

T-21/C40 Organic Impurities in Fine Aggregate: Rating:

$\mathrm{T}-89, \mathrm{~T}-90$

D4318

Atterberg Limits:

LL: PL: PI:

D2419/T-176 Sand Equivalent:

D1883/T-193 CBR Value:
C88

Soundness by Sodium Sulfate:

\begin{tabular}{|c|c|}
\hline Sieve Size: & Weighted \% Loss: \\
\hline$-1.5 "-+0.75 "$ & 1.4 \\
\hline$-0.75^{\prime \prime}-+0.375$ & 1.1 \\
\hline$-0.375-\# 4$ & 0.4 \\
\hline & \\
\hline & \\
\hline
\end{tabular}

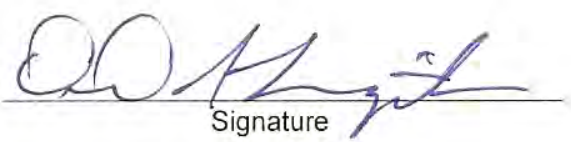

F:111919111919 Sheer Pit \#1 AGGREGATE SUMM SHEET.doc 


\section{AGGREGATE LABORATORY TEST RESULTS SUMMARY SHEET}

\ 124 E. Main Street Riverton, WY 82501 (307) 856-8136 (ph) (307) 856-3851 (fax)

口 1120 E. "C" Street Casper, WY 82601 (307) 577-0806 (ph) (307) 472-4402 (fax)
- 350 Parsley Boulevard Cheyenne, WY 82007 (307) 635-6827 (ph) (307) 635-2713 (fax)
口 428 Alan Road Powell, WY 82435

(307) 754-7170 (ph)

(307) 754-7088 (fax)
口 520 Wilkes, Suite 13 Green River, WY 82935

(307) 875-4394 (ph)

(307) 875-4395 (fax)

\begin{tabular}{ll} 
Project: & Testing \\
\cline { 2 - 2 } Client: & USGS \\
\cline { 2 - 2 } Sample Type: & Bulk, Native Gravel \\
Sampled By: & Client
\end{tabular}

Project No.: $\quad 11919$ RM

Date:

Sample Source:

5-20-05

Winkleman Dome, Pit 1,

Sampled Date:

\#1
T-84,T-85/

C127,C128

\begin{tabular}{cc} 
Bulk Specific Gravity: & 2.553 \\
Percent Absorption: & $1.7 \%$ \\
\hline
\end{tabular}

\begin{tabular}{|c|c|c|c|}
\hline \multicolumn{4}{|c|}{ T-30/C136 } \\
\multicolumn{4}{|c|}{ Sample Gradation } \\
\hline Sieve & Percent & Specification \\
\hline Size & Finer & Low & High \\
\hline $3 "$ & & & \\
$21 / 2 "$ & 90 & & \\
$2 "$ & 82 & \\
$11 / 2 "$ & 70 & \\
$1 "$ & 55 & \\
$3 / 4 "$ & 47 & \\
$1 / 2 "$ & 37 & \\
$3 / 8 "$ & 32 & \\
$\# 4$ & 25 & \\
$\# 8$ & 22 & \\
$\# 10$ & & \\
$\# 16$ & 20 & \\
$\# 30$ & 14 & \\
$\# 40$ & & \\
$\# 50$ & 7 & \\
$\# 100$ & 3 & \\
$\# 200$ & 1.4 & \\
\hline
\end{tabular}

Additional Tests:

\section{$\%$ Loss, 500 revolutions \\ 23.6}

T-99/D698 Standard Proctor: $\quad$ Method:

Max Density: pcf

Opt. Moisture $\%$

T-180/D1557 Modified Proctor: Method:

Max Density: pcf

Opt. Moisture $\%$

T-19/C29 Unit Weight \& Percent Voids: Unit Wt: pcf \% Voids:

$\mathrm{T}-21 / \mathrm{C} 40$ Organic Impurities in Fine Aggregate: Rating:

$\mathrm{T}-89, \mathrm{~T}-90$

D4318

Atterberg Limits:

LL:

PL:

$\mathrm{Pl}$ :

D2419/T-176 Sand Equivalent:

D1883/T-193 CBR Value:

Note: Moderate to heavy caliche deposits on aggregate

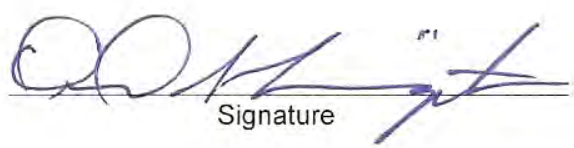

\begin{tabular}{|c|c|}
\hline \multicolumn{2}{|c|}{ C88 } \\
Soundness by Sodium Sulfate: \\
\hline Sieve Size: & Weighted \% Loss: \\
\hline$-1.5 "-+0.75 "$ & 0.4 \\
\hline$-0.75 "-+0.375$ & 0.4 \\
\hline$-0.375-\# 4$ & 0.5 \\
\hline & \\
\hline & \\
\hline
\end{tabular}

F:111919l11919 Kane Draw Site \#1 AGGREGATE SUMM SHEET doc 


\section{AGGREGATE LABORATORY TEST RESULTS SUMMARY SHEET}

124 E Main Street Riverton, WY 82501 (307) 856-8136 (ph) (307) 856-3851 (fax)

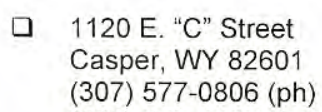
(307) 577-0806 (ph) (307) 472-4402 (fax)
- 350 Parsley Boulevard Cheyenne, WY 82007 (307) 635-6827 (ph) (307) 635-2713 (fax)
- 428 Alan Road Powell, WY 82435 (307) 754-7170 (ph) (307) 754-7088 (fax)

- 520 Wilkes, Suite 13 Green River, WY 82935

(307) 875-4394 (ph)

(307) 875-4395 (fax)

\begin{tabular}{ll} 
Project: & Testing \\
\cline { 2 - 2 } Client: & USGS
\end{tabular}

Sample Type: Bulk, Native Gravel

Sampled By:
Project No.:

Date:

Sample Source:

Sampled Date:
T-84, T-85/

C127,C128 Bulk Specific Gravity: 2.525

Percent Absorption:

T-96/C131 Percent Loss by L.A. Abrasion Machine $\%$ Loss, 100 revolutions

grading: A $\%$ Loss, 500 revolutions 24.8

T-99/D698 Standard Proctor: Method:

Max Density: pcf

Opt. Moisture $\%$

T-180/D1557 Modified Proctor: Method:

Max Density: pcf Opt. Moisture $\%$

T-19/C29 Unit Weight \& Percent Voids: Unit Wt: pcf \% Voids:

$\mathrm{T}-21 / \mathrm{C} 40$ Organic Impurities in Fine Aggregate: Rating:

$\mathrm{T}-89, \mathrm{~T}-90$

D4318

Atterberg Limits:

$\mathrm{LL}:$

PL:

PI:

D2419/T-176 Sand Equivalent:

D1883/T-193 CBR Value:

Additional Tests:

Note: Moderate to heavy caliche deposits on aggregate

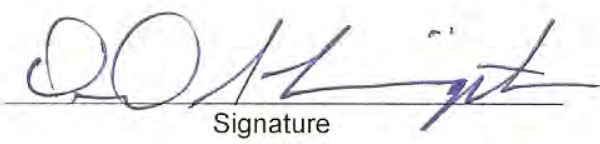

11919 RM

$5-20-05$

Winkleman Dome, Pit 2,

\#1

\begin{tabular}{|c|c|c|c|}
\hline \multicolumn{4}{|c|}{ T-30/C136 } \\
\multicolumn{4}{|c|}{ Sample Gradation } \\
\hline Sieve & Percent & Specification \\
\hline Size & Finer & Low & High \\
\hline $3 "$ & & & \\
2 1/2" $^{\prime \prime}$ & 92 & & \\
$2 "$ & 81 & & \\
$11 / 2 "$ & 74 & \\
$1 "$ & 62 & \\
$3 / 4 "$ & 54 & \\
$1 / 2 "$ & 45 & \\
$3 / 8 "$ & 41 & \\
$\# 4$ & 34 & \\
$\# 8$ & 32 & \\
$\# 10$ & & \\
$\# 16$ & 28 & \\
$\# 30$ & 18 & \\
$\# 40$ & & \\
$\# 50$ & 7 & \\
$\# 100$ & 3 & \\
\#200 & 1.7 & \\
\end{tabular}

$\mathrm{C} 88$

Soundness by Sodium Sulfate:

\begin{tabular}{|c|c|}
\hline Sieve Size: & Weighted \% Loss: \\
\hline$-1.5^{\prime \prime}-+0.75^{\prime \prime}$ & 0.2 \\
\hline$-0.75^{\prime \prime}-+0.375$ & 0.6 \\
\hline$-0.375-\# 4$ & 0.5 \\
\hline & \\
\hline & \\
\hline
\end{tabular}




\section{AGGREGATE LABORATORY TEST RESULTS SUMMARY SHEET}

ه 124 E. Main Street Riverton, WY 82501 (307) 856-8136 (ph) (307) 856-3851 (fax)
1120 E. "C" Street Casper, WY 82601 (307) 577-0806 (ph) (307) 472-4402 (fax)
350 Parsley Boulevard Cheyenne, WY 82007 (307) 635-6827 (ph) (307) 635-2713 (fax)
- 428 Alan Road Powell, WY 82435 (307) 754-7170 (ph) (307) 754-7088 (fax)

520 Wilkes, Suite 13 Green River, WY 82935

(307) 875-4394 (ph)

(307) 875-4395 (fax)

\begin{tabular}{ll} 
Project: & Testing \\
\cline { 2 - 2 } Client: & USGS \\
Sample Type: & Bulk, Crushed Aggregate \\
\cline { 2 - 2 } Sampled By: & Client
\end{tabular}

Project No.:

Date:

11919 RM

5-20-05

Sample Source: Stockpile

Winkleman Dome, Pit 2,

Sampled Date:
$\mathrm{T}-84, \mathrm{~T}-85 /$

C127,C128 Bulk Specific Gravity:

2.540

Percent Absorption $1.7 \%$

T-96/C131 Percent Loss by L.A. Abrasion Machine $\%$ Loss, 100 revolutions

grading: A $\%$ Loss, 500 revolutions 28.9

T-99/D698 Standard Proctor: $\quad$ Method:

Max Density: pcf

Opt. Moisture $\%$

T-180/D1557 Modified Proctor: Method:

Max Density: pcf Opt. Moisture $\%$

T-19/C29 Unit Weight \& Percent Voids: Unit Wt: pef \% Voids:

$\mathrm{T}-21 / \mathrm{C} 40$ Organic Impurities in Fine Aggregate: Rating:

$\mathrm{T}-89, \mathrm{~T}-90$

D4318

Atterberg Limits:

LL:

PL: PI:

D2419/T-176

D1883/T-193

Sand Equivalent:

CBR Value:

Additional Tests:

\begin{tabular}{|c|c|c|c|}
\hline \multicolumn{4}{|c|}{ T-30/C136 } \\
\multicolumn{3}{|c|}{ Sample Gradation } \\
\hline Sieve & Percent & Specification \\
\cline { 3 - 4 } Size & Finer & Low & High \\
\hline 3" & & & \\
$21 / 2 "$ & & \\
$2 "$ & & \\
$11 / 2 "$ & & \\
$1 "$ & 98 & \\
$3 / 4 "$ & 85 & \\
$1 / 2 "$ & 67 & \\
$3 / 8 "$ & 59 & \\
$\# 4$ & 44 & \\
$\# 8$ & 39 & \\
$\# 10$ & & \\
$\# 16$ & 34 & \\
$\# 30$ & 25 & \\
$\# 40$ & & \\
$\# 50$ & 17 & \\
$\# 100$ & 12 & \\
$\# 200$ & 8.6 & \\
\end{tabular}

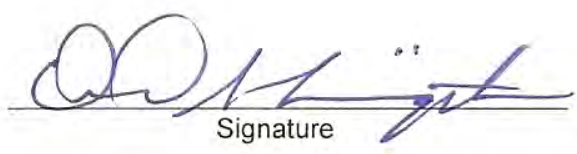

$\mathrm{C} 88$

Soundness by Sodium Sulfate:

\begin{tabular}{|c|c|}
\hline Sieve Size: & Weighted \% Loss: \\
\hline$-1.5 "-+0.75 "$ & \\
\hline$-0.75 "-+0.375$ & 0.9 \\
\hline$-0.375-\# 4$ & 0.7 \\
\hline & \\
\hline & \\
\hline
\end{tabular}




\section{Appendix D-Digital GIS Dataset of Sand and Gravel Deposits on the Wind River Indian Reservation, Wyoming}




\section{INTRODUCTION}

The set of six digital data files in this report form an ESRI ${ }^{\text {TM }}$ polygon Shapefile, which can be used in Geographic Information System (GIS) software to plot maps of sand and gravel deposits within the Wind River Indian Reservation, Wyoming.

The gravel deposits outlined by this shapefile (609 polygons) were adapted and digitized from two geologic maps of the Wind River Indian Reservation:

Plate 1, scale 1:63,360, of Morris, D.A., Hackett, O.M., Vanlier, K.E., and Moulder, E.A., 1959, Ground-water resources of Riverton Irrigation Project Area, Wyoming: U.S. Geological Survey Water-Supply Paper 1375, 205 p., 6 plates.

Plate 2, scale 1:125,000, of McGreevy, L.J., Hodson, W.G., and Rucker, S.J., IV, 1969, Ground-water resources of the Wind River Indian Reservation, Wyoming: U.S. Geological Survey WaterSupply Paper 1576-I, 145 p., 3 plates.

Most of the shapefile polygons (549 of 609) are sand and gravel deposits of terraces of the ancient Wind River and its tributaries. The terraces were deposited as the rivers migrated across and cut downward into the Wind River Basin over the last 1,700,000 years (Chadwick, O.A., Hall, R.D., and Phillips, F.M., 1997, Chronology of Pleistocene glacial advances in the central Rocky Mountains: Geological Society of America Bulletin, v. 109, no. 11, p. 1443-1452). The geology and characteristics of these terrace deposits are described in this report. Deposits of sand and gravel (alluvium) within the active channels and floodplains of the modern rivers and streams were not included in the shapefile.

Some of the sand and gravel deposits (60 of 609 polygons) in the shapefile were interpreted by this study to be alluvial fan deposits. Alluvial fans are gently sloping, apron-shaped masses (fans) of rock debris and sediment (alluvium) that form along the base of mountain slopes. Alluvial fans typically form where a mountain stream exits a narrow mountain valley and deposits its water-laden material onto a broad valley or plain. Alluvial fan deposits are preserved along the eastern base of the Wind River Range and the southern base of the Owl Creek Mountains.

\section{SHAPEFILE CREATION}

The geologic maps of Morris and others (1959, plate 1) and McGreevy and others (1969, plate 2) were digitally scanned and georeferenced. The resulting digital geologic maps were superimposed upon digital USGS 71/2-minute (scale 1:24,000) topographic quadrangles. Using the GIS software program

ArcMap (ESRI ), the mapped sand and gravel deposits of Morris and others (1959) and McGreevy and others (1969) were hand digitized on-screen approximately one square mile at a time at a screen-view scale of 1:12,000. The geologic mapping of Morris and others (1959) and McGreevy and others (1969) was adjusted to match the topography (as viewed at a scale of 1:12,0000). The digital mapping shown in the shapefile must be considered approximately located because no field inspections were made.

Where the geologic maps overlap, the geologic mapping of Morris and others (1959) was preferentially used because their mapping is at a larger, more detailed scale and includes information on 
river terrace level. Ten polygons were added by the authors, which are sand and gravel deposits that are not shown on the maps of Morris and others (1959) or McGreevy and others (1969).

A Universal Transverse Mercator map projection with map parameters of NAD 1927, UTM Zone $12 \mathrm{~N}$, and in meters, was used. The datum information is supplied by the data file gravels.prj

\section{DATA FIELDS IN THE SHAPEFILE}

Four data fields were attributed in each of the 609 polygons in the gravels shapefile, as follows:

\begin{tabular}{|c|c|c|}
\hline Data field & Entries & Description \\
\hline 'FID' & '0’ to'608' & Unique number used to identify each polygon. \\
\hline \multirow[t]{5}{*}{ 'Landform' } & 'fan' & Interpreted as an alluvial fan deposit $(n=60)$. \\
\hline & 'terrace' & Interpreted as an ancient river terrace ( $n=549)$. \\
\hline & 'Morris and others (1959)' & $\begin{array}{l}\text { Polygon adapted from the geologic map of Morris and } \\
\text { others (1959) }(n=305) \text {. }\end{array}$ \\
\hline & McGreevy and others (1969)' & $\begin{array}{l}\text { Polygon adapted from the geologic map of McGreevy and } \\
\text { others (1969) }(n=294) \text {. }\end{array}$ \\
\hline & 'not mapped' & $\begin{array}{l}\text { Polygon added by this study; previously unmapped } \\
(n=10) .\end{array}$ \\
\hline \multirow[t]{16}{*}{ 'Map_unit' } & ‘Qf’ & $\begin{array}{l}\text { Alluvial fan deposit ( } n=67) \text {; as interpreted by this } \\
\text { study based on the slope of their surface and their } \\
\text { close proximity to a mountain front. Mapped as } \\
\text { 'Qt' by McGreevy and others (1969). }\end{array}$ \\
\hline & 'Qt' & $\begin{array}{l}\text { "Terrace and pediment deposits", as mapped by } \\
\text { McGreevy and others (1969) }(n=237) \text {. }\end{array}$ \\
\hline & 'Qtu' & $\begin{array}{l}\text { River terrace of uncertain terrace level, mapped by } \\
\text { Morris and others (1959) }(n=8) \text {. }\end{array}$ \\
\hline & 'Qt1' & River terrace level 1 of Morris and others (1959) n=3). \\
\hline & 'Qt2' & River terrace level 2 of Morris and others (1959) $(n=57)$. \\
\hline & 'Qt3' & River terrace level 3 of Morris and others (1959) $(n=54)$. \\
\hline & ‘Qt4’ & River terrace level 4 of Morris and others (1959) $n=11$ ). \\
\hline & 'Qt5’ & River terrace level 5 of Morris and others (1959) $(n=68)$. \\
\hline & 'Qt6’ & River terrace level 6 of Morris and others (1959) $(n=33)$. \\
\hline & ‘Qt7’ & River terrace level 7 of Morris and others (1959) $(n=9)$. \\
\hline & ‘Qt8' & River terrace level 8 of Morris and others (1959) $(n=30)$. \\
\hline & 'Qt9' & River terrace level 9 of Morris and others (1959) $(n=10)$. \\
\hline & ‘Qt10’ & River terrace level 10 of Morris and others (1959) (n=14). \\
\hline & ‘Qt11' & River terrace level 11 of Morris and others (1959) $\quad(n=3)$. \\
\hline & 'Qt12' & River terrace level 12 of Morris and others (1959) $\quad(n=1)$. \\
\hline & 'Qt13' & River terrace level 13 of Morris and others (1959) $\quad(n=4)$. \\
\hline
\end{tabular}

